\title{
Single or double-level anterior interbody fusion techniques for cervical degenerative disc disease (Review)
}

Jacobs W, Willems PC, van Limbeek J, Bartels R, Pavlov P, Anderson PG, Oner FC

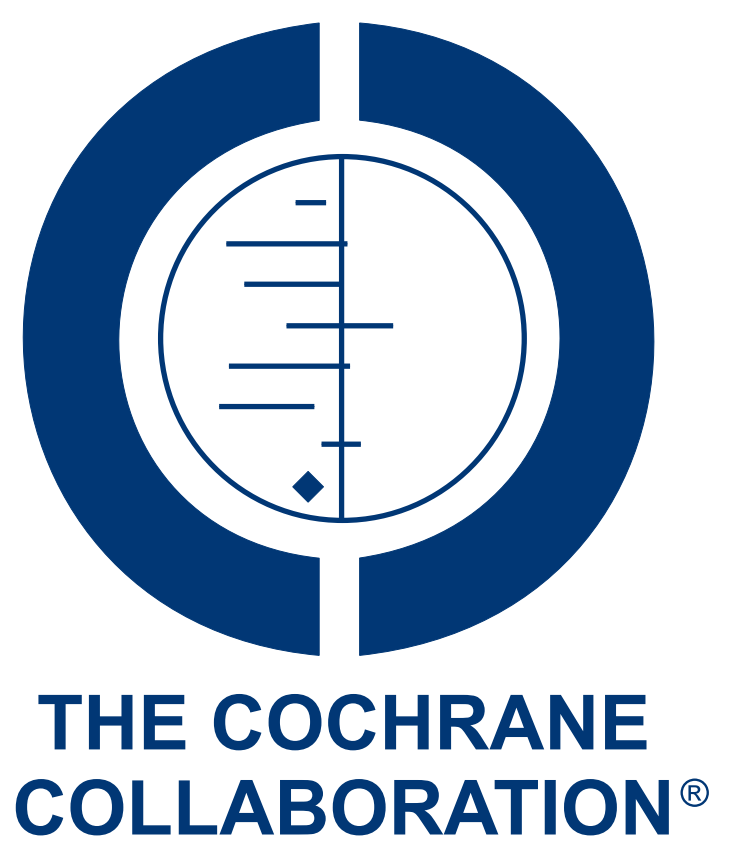

This is a reprint of a Cochrane review, prepared and maintained by The Cochrane Collaboration and published in The Cochrane Library 2011, Issue 3

http://www.thecochranelibrary.com

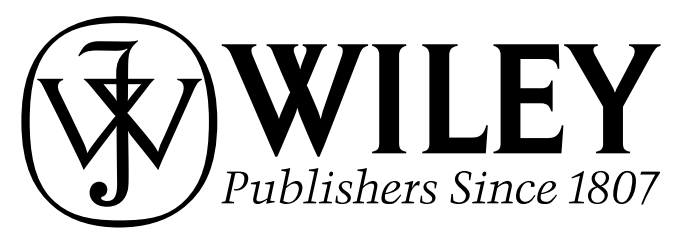

Single or double-level anterior interbody fusion techniques for cervical degenerative disc disease (Review)

Copyright (C) 201 I The Cochrane Collaboration. Published by John Wiley \& Sons, Ltd. 
TABLE OF CONTENTS

HEADER . . . . . . . . . . . . . . . . . . . . . . . . . . . . . . . . 1

ABSTRACT .. . . . . . . . . . . . . . . . . . . . . . . . . . . . . . . . . . . . . . . . . . . . . . . . .

PLAIN LANGUAGE SUMMARY . . . . . . . . . . . . . . . . . . . . . . . . . . . . . . . . . . . $\quad$. 2

BACKGROUND . . . . . . . . . . . . . . . . . . . . . . . . . . . . . . . . . . . . . 3

OBJECTIVES . . . . . . . . . . . . . . . . . . . . . . . . . . . . . . . . . . . . . . 4

METHODS . . . . . . . . . . . . . . . . . . . . . . . . . . . . . . . . . . . 4

RESUlTS . . . . . . . . . . . . . . . . . . . . . . . . . . . . . . . . . . . . . . . 6

Figure 1. . . . . . . . . . . . . . . . . . . . . . . . . . . . . . . . . . . . . . 8

Figure 2. . . . . . . . . . . . . . . . . . . . . . . . . . . . . . . . . . . . . . 10

Figure 3. . . . . . . . . . . . . . . . . . . . . . . . . . . . . . . . . . . . . . 11

Figure $4 . \quad$. . . . . . . . . . . . . . . . . . . . . . . . . . . . . . . . . . . . . 13

Figure 5. . . . . . . . . . . . . . . . . . . . . . . . . . . . . . . . . . . . . . 16

DISCUSSION . . . . . . . . . . . . . . . . . . . . . . . . . . . . . . . . . . . . . 18

AUTHORS' CONCLUSIONS . . . . . . . . . . . . . . . . . . . . . . . . . . . . . . . . . 20

ACKNOWLEDGEMENTS . . . . . . . . . . . . . . . . . . . . . . . . . . . . . . . . . . . . . . . . . . 20

REFERENCES . . . . . . . . . . . . . . . . . . . . . . . . . . . . . . . . . . . . . 20

CHARACTERISTICS OF STUDIES . . . . . . . . . . . . . . . . . . . . . . . . . . . . . . . . . . . . . . . 25

DATA AND ANALYSES . . . . . . . . . . . . . . . . . . . . . . . . . . . . . . . . . . . . . . . . . . . 66

Analysis 1.1. Comparison 1 Discectomy alone vs human bone graft, Outcome 1 Hospital stay. . . . . . . . . . . 70

Analysis 1.2. Comparison 1 Discectomy alone vs human bone graft, Outcome 2 Operation time. . . . . . . . . 71

Analysis 1.3. Comparison 1 Discectomy alone vs human bone graft, Outcome 3 Blood loss. . . . . . . . . . . . 71

Analysis 1.4. Comparison 1 Discectomy alone vs human bone graft, Outcome 4 Pain not relieved at 5 weeks. . . . $\quad 72$

Analysis 1.5. Comparison 1 Discectomy alone vs human bone graft, Outcome 5 Odom's criteria. . . . . . . . . $\quad$. 72

Analysis 1.6. Comparison 1 Discectomy alone vs human bone graft, Outcome 6 Not Returned to work at 5 weeks. $\quad . \quad 73$

Analysis 1.7. Comparison 1 Discectomy alone vs human bone graft, Outcome 7 Not Returned to work at 10 weeks. 73

Analysis 1.8. Comparison 1 Discectomy alone vs human bone graft, Outcome 8 No Fusion. . . . . . . . . . . . 74

Analysis 1.9. Comparison 1 Discectomy alone vs human bone graft, Outcome 9 Alignment. . . . . . . . . . . . 75

Analysis 2.1. Comparison 2 Discectomy alone vs cage or cement, Outcome 1 Operation time. . . . . . . . . . . 75

Analysis 2.2. Comparison 2 Discectomy alone vs cage or cement, Outcome 2 Blood loss. . . . . . . . . . . . . . . 76

Analysis 2.3. Comparison 2 Discectomy alone vs cage or cement, Outcome 3 Length of stay. . . . . . . . . . . . . 77

Analysis 2.4. Comparison 2 Discectomy alone vs cage or cement, Outcome 4 Recovery. . . . . . . . . . . . . . . . 78

Analysis 2.5. Comparison 2 Discectomy alone vs cage or cement, Outcome 5 Neck pain not relieved at 6 weeks. $\quad . \quad$. 78

Analysis 2.6. Comparison 2 Discectomy alone vs cage or cement, Outcome 6 Neck pain not relieved at 2 years. $\quad . \quad$. 79

Analysis 2.7. Comparison 2 Discectomy alone vs cage or cement, Outcome 7 VAS Arm pain 24 months. . . . . $\quad 79$

Analysis 2.8. Comparison 2 Discectomy alone vs cage or cement, Outcome 8 VAS Neck pain 24 months. . . . . $\quad$. 80

Analysis 2.9. Comparison 2 Discectomy alone vs cage or cement, Outcome 9 NASS pain 24 months. . . . . . . . $\quad$ 80

Analysis 2.10. Comparison 2 Discectomy alone vs cage or cement, Outcome 10 NASS neurology 24 months. . . . 81

Analysis 2.11. Comparison 2 Discectomy alone vs cage or cement, Outcome 11 No Fusion. . . . . . . . . . . . . . $\quad 81$

Analysis 3.1. Comparison 3 Discectomy alone vs human bone graft with plates, Outcome 1 VAS Arm pain. $\quad$. $\quad . \quad$. 83

Analysis 3.2. Comparison 3 Discectomy alone vs human bone graft with plates, Outcome 2 VAS neck pain. $\quad . \quad$. $\quad 83$

Analysis 3.3. Comparison 3 Discectomy alone vs human bone graft with plates, Outcome 3 Disc height. . . . $\quad$. 84

Analysis 3.4. Comparison 3 Discectomy alone vs human bone graft with plates, Outcome 4 Odoms criteria. . . . $\quad 84$

Analysis 3.5. Comparison 3 Discectomy alone vs human bone graft with plates, Outcome 5 Fusion. . . . . . . . $\quad$. 85

Analysis 4.1. Comparison 4 Iliac crest autograft vs human allograft or bone substitute, Outcome 1 headache. . . . $\quad . \quad 85$

Analysis 4.2. Comparison 4 Iliac crest autograft vs human allograft or bone substitute, Outcome 2 Sensory function. 86

Analysis 4.3. Comparison 4 Iliac crest autograft vs human allograft or bone substitute, Outcome 3 Muscle power. $\quad . \quad 86$

Analysis 4.4. Comparison 4 Iliac crest autograft vs human allograft or bone substitute, Outcome 4 Odoms criteria. $\quad . \quad 87$

Analysis 5.1. Comparison 5 Iliac crest autograft vs cage, Outcome 1 Operation time. . . . . . . . . . . . . . . . $\quad$. 87

Analysis 5.2. Comparison 5 Iliac crest autograft vs cage, Outcome 2 Blood loss. . . . . . . . . . . . . . . . . . . . . 88

Analysis 5.3. Comparison 5 Iliac crest autograft vs cage, Outcome 3 Hospital stay. . . . . . . . . . . . . . . . . . $\quad 88$

Analysis 5.4. Comparison 5 Iliac crest autograft vs cage, Outcome 4 VAS Neck Pain. ～. . . . . . . . . . . . . . $\quad$. 89

Single or double-level anterior interbody fusion techniques for cervical degenerative disc disease (Review)

Copyright ( 201 I The Cochrane Collaboration. Published by John Wiley \& Sons, Ltd. 
Analysis 5.5. Comparison 5 Iliac crest autograft vs cage, Outcome 5 VAS Arm pain. . . . . . . . . . . . . . . . $\quad$. 89

Analysis 5.6. Comparison 5 Iliac crest autograft vs cage, Outcome 6 Neck Disability Index (NDI). . . . . . . . $\quad .90$

Analysis 5.7. Comparison 5 Iliac crest autograft vs cage, Outcome 7 JOA. . . . . . . . . . . . . . . . . . . . $\quad 90$

Analysis 5.8. Comparison 5 Iliac crest autograft vs cage, Outcome 8 Odom's criteria. . . . . . . . . . . . . . . . 91

Analysis 5.9. Comparison 5 Iliac crest autograft vs cage, Outcome 9 SF-36 Physical. . . . . . . . . . . . . . . . . 91

Analysis 5.10. Comparison 5 Iliac crest autograft vs cage, Outcome 10 SF-36 Mental. . . . . . . . . . . . . . 92

Analysis 5.11. Comparison 5 Iliac crest autograft vs cage, Outcome 11 Satisfaction. . . . . . . . . . . . . . . . . . 92

Analysis 5.12. Comparison 5 Iliac crest autograft vs cage, Outcome 12 Foraminal height. . . . . . . . . . . . . . . 93

Analysis 5.13. Comparison 5 Iliac crest autograft vs cage, Outcome 13 Interspace height. . . . . . . . . . . . . . . 93

Analysis 5.14. Comparison 5 Iliac crest autograft vs cage, Outcome 14 Cobb angle. . . . . . . . . . . . . . . . . . 94

Analysis 5.15. Comparison 5 Iliac crest autograft vs cage, Outcome 15 No Fusion. . . . . . . . . . . . . . . . . . 94

Analysis 6.1. Comparison 6 Iliac crest autograft vs iliac crest autograft with plates, Outcome 1 Clinical outcome. . . 95

Analysis 6.2. Comparison 6 Iliac crest autograft vs iliac crest autograft with plates, Outcome 2 No Fusion. . . . . . 96

Analysis 7.1. Comparison 7 Different types of autograft, Outcome 1 Fusion. . . . . . . . . . . . . . . . . . . . . 96

Analysis 9.1. Comparison 9 Other comparisons between different types of instrumentation, Outcome 1 Odom's criteria. 97

Analysis 10.1. Comparison 10 PMMA vs cage, Outcome 1 Operation time. . . . . . . . . . . . . . . . . . . . . . 97

Analysis 10.2. Comparison 10 PMMA vs cage, Outcome 2 Odoms criteria. . . . . . . . . . . . . . . . . . . . . 98

Analysis 10.3. Comparison 10 PMMA vs cage, Outcome 3 No Fusion. . . . . . . . . . . . . . . . . . . . . . . 98

Analysis 11.1. Comparison 11 Cage vs cage and plate, Outcome 1 Neck pain. . . . . . . . . . . . . . . . . . . . . 99

Analysis 11.2. Comparison 11 Cage vs cage and plate, Outcome 2 Arm pain. . . . . . . . . . . . . . . . . . . . 99

Analysis 11.3. Comparison 11 Cage vs cage and plate, Outcome 3 JOA. . . . . . . . . . . . . . . . . . . . . . 100

Analysis 11.4. Comparison 11 Cage vs cage and plate, Outcome 4 Segmental lordosis. . . . . . . . . . . . . . . 100

Analysis 12.1. Comparison 12 Complications, Outcome 1 complications. . . . . . . . . . . . . . . . . . . . 101

ADDITIONAL TABLES . . . . . . . . . . . . . . . . . . . . . . . . . . . . . . . . . . . . . . 104

APPENDICES . . . . . . . . . . . . . . . . . . . . . . . . . . . . . . . . . . . . . . 106

FEEDBACK . . . . . . . . . . . . . . . . . . . . . . . . . . . . . . . . . . . . . . 111

WHAT'S NEW . . . . . . . . . . . . . . . . . . . . . . . . . . . . . . . . . . . . . 113

HISTORY . . . . . . . . . . . . . . . . . . . . . . . . . . . . . . . . . . . . . . . . 113

CONTRIBUTIONS OF AUTHORS . . . . . . . . . . . . . . . . . . . . . . . . . . . . . . . . . . . . . . . 114

DECLARATIONS OF INTEREST . . . . . . . . . . . . . . . . . . . . . . . . . . . . . . . . . . 114

SOURCES OF SUPPORT . . . . . . . . . . . . . . . . . . . . . . . . . . . . . . . . . . . . . . . . . . . . . . .

DIFFERENCES BETWEEN PROTOCOL AND REVIEW . . . . . . . . . . . . . . . . . . . . . 115

INDEX TERMS . . . . . . . . . . . . . . . . . . . . . . . . . . . . . . . . . . . . . . . . . . . . 115

Single or double-level anterior interbody fusion techniques for cervical degenerative disc disease (Review) 


\section{Single or double-level anterior interbody fusion techniques for cervical degenerative disc disease}

Wilco Jacobs ${ }^{1}$, Paul C Willems ${ }^{2}$, Jacques van Limbeek ${ }^{3}$, Ronald Bartels ${ }^{4}$, Paul Pavlov ${ }^{5}$, Patricia G Anderson ${ }^{3}$, F Cumhur Oner ${ }^{6}$

${ }^{1}$ Department of Neurosurgery, Leiden University Medical Center, Leiden, Netherlands. ${ }^{2}$ Department of Orthopaedics, Maastricht University Medical Centre, Maastricht, Netherlands. ${ }^{3}$ Department of Research, Development and Education, Sint Maartenskliniek, Nijmegen, Netherlands. ${ }^{4}$ Department of Neurosurgery, Radboud University Nijmegen Medical Center, Nijmegen, Netherlands. ${ }^{5}$ Department of Orthopedics, Sint Maartenskliniek, Nijmegen, Netherlands. ${ }^{6}$ Department of Orthopedics, University Medical Center Utrecht, Utrecht, Netherlands

Contact address: Wilco Jacobs, Department of Neurosurgery, Leiden University Medical Center, PO Box 9600, Leiden, 2300 RC, Netherlands.w.c.h.jacobs@lumc.nl.

Editorial group: Cochrane Back Group.

Publication status and date: Edited (no change to conclusions), published in Issue 3, 2011.

Review content assessed as up-to-date: 14 November 2009.

Citation: Jacobs W, Willems PC, van Limbeek J, Bartels R, Pavlov P, Anderson PG, Oner FC. Single or double-level anterior interbody fusion techniques for cervical degenerative disc disease. Cochrane Database of Systematic Reviews 2011, Issue 1. Art. No.: CD004958. DOI: 10.1002/14651858.CD004958.pub2.

Copyright @ 2011 The Cochrane Collaboration. Published by John Wiley \& Sons, Ltd.

A B S T R A C T

\section{Background}

The number of surgical techniques for decompression and solid interbody fusion as treatment for cervical spondylosis has increased rapidly, but the rationale for the choice between different techniques remains unclear.

\section{Objectives}

To determine which technique of anterior interbody fusion gives the best clinical and radiological outcomes in patients with single- or double-level degenerative disc disease of the cervical spine.

\section{Search methods}

We searched CENTRAL (The Cochrane Library 2009, issue 1), MEDLINE (1966 to May 2009), EMBASE (1980 to May 2009), BIOSIS (2004 to May 2009), and references of selected articles.

\section{Selection criteria}

Randomised comparative studies that compared anterior cervical decompression and interbody fusion techniques for participants with chronic degenerative disc disease.

Data collection and analysis

Two review authors independently assessed risk of bias using the Cochrane Back Review Group criteria. Data on demographics, intervention details and outcome measures were extracted onto a pre-tested data extraction form. 


\section{Main results}

Thirty-three small studies ( 2267 patients) compared different fusion techniques. The major treatments were discectomy alone, addition of an interbody fusion procedure (autograft, allograft, cement, or cage), and addition of anterior plates. Eight studies had a low risk of bias. Few studies reported on pain, therefore, at best, there was very low quality evidence of little or no difference in pain relief between the different techniques. We found moderate quality evidence for these secondary outcomes: no statistically significant difference in Odom's criteria between iliac crest autograft and a metal cage (6 studies, RR 1.11 (95\% CI 0.99 to1.24)); bone graft produced more effective fusion than discectomy alone (5 studies, RR 0.22 (95\% CI 0.17 to 0.48 )); no statistically significant difference in complication rates between discectomy alone and iliac crest autograft (7 studies, RR 1.56 (95\% CI 0.71 to 3.43)); and low quality evidence that iliac crest autograft results in better fusion than a cage (5 studies, RR 1.87 (95\% CI 1.10 to 3.17)); but more complications (7 studies, RR 0.33 (95\% CI 0.12 to 0.92$)$ ).

\section{Authors' conclusions}

When the working mechanism for pain relief and functional improvement is fusion of the motion segment, there is low quality evidence that iliac crest autograft appears to be the better technique. When ignoring fusion rates and looking at complication rates, a cage has a weak evidence base over iliac crest autograft, but not over discectomy alone. Future research should compare additional instrumentation such as screws, plates, and cages against discectomy with or without autograft.

\section{PLAIN LANGUAGE S UMMARY}

\section{Fusion techniques for degenerative disc disease}

Degenerative disc disease is part of the natural aging process of the human spine and can cause complications stemming from the nerve root or spinal cord. Degenerative disc disease of the spine can result in significant pain, instability, disturbances with the nerve roots or spinal cord, or a combination of symptoms. The cause of these symptoms comes from compression of the nerves.

When symptoms do not respond to conservative treatment, surgical treatment is considered. The goals of surgical treatment should be to remove pressure from the nerves, restore the alignment of the vertebrae and stabilize the spine. The common surgical technique to treat cervical disc disease is removal of the damaged disc with or without fusing the two adjacent vertebral bodies. Bone grafts (harvesting bone from other sites of the body) are usually used to stimulate the fusion process.

This review of 33 small studies (2267 participants) evaluated fusion techniques used to treat degenerative disc disease. The major treatments were discectomy (removal of the damaged disc) alone, addition of a fusion procedure (bone transplanted from another part of the body, cement, or cage), and addition of a plate.

None of the evidence from this systematic review indicates that one technique is better than another for clinically significant pain relief for patients with chronic cervical degenerative disc disease or disc herniation. The choice for a specific technique cannot be made on the most important aspect, pain relief, which was the primary outcome parameter in our review. There is moderate quality evidence that there was little or no difference in Odom's criteria (a tool that measures the success of the surgery at relieving the symptoms that were troublesome prior to the surgery) between those who received a bone transplant from the hip and a metal cage to help with fusion.

There is moderate quality evidence that the use of a bone graft (bone transplanted from another part of the body) is more effective than discectomy alone in achieving fusion. There is low quality evidence that transplanting bone from the iliac crest is more effective in achieving fusion than using a cage, while cages are more effective in preventing complications.

Further research is very likely to have an important impact on the results and our confidence in them. 


\section{B A C K G R O U N D}

Degenerative disc disease is part of the natural aging process of the human spine and can cause complaints stemming from the nerve root (radiculopathy) or spinal cord (myelopathy). Radiculopathy affects, on average, 83 in 100,000 patients each year (Radhakrishnan 1994) with a prevalence of 35 per 100 patients (Salemi 1996). Degenerative disc disease of the cervical spine can result in significant pain, instability, radiculopathy, myelopathy or a combination of symptoms (Grob 1998). The cause of these symptoms can be loss of disc space height, loss of foraminal area, disc bulging or protruding osteophytes causing neural compression. See Table 1 for definitions.

When symptoms are refractory to conservative treatment, surgical treatment is considered. The goals of surgical treatment should be decompression, restoration of alignment, and stability. Decompression involves removal of the soft disc or osteolytic structures from the compressed neural elements so they no longer impinge on the nerves. Restoration of alignment involves restoration of the disc space height and neural foraminal height as well as the normal angle between the vertebrae. Stability involves elimination of motion of the motion segment. Therefore, a fusion technique can be used, provided it incorporates a structural support to replace the disc, and that a stable fusion of the vertebrae is acquired. The treatment of degenerative disc disease can be divided into posterior procedures (entering through the back of the neck and spine), anterior procedures (entering through the front of the neck and spine) or a combination of these. The popularity of the anterior approach for discectomy and fusion has increased because this approach avoids exposure of the spinal canal (Fraser 1995) and results in less soft tissue damage. Structural support is provided by using an autograft or allograft bone with a cage filled with autologous bone graft or artificial bone and/or an anterior plate.

The common surgical technique to treat cervical degenerative disc disease is discectomy (removal of damaged disc) with or without fusing the two adjacent vertebral bodies. Discectomy without fusion will lead to a spontaneous fusion in $70 \%$ to $80 \%$ of the cases. Bone grafts are usually used for stimulating the fusion of the two vertebrae. These bone grafts are harvested from other sites in the body during surgery, usually from the iliac crest. The bone graft stimulates the bones in the spine to generate new bone, results in reliable rates of fusion, and generally maintains its structural integrity. The most frequently cited technique for anterior discectomy and fusion is the one described by Smith and Robinson (Emery 1994). This technique uses a left anterior approach, with a longitudinal incision along the anterior border of the sternocleidomastoid muscle. By dissecting the superficial cervical fascia and passing medially from the carotid sheath and laterally from the oesophagus and trachea, the anterior aspect of the cervical spine can be reached. After identification of the correct level, preferably on fluoroscopy, the anterior longitudinal ligament is explored and cut, then the disc is excised, leaving the anterior bony aspects in place. The endplate is removed from the cartilage to induce union (fusion) with the bone graft. The tricortical bone graft is harvested from the iliac crest and inserted into the disc space. The Smith and Robinson technique, as cited in the literature, can refer to either the discectomy procedure alone, or the additional fusion using an iliac crest autograft. Some modifications have been made to the original technique (Emery 1994). The Cloward technique (Cloward 1956) is used for discectomy and fusion with a round bone dowel taken from the iliac crest. In contrast to the Smith and Robinson technique, the anterior vertebral bone structure is drilled into the shape of the bone dowel. See Espine Website 2010 for a description of the procedure.

The harvesting from the iliac crest can be associated with shortand long-term morbidity in up to $22 \%$ of the cases (McConnel 2003). Most frequently reported problems include postoperative pain, wound hematoma, infection, pelvic fracture, nerve palsy, and chronic donor site pain that is reported by an average of $2.4 \%$ of the patients in studies that report this complication (McConnel 2003). In a study that specifically looked at donor site pain, no less than $90 \%$ of patients complained of donor site pain (Heneghan 2009). This donor site morbidity has fuelled the search for various forms of allograft materials as alternatives for cervical interbody fusion (Vaccaro 2003). Interbody cages provide initial stability, and by filling the disc space, require less structural bone graft. Despite its potential to yield outcomes similar to those of autograft bone, allograft is expensive to produce, incorporates more slowly, carries the potential risk of disease transmission and is not universally available. In addition, it is only osteo-conductive and does not contain the same osteo-inductive elements as autologous grafts. Examples are fibular allograft (Young 1993) and Surgibone® (Savolainen 1994). Anterior cervical plating can provide immediate stability to the segment of the spine to which it is applied, maintain spinal alignment, prevent graft dislodgement and collapse, enhance fusion rates, and eliminate the need for external immobilisation.

The choice of technique to be used should ideally be based on the best evidence available in the literature (Blettner 1999; Greenhalgh 1999; Offringa 1999). Apart from the last version of this review (Jacobs 2004) and a few in-depth narrative reviews (Floyd 2000; Theodore 2000; Whitecloud 1999; Wigfield 2001), we could not identify any systematic reviews on the anterior approach for cervical interbody fusion. The goal of this systematic review is to determine which technique of interbody fusion, using the anterior approach, gives the best clinical and radiological outcomes for patients with single or double-level degenerative disc diseases of the cervical spine.

This review updates and expands the original review (van Limbeek 2000) and subsequent Cochrane review (Jacobs 2004) comparing anterior cervical fusion options. This expansion of the review from the first publication reflects the availability of new trials comparing treatments for cervical degenerative disc disease. 


\section{O B J E C T I V E S}

The goal of this updated review was to determine which technique of anterior interbody fusion gives the best clinical and radiological outcomes in patients with single- or double-level degenerative disc disease of the cervical spine.

\section{METHODS}

\section{Criteria for considering studies for this review}

\section{Types of studies}

In search of the best treatment for cervical degenerative disc disease, we only included randomised controlled trials (RCTs). We excluded articles that used 'quasi' randomisation techniques such as alternate appointments or birth dates to assign patients to experimental groups.

\section{Types of participants}

We included trials that included patients scheduled for surgery for chronic degenerative disc disease at one or two cervical levels, or for chronic manifestation of disc herniation, where patients suffered from complaints for at least 12 weeks. We made no exclusions for age or gender of the populations, or type, location or duration of symptoms. Trials including patients with fractures, tumours or disorders at more than two levels were excluded.

\section{Types of interventions}

The interventions evaluated in the trials were single- or doublelevel anterior discectomies and interbody fusion compared with other anterior fusion techniques for cervical degenerative disc disease. Discectomy alone was regarded as a technique that most frequently results in spontaneous fusion and as such, was also included in this study. Cervical interbody fusion techniques often use some kind of bone graft with or without cages, and additional instrumentation such as plates, so were also included. Disc arthroplasty was excluded because by definition, it is not a fusion procedure and because it is already covered by the review protocol on cervical disc arthroplasty by Boselie 2010 .

\section{Types of outcome measures}

The outcome parameters in the studies were clinical, functional, or radiological. The primary outcome variable was pain. Below is an indication of the expected outcome measures, but we made no exclusions on the type of outcome measure. The minimal duration of follow-up was six months.

\section{Primary outcomes}

\section{Clinical outcome measures}

- Arm Pain

- Neck Pain

\section{Secondary outcomes}

\section{Clinical outcome measures}

- Dichotomised success (for example Odom's Criteria (4-level assessment of success of surgery in relieving pre-operative symptoms. Symptoms are not limited to pain, but also include other discomforts and sensations). We dichotomised the scale, combining "Excellent/Good" and "Moderate/Poor".

- Quality of Life (for example SF-36 (36-Item Short-Form Survey - quality of life))

- Disability (for example Neck Disability index)

- Motor function

- Sensory function

- Daily tasks

- Work status

\section{Radiological outcome measures}

- Kyphosis on normal lateral radiograph

- Mobility on flexion-extension radiographs

- Fusion

- Radiolucency

\section{Serious complications}

- Related deaths

- Re-operation related to primary surgery

- Incapacitating neurological damage (permanent or temporary), Horner syndrome (sympathic nerve damage)

- Pseudoarhrosis

- Hardware failure with clinical implication

- Postoperative deep infection

- Thrombosis

\section{Search methods for identification of studies}

\section{Electronic searches}

The Cochrane Back Review Group (CBRG) Trials Search Coordinator conducted the literature search and one reviewer (WJ) retrieved the references to be evaluated. The following databases were searched:

- CENTRAL (The Cochrane Library 2009, Issue 1) 
- MEDLINE (1966 to May 2009)

- EMBASE (1980 to May 2009)

- BIOSIS (2004 to May 2009), Including earlier Current contents till 2004 .

The search strategies were adapted for the different databases. We made no restrictions on language or date of publication. The search strategies are given in Appendix 3.

\section{Searching other resources}

We screened the references of the included studies, and with citation tracking, we searched references that cited the included articles.

\section{Data collection and analysis}

\section{Selection of studies}

Two review authors (WJ, PW) independently selected the trials from the list of titles and abstracts of identified references and met to reach consensus. For the last version of this review, the search and selection was performed by the two reviewers. For this update, the CBRG Trials Search Co-ordinator (RC) performed a pre-screening of the references and the final selection was performed by the two review authors. If relevance could not be ascertained on the basis of the abstract, the complete article was retrieved. When consensus could not be reached, a third reviewer (PA) was consulted to resolve the disagreement.

Articles were selected in two steps. In the first step, articles were excluded when it was apparent from either the title or abstract that the study did not meet the criteria mentioned in Criteria for considering studies for this review. In the second step, articles were excluded when it was apparent from a quick scan of the full text of the article that it failed to meet the same inclusion criteria. When the same population was described in more than one study, all studies were used, but the studies were grouped and analysed as one population. The reason for exclusion was documented for each reference.

\section{Data extraction and management}

Details of randomisation, blinding and exclusions from the analyses were recorded onto separate, pre-developed forms. From each study, basic information was gathered concerning authors (affiliation, sponsoring), methods (study design, sample size), patients (selection criteria and diagnoses, age, sex), treatments (instrumentation, bone and bone substitutes), and outcome variables with results. Data were extracted and entered into RevMan 5.0.22 by one author (WJ) and checked by another author (PW). Publications were managed with the aid of Reference Manager ${ }^{\circledR}$. In addition, relevant information was recorded pertaining to database source, reason for exclusion and consensus of authors.

\section{Assessment of risk of bias in included studies}

Risk of bias of RCTs was assessed with the 12 criteria recommended by the Cochrane Back Review Group (Furlan 2009). Criteria and operationalisation are given in Appendix 1. The items were scored with 'yes', 'no', or 'unsure'. Studies were categorized as having a "low risk of bias" when at least six of the 12 criteria were met and the study had no serious methodological flaws (randomisation and allocation concealment techniques were valid).

The risk of bias was assessed independently by two review authors (WJ, PW), who again met to reach consensus. As before, if consensus could not be reached, a third review author (PA) was consulted to resolve the disagreement.

The potential to pool results was dependent on the comparability of the individual studies, i.e. identical treatments and outcome measures were used, sufficient detail was given to describe the selection criteria and other external validity criteria.

\section{Measures of treatment effect}

For dichotomous outcomes, we calculated risk ratios (RR). For continuous outcomes, we calculated a mean difference (MD). For each outcome, a $95 \%$ confidence interval $(95 \% \mathrm{CI})$ was computed. We used a random-effects model in all our comparisons as differences between studies will always be present. Clinical relevance was assessed by the five questions recommended by Furlan 2009 (see Appendix 2). Clinically important change was evaluated against the guideline given by Ostelo 2008, where a minimal important change of 30\% for Visual Analogue Scale (VAS), Numerical Rating Scale (NRS), Roland Morris Disability Questionnaire (RDQ), Oswestry Disability Index (ODI), and Quebec Back Pain Disability Questionnaire (QBPQ) was proposed in consensus.

\section{Dealing with missing data}

Missing clinical data in trials were accepted when they were less than $20 \%$, otherwise, the trial was excluded from the specific analysis. Missing information about parameter variability was estimated from ranges if provided or estimated from comparable trials.

\section{Assessment of heterogeneity}

Heterogeneity between RCTs was first assessed clinically and then statistically. Clinical heterogeneity was evaluated for study design, (allocation concealment, outcome assessor blinding, patient blinding), patient characteristics (pain location, levels involved, age, gender), treatment characteristics (discectomy alone, use of cages, use of graft, different types of graft) variability. When studies were judged to be clinically homogeneous, homogeneity was also tested with a $\mathrm{I}^{2}$-test. 


\section{Data synthesis}

We pooled the results from individual studies when the studies were judged to be sufficiently homogeneous (Clinical and statistical).

The quality of evidence for all primary outcome parameters, regardless of quantitative analysis, was evaluated using the GRADE approach (GRADE Working Group 2004 - Atkins 2004) and GRADE Profiler software, version 3.2.2, 2004-2007). In short, the quality of evidence was judged with the following criteria (adapted from Furlan 2009 and Atkins 2004):

- $75 \%$ of studies have a low risk of bias (6 or more items met, including valid randomisation and treatment allocation techniques)

- Included studies have consistent findings

- Included population adequately reflects selection criteria of review

- Results are based on direct comparison

- Estimate of effect is sufficiently precise (confidence interval narrow and conclusive)

- Analysis is free of publication bias (more than $75 \%$ of studies contributing to analysis)

Depending on how many domains were met, the quality of evidence was judged to be 'High', 'Moderate', 'Low' or 'Very Low'. Important outcomes for which there were no trials were considered to have 'no evidence'. An outcome with only one trial was automatically low quality and if it also had a high ROB, it dropped to very low quality

High quality evidence = all domains met; further research is very unlikely to change our confidence in the estimate of effect.

Moderate quality evidence $=$ all but one domain met; further research is likely to have an important impact on our confidence in the estimate of effect and may change the estimate.

Low quality evidence $=$ all but two domains met; further research is very likely to have an important impact on our confidence in the estimate of effect and is likely to change the estimate.

Very low quality evidence $=$ all but three domains met; there is great uncertainty about the estimate of effect.

No evidence $=$ no RCTs were identified that addressed this outcome

The clinical relevance of the review results was assessed with the five questions given in Appendix 2. The results of this assessment were used to inform the discussion of the final results and conclusions. Statistical analyses were conducted using Review Manager (RevMan) software 5.0.22.

\section{Subgroup analysis and investigation of heterogeneity}

We had planned to complete subgroup analyses to assess the effects of age, gender, disease severity, one or two-level procedures, and length of follow-up time on the outcomes. However, sufficient data were not available.

\section{Sensitivity analysis}

We had planned to complete sensitivity analyses to assess the effect of risk of bias (high or low) on outcomes. The use of a funnel plot was planned to identify publication bias. However, sufficient data were not available.

\section{R E S U L T S}

\section{Description of studies}

See: Characteristics of included studies; Characteristics of excluded studies; Characteristics of studies awaiting classification.

The results of the search and selection are from the current update. The results from the current update are further presented and analysed in addition to the previous results. For search and selection methods of the previous version we refer to Appendix 4.

\section{Search}

Electronic searches of the databases identified 2129 references, minus duplicates: 225 from CENTRAL, 660 from MEDLINE, 1400 from EMBASE, 244 from Current Contents (till May 2009) and 293 from BIOSIS (2004 to May 2009). The Trials Search Co-ordinator excluded 1999 references because the topic was not related to the topic of this review.

\section{Selection}

A total of 130 references appeared to be relevant and were further screened by the review authors (WJ, PW). After screening the titles and abstracts, we excluded 92 references. We excluded a further 21 references after screening the full text of the article, including fifteen randomised studies on disc arthroplasty initially included by one reviewer, but then excluded after consensus since disc arthroplasty was not included in this review. Neglecting the disc arthroplasty studies, the inter-rater kappa was 0.75 . See Characteristics of excluded studies for further details. Screening the reference lists of the new studies yielded 36 new references, one of which could be included. Citation tracing yielded 213 new references, and also resulted in one new inclusion. One study (Lofgren 2010) was encountered and included alongside the search through a journal issue alert, this study referenced several included studies, but apparently this article was not (yet) indexed in Web of Science citation tracking.

Finally, 20 articles were included describing 19 new studies. One article presented further results for Vavruch 2002. Wigfield 2003 was in the Studies awaiting classification section and has now been excluded. Together with the 20 articles describing 14 studies from the previous review, a total of 40 articles describing 33 studies were included in this review. 
Ten articles described three studies: four articles for Zoega 2000, two articles for Hacker 2000 and four articles for Vavruch 2002. Only one article was identified as the primary data source, although additional data were extracted from the other studies as indicated.

\section{Comparisons}

The comparisons made in the trials evaluated a range of anterior fusion techniques. Because of clinical heterogeneity, we grouped these comparisons into:

1. Discectomy alone versus human bone graft

2. Discectomy alone versus cages or cement

3. Discectomy alone versus iliac crest autograft with plates

4. Iliac crest autograft versus human allograft or bone substitute

5. Iliac crest autograft versus cages

6. Iliac crest autograft versus iliac crest autograft with plates

7. Different types of autograft

8. Allograft versus cages

9. Comparisons between different types of instrumentation Although there are still some variations between treatments within these comparisons, we felt that these categories were based on basic differences between treatment options. This decision was made after selection of the studies.

\section{Sponsorship}

The studies that explicitly reported to have received no funds were Fernandez-Fairen 2008; Hauerberg 2008. The studies that explicitly declared no conflict of interest were Celik 2007; Nunley 2009; Thome 2006.

Lofgren 2000 received support from the County Council of Jonkøping. Zoega 2000 received grants from the Gothenburg Medical Society, Greta and Einers Foundation, and Gothenburg University. Dai 2008 was supported by Shanghai Natural Science Foundation. Peolsson 2003 and Peolsson 2007 (Secondary studies for Vavruch 2002) received support from Linkøping University and FORSS research council.

There was no mention of sponsorship in most of the trials (Abd-Alrahman 1999; Barlocher 2002; Dowd 1999; Lind 2007; Madawi 1996; Martins 1976; McConnel 2003; McGuire 1994; Nabhan 2007; Oktenoglu 2007; Pan 2005; Porras-Estrada 2004; Rosenorn 1983; Ruetten 2009; Ryu 2006; Savolainen 1998; Schroder 2007; van den Bent 1996; Vavruch 2002; Xie 2007).

Baskin 2003 mentioned Corporate and industry funds, which were directed to a research fund, foundation, educational institution or other nonprofit organization.

The study of Feiz-Erfan 2007 was sponsored by DePuy, Johnson\& Johnson. One of the authors of Hacker 2000 was employed by Sulzer Spine tech. One of the authors of Stulik 2007 is a consultant to Aesculap. The study of Lofgren 2010 was in part supported by a research grant from Zimmer.

\section{Risk of bias in included studies}

The risk of bias in the studies was variable, but often high, especially concerning randomisation, allocation concealment and blinding. This might have been the result of either poor methodology or poor reporting. Blinding is rarely used in orthopedic surgical trials, as is confirmed by the studies found in this review. No study used surgeon blinding. Two studies used patient blinding and four studies used outcome assessor blinding. The randomisation technique was mentioned in 13 of the 33 trials and valid allocation concealment in 11 of the 33 studies. Eight studies used both valid randomisation and allocation concealment techniques. The risk of bias summary of the trials is shown in Figure 1. Clinical relevance assessment of the studies is given in Table 2. Results were not sufficiently reported for one- or two-level procedures to produce a reliable subgroup analysis. 
Figure I. Summary of risks of bias

\begin{tabular}{|c|c|c|c|c|c|c|c|c|c|c|c|c|}
\hline & 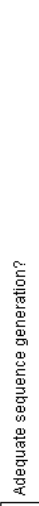 & 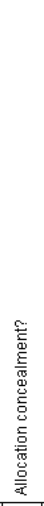 & 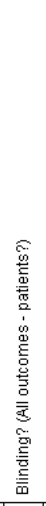 & 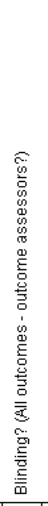 & 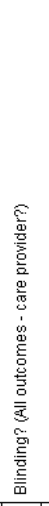 & 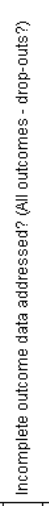 & 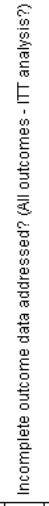 & 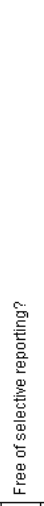 & 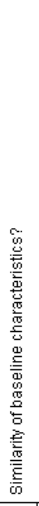 & 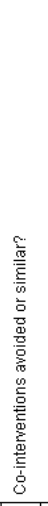 & 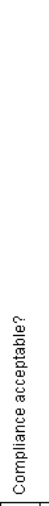 & 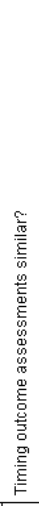 \\
\hline Abd-Alrahman 1999 & $?$ & $?$ & - & $\odot$ & ○ & † & 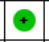 & $?$ & $?$ & + & + & + \\
\hline Barlocher 2002 & $?$ & $?$ & $?$ & $?$ & $?$ & $\odot$ & $\odot$ & ○ & $\odot$ & $\odot$ & $\odot$ & $\odot$ \\
\hline Baskin 2003 & $?$ & $?$ & - & $\odot$ & $\odot$ & $\odot$ & $\odot$ & $?$ & $\odot$ & + & + & + \\
\hline Celik 2007 & $?$ & ○ & $\theta$ & $?$ & - & $?$ & $\odot$ & $\odot$ & $\odot$ & $\odot$ & $\odot$ & $\odot$ \\
\hline Dai 2008 & $?$ & $?$ & $?$ & $\odot$ & $\theta$ & $\odot$ & $\odot$ & $\odot$ & $\odot$ & + & + & † \\
\hline Dowd 1999 & + & 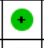 & - & - & $\theta$ & O & $?$ & $?$ & $\odot$ & + & $\odot$ & + \\
\hline Feiz-Erfan 2007 & $?$ & $?$ & $\odot$ & $?$ & - & ? & $\odot$ & ○ & $?$ & $\odot$ & $\odot$ & $\odot$ \\
\hline Fernandez-Fairen 2008 & + & $?$ & - & $\odot$ & - & $?$ & $\odot$ & $\odot$ & $\odot$ & $\odot$ & $\odot$ & $\odot$ \\
\hline Hacker 2000 & $?$ & $?$ & $\theta$ & - & $\theta$ & 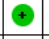 & $\odot$ & $?$ & $\odot$ & $\odot$ & $\odot$ & + \\
\hline Hauerberg 2008 & $\odot$ & ( & $\theta$ & ○ & ○ & $\odot$ & $\odot$ & $\odot$ & $\odot$ & $\Theta$ & $\odot$ & $\odot$ \\
\hline Lind 2007 & $?$ & ๑ & O & $\odot$ & $\theta$ & $\odot$ & + & ○ & ○ & $\odot$ & $\odot$ & $\odot$ \\
\hline Lofgren 2000 & + & - & $\theta$ & $\odot$ & - & ○ & $\odot$ & - & $?$ & + & ๑ & + \\
\hline Lofgren 2010 & $?$ & ๑ & $\theta$ & - & $?$ & + & + & ( & + & + & + & + \\
\hline Madawi 1996 & $?$ & $?$ & ? & $\theta$ & $\theta$ & $?$ & $\odot$ & $\odot$ & ๑ & $\odot$ & ๑ & $?$ \\
\hline Martins 1976 & $?$ & $?$ & ○ & - & ○ & $?$ & $\odot$ & $?$ & $?$ & † & ๑ & † \\
\hline McConnel 2003 & + & ๑ & $\theta$ & - & $\theta$ & $?$ & $\odot$ & ๑ & $\odot$ & $\odot$ & $\odot$ & $\odot$ \\
\hline McGuire 1994 & $?$ & $?$ & 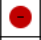 & - & - & $?$ & $?$ & $?$ & $?$ & $\odot$ & $?$ & $\odot$ \\
\hline Nabhan 2007 & $?$ & ๑ & $\theta$ & ? & - & $\odot$ & $?$ & $\odot$ & $?$ & + & + & + \\
\hline Nunley 2009 & + & $?$ & • & $\odot$ & $\theta$ & 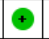 & $\odot$ & - & $?$ & (†) & + & $?$ \\
\hline Oktenoglu 2007 & $\odot$ & ๑ & ○ & • & ○ & $\odot$ & $\odot$ & (†) & $?$ & $?$ & (†) & $?$ \\
\hline Pan 2005 & $?$ & ? & ○ & $?$ & $\theta$ & $\theta$ & - & $\odot$ & $?$ & ○ & $\odot$ & † \\
\hline Porras-Estrada 2004 & $?$ & $?$ & $?$ & $?$ & అ & $\odot$ & (†) & $\odot$ & $\odot$ & $\odot$ & 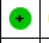 & $?$ \\
\hline Rosenorn 1983 & $?$ & $?$ & 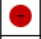 & ○ & - & $\odot$ & $\odot$ & $?$ & $?$ & $\odot$ & $\odot$ & $\odot$ \\
\hline Ruetten 2009 & $?$ & $?$ & $\theta$ & $\odot$ & - & $\odot$ & $?$ & $\odot$ & $\odot$ & ○ & $\odot$ & $\odot$ \\
\hline Ryu 2006 & $?$ & $?$ & $\theta$ & $\odot$ & - & $\odot$ & $\odot$ & $\odot$ & $\odot$ & $\odot$ & $\odot$ & + \\
\hline Savolainen 1998 & $?$ & $?$ & ○ & ○ & ○ & † & + & ? & + & + & + & + \\
\hline Schroder 2007 & † & $?$ & $?$ & - & - & $\odot$ & $\odot$ & $\odot$ & ๑ & ๑ & ๑ & $\odot$ \\
\hline Stulik 2007 & $?$ & $?$ & $?$ & - & ○ & ○ & $\odot$ & ( & $\odot$ & $\odot$ & ๑) & $\odot$ \\
\hline Thome 2006 & $\odot$ & $?$ & $?$ & $?$ & ○ & $\odot$ & $\odot$ & $\odot$ & $\odot$ & $\odot$ & $\odot$ & $\odot$ \\
\hline van den Bent 1996 & $\odot$ & $\odot$ & ○ & ○ & ○ & ๑ & $\odot$ & ○ & $\odot$ & ๑ & $\odot$ & $\odot$ \\
\hline Vavruch 2002 & $\odot$ & ๑ & 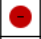 & ○) & - & $?$ & $\odot$ & $\odot$ & $\odot$ & $\odot$ & $\odot$ & $\odot$ \\
\hline Xie 2007 & † & $?$ & ○ & ○ & ○ & ○ & $\odot$ & 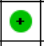 & ○ & (†) & + & + \\
\hline Zoega 2000 & + & ( & $\theta$ & $\odot$ & $\theta$ & + & $\odot$ & (๑) & $\odot$ & + & $\odot$ & + \\
\hline
\end{tabular}




\section{Effects of interventions}

\section{Analysis}

When aggregate, pooled estimates were statistically heterogeneous, we did not produce a forest plot, except for homogeneous subgroups. When only one study with a high risk of bias was found, the data were entered into the data and analyses section, but no forest plot was made and the result was not discussed in a quantitative analysis. When only one study with a low risk of bias was found, the data were entered into the data and analyses section and the effect was depicted in a singular forest plot of the primary outcome parameter, and the result was analysed in a quantitative analysis.

Group sizes are given in number of patients, unless otherwise specified. In the comparisons and tables, the results are listed for each outcome variable for each comparison. Custom-made scoring systems are not reproduced as these cannot be pooled. Data from all studies were entered into the data and analyses section.

\section{Discectomy alone versus human bone graft}

Seven small studies with 487 patients were found that compared discectomy alone $(\mathrm{N}=220)$ with bone graft $(\mathrm{N}=267)$. Apart from Martins 1976 (graft not mentioned) and Rosenorn 1983 (freeze dried bone graft), all studies used iliac crest autograft.

Abd-Alrahman 1999 compared discectomy alone with fusion (Smith and Robinson technique) using autologous iliac crest graft $(\mathrm{N}=90)$. Dowd 1999 compared discectomy alone with fusion using autologous iliac crest graft (Cloward technique) $(\mathrm{N}=84)$. Martins 1976 compared discectomy alone with fusion (Cloward technique) $(\mathrm{N}=51)$. Rosenorn 1983 compared discectomy alone with fusion with freeze dried bone grafts (Cloward technique) (N =63). van den Bent 1996 compared discectomy alone with fusion with polymethyl methacrylate (PMMA) $(\mathrm{N}=81)$. Savolainen 1998 compared discectomy alone with fusion with iliac crest autograft (Smith and Robinson) (N = 61). Xie 2007 compared discectomy alone with iliac crest autograft $(\mathrm{N}=30)$. Barlocher 2002 compared microdiscectomy only with iliac crest autograft $(\mathrm{N}=$ 63).

Abd-Alrahman 1999 and Savolainen 1998 concluded that there was no difference between the two techniques. Dowd 1999 concluded that the addition of a fusion procedure was not absolutely necessary. Martins 1976 found no difference between the groups, but preferred discectomy for soft disc herniations and fusion for patients with advanced spondylosis. Xie 2007 found no difference in clinical results, but concluded that discectomy alone resulted in segmental kyphosis compared with fusion with autograft or fusion with autograft and anterior plate. Rosenorn 1983 concluded that for soft disc herniation, discectomy was an easier procedure and resulted in a shorter hospital stay and sick leave. Barlocher 2002 did not draw any definite conclusions on this specific comparison. Only Dowd 1999 was assessed as having a low risk of bias.

There are nine outcome measures reported in the six studies evaluating this comparison. Xie 2007 reported arm pain, neck pain and McGill Pain Scale scores in figures only, which did not allow data extraction. Barlocher 2002 only reported percentage of improvement for arm and neck pain. Operation time, hospital stay and blood loss were additional parameters, the results for which can be found in the Data and analyses section.

In summary, between those who received discectomy and those who received iliac crest autograft, there is low quality evidence that there was no significant difference in short-term pain relief ( 1 RCT, 84 participants, RR 0.82 ; $95 \%$ CI 0.20 to 3.46 ) and very low quality evidence that there was no significant difference in Odom's criteria (2 RCTs, 149 participants, RR 0.95; 95\% CI 0.82 to 1.10 ); short-term return-to-work (2 RCTs, 144 participants, RR 1.26; $95 \%$ CI 1.02 to 1.54 ); or intermediate-term return-towork (2 RCTs, 70 participants, RR 1.44; 95\% CI 0.77 to 2.69 ). There is moderate quality evidence that bone graft was more effective than discectomy alone in achieving fusion (5 RCTs, 303 participants, RR $0.22 ; 95 \%$ CI 0.17 to 0.48 ) and very low quality evidence that there was no significant difference in alignment (2 RCTs, 75 participants, RR 0.34; 95\% CI 0.07 to 1.56). There is moderate quality evidence that there was no significant difference in complication rates (7 RCTs, 487 participants, OR 1.56; 95\% CI 0.71 to 3.43). Future research is very likely to change the results and our confidence in them.

\section{Pain}

- There is low quality evidence (suspected publication bias, imprecise estimate), from one study (Dowd 1999; $\mathrm{N}=84$ ) that the difference in short-term ( 5 weeks) pain relief between the groups who received discectomy and those who received iliac crest autograft is not statistically significant (RR 0.82; 95\% CI 0.20 to 3.46 ).

\section{Other clinical outcome}

- There is very low quality evidence (high risk of bias, imprecise estimate, suspected publication bias) from two studies (Abd-Alrahman 1999; Barlocher 2002; $N=149$ ) that there is no statistically significant difference in Odom's criteria between the groups that received discectomy and those who received iliac crest autograft (RR $0.95 ; 95 \%$ CI 0.82 to $1.10 ; \mathrm{P}=0.47$ ).

- There is very low quality evidence (high risk of bias, imprecise estimate, suspected publication bias) from two studies (Dowd 1999; Rosenorn 1983; $\mathrm{N}=144$ ) that discectomy is more 
effective than autograft in improving return-to-work at five weeks (RR 1.26; 95\% CI 1.02 to $1.54 ; \mathrm{P}=0.03$ ).

- There is very low quality evidence (high risk of bias, imprecise estimate, suspected publication bias) from two studies (Dowd 1999; Rosenorn 1983; $\mathrm{N}=70$ ) that there is no statistically significant difference in return-to-work at 10 weeks between discectomy and autograft (RR 1.44; 95\% CI 0.77 to 2.69; $\mathrm{P}=0.25)$.

\section{Radiological}

- There is moderate quality evidence (high risk of bias) from five studies (Abd-Alrahman 1999; Barlocher 2002; Dowd 1999; Savolainen 1998; Xie 2007; N = 303) that bone graft is more effective than discectomy alone in achieving fusion. (RR 0.22; $95 \%$ CI 0.10 to 0.49 ; $\mathrm{P}=0.0002$; see Figure 2).

Figure 2. Forest plot of comparison: I Discectomy alone vs bone graft, outcome: I.8 No Fusion.

\begin{tabular}{|c|c|c|c|c|c|c|c|c|}
\hline \multirow[b]{2}{*}{ Study or Subgroup } & \multicolumn{2}{|c|}{ Fusion } & \multicolumn{2}{|c|}{ discectormy } & \multirow[b]{2}{*}{ Weight } & \multirow{2}{*}{$\begin{array}{c}\text { Risk Ratio } \\
\text { M-H, Random, 95\% Cl }\end{array}$} & \multirow{2}{*}{\multicolumn{2}{|c|}{$\begin{array}{c}\text { Risk Ratio } \\
\text { M-H, Random, } 95 \% \mathrm{Cl}\end{array}$}} \\
\hline & Events & Total & Events & Total & & & & \\
\hline Abd-Alrahman 1999 (1) & 3 & 50 & 14 & 40 & $45.1 \%$ & $0.17[0.05,0.56]$ & & \\
\hline Barlocher 2002 & 2 & 30 & 2 & 33 & $17.3 \%$ & $1.10[0.17,7.33]$ & & \\
\hline Dowd 1999 (2) & 1 & 31 & 9 & 31 & $15.5 \%$ & $0.11[0.01,0.83]$ & & \\
\hline Savolainen 1998 (3) & 0 & 30 & 3 & 31 & $7.3 \%$ & $0.15[0.01,2.74]$ & $\longleftarrow$ & \\
\hline Xie 2007 (4) & 1 & 15 & 4 & 12 & $14.8 \%$ & $0.20[0.03,1.56]$ & & \\
\hline Total $(95 \% \mathrm{Cl})$ & & 156 & & 147 & $100.0 \%$ & $0.22[0.10,0.49]$ & & \\
\hline Total events & 7 & & 32 & & & & & \\
\hline $\begin{array}{l}\text { Heterogeneity: } \operatorname{Tau}^{2}=0 . \\
\text { Test for overall effect: } Z=\end{array}$ & $\begin{array}{l}\text {; } \mathrm{Chi}^{2}=3 \\
3.72(\mathrm{P}=\end{array}$ & $\begin{array}{l}49, \mathrm{df}= \\
0.0002)\end{array}$ & $=4(P=$ & (.48); $\left.\right|^{2}=$ & $=0 \%$ & & $\begin{array}{l}1 \\
0.01 \\
\text { Favours Fusion }\end{array}$ & $\begin{array}{|cc|}10 & 100 \\
\text { Favours Discectomy }\end{array}$ \\
\hline $\begin{array}{l}\text { (1) } 2 \text { years } \\
\text { (2) } 3 \text { years } \\
\text { (3) } 6 \text { months } \\
\text { (4) } 2 \text { years }\end{array}$ & & & & & & & & \\
\hline
\end{tabular}

- There is very low quality evidence (high risk of bias, imprecision, suspected publication bias) from two studies (Martins 1976; Xie 2007; $\mathrm{N}=75$ ) that there is no statistically significant difference between discectomy alone and human bone graft in achieving a fair or poor alignment (RR 0.34; 95\% CI 0.07 to 1.56 ).

\section{Complications}

- There is moderate quality evidence (high risk of bias) from seven studies (Abd-Alrahman 1999; Barlocher 2002; Dowd
1999; Martins 1976; Rosenorn 1983; Savolainen 1998; Xie $2007 ; \mathrm{N}=487$ ) that the difference in complication rate between discectomy alone and iliac crest autograft is not statistically significant (OR 1.56; 95\% CI 0.71 to 3.43; $\mathrm{P}=0.27$; see Figure $3)$. In the discectomy group, eight complications were reported (6 re-operations, 1 nerve lesion, 1 staphylococcus aureus infection); in the human bone graft group, thirteen complications ( 4 re-operations, 2 infection, 2 hematoma, 1 graft loosening, 1 iliac crest pain, 1 iliac crest fracture) were reported. 
Figure 3. Forest plot of comparison: I2.I complications.

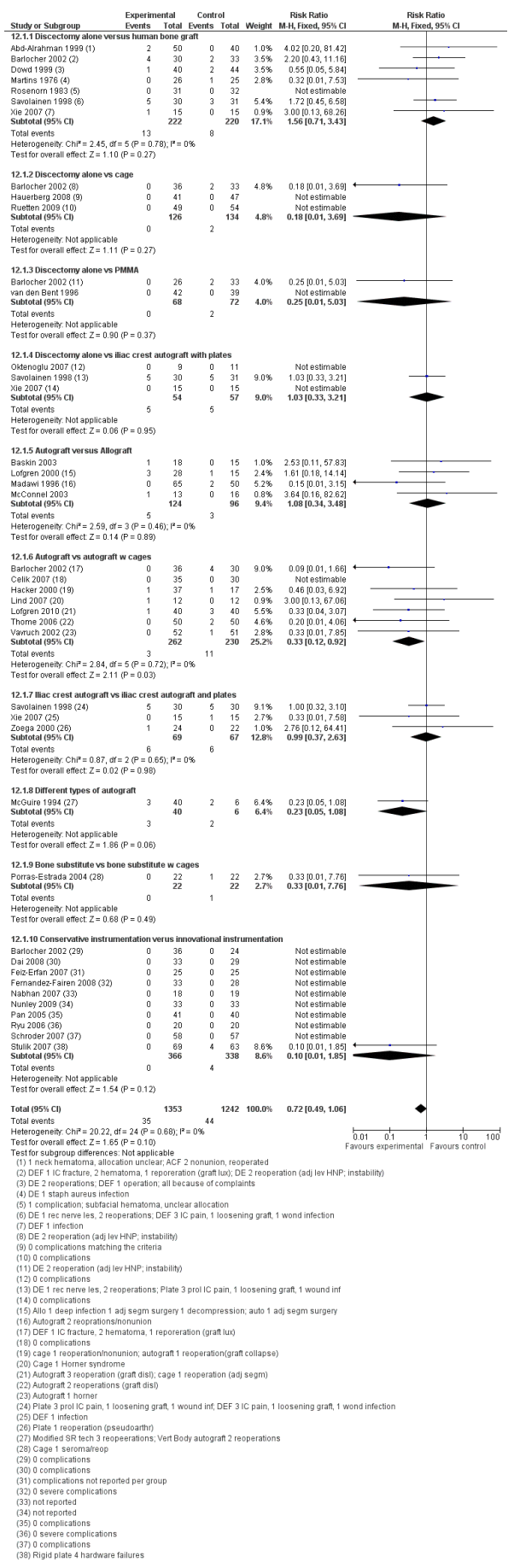




\section{Discectomy alone vs cages or cement}

Four small studies compared discectomy alone with a cage or with intervertebral cement. Two studies used a cage, one used cement, and one used both. The studies were clinically too heterogeneous to be analysed together.

Three studies (Barlocher 2002; Hauerberg 2008; Ruetten 2009) with 277 patients compared discectomy alone $(\mathrm{N}=140)$ with a cage $(\mathrm{N}=137)$. Hauerberg 2008 compared discectomy alone with cages $(\mathrm{N}=88)$. Ruetten 2009 compared full-endoscopic anterior decompression with conventional anterior decompression with a PEEK cage $(\mathrm{N}=120)$. Barlocher 2002 compared discectomy alone with $\mathrm{BAK} / \mathrm{C} \AA$ cage filled with Tutoplast $(\mathrm{N}=69)$.

Hauerberg 2008 and Ruetten 2009 found no difference between discectomy alone and the use of titanium or PEEK cages. Barlocher 2002 concluded that the cage yields a significantly better shortand intermediate-term outcome in terms of radicular pain, Odom's criteria; return-to-work, and earlier fusion.

Only Hauerberg 2008 was assessed as having a low risk of bias. Hauerberg 2008 reported arm and neck pain, recovery, operation time, blood loss, and fusion at 24 months. Ruetten 2009 reported VAS arm pain, VAS neck pain, NASS (North America Spine Society Instrument), operation time, blood loss, Hilibrand criteria and MRI/CT outcome. Only final, 24-month follow-up could be used, because it was unclear when patients were lost to followup. Furthermore, VAS and NASS score variance could not be estimated due to lack of additional studies providing this information. Also, fusion was poorly reported and could not be used. Barlocher 2002 reported VAS pain (only percentage change), Odom's criteria, hospital stay, operation time, blood loss and fusion. Operation time was reported in three studies, but showed considerable heterogeneity, probably due to differences in reporting (mean versus median) and could not be further analysed. Ruetten 2009 reported VAS arm pain, VAS neck pain, and NASS pain and neurology (at 24 months) but SD was not reported and could not be inferred from other studies in this comparison.

In summary, between those who received discectomy alone and those who received a cage, there was no evidence for pain relief, and very low quality evidence that there was no significant difference in recovery (1 RCT, 64 participants, RR 1.12; 95\% CI 0.91 to 1.38), or preventing non-fusion (3 RCTs, 250 participants, RR $0.65 ; 95 \%$ CI 0.09 to 4.42 ). There was moderate quality evidence that there were no significant differences in complication rates (3 RCTs, 260 participants).

\section{Pain}

- There were no RCTs comparing discectomy alone with a cage that adequately reported the effect on pain.

\section{Other clinical outcome}

- There is very low quality evidence (imprecise estimate, nongeneralisable, suspicion of publication bias) from one study (Hauerberg 2008; $\mathrm{N}=64$ ) that there is no statistically significant difference in recovery between discectomy alone and cages (RR 1.12 ; $95 \%$ CI 0.91 to $1.38 ; \mathrm{P}=0.28)$.

\section{Radiological}

- There is low quality evidence (high risk of bias, imprecision) from three studies (Barlocher 2002; Hauerberg 2008; Ruetten 2009; $\mathrm{N}=250$ ) that there is no statistically significant difference between discectomy and a cage in preventing non-fusion (RR 0.65 ; $95 \%$ CI 0.09 to 4.42 ; $\mathrm{P}=0.66)$.

\section{Complications}

- There is moderate quality evidence (high risk of bias) from three studies (Barlocher 2002; Hauerberg 2008; Ruetten 2009; $\mathrm{N}=260$ ) that the difference in complication rate between discectomy alone and a cage is not statistically significant. There were only two re-operations in one study in the discectomy group.

Two small studies (Barlocher 2002; van den Bent 1996) with 140 patients compared discectomy alone $(\mathrm{N}=72)$ with polymethyl methacrylate (PMMA) $(\mathrm{N}=68)$. van den Bent 1996 compared discectomy alone with PMMA $(\mathrm{N}=81)$. Barlocher 2002 compared discectomy alone with PMMA $(\mathrm{N}=59)$.

van den Bent 1996 found no difference and concluded that the addition of PMMA was not recommended for herniated intervertebral discs. Barlocher 2002 found a lack of fusion in the PMMA group, but concluded that PMMA was a good alternative to a fusion cage.

One study with a low risk of bias (van den Bent 1996, met 7 of 12 items; with adequate randomisation and allocation concealment) and one study with high risk of bias (Barlocher 2002, met 6 of 12 items, no adequate randomisation or allocation concealment) were included in this comparison. From the studies, the following quantitative analysis could be performed.

In summary, between those who received discectomy alone and those who received a bone substitute (PMMA cement) there was low quality evidence that there is no statistically significant difference for "Pain not relieved at 6 weeks" (2 RCT, 140 participants, RR 0.75 ; $95 \%$ CI 0.21 to 2.66 ) and no evidence for other clinical outcomes or complications. There was moderate quality evidence 
that there is no significant difference for "Pain not relieved at 1 to 2 years" (2 RCT, 140 participants, RR 1.05; 95\% CI 0.69 to 1.61). There were no RCTs comparing discectomy alone and use of PMMA that reported clinical outcomes.

\section{Pain}

- There is low quality (high risk of bias, imprecision) evidence from two studies (Barlocher 2002; van den Bent 1996; $\mathrm{N}=140$ ) that there is no statistically significant difference between discectomy alone and a bone substitute (PMMA) for "Pain not relieved at 6 weeks" (RR 0.75; 95\% CI 0.21 to 2.66; $\mathrm{P}=0.66$ ).

- There is moderate quality evidence (high risk of bias) from two studies (Barlocher 2002; van den Bent 1996; $\mathrm{N}=140$ ) that there is no statistically significant difference between discectomy alone and a bone substitute (PMMA) for "Pain not relieved at 1 to 2 years" (RR $1.05 ; 95 \%$ CI 0.69 to $1.61 ; \mathrm{P}=0.81$; see Figure 4).

Figure 4. Forest plot of comparison: 2 Discectomy alone vs cage, outcome: 2.6 Pain not relieved at 2 years.

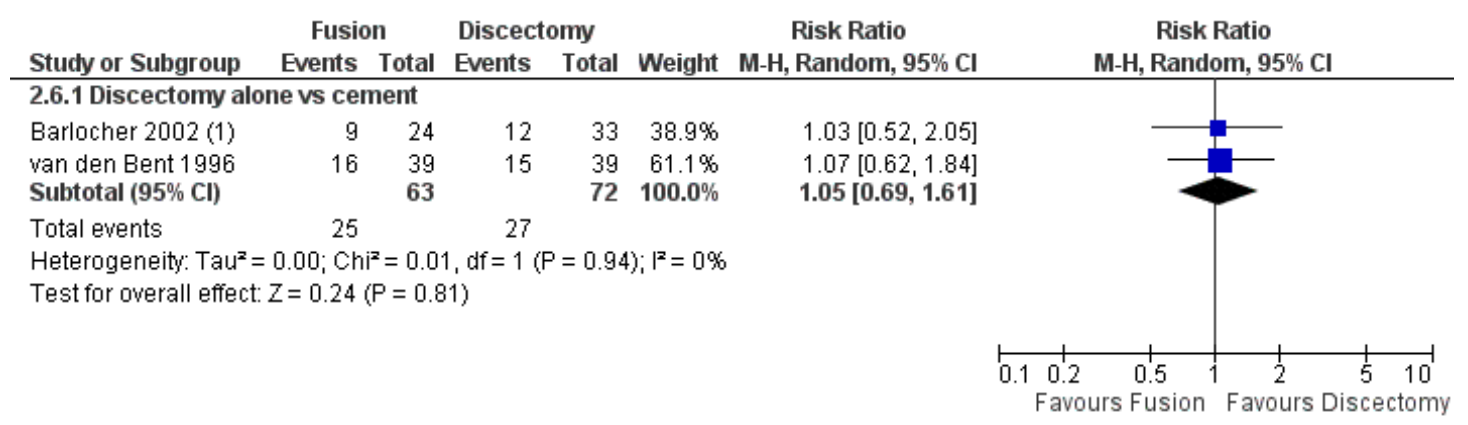

(1) 12 months

\section{Other clinical outcome}

- There were no RCTs comparing discectomy alone and use of PMMA that reported clinical outcomes.

\section{Radiological}

- Fusion was reported in two studies (Barlocher 2002; van den Bent 1996; $\mathrm{N}=140$ ). The pooled result showed significant heterogeneity, so this comparison could not be further analysed.

\section{Complications}

- Serious complications were not reported in one study (van den Bent 1996) and there were two serious complications (reoperations) in the discectomy group in one study (Barlocher 2002).

\section{Discectomy alone vs human bone graft with plates}

Three small studies (Oktenoglu 2007; Savolainen 1998; Xie 2007; $\mathrm{N}=111)$ compared discectomy alone $(\mathrm{N}=57)$ with human bone graft and anterior plates $(\mathrm{N}=54)$.

Xie 2007 compared discectomy alone with discectomy and fusion with iliac crest autograft and an Codman anterior cervical plate $(\mathrm{N}=30)$. Savolainen 1998 compared discectomy alone with discectomy and fusion with iliac crest autograft and anterior Caspar plate $(\mathrm{N}=61)$. Oktenoglu 2007 compared anterior cervical discectomy with complementary fusion with Tutoplast (Tutogen) allograft with semirigid anterior screw plate (Tnipsan) $(\mathrm{N}=20)$. Xie 2007 concluded that there were no significant differences between the groups, apart from segmental kyphosis in the discectomy alone group. Savolainen 1998 found no significant differences in clinical outcome and a slightly better fusion rate for the plate group. Oktenoglu 2007 concluded there were no significant differences between the groups except for a smaller decrease of disc height for the plate group.

One study (Oktenoglu 2007, met 7 of 12 items) met more than $50 \%$ of the risk of bias assessment criteria, with proper randomisation and allocation concealment and can be regarded as having a low risk of bias. The other two studies (Savolainen 1998; Xie 2007) met $50 \%$ or more of the criteria, but only Xie 2007 used a 
proper randomisation technique.

There were 12 outcome parameters reported in the three studies evaluating this comparison. Xie 2007 reported arm pain, neck pain, American Spinal Injury Association score, SF-36, McGill Pain Scale score and segmental alignment in figures only, which did not allow data extraction, leaving alignment and fusion. Adjacent segment parameters (Oktenoglu 2007) were not included in this analysis. Kyphosis reported in Savolainen 1998 could not be included because it failed a definition of kyphosis.

In summary, between those who received discectomy alone and those who received anterior plating, there was very low quality evidence that there was no significant difference for VAS arm pain (1 trial, 2 participants, MD -0.16; $95 \%$ CI -0.85 to 0.53 ) or Odom's criteria (1 RCT, 61 participants, RR 0.96; 95\% CI 0.71 to 1.28 ). There was very low quality evidence that bone graft with anterior plating results in better neck pain relief than discectomy alone (1 trial, 20 participants, MD 0.81 favouring plating 95\% CI 0.20 to 1.42 ). There was very low quality evidence that there was no statistically significant difference in achieving fusion (2 RCT, 91 participants, RR 1.10; $95 \%$ CI 0.96 to 1.27 ).

\section{Pain}

- There is very low quality evidence (suspected publication bias, non-generalisable, imprecision) from one study (Oktenoglu 2007; $N=20$ ) that there is no statistically significant difference between discectomy alone and anterior plating for VAS arm pain (MD -0.16; 95\% CI -0.85 to 0.53 ; $\mathrm{P}=0.65$ ).

- There is very low quality evidence (suspected publication bias, non-generalisable, imprecision) from one study (Oktenoglu 2007; $N=20$ ) that bone graft with anterior plating results in better neck pain relief than discectomy alone (MD 0.81 favouring plating $95 \%$ CI 0.20 to $1.42 ; \mathrm{P}=0.009$ ).

\section{Other clinical outcome}

- There is very low quality evidence (high risk of bias, nongeneralisable, imprecision, suspected publication bias) from one study (Savolainen 1998; N = 61) that there is no statistically significant difference between discectomy alone and graft with an anterior plate in Odom's criteria (RR $0.96 ; 95 \%$ CI 0.71 to $1.28 ; \mathrm{P}=0.77)$.

\section{Radiological}

- There is very low quality evidence (high risk of bias, imprecision, suspected publication bias) from two studies (Savolainen 1998; Xie 2007; N = 91) that there is no statistically significant difference between discectomy alone and graft with anterior plate in achieving fusion (RR $1.10 ; 95 \%$ CI 0.96 to 1.27; $\mathrm{P}=0.15$ ).

\section{Complications}

- Complications were reported in all three studies. Two studies reported no serious complications, one study reported five complications in each group. The conclusion is that the difference in complication rate between the two groups is not clinically significant.

\section{4. lliac crest autograft vs human allograft or bone substitute}

Four small studies with 220 patients compared fusion with autograft $(\mathrm{N}=96)$ versus any kind of allograft $(\mathrm{N}=124)$. Lofgren 2000 compared autograft, human allograft, and bovine allograft $(\mathrm{N}=$ 41). Madawi 1996 compared autograft with biocompatible osteo conductive polymer (BOP) graft $(\mathrm{N}=115)$. Baskin $2003 \mathrm{com}$ pared autograft with recombinant human bone morphogenetic protein-2 (rhBMP-2)-laden collagen carrier $(\mathrm{N}=33)$ as a filler for fibular allograft. McConnel 2003 compared autograft with ProOsteon ${ }^{\circledR} 200$ hydroxyapatite $(\mathrm{N}=29)$.

Lofgren 2000 found no difference between any grafts, except autograft resulted in better pain reduction than bovine allograft. Madawi 1996 concluded that there was no difference between biocompatible osteo conductive polymer (BOP) and autograft. Baskin 2003 concluded that recombinant human bone morphogenetic protein-2 (rh-BMP-2) was a safe replacement for iliac crest autograft. The Neck Disability Index and arm pain were favourable for the rh-BMP group at 24 months. McConnel 2003 concluded that the integrity of the ProOsteon ${ }^{\circledR}$ blocks was not sufficient. Differences were not found at the final follow-up, because the trial was terminated due to radiographic fragmentation and collapse of the ProOsteon ${ }^{\circledR}$ graft. The risk of bias of these studies was high. The treatments examined in this comparison were too clinically heterogeneous to combine any of the results in a meta-analysis. This comparison is therefore not used further in a meta-analysis. Primary outcomes of the two studies with low risk of bias were pain (total, arm and neck) for Lofgren 2000, and SF-36 and fusion for McConnel 2003, but the latter did not report any usable information. Lofgren 2000 only reported change scores for arm pain and neck pain, so these also could not be analysed.

\section{5. lliac crest autograft vs cage}

Seven small studies (Barlocher 2002; Celik 2007; Hacker 2000; Lind 2007; Lofgren 2010; Thome 2006; Vavruch 2002) with 889 patients compared iliac crest autograft $(\mathrm{N}=355)$ versus a cage $(\mathrm{N}=$ 534). Generally, the cages were either not filled or were filled with local autograft or bone substitute, all autograft groups received iliac crest autograft. Barlocher 2002 also compared iliac crest autograft with PMMA spacer $(\mathrm{N}=56)$.

Hacker et al (Hacker 2000) compared autograft with BAK-C® cage filled with local bone reamings $(\mathrm{N}=54)$. This study is a subgroup of a larger study; data of this larger study could not be included because of the limited percentage of patients with 
follow-up data. Vavruch et al (Vavruch 2002) compared autograft with CIFC cage ${ }^{\circledR}$ filled with iliac crest autograft $(\mathrm{N}=89)$. Celik 2007 compared autograft with PEEK cage filled with local bone graft $(\mathrm{N}=65)$. Lofgren 2010 compared iliac crest autograft with a Trabecular Metal (TM) cage; the cage was not filled with bone graft $(\mathrm{N}=80)$. Thome 2006 compared iliac crest autograft with RABEA titanium cages, not filled with bone graft $(\mathrm{N}=100)$. Lind 2007 compared Smith and Robinson iliac crest autograft with BAK-C® cylindrical threaded titanium cage filled with local bone graft $(\mathrm{N}=83)$. Barlocher 2002 compared microdiscectomy alone with a BAK-C@ threaded titanium cage filled with Tutoplast bone substitute $(\mathrm{N}=69)$.

Celik 2007 concluded that foraminal height was better preserved in the cage group, but there was no difference between the groups on clinical aspects. Vavruch 2002 concluded that lordotic alignment and disc height increased but with more pseudoarthrosis for the cage group and with less donor site pain, but there were no further clinical differences. Lind 2007 concluded that neck and arm pain and Odom's criteria after two years were better for the cage group, but there were no radiological differences. Thome 2006 concluded that overall pain relief was better in the cage group, but there were also no radiological differences between the groups. Hacker 2000 found no clinical differences, except more complications in the autograft group, and concluded that the cage was 'safe and effective'. Lofgren 2010 concluded that there were no clinical differences, apart from a shorter operation time with Trabecular Metal(TM) implants.

Only Vavruch 2002 had a valid randomisation technique and allocation concealment. Thus, one study with low risk of bias (Vavruch 2002) and six studies with high risk of bias (Barlocher 2002; Celik 2007; Hacker 2000; Lind 2007; Lofgren 2010; Thome 2006) compared iliac crest autograft with a cage.

There were 15 outcome parameters reported in the studies. Celik 2007 only reported postoperative values for VAS arm, VAS neck pain and JOA averaged for all postoperative assessments, therefore these data could not be included in the analyses. Lind 2007 only reported VAS arm and VAS neck in graphs, which prohibited us from extracting reliable data. Hacker 2000 only reported clinical outcomes in a subgroup analysis in a separate publication and only reported SF-36 in graphs, which did not permit data extraction. The results of the subgroup analysis are included in this analysis. Barlocher 2002 only reported percentage of improvement for arm and neck pain.

In summary, between those who received iliac crest autograft and those who received a cage, there is very low quality evidence that the difference in VAS arm pain is not statistically significant (2 RCT, 180 participants, MD -0.29 ; $95 \%$ CI -0.90 to 0.33 ). There is moderate quality evidence that the difference in Odom's criteria is not statistically significant (6 RCT, 412 participants, RR 1.11; $95 \%$ CI 0.99 to 1.24 ). There is low quality evidence that iliac crest autograft is more effective in achieving fusion than a cage (5 RCT, 424 participants, OR 1.87; 95\% CI 1.10 to 3.17). There is low quality evidence that cages are more effective in preventing complications than iliac crest autograft (7 RCT, 889 participants, OR 0.32 ; $95 \%$ CI 0.11 to 0.92 ).

\section{Pain}

- There is very low quality evidence (high risk of bias, imprecision, suspected publication bias) from two studies (Lofgren 2010; Thome 2006; $\mathrm{N}=180$ ) that the difference in VAS arm pain between iliac crest autograft and a cage is not statistically significant (MD -0.29; 95\% CI -0.90 to 0.33 ).

- VAS neck pain was reported in three studies (Lofgren 2010; Thome 2006; Vavruch 2002; N = 269). The pooled result was highly heterogeneous, so this comparison could not be further analysed.

\section{Other clinical outcome}

- There is moderate quality evidence (high risk of bias) from six studies (Barlocher 2002; Hacker 2000; Lind 2007; Lofgren 2010; Thome 2006; Vavruch 2002; N = 412) that the difference in Odom's criteria between iliac crest autograft and a metal cage is not statistically significant (RR $1.11 ; 95 \%$ CI 0.99 to $1.24 ; \mathrm{P}=$ 0.07; see Figure 5). 
Figure 5. Forest plot of comparison: 5 lliac crest autograft vs cage, outcome: 5.8 Odom's criteria.

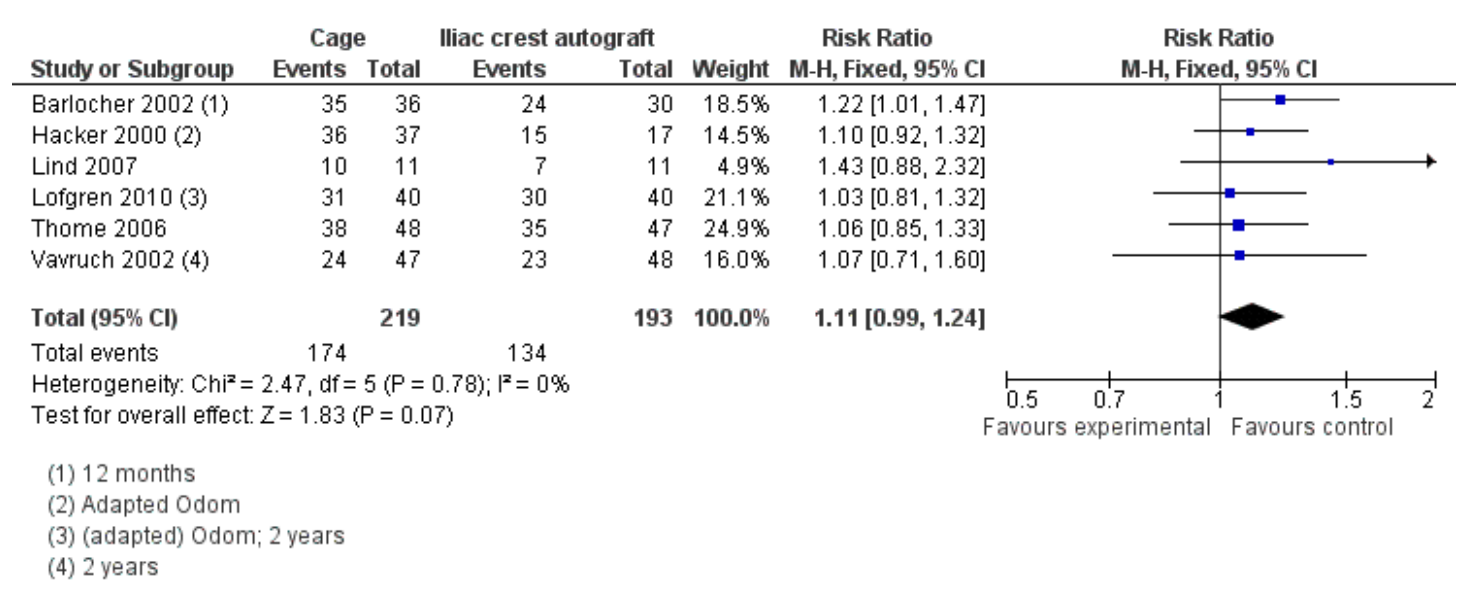

- Neck Disability Index was reported in two studies (Lofgren 2010; Vavruch 2002; $\mathrm{N}=145$ ). The pooled result showed significant heterogeneity, so this comparison could not be further analysed.

\section{Radiological}

- There is low quality evidence (high risk of bias, imprecision) from five studies ( Barlocher 2002; Hacker 2000; Lofgren 2010; Thome 2006; Vavruch 2002; N = 424) that iliac crest autograft is more effective in achieving fusion than a cage (OR $1.87 ; 95 \%$ CI 1.10 to 3.17 ; $\mathrm{P}=0.02$ ).

\section{Complications}

- There is low quality evidence (high risk of bias, imprecision) from seven studies (Barlocher 2002; Celik 2007; Hacker 2000; Lind 2007; Lofgren 2010; Thome 2006; Vavruch 2002; N = 889) that cages are more effective in preventing complications than iliac crest autograft (OR $0.32 ; 95 \%$ CI 0.11 to $0.92 ; \mathrm{P}=$ 0.03; see Figure 3). In the iliac crest autograft group, there were 11 complications (7 re-operations, 2 hematoma, 1 iliac crest fracture, 1 Horner syndrome) and in the cage group, there were three complications (2 re-operations, 1 Horner syndrome).

\section{6. lliac crest autograft vs iliac crest autograft with plates}

Three small studies (Savolainen 1998; Xie 2007; Zoega 2000; N = 136) compared autograft $(\mathrm{N}=67)$ with autograft and anterior plating $(\mathrm{N}=69)$.

Savolainen 1998 compared fusion with autograft with or without $(\mathrm{N}=60)$ additional plating. Zoega 2000 compared fusion with autograft with or without $(\mathrm{N}=46)$ additional plate fixation. Xie
2007 compared iliac crest autograft with or without an anterior plate $(\mathrm{N}=30)$.

Zoega 2000 concluded that the clinical benefits of plate fixation were minimal, although they found more improvement in arm pain in patients with two-level degeneration treated with a plate than in those treated without a plate. Xie 2007 did not conclude there was any difference between iliac crest autograft and anterior plating, but their study was more focused on the comparison with the discectomy group.

Two studiesmet $50 \%$ of the risk of bias assessment criteria (Savolainen 1998; Xie 2007); but only Xie 2007 used a valid randomisation technique. Both studies are regarded as having high risk of bias. Zoega 2000 met 10 of 12 items and included a valid randomisation technique and allocation concealment and could be regarded as a study with low risk of bias.

Xie 2007 reported SF-36 and McGill Pain Scale scores in graphs, which did not permit data extraction. Zoega 2000 reported pain scores, but we were unable to calculate an overall pain score because only median scores were given for subgroups.

In summary, between those who received iliac crest autograft and those who received iliac crest autograft with a plate, there is very low quality evidence that the difference in clinical outcomes is not statistically significant (2 RCT, 106 participants, RR 1.14; 95\% CI 0.91 to 1.41 ). There is low quality evidence from two studies $\mathrm{N}=90$ ) that the difference in fusion is not statistically significant (2 RCT, 90 participants, RR 0.99; 95\% CI 0.92 to 1.07). There is moderate quality evidence that the difference in complication rate is not statistically significant (3 RCT, 136 participants). 
- There were no studies that compared iliac crest autograft with iliac crest autograft and anterior plates that adequately reported pain.

\section{Other clinical outcome}

- There is very low quality evidence (high risk of bias, imprecision, suspected publication bias) from two studies (Savolainen 1998; Zoega 2000; N = 106) that the difference in clinical outcomes between iliac crest autograft and iliac crest autograft with an anterior plate are not statistically significant (RR 1.14; 95\% CI 0.91 to $1.41 ; \mathrm{P}=0.25$ ).

\section{Radiological}

- There is low quality evidence (high risk of bias, suspected publication bias) from two studies (Savolainen 1998; Xie 2007; $\mathrm{N}=90$ ) that the difference in fusion between iliac crest autograft and iliac crest autograft with an anterior plate is not statistically significant (RR 0.99; 95\% CI 0.92 to $1.07 ; \mathrm{P}=0.76$ ).

\section{Complications}

- There is moderate quality evidence (high risk of bias) from three studies (Savolainen 1998; Xie 2007; Zoega 2000; N = 136) that the difference in complication rate between iliac crest autograft and iliac crest autograft with plates is not statistically significant (see Figure 3). There were six complications in each group. In the plate group, there was 1 reoperation, 3 prolonged iliac crest pain, 1 loosening graft and 1 wound infection; in the discectomy group, there were 3 patients with iliac crest pain, 1 loosening graft and 2 infections.

\section{Different types of autograft}

One small study with high risk of bias (McGuire 1994, met two of 12 items; did not report adequate randomisation or allocation concealment) with 46 patients was found that evaluated different types of autograft. This study concluded that vertebral body graft was not superior to iliac crest autograft. This comparison could not be included in a quantitative analysis.

\section{Allograft vs cages}

One small study with a high risk of bias (Porras-Estrada 2004) compared cylindrical allograft bone $(\mathrm{N}=22)$ with a titanium implant (BAK-C®). This study concluded that there were no clinical differences between titanium cage and cylindrical bone, but that the cylindrical titanium cage provided better interspace height, interspace angulation and fusion rate. The study met six items during the risk of bias assessment, but did not report a valid randomisation technique or allocation concealment. The study is thus regarded as high risk of bias. This comparison could not be included in a quantitative analysis.

\section{Other comparisons between different types of instrumentation}

Nine small studies compared different types of instrumentation. Two small studies with high risk of bias (inadequate randomisation or allocation concealment; $\mathrm{N}=101$ ) compared allograft with plate $(\mathrm{N}=53)$ versus cage $(\mathrm{N}=48)$. Fernandez-Fairen 2008 compared a porous Trabecular Metal interbody cage with a semiconstrained rotational plate (Alpha plate, $\mathrm{N}=61$ ). Ryu 2006 compared an anterior plate (DOC ${ }^{\mathrm{TM}}$ or PEAK ${ }^{\mathrm{TM}}$ Poyaxial) with a cervical I/F cage $(\mathrm{N}=40)$. Fernandez-Fairen 2008 concluded that there were no clinical differences, but that the cage prevented donor site harvesting and plate complications. Ryu 2006 concluded that there were no differences between the two treatment options with regard to clinical outcome or complications. Both studies met seven of 12 items; only Fernandez-Fairen 2008 applied a valid randomisation technique, but neither concealed the allocation. Therefore, both studies had high risk of bias. Ryu 2006 had more than 20\% missing data for all parameters on all follow-up moments, so these data were not included. The study also only reported SF-36 results in graphs, which did not permit data extraction. This left only one study with a high risk of bias in the comparison; therefore, this comparison could not be included in a quantitative analysis.

Two small studies with high risk of bias compared PMMA versus a cage $(\mathrm{N}=169)$. Barlocher 2002 compared PMMA with Bak/ C® with Tutuoplast $(\mathrm{N}=62)$. Schroder 2007 compared PMMA (Palacos(R)) with Intromed ZWE intervertebral spacer $(\mathrm{N}=107)$. Barlocher 2002 concluded that PMMA is a good alternative for an interbody fusion cage, but is hindered by the absence of immediate fusion. Schroder 2007 concluded that there were no clinical differences, but that a titanium cage provided a better fusion rate than PMMA bone cement. Both studies met six or seven items on the risk of bias assessment, but only Schroder 2007 had a valid randomisation technique. Therefore, both studies have high risk of bias. Barlocher 2002 only reported percentage of improvement for arm and neck pain.

In summary, between those who received PMMA cement and those who received a cage, there is low quality evidence that the difference in improving Odom's criteria is not statistically significant (2 RCT, 169 participants, RR 1.00; 95\% CI 0.85 to 1.19 ).

\section{Pain}

- There were no RCTs comparing PMMA with cage that adequately reported pain.

\section{Other clinical outcome}

- There is low quality evidence (high risk of bias, imprecision) from two studies (Barlocher 2002; Schroder 2007; $\mathrm{N}=169$ ) that the difference between PMMA and cage in improving Odom's criteria is not statistically significant (RR $1.00 ; 95 \%$ CI 0.85 to $1.19 ; \mathrm{P}=0.96$ ). 


\section{Radiological}

- 'No fusion' was reported in both studies, but showed significant heterogeneity and could not be further analysed.

\section{Complications}

- There were no serious complications reported in both studies.

Two small studies with high risk of bias (Nunley 2009; Stulik 2007; $N=198)$ compared dynamic anterior plates $(N=102)$ with static anterior plates $(\mathrm{N}=96)$. Nunley 2009 compared a dynamic with a static $(\mathrm{N}=66)$ CTEK plate. Stulik 2007 compared a dynamic ABC plate with a rigid CSLP plate $(\mathrm{N}=132)$. Nunley 2009 concluded that there were no significant differences for single-level fusions, but that multi-level fusions had a better clinical outcome with dynamic plates. Stulik 2007 concluded that dynamic plates resulted in faster fusion with fewer complications. Only Nunley 2009 used a valid randomisation technique, but no allocation concealment. Therefore, both studies have a high risk of bias. Stulik 2007 had more than 20\% loss of follow-up and could not be included further in the analysis. This left only one study with a high risk of bias in the comparison and therefore, this comparison could not be included in a quantitative analysis.

One small study with high risk of bias $(\mathrm{N}=50)$ compared the use of platelet versus no platelet $(\mathrm{N}=50)$; Feiz-Erfan 2007 concluded that there was no difference between the two treatments. This comparison could not be included in a quantitative analysis.

Two small studies with high risk of bias (Dai 2008; Nabhan 2007) compared a cage versus cage and plate. Dai 2008 compared PEEK or a carbon fibre cage with or without additional plate fixation $(\mathrm{N}=62)$. Nabhan 2007 compared Solis cage with Solis cage and Caspar plate $(\mathrm{N}=37)$. Dai 2008 compared carbon fibre or PEEK cage with cage and plate $(\mathrm{N}=62)$. Nabhan 2007 concluded that there were no significant differences between the two groups. Dai 2008 concluded that there were no clinical differences, but that the fusion rate in the plate group was faster. Dai 2008 only reported arm and neck pain in graphs, which did not permit data extraction. In summary, between those who received a cage and those who received a cage with additional anterior plate, there was very low quality evidence that there was no statistically significant difference in post-operative JOA score (1 RCT, 62 participants, MD 0.50; $95 \%$ CI -0.65 to 1.65 ) or segmental lordosis (1 RCT, 62 participants, MD $-0.60 ; 95 \% \mathrm{CI}-2.95$ to $1.75 ; \mathrm{P}=0.62$ ).

\section{Pain}

- There is very low quality evidence (high risk of bias, nongeneralisable, suspected publication bias) from one study (Nabhan 2007) that plates are more effective for arm pain relief at 24 months. The authors did not find a significant difference in their analyses, probably because they could control for other variables in their own data set. Therefore, re-analysis of these data is not indicated.

- There is very low quality evidence (high risk of bias, nongeneralisable, suspected publication bias) from one study (Nabhan 2007) that cages are more effective for neck pain relief at 24 months. The authors did not find a significant difference in their analyses, probably because they could control for other variables in their own data set. Therefore, re-analysis of these data is not indicated.

\section{Other clinical outcome}

- There is very low quality evidence (high risk of bias, nongeneralisable, suspected publication bias) from one study with high risk of bias (Dai 2008), that the difference in postoperative JOA score between cages and cages with an additional plate is not statistically significant (MD 0.50; $95 \%$ CI -0.65 to 1.65 ; $\mathrm{P}=$ $0.39)$.

\section{Radiological}

- There is very low quality evidence (high risk of bias, nongeneralisable, suspected publication bias) from one study with high risk of bias (Dai 2008), that the difference in segmental lordosis between cages and cages with an additional plate is not statistically significant (MD $-0.60 ; 95 \%$ CI -2.95 to 1.75 ; $\mathrm{P}=$ $0.62)$.

\section{Complications}

- There were no serious complications reported in either studies.

One small study with high risk of bias (Pan 2005) compared screws and graft with anterior plate. This study concluded that an anterior plate provides a better outcome. This study had more than $20 \%$ loss to follow-up and poor data presentation, so this study could not be further included in the analysis.

\section{I S C US I I N}

\section{Update}

This update included 19 new studies. Remarkably, all new studies evaluated the use of instrumentation such as anterior plates for fusion. In this update, we adapted the Cochrane Back Review group recommendations for risk of bias in a trial, which is based on a trial meeting a minimal of $50 \%$ of the risk of bias items. This differs from our previous criteria for a study with high internal validity, when only valid randomisation and allocation concealment techniques were required. In this update, we combined the two criteria, so studies had to meet $50 \%$ of the criteria, including a positive 
score on the items for randomisation and allocation concealment. With the new criteria, fewer studies have a low risk of bias.

\section{Clinical}

None of the evidence from this systematic review indicates that any technique results in (clinically relevant) better pain relief for patients with chronic cervical degenerative disc disease or disc herniation compared to another technique. The choice for a specific technique cannot be made on the most important aspect, pain relief, which was the primary outcome parameter in our review. This is in agreement with Carragee 2008, who could not find scientific support for invasive interventions in patients with isolated neck pain. For patients with radiculopathy, they found no treatment to be superior. Other important considerations in the choice for surgical technique are complication rate, other clinical outcomes and fusion rate.

When looking at complications, cages perform better than iliac crest graphs. The difference is clinically significant. Other comparisons between complication rates did not show statistically significant differences. However, we must be aware that these trials are not powered to identify a difference in the occurrence of complication rates, which have a low incidence. Also, the aggregate of studies might still fall short of adequate power.

When looking at other clinical outcomes, discectomy was more effective than human bone graft in improving return-to-work at five weeks, but the effect was small and unstable and at 10 weeks the difference was not statistically significant. For all other analyses of clinical parameters, none of the evidence from this review indicates that there is a statistical difference between any of the techniques. Fusion rate is important because it is the key in the working mechanism of many of the surgical techniques. When looking at fusion rates, iliac crest autograft is the best treatment for preventing nonfusion, as it performs better (clinically and statistically) than discectomy alone and cages. As for the other surgical techniques, we could not find any differences of fusion rates between discectomy plus cages or PMMA, discectomy alone, iliac crest autograft plus an anterior plate or iliac crest autograft. This is in contradiction to the meta-analysis by Fraser 2007, who found better fusion rates for anterior plates. The meta-analysis included retrospective, noncontrolled, studies, which may be prone to bias. As for discectomy, the intended working mechanism does not involve fusion of the motion segment, so lower fusion rates compared to iliac crest autograft may have no clinical implications.

\section{Methodology}

The small sample sizes of the studies make it hard to draw conclusions about the absence of differences, especially when only one study is found or when combined studies have a wide range of uncertainty.
To be regarded as a randomised controlled trial, the randomisation technique should be valid, applied just before the treatment is given and have an unpredictable allocation. There are several techniques to keep the allocation unpredictable, such as sealed envelopes or a telephone call to the research centre. Invalid randomisation procedures will produce unbalanced groups by confounding by indication. We excluded studies based only on randomisation technique when it was apparent that the technique used was not valid and could introduce confounding by indication. When in doubt, we kept the trial in the review, which was the case in seven of the 17 trials. These trials might have used an invalid method of randomisation that could have distorted our results. A sensitivity analysis was not possible because of the limited number of comparable outcome parameters.

Blinding is hard to achieve in orthopedic surgical trials, especially for the surgeon. However, for the outcome assessor, it is possible to use independent observers who have no knowledge of the applied treatment. Blinding of the outcome assessor was only used in three studies.

There appears to be a range of outcome scores considered relevant in the assessment of the results of cervical interbody fusion. In essence, this may be true for each separate trial, but comparison among trials is not possible if each trial uses a different score. Therefore, in the setup of a trial it is essential to go beyond the question at hand and also look at the wider picture. There appears to be little consensus on the use of specific outcome parameters in orthopedic surgery. If inferences are wanted from separate studies published in the literature, guidelines for the use of standard scales have to be developed by the orthopedic community (Pietrobon 2002). Therefore, the use of standard scales has been promoted (Pietrobon 2002) and includes patient disability and impairment scores such as the SF-36 and Neck Disability Index. In our opinion, study-specific outcome parameters should be accompanied by general global patient parameters in each dimension of outcome, i.e. pain (VAS neck and VAS arm), functional (WOMAC, NDI), societal (satisfaction/Odom's criteria, working capacities, SF-36), radiological (fusion), and complications. Outcomes should also be reported at standard outcome intervals.

\section{Reporting}

An in-depth and systematic review of the published literature requires this literature to be complete and consistent with the presentation of its data. This is certainly not the case in the studies found for this review. For the primary outcome parameter, pain, results were reported either as mean, mean improvement or percentage of the patients that showed a specific improvement. Further, the description of the methodology could be improved. A mention of allocation concealment in the randomisation technique is essential.

A second issue is the formation of homogeneous groups. In this review, it was very difficult to find comparable patient groups across 
studies. Many groups differed in diagnosis because of different selection criteria. Another essential element when identifying specific subgroups, is to also provide separate data and analyses for each group. This can be applied to different diagnostic groups, such as, patients with radiculopathy, myelopathy, etc and also for different treatment groups such as single- or double-level surgery. From that aspect, we should mention that the goal of this review was changed from single-level to single- and double-level procedures, because of the limited number of studies that included only single-level procedures.

\section{A U THORS' CONCLUSIONS}

\section{Implications for practice}

For reduction of pain in patients with cervical degenerative disc disease or disc herniation, we found no superior treatment. The literature is hampered by few studies, small studies, and generally poor research design. Consequently, it is unclear what patients, if any, benefit from cervical fusion as opposed to discectomy alone. In most studies and for most outcomes, discectomy was not statistically different from fusion by any technique, and there are no clear differences among fusion techniques. This review showed that the only evidence-based choice is between iliac crest autograft and cages for chronic cervical degenerative disc disease. This choice depends on balancing the importance of improved fusion rates with autograft versus improved complication rate with cages. As the relationship between clinical parameters and fusion rates remains weak, cages are a valid alternative for iliac crest autograft, although the working mechanism of fusion might not apply for isolated nerve root compression. The results are likely to be influenced by future research.

\section{Implications for research}

More methodologically rigorous studies are needed In the field of surgical treatment of cervical degenerative disc disease before evidence-based recommendations on this topic can be made. The methodological quality of the design of the studies would be improved by standardizing the outcome parameters and follow-up time-points. Also, more long-term outcome data (i.e. 10 years) are needed. Presentation of the data could be improved by describing the randomisation technique, the selection criteria, the population and study participants. Results should be given for every identifiable subgroup, with appropriate identification of variation. These implications have improved slightly since our previous version of this review, but still need attention. Additional instrumentation such as screws, plates, and cages should be compared against discectomy with or without autograft before any other comparisons are undertaken.

\section{ACKNOWLEDGEMENTS}

We would like to thank the Cochrane Back Review Group for their help in the literature search, the pre-selection by Rachel Couban (RC), and their help during the review process. Thanks to Miao Fang for the assessment of one Chinese article (Pan 2005) and to Tomasz Kotwicki for assessment of one Polish article (Pasciak 2005).

\section{REFERENCES}

\section{References to studies included in this review}

Abd-Alrahman 1999 \{published data only\}

* Abd-Alrahman N, Dokmak AS, Abou-Madawi A. Anterior cervical discectomy (ACD) versus anterior cervical fusion (ACF), clinical and radiological outcome study. Acta Neurochirgica (Wien) 1999;141(10):1089-92.

Barlocher 2002 \{published data only\}

Barlocher CB, Barth A, Krauss JK, Binggeli R, Seiler RW. Comparative evaluation of microdiscectomy only, autograft fusion, polymethyl-methacrylate interposition, and threaded titanium cage fusion for treatment of singlelevel cervical disc disease: a prospective randomized study in 125 patients. Neurosurgical Focus 2002;12(1):E4.

Baskin 2003 \{published data only\}

* Baskin DS, Ryan P, Sonntag V, Westmark R, Widmayer MA. A prospective, randomized, controlled cervical fusion study using recombinant human bone morphogenetic protein-2 with the CORNERSTONE-SR allograft ring and the ATLANTIS anterior cervical plate. Spine 2003;28(12): 1219-25.

\section{Celik 2007 \{published data only\}}

* Celik SE, Kara A, Celik S. A comparison of changes over time in cervical foraminal height after tricortical iliac graft or polyetheretherketone cage placement following anterior discectomy. Journal of Neurosurgery: Spine 2007;6(1):10-6.

Dai 2008 \{published data only\}

* Dai LY, Jiang LS. Anterior cervical fusion with interbody cage containing beta-tricalcium phosphate augmented with plate fixation: A prospective randomized study with 2-year follow-up. European Spine Journal 2008;17(5):698-705.

Dowd 1999 \{published data only\}

* Dowd GC, Wirth FP. Anterior cervical discectomy: Is fusion necessary?. Journal of Neurosurgery 1999;90(1):8-12. 
Feiz-Erfan 2007 \{published data only\}

* Feiz-Erfan I, Harrigan M, Sonntag VK, Harrington TR. Effect of autologous platelet gel on early and late graft fusion in anterior cervical spine surgery. Journal of Neurosurgery: Spine 2007;7(5):496-502.

Fernandez-Fairen 2008 \{published data only\} * Fernandez-Fairen M, Sala P, Dufoo M Jr, Ballester J, Murcia A, Merzthal L. Anterior cervical fusion with tantalum implant: a prospective randomized controlled study. Spine 2008;33(5):465-72.

\section{Hacker 2000 \{published data only\}}

* Hacker RJ. A randomized prospective study of an anterior cervical interbody fusion device with a minimum of 2 years of follow-up results. Journal of Neurosurgery 2000;93(2 Suppl):222-6.

Hacker RJ. Threaded cages for degenerative cervical disease. Clinical Orthopaedics and Related Research 2002;394:39-46.

\section{Hauerberg 2008 \{published data only\}}

${ }^{*}$ Hauerberg J, Kosteljanetz M, Boge-Rasmussen T, Dons K, Gideon P, Springborg JB, et al.Anterior cervical discectomy with or without fusion with ray titanium cage: a prospective randomized clinical study. Spine 2008;33(5):458-64.

Lind 2007 \{published data only\}

* Lind BI, Zoega B, Rosen H. Autograft versus interbody fusion cage without plate fixation in the cervical spine: a randomized clinical study using radiostereometry. European Spine Journal 2007;16(8):1251-6.

\section{Lofgren 2000 \{published data only\}}

* Lofgren H, Johannsson V, Olsson T, Ryd L, Levander B. Rigid fusion after Cloward operation for cervical disc disease using autograft, allograft, or xenograft: A randomized study with radiostereometric and clinical follow-up assessment. Spine 2000;25(15):1908-16.

\section{Lofgren 2010 \{published data only\}}

Lofgren H, Engquist M, Hoffmann P, Sigstedt B, Vavruch L. Clinical and radiological evaluation of Trabecular Metal and the Smith-Robinson technique in anterior cervical fusion for degenerative disease: a prospective, randomized, controlled study with 2-year follow-up. European Spine Journal 2010;19(3):464-73.

\section{Madawi 1996 \{published data only\}}

* Madawi AA, Powell M, Crockard HA. Biocompatible osteoconductive polymer versus iliac graft. A prospective comparative study for the evaluation of fusion pattern after anterior cervical discectomy. Spine 1996;21(18):2123-9.

\section{Martins 1976 \{published data only\}}

* Martins AN. Anterior cervical discectomy with and without interbody bone graft. Journal of Neurosurgery 1976; 44(3):290-5.

McConnel 2003 \{published data only\}

* McConnell JR, Freeman BJ, Debnath UK, Grevitt MP, Prince HG, Webb JK. A prospective randomized comparison of coralline hydroxyapatite with autograft in cervical interbody fusion. Spine 2003;28(4):317-23.
McGuire 1994 \{published data only\}

* McGuire RA, St. John K. Comparison of anterior cervical fusions using autogenous bone graft obtained from the cervical vertebrae to the modified Smith-Robinson technique. Journal of Spinal Disorders 1994;7(6):499-503.

Nabhan 2007 \{published data only\}

* Nabhan A, Pape D, Pitzen T, Steudel WI, Bachelier F, Jung J, et al.Radiographic analysis of fusion progression following one-level cervical fusion with or without plate fixation. Zentralblatt fur Neurochirurgie 2007;68(3):133-8.

Nunley 2009 \{published data only\}

* Nunley PD, Jawahar A, Kerr EJ III, Cavanaugh DA, Howard C, Brandao SM. Choice of plate may affect outcomes for single versus multilevel ACDF: results of a prospective randomized single-blind trial.. Spine Journal 2009;9(2):121-7.

Oktenoglu 2007 \{published data only\} * Oktenoglu T, Cosar M, Ozer AF, Iplikcioglu C, Sasani M, Canbulat N, et al.Anterior cervical microdiscectomy with or without fusion. Journal of Spinal Disorders \& Techniques 2007;20(5):361-8.

\section{Pan 2005 \{published data only\}}

* Pan SF, Li M, Wang SB, Zhang FS, Sun Y. [A prospective randomized comparison between with or without instrumentation in short-level anterior discectomy and autograft bone fusion]. [Chinese]. Chung-Hua Wai Ko Tsa Chih [Chinese Journal of Surgery] 2005;43(4):218-20.

Porras-Estrada 2004 \{published data only\}

* Porras-Estrada LF, Ugarriza-Echebarrieta LF, LorenzanaHonrado L, Rodriguez-Sanchez JA, Garcia-Yague LM, Fernandez-Portales I, et al.[Anterior cervical interbody fusion with treated cylindrical bone versus BAK-C $($ cage: a comparative study]. [Spanish]. Neurocirugia (Asturias, Spain) 2004;15(3):270-8.

Rosenorn 1983 \{published data only\}

* Rosenorn J, Hansen EB, Rosenorn MA. Anterior cervical discectomy with and without fusion: A prospective study. Journal of Neurosurgery 1983;59(2):252-5.

Ruetten 2009 \{published data only\} Ruetten S, Komp M, Merk H. Full-endoscopic anterior decompression versus conventional anterior decompression and fusion in cervical disc herniations. International Orthopaedics 2009;33:1677-82.

\section{Ryu 2006 \{published data only\}}

* Ryu SI, Mitchell M, Kim DH. A prospective randomized study comparing a cervical carbon fiber cage to the SmithRobinson technique with allograft and plating: Up to 24 months follow-up. European Spine Journal 2006;15(2): 157-64.

Savolainen 1998 \{published data only\}

* Savolainen S, Rinne J, Hernesniemi J. A prospective randomized study of anterior single-level cervical disc operations with long-term follow-up: Surgical fusion is unnecessary. Neurosurgery 1998;43(1):51-5. 
Schroder 2007 \{published data only\}

* Schroder J, Grosse-Dresselhaus F, Schul C, Wassmann H. PMMA versus titanium cage after anterior cervical discectomy - a prospective randomized trial. Zentralblatt fur Neurochirurgie 2007;68(1):2-7.

Stulik 2007 \{published data only\}

* Stulik J, Pitzen TR, Chrobok J, Ruffing S, Drumm J, Sova $\mathrm{L}$, et al.Fusion and failure following anterior cervical plating with dynamic or rigid plates: 6-months results of a multi-centric, prospective, randomized, controlled study. European Spine Journal 2007;16(10):1689-94.

Thome 2006 \{published data only\}

* Thome C, Leheta O, Krauss JK, Zevgaridis D. A prospective randomized comparison of rectangular titanium cage fusion and iliac crest autograft fusion in patients undergoing anterior cervical discectomy. Journal of Neurosurgery: Spine 2006;4(1):1-9.

van den Bent 1996 \{published data only\}

* van den Bent MJ, Oosting J, Wouda EJ, van Acker EH, Ansink BJ, Braakman R. Anterior cervical discectomy with or without fusion with acrylate: A randomized trial. Spine 1996;21(7):834-9.

Vavruch 2002 \{published data only\}

Peolsson A, Hedlund R, Vavruch L. Prediction of fusion and importance of radiological variables for the outcome of anterior cervical decompression and fusion. European Spine Journal 2004;13(3):229-34.

Peolsson A, Hedlund R, Vavruch L, Oberg B. Predictive factors for the outcome of anterior cervical decompression and fusion. European Spine Journal 2003;12(3):274-80. Peolsson A, Vavruch L, Hedlund R. Long-term randomised comparison between a carbon fibre cage and the Cloward procedure in the cervical spine. European Spine Journal 2007;16(2):173-8.

* Vavruch L, Hedlund R, Javid D, Leszniewski W, Shalabi A. A prospective randomized comparison between the Cloward procedure and a carbon fiber cage in the cervical spine: A clinical and radiologic study. Spine 2002;27(16): 1694-701.

Xie 2007 \{published data only\}

* Xie JC, Hurlbert RJ. Discectomy versus discectomy with fusion versus discectomy with fusion and instrumentation: a prospective randomized study. Neurosurgery 2007;61(1): $107-16$

Zoega 2000 \{published data only\}

Zoega B, Karrholm J, Lind B. One-level cervical spine fusion. A randomized study, with or without plate fixation, using radiostereometry in 27 patients. Acta Orthopaedica Scandinavica 1998;69(4):363-8.

* Zoega B, Karrholm J, Lind B. Outcome scores in degenerative cervical disc surgery. European Spine Journal 2000;9(2):137-43.

Zoega B, Karrholm J, Lind B. Plate fixation adds stability to two-level anterior fusion in the cervical spine: A randomized study using radiostereometry. European Spine Journal 1998; 7(4):302-7.

Zoega B, Rosen H, Lind B. Anterior cervical discectomy and fusion with or without plate fixation: A prospective and randomized study. Neuro-Orthopedics 2000;28(1):39-51.

\section{References to studies excluded from this review}

An 1995 \{published data only\}

An HS, Simpson JM, Glover JM, Stephany J. Comparison between allograft plus demineralized bone matrix versus autograft in anterior cervical fusion. A prospective multicenter study. Spine 1995;20(20):2211-16.

\section{Barlocher 2000 \{published data only\}} Barlocher C, Barth A, Binggeli R, Krauss J, Seiler R. Prospective comparative study between no fusion and three spondylodesis methods after cervical discectomy. European Spine Journal 2000;4:299.

Bishop 1996 \{published data only\} Bishop RC, Moore KA, Hadley MN. Anterior cervical interbody fusion using autogeneic and allogeneic bone graft substrate: A prospective comparative analysis. Journal of Neurosurgery 1996;85(2):206-10.

Bolesta 2002 \{published data only\}

Bolesta MJ, Rechtine GR, Chrin AM. One and two-level anterior cervical discectomy and fusion: The effect of plate fixation. Spine Journal 2002;2(3):197-203.

Brown 1976 \{published data only\} Brown MD, Malinin TI, Davis PB. A roentgenographic evaluation of frozen allografts versus autografts in anterior cervical spine fusions. Clinical Orthopaedics and Related Research 1976;119:231-6.

\section{Chen 2001 \{published data only\}}

Chen BH, Natarajan RN, An HS, Andersson GB. Comparison of biomechanical response to surgical procedures used for cervical radiculopathy: Posterior keyhole foraminotomy versus anterior foraminotomy and discectomy versus anterior discectomy with fusion. Journal of Spinal Disorders \& techniques 2001;14(1):17-20.

Dunsker 1977 \{published data only\} Dunsker SB. Anterior cervical discectomy with and without fusion. Clinical Neurosurgery 1977;24:516-21.

Emery 1976 \{published data only\} Emery SE, Bolesta MJ, Banks MA, Jones PK. Robinson anterior cervical fusion comparison of the standard and modified techniques. Spine 1976;19(6):660-3.

Espersen 1984 \{published data only\} Espersen JO, Buhl M, Eriksen EF, Fode K, Klaerke A, Kroyer L, et al.Treatment of cervical disc disease using Cloward's technique. I. General results, effect of different operative methods and complications in 1,106 patients. Acta Neurochirurgica (Wien) 1984;70(1-2):97-114.

Grob 2001 \{published data only\} Grob D, Peyer JV, Dvorak J. The use of plate fixation in anterior surgery of the degenerative cervical spine: A 
comparative prospective clinical study. Spine 2001;10(5): 408-13.

\section{Hedlund 2001 \{published data only\}}

Hedlund R, Vavruch L, Shalabi A, Javid D, Leszniewski W. Low fusion rate with the Brantigan cage in the cervical spine: A prospective randomized study. European Spine Journal 2001;7:S16.

\section{Herkowitz 1990 \{published data only\}}

Herkowitz, N, Kurz LT, Overholt DP. Surgical management of cervical soft disc herniation. A comparison between the anterior and posterior approach. Spine 1990;15(10): 1026-30.

Iseda 2000 \{published data only\}

Iseda T, Nakano S, Suzuki Y, Miyahara D, Uchinokura S, Moriyama T, et al.Radiographic and scintigraphic courses of union in cervical interbody fusion: Hydroxyapatite grafts versus iliac bone autografts. Journal of Nuclear Medicine 2000;41:1642-5.

\section{Iseda 2001 \{published data only\}}

Iseda T, Goya T, Nakano S, Kodama T, Moriyama T, Wakisaka $S$. Serial changes in signal intensities of the adjacent discs on T2-weighted sagittal images after surgical treatment of cervical spondylosis: Anterior interbody fusion versus expansive laminoplasty. Acta Neurochirurgica (Wien) 2001;143(7):707-10.

\section{Jenis 2000 \{published data only\}}

Jenis LG, An HS, Simpson JM. A prospective comparison of the standard and reverse Robinson cervical grafting techniques: Radiographic and clinical analyses. Journal of Spinal Disorders 2000;13(5):369-73.

Jollenbeck 2001 \{published data only\}

Jollenbeck B, Fernandez N, Firsching R. Titanium or polymethylmethacrylate in cervical disc surgery? A prospective study. Zentralblatt fur Neurochirurgie 2001;62 (4):200-2.

Kadanka 2000 \{published data only\}

Kadanka Z, Bednarik J, Vohanka S, Vlach O, Stejskal L, Chaloupka $\mathrm{R}$, et al.Conservative treatment versus surgery in spondylotic cervical myelopathy: A prospective randomised study. European Spine Journal 2000;9(6):538-44.

\section{Lopez-Olivia 1998 \{published data only\}}

* Lopez-Oliva Munoz F, Garcia de las Heras B, Concejero Lopez V, Asenjo Siguero JJ. Comparison of three techniques of anterior fusion in single-level cervical disc herniation. European Spine Journal 1998;7(6):512-6.

\section{Marks 1998 \{published data only\}}

Marks SM. Cervical degenerative disease: discectomy or fusion?. British Journal of Neurosurgery 1998;12(2):109-12.

Mayer 1998 \{published data only\}

Mayer T, McMahon MJ, Gatchel RJ, Sparks B, Wright A, Pegues P. Socioeconomic outcomes of combined spine surgery and functional restoration in workers' compensation spinal disorders with matched controls. Spine 1998;23(5): 598-605.
Murphy 1994 \{published data only\}

Murphy MA, Trimble MB, Piedmonte MR, Kalfas IH. Changes in the cervical foraminal area after anterior discectomy with and without a graft. Neurosurgery 1994;34 (1):93-6.

Pasciak 2005 \{published data only\}

Pasciak M, Grzywocz J, Widuchowski J, Koczy B, Wadek T, Werner K. [Assessment of radiological results of anterior cervical discectomy with different fusion cages]. [Polish]. Chirurgia Narzadow Ruchu i Ortopedia Polska 2005;70(5): 347-51.

\section{Persson 1997 \{published data only\}}

Persson LC, Carlsson CA, Carlsson JY. Long-lasting cervical radicular pain managed with surgery, physiotherapy, or a cervical collar. A prospective, randomized study. Spine 1997;22(7):751-8.

Persson 2001 \{published data only\}

Persson LC, Lilja A. Pain, coping, emotional state and physical function in patients with chronic radicular neck pain. A comparison between patients treated with surgery, physiotherapy or neck collar - a blinded, prospective randomized study. Disability and Rehabilitation 2001;23 (8):325-35.

\section{Rawlinson 1994 \{published data only\}}

Rawlinson JN. Morbidity after anterior cervical decompression and fusion. The influence of the donor site on recovery, and the results of a trial of surgibone compared to autologous bone. Acta Neurochirurgica (Wien) 1994;131 (1-2):106-18.

\section{Rish 1976 \{published data only\}}

Rish BL, McFadden JT, Penix JO. Anterior cervical fusion using homologous bone grafts: a comparative study. Surgical Neurology 1976;5(2):119-21.

\section{Shapiro 2001 \{published data only\}}

Shapiro S, Connolly P, Donnaldson J, Abel T. Cadaveric fibula, locking plate, and allogeneic bone matrix for anterior cervical fusions after cervical discectomy for radiculopathy or myelopathy. Journal of Neurosurgery 2001;95(1 Supp): 43-50.

Shin 2007 \{published data only\}

Shin SH, Lee WJ, Eun JP, Choi HY, Lee JC. Clinical and radiologic assessment for anterior cervical interbody fusion with synthetic cages. Journal of Korean Neurosurgical Society 2007;41(2):105-10.

Siddiqui 2003 \{published data only\} Siddiqui AA, Jackowski A. Cage versus tricortical graft for cervical interbody fusion. A prospective randomised study. Journal of Bone and Joint Surgery (Br) 2003;85(7):1019-25.

\section{Suchomel 2004 \{published data only\}}

Suchomel P, Barsa P, Buchvald P, Svobodnik A, Vanickova E. Autologous versus allogenic bone grafts in instrumented anterior cervical discectomy and fusion: a prospective study with respect to bone union pattern. European Spine Journal 2004;13(6):510-5. 
Theodore 2000 \{published data only\}

Theodore N, Sonntag VKH. Spinal surgery: The past century and the next. Neurosurgery 2000;46(4):767-77.

Watters 1994 \{published data only\}

Watters 3rd WC, Levinthal R. Anterior cervical discectomy with and without fusion. Results, complications, and longterm follow-up. Spine 1994;19(20):2343-7.

Wigfield 2001 \{published data only\}

Wigfield CC, Nelson RJ. Nonautologous interbody fusion materials in cervical spine surgery: How strong is the evidence to justify their use?. Spine 2001;26(6):687-694.

Wigfield 2002 \{published data only\} Wigfield C, Gill S, Nelson R, Langdon I, Metcalf N, Robertson J. Influence of an artificial cervical joint compared with fusion on adjacent-level motion in the treatment of degenerative cervical disc disease. Journal of Neurosurgery 2002;96(1 Supp):17-21.

Wigfield 2003 \{published data only\} Wigfield C, Robertson J, Gill S, Nelson R. Clinical experience with porous tantalum cervical interbody implants in a prospective randomized controlled trial. Brittish Journal of Neurosurgery 2003;17(5):418-25.

Wirth 2000 \{published data only\}

Wirth FP, Dowd GC, Sanders HF, Wirth C. Cervical discectomy. A prospective analysis of three operative techniques. Surgical Neurology 2000;53:340-6.

Yamamoto 1978 \{published data only\} Yamamoto I, Kurokawa K, Tew, M, Dunsker SB, Mayfield FH. Anterior cervical discectomy with and without fusion clinical and experimental study. No Shinkei Geka 1978;6 (8):781-7.

\section{References to studies awaiting assessment}

\section{Nabhan 2009 \{published data only\}}

Nabhan A, Ishak B, Steimer O, Zimmer A, Pitzen T, Steudel WI, et al.Comparison of bioresorbable and titanium plates in cervical spinal fusion: early radiologic and clinical results. Journal of Spinal Disorders \& Techniques 2009;22 (3):155-61.

Pitzen 2009 \{published data only\}

Pitzen TR, Chrobok J, Stulik J, Ruffing S, Drumm J, Sova L, et al.Implant complications, fusion, loss of lordosis, and outcome after anterior cervical plating with dynamic or rigid plates: two-year results of a multi-centric, randomized, controlled study. Spine 2009;34(7):641-6.

\section{Additional references}

Atkins 2004

Atkins D, Best D, Briss PA, Eccles M, Falck-Ytter Y, Flottorp S, GRADE Working Group. Grading quality of evidence and strength of recommendations. British Medical Journal 2004;328(7454):1490.

\section{Blettner 1999}

Blettner M, Sauerbrei W, Schlehofer B, Scheuchenpflug T, Friedenreich C. Traditional reviews, meta-analyses and pooled analyses in epidemiology. International Journal of Epidemiology 1999;28(1):1-9.

Boselie 2010

Boselie A, van Mameren H, de Bie R, Benzel EC, Willems PC. Fusion versus arthroplasty in single level cervical degenerative disc disease. Cochrane Database of Systematic Reviews 2011, Issue (in editorial process).

\section{Carragee 2008}

Carragee EJ, Hurwitz EL, Cheng I, Carroll LJ, Nordin M, Guzman J, et al.Treatment of neck pain: injections and surgical interventions: results of the Bone and Joint Decade 2000-2010 Task Force on Neck Pain and Its Associated Disorders. Spine 2008;33(4 Suppl):S153-69.

\section{Cloward 1956}

Cloward RB. The anterior approach for removal of ruptured cervical disks. The anterior approach for removal of ruptured cervical disks. Journal of Neurosurgery 1956;15(6): 602-17.

Emery 1994

Emery SE, Bolesta MJ, Banks MA, Jones PK. Robinson anterior cervical fusion comparison of the standard and modified techniques. Spine 1994;19(6):660-3.

Espine Website 2010

Pashman R. E-Spine; Anterior Cervical Fusion. http:// www.espine.com/anterior-cervical-fusion.htm [Accessed May 10, 2010].

Floyd 2000

Floyd T, Ohnmeiss D. A meta-analysis of autograft versus allograft in anterior cervical fusion. Europan Spine Journal 2000;9(5):398-403.

Fraser 1995

Fraser RD. Interbody, posterior, and combined lumbar fusions. Spine 1995;20(24 Suppl):167S-177S.

Fraser 2007

Fraser JF, Härtl R. Anterior approaches to fusion of the cervical spine: a meta-analysis of fusion rates. Journal of Neurosurgery: Spine 2007;6(4):298-303.

Furlan 2009

Furlan A, Pennick V, Bombardier C, van Tulder M. 2009 Updated method guidelines for systematic reviews in the Cochrane Back Review Group. Spine 2009; Vol. 34, issue 18:1929-41.

Greenhalgh 1999

Greenhalgh T. How to read a paper. The basics of evidence based medicine. London: BMJ Publishing group, 1999.

\section{Grob 1998}

Grob D. Surgery in the degenerative cervical spine. Spine 1998;23(24):2674-83.

\section{Heneghan 2009}

Heneghan HM, McCabe JP. Use of autologous bone graft in anterior cervical decompression: morbidity \& quality of life analysis. BMC Musculoskeletal Disorders 2009;10:158. 


\section{Offringa 1999}

Offringa M, de Craen AJ. De praktijk van systematische reviews. I. Inleiding. Nederlands Tijdschrift voor Geneeskunde 1999;143(13):653-6.

\section{Ostelo 2008}

Ostelo RW, Deyo RA, Stratford P, Waddell G, Croft P,

Von Korff M, et al.Interpreting change scores for pain and functional status in low back pain: towards international consensus regarding minimal important change. Spine 2008;33(1):90-4.

\section{Pietrobon 2002}

Pietrobon R, Coeytaux RR, Carey TS, Richardson WJ, DeVellis RF. Standard scales for measurement of functional outcome for cervical pain or dysfunction: A systematic review. Spine 2002;27(5):515-22.

\section{Radhakrishnan 1994}

Radhakrishnan K, Litchy WJ, O'Fallon WM, Kurland LT. Epidemiology of cervical radiculopathy. A population-based study from Rochester, Minnesota, 1976 through 1990. Brain 1994;117:325-35.

Salemi 1996

Salemi G, Savettieri G, Meneghini F, Di Benedetto ME, Ragonese P, Morgante L, et al.Prevalence of cervical spondylotic radiculopathy: a door-to-door survey in a Sicilian municipality. Acta Neurologica Scandinavica 1996; 93(2-3):184-8

\section{Savolainen 1994}

Savolainen S, Usenius JP, Hernesniemi J. Iliac crest versus artificial bone grafts in 250 cervical fusions. Acta
Neurochirgica (Wien) 1994;129(1-2):54-7.

Vaccaro 2003

Vaccaro AR, Singh K, Haid R, Kitchel S, Wuisman P, Taylor $\mathrm{W}$, et al.The use of bio-absorbable implants in the spine. Spine Journal 2003;3(3):227-37.

\section{Whitecloud 1999}

Whitecloud III TS. Modern alternatives and techniques for one-level discectomy and fusion. Clinical Orthopaedics and Related Research 1999;359:67-76.

\section{Young 1993}

Young WF, Rosenwasser RH. An early comparative analysis of the use of fibular allograft versus autologous iliac crest graft for interbody fusion after anterior cervical discectomy. Spine 1993;18(9):1123-4.

\section{References to other published versions of this review}

\section{Jacobs 2004}

Jacobs WCH, Anderson PG, Limbeek J, Willems PC, Pavlov P. Single or double-level anterior interbody fusion techniques for cervical degenerative disc disease. Cochrane Database of Systematic Reviews 2004, Issue 4. [DOI: 10.1002/14651858.CD004958]

van Limbeek 2000 van Limbeek J, Jacobs WC, Anderson PG, Pavlov PW. A systematic literature review to identify the best method for a single level anterior cervical interbody fusion. European Spine Journal 2000;9(2):129-36.

* Indicates the major publication for the study 
CHARACTERISTICS OF STUDIES

Characteristics of included studies [ordered by study ID]

Abd-Alrahman 1999

\begin{tabular}{ll}
\hline Methods & RCT, method unclear \\
\hline Participants & $\begin{array}{l}\text { 1 or } 2 \text { level symptomatic disc disease refractory to conservative treatment } \\
\text { Exclusion: multilevel disease, PLL ossification, re-operations, requiring instrumentation }\end{array}$ \\
\hline Interventions & $\begin{array}{l}\text { 1: Discectomy with Smith and Robinson } \\
\text { 2: Discectomy with Smith and Robinson and fusion with iliac crest autograft }\end{array}$ \\
\hline Outcomes & $\begin{array}{l}\text { Radiological: Kyphose } \\
\text { Clinical: VAS - neck, arm, iliac crest donor site pain }\end{array}$ \\
\hline Notes & $\begin{array}{l}\text { Diagnosis DD: Spondylosis (narrow disc space, sclerosed disc margins, osteophytes) on } \\
\text { plain Radiograph } \\
\text { Cause of pain: radiculopathy, myelopathy } \\
\text { Levels: } 70 / 90 \text { (78\%) one level; } 20 / 90 \text { (22\%) two level }\end{array}$ \\
\hline
\end{tabular}

\section{Risk of bias}

\begin{tabular}{l|l|l}
\hline Item & Authors' judgement & Description \\
\hline Adequate sequence generation? & Unclear & The randomisation technique was not described. \\
\hline $\begin{array}{l}\text { Allocation concealment? } \\
\text { Blinding? }\end{array}$ & Unclear & not described \\
\hline $\begin{array}{l}\text { All outcomes - patients? } \\
\text { Blinding? } \\
\text { All outcomes - outcome assessors? }\end{array}$ & No & \\
\hline $\begin{array}{l}\text { Blinding? } \\
\text { All outcomes - care provider? }\end{array}$ & No & Not possible in surgical procedures \\
\hline
\end{tabular}

Incomplete outcome data addressed? Yes

All outcomes - drop-outs?

Incomplete outcome data addressed? Yes

All outcomes - ITT analysis?

\begin{tabular}{lll}
\hline Free of selective reporting? & Unclear & $\begin{array}{l}\text { Results for arm and neck pain with VAS scores are not presented. } \\
\text { The results are not split for one or two level procedures }\end{array}$ \\
\hline Similarity of baseline characteristics? & Unclear & Unclear from text
\end{tabular}


Abd-Alrahman 1999 (Continued)

\begin{tabular}{ll}
\hline Co-interventions avoided or similar? & Yes \\
\hline Compliance acceptable? & Yes \\
\hline Timing outcome assessments similar? & Yes \\
\hline
\end{tabular}

\section{Barlocher 2002}

\begin{tabular}{|c|c|c|}
\hline Methods & \multicolumn{2}{|l|}{ RCT, Method unclear } \\
\hline Participants & \multicolumn{2}{|c|}{$\begin{array}{l}\text { Inclusion: Cervicobrachialgia, Single level disc disease C3-T1, Radiculopathy d/t HNP/ } \\
\text { osteophytes } \\
\text { Exclusion: Vertebral instability, Myelopathy, Systemic infection or metabolic disease, } \\
\text { Active malignancy, Symptomatic DDD } 2>\text { segments, Acute trauma, RA }\end{array}$} \\
\hline Interventions & \multicolumn{2}{|l|}{$\begin{array}{l}\text { 1: Discectomy alone } \\
\text { 2: Iliac crest autograft }\end{array}$} \\
\hline Outcomes & \multicolumn{2}{|c|}{$\begin{array}{l}\text { Radiological: Flexion extension radiographs, CT } \\
\text { Clinical: VAS, Op time, Blood loss, Odom } \\
\text { Functional: - }\end{array}$} \\
\hline Notes & \multicolumn{2}{|c|}{$\begin{array}{l}\text { Diagnosis DD: MRI } \\
\text { Cause of pain: Radiculopathy } \\
\text { Levels: } 125(100 \%) \text { one level }\end{array}$} \\
\hline \multicolumn{3}{|l|}{ Risk of bias } \\
\hline Item & Authors' judgement & Description \\
\hline Adequate sequence generation? & Unclear & Not described \\
\hline Allocation concealment? & Unclear & not described \\
\hline $\begin{array}{l}\text { Blinding? } \\
\text { All outcomes - patients? }\end{array}$ & Unclear & not possible \\
\hline $\begin{array}{l}\text { Blinding? } \\
\text { All outcomes - outcome assessors? }\end{array}$ & Unclear & not mentioned \\
\hline $\begin{array}{l}\text { Blinding? } \\
\text { All outcomes - care provider? }\end{array}$ & Unclear & not possible \\
\hline $\begin{array}{l}\text { Incomplete outcome data addressed? } \\
\text { All outcomes - drop-outs? }\end{array}$ & Yes & 2 missed to follow up \\
\hline
\end{tabular}


Barlocher 2002 (Continued)

\begin{tabular}{l|ll}
\hline $\begin{array}{l}\text { Incomplete outcome data addressed? } \\
\text { All outcomes - ITT analysis? }\end{array}$ & Yes & implant present, no crossovers \\
\hline Free of selective reporting? & No & Only change percentages reported \\
\hline Similarity of baseline characteristics? & Yes & ok \\
\hline Co-interventions avoided or similar? & Yes & implants or material inside \\
\hline Compliance acceptable? & Yes & similar \\
\hline Timing outcome assessments similar? & Yes &
\end{tabular}

\section{Baskin 2003}

\begin{tabular}{ll}
\hline Methods & RCT, method unclear \\
\hline Participants & 1 or 2 level cervical disc disease, radiculopathy, myelopathy or both \\
\hline Interventions & $\begin{array}{l}\text { Discectomy and fusion with allograft ring and anterior plate } \\
\text { 1: Allograft ring filled with iliac crest Autograft } \\
\text { 2: Allograft ring filled with rhBMP-2 }\end{array}$ \\
\hline Outcomes & $\begin{array}{l}\text { Radiological: Flexion-extension X-rays, CT } \\
\text { Clinical: neurologic status, neck, arm, and donor site pain } \\
\text { Functional: Neck Disability index, SF-36, patient satisfaction }\end{array}$ \\
\hline Notes & $\begin{array}{l}\text { Diagnosis DD: imaging studies: herniated disc and/or osteophyte } \\
\text { Cause of pain: radiculopathy, myelopathy or both } \\
\text { Levels: } 18 / 33 \text { (55\%) one level; } 15 / 33 \text { (45\%) two level }\end{array}$ \\
\hline
\end{tabular}

\section{Risk of bias}

\begin{tabular}{l|l|l}
\hline Item & Authors' judgement & Description \\
\hline Adequate sequence generation? & Unclear & The randomisation technique was not described \\
\hline Allocation concealment? & Unclear & Not described \\
\hline $\begin{array}{l}\text { Blinding? } \\
\text { All outcomes - patients? }\end{array}$ & No & \\
\hline $\begin{array}{l}\text { Blinding? } \\
\text { All outcomes - outcome assessors? }\end{array}$ & No & Not possible in surgical procedures \\
\hline $\begin{array}{l}\text { Blinding? } \\
\text { All outcomes - care provider? }\end{array}$ & No & \\
\hline
\end{tabular}


Baskin 2003 (Continued)

\begin{tabular}{l|l|l}
\hline $\begin{array}{l}\text { Incomplete outcome data addressed? } \\
\text { All outcomes - drop-outs? }\end{array}$ & No & there is considerable lost to follow-up at 12 and 24 months. \\
\hline $\begin{array}{l}\text { Incomplete outcome data addressed? } \\
\text { All outcomes - ITT analysis? }\end{array}$ & Yes & results of One and two-level surgeries were combined \\
\hline Free of selective reporting? & Unclear & \\
\hline Similarity of baseline characteristics? & Yes & Yes \\
\hline Co-interventions avoided or similar? & Yes \\
\hline Compliance acceptable? & Yes \\
\hline Timing outcome assessments similar?
\end{tabular}

Celik 2007

\begin{tabular}{|c|c|c|}
\hline Methods & \multicolumn{2}{|l|}{ RCT, methods unclear } \\
\hline Participants & \multicolumn{2}{|c|}{$\begin{array}{l}\text { Severe radiculopathy } \\
\text { Physiotherapy or analgesics failed }\end{array}$} \\
\hline Interventions & \multicolumn{2}{|c|}{$\begin{array}{l}\text { 1: Discectomy and fusion with PEEK cage } \\
\text { 2: Discectomy and fusion with Smith and Robinson Iliac crest autograft }\end{array}$} \\
\hline Outcomes & \multicolumn{2}{|c|}{$\begin{array}{l}\text { Radiological: Foraminal height, Interspace height, Cobb angle } \\
\text { Clinical: VAS arm, VAS neck } \\
\text { Functional: JOA }\end{array}$} \\
\hline Notes & \multicolumn{2}{|c|}{$\begin{array}{l}\text { Diagnosis DD: Radiculopathy } \\
\text { Cause of pain: Radiculopathy } \\
\text { levels: } 43 / 65 \text { (66\%) one level; } 22(34 \%) \text { two level }\end{array}$} \\
\hline \multicolumn{3}{|l|}{ Risk of bias } \\
\hline Item & Authors' judgement & Description \\
\hline Adequate sequence generation? & Unclear & $\begin{array}{l}\text { "The groups were matched" “... randomised by the first author } \\
\text { on a 1:1 ratio.." }\end{array}$ \\
\hline Allocation concealment? & No & $\begin{array}{l}\text { "Patients in the FBG group were told about postoperative } \\
\text { donor site complications" }\end{array}$ \\
\hline $\begin{array}{l}\text { Blinding? } \\
\text { All outcomes - patients? }\end{array}$ & No & $\begin{array}{l}\text { "patients in the FBG group were told about donor site com- } \\
\text { plications" }\end{array}$ \\
\hline
\end{tabular}


Celik 2007 (Continued)

\begin{tabular}{l|l|l}
\hline $\begin{array}{l}\text { Blinding? } \\
\text { All outcomes - outcome assessors? }\end{array}$ & Unclear & Not mentioned \\
\hline $\begin{array}{l}\text { Blinding? } \\
\text { All outcomes - care provider? }\end{array}$ & No possible in surgical procedures & No mention at all \\
\hline $\begin{array}{l}\text { Incomplete outcome data addressed? } \\
\text { All outcomes - drop-outs? }\end{array}$ & Unclear & \\
\hline $\begin{array}{l}\text { Incomplete outcome data addressed? } \\
\text { All outcomes - ITT analysis? }\end{array}$ & Yes & \\
\hline Free of selective reporting? & Yes & \\
\hline Similarity of baseline characteristics? & Yes & \\
\hline Co-interventions avoided or similar? & Yes \\
\hline Compliance acceptable? & Yes \\
\hline Timing outcome assessments similar? & Yes \\
\hline
\end{tabular}

\section{Dai 2008}

\begin{tabular}{ll}
\hline Methods & RCT, Method not described \\
\hline Participants & $\begin{array}{l}\text { Progressive upper extremity radicular symptoms and/or myelopathy } \\
\text { Soft disc herniation or spondylosis } \\
\text { Exclusion: } 2 \text { levels, ossification posterior longitudinal ligament, prior cervical surgery, } \\
\text { significant co-morbidities }\end{array}$ \\
\hline Interventions & $\begin{array}{l}\text { 1: Carbon fibre OR PEEK cage filled with granulated beta-TCP and plate } \\
\text { 2: Carbon fibre OR PEEK cage filled with granulated beta-TCP }\end{array}$ \\
\hline Outcomes & $\begin{array}{l}\text { Radiological: Fusion, Cobb angle } \\
\text { Clinical: VAS arm, VAS neck } \\
\text { Functional: JOA }\end{array}$ \\
\hline Notes & $\begin{array}{l}\text { Diagnosis DD: Conventional x-ray, MRI } \\
\text { Cause of pain: Radiculopathy, myelopathy, disc herniation/spondylosis } \\
\text { Levels: 25/62 (40\%) one level; 37 (60\%) two level }\end{array}$ \\
\hline Risk of bias & \begin{tabular}{l} 
Unclear \\
\hline Adequate sequence generation?
\end{tabular} \\
\hline
\end{tabular}


Dai 2008 (Continued)

\begin{tabular}{|c|c|c|}
\hline Allocation concealment? & Unclear & Not described \\
\hline $\begin{array}{l}\text { Blinding? } \\
\text { All outcomes - patients? }\end{array}$ & Unclear & Not described \\
\hline $\begin{array}{l}\text { Blinding? } \\
\text { All outcomes - outcome assessors? }\end{array}$ & No & \\
\hline $\begin{array}{l}\text { Blinding? } \\
\text { All outcomes - care provider? }\end{array}$ & No & Not possible in surgical procedures \\
\hline $\begin{array}{l}\text { Incomplete outcome data addressed? } \\
\text { All outcomes - drop-outs? }\end{array}$ & Yes & \\
\hline $\begin{array}{l}\text { Incomplete outcome data addressed? } \\
\text { All outcomes - ITT analysis? }\end{array}$ & Yes & \\
\hline Free of selective reporting? & Yes & \\
\hline Similarity of baseline characteristics? & Yes & \\
\hline Co-interventions avoided or similar? & Yes & \\
\hline Compliance acceptable? & Yes & \\
\hline Timing outcome assessments similar? & Yes & \\
\hline
\end{tabular}

Dowd 1999

\begin{tabular}{ll}
\hline Methods & RCT, closed envelopes \\
\hline Participants & 1 or 2 level spondylosis, radiculopathy, radiculo-myelopathy \\
\hline Interventions & $\begin{array}{l}\text { 1: Discectomy with Smith and Robinson } \\
\text { 2: Discectomy with Smith and Robinson and fusion with Cloward using iliac crest } \\
\text { autograft }\end{array}$ \\
\hline Outcomes & $\begin{array}{l}\text { Radiological: Lateral cervical spine X-ray } \\
\text { Clinical: Complications, pain } \\
\text { Functional: Return to work }\end{array}$ \\
\hline Notes & $\begin{array}{l}\text { No exclusion criteria; } \\
\text { Diagnosis DD; } \\
\text { Cause of pain: radiculopathy, radiculo-myelopathy } \\
\text { Levels: } 46 / 84 \text { (55\%) one level; 38 (45\%) two level }\end{array}$ \\
\hline
\end{tabular}

Risk of bias 
Dowd 1999 (Continued)

\begin{tabular}{|c|c|c|}
\hline Item & Authors' judgement & Description \\
\hline Adequate sequence generation? & Yes & The randomisation technique is valid \\
\hline Allocation concealment? & Yes & \\
\hline $\begin{array}{l}\text { Blinding? } \\
\text { All outcomes - patients? }\end{array}$ & No & \\
\hline $\begin{array}{l}\text { Blinding? } \\
\text { All outcomes - outcome assessors? }\end{array}$ & No & \\
\hline $\begin{array}{l}\text { Blinding? } \\
\text { All outcomes - care provider? }\end{array}$ & No & Not possible in surgical procedures \\
\hline $\begin{array}{l}\text { Incomplete outcome data addressed? } \\
\text { All outcomes - drop-outs? }\end{array}$ & No & $\begin{array}{l}\text { The percentage lost to follow-up at } 4.5 \text { years was larger than } \\
20 \%\end{array}$ \\
\hline $\begin{array}{l}\text { Incomplete outcome data addressed? } \\
\text { All outcomes - ITT analysis? }\end{array}$ & Unclear & Unclear from text \\
\hline Free of selective reporting? & Unclear & Outcome parameters not mentioned \\
\hline Similarity of baseline characteristics? & Yes & \\
\hline Co-interventions avoided or similar? & Yes & \\
\hline Compliance acceptable? & Yes & \\
\hline Timing outcome assessments similar? & Yes & \\
\hline
\end{tabular}

\section{Feiz-Erfan 2007}

\begin{tabular}{ll} 
Methods & RCT, Method unclear \\
\hline Participants & $\begin{array}{l}\text { Inclusion: Neurological deficit appropriate for level; MRI or CT confirmed; Failure non- } \\
\text { surgical treatment; Change activity, Use of cervical collar and steroids }\end{array}$ \\
\hline Interventions & $\begin{array}{l}\text { 1: Anterior Plate (Slimloc, Depuy) with VG2 allograft with platelet } \\
\text { 2: Anterior Plate (Slimloc, Depuy) with VG2 allograft without platelet }\end{array}$ \\
\hline Outcomes & $\begin{array}{l}\text { Radiological: Fusion on Ap/lateral and Flexion/extension X rays } \\
\text { Clinical: VAS } \\
\text { Functional: Sf36, NDI, Prolo }\end{array}$ \\
\hline Notes & $\begin{array}{l}\text { Diagnosis DD: MRI, CT } \\
\text { Cause of pain: DDD or Herniated disc }\end{array}$ \\
\hline
\end{tabular}


Feiz-Erfan 2007 (Continued)

Levels: $19 / 50$ (38\%) one level; $31(62 \%)$ two level

\section{Risk of bias}

\begin{tabular}{|c|c|c|}
\hline Item & Authors' judgement & Description \\
\hline Adequate sequence generation? & Unclear & "Randomised" "on a blinded 1:1 basis" \\
\hline Allocation concealment? & Unclear & not mentioned \\
\hline $\begin{array}{l}\text { Blinding? } \\
\text { All outcomes - patients? }\end{array}$ & Yes & \\
\hline $\begin{array}{l}\text { Blinding? } \\
\text { All outcomes - outcome assessors? }\end{array}$ & Unclear & Not mentioned \\
\hline $\begin{array}{l}\text { Blinding? } \\
\text { All outcomes - care provider? }\end{array}$ & No & Not possible in surgical procedures \\
\hline $\begin{array}{l}\text { Incomplete outcome data addressed? } \\
\text { All outcomes - drop-outs? }\end{array}$ & No & \\
\hline $\begin{array}{l}\text { Incomplete outcome data addressed? } \\
\text { All outcomes - ITT analysis? }\end{array}$ & Yes & \\
\hline Free of selective reporting? & No & \\
\hline Similarity of baseline characteristics? & Unclear & Information on platelet groups is missing \\
\hline Co-interventions avoided or similar? & Yes & \\
\hline Compliance acceptable? & Yes & \\
\hline Timing outcome assessments similar? & Yes & \\
\hline
\end{tabular}

Fernandez-Fairen 2008

\begin{tabular}{ll}
\hline Methods & RCT, Computer generated random list \\
\hline Participants & $\begin{array}{l}\text { Inclusion: Neck pain, brachialgia, nerve root comparison/ herniated disc or spondylosis, } 1 \\
\text { level c3-c7, MRI confirmed, Conservative treatment, No surgical previous intervention, } \\
\text { age 18-65 } \\
\text { Exclusion: Other cervical spine conditions, Myeolpathy, Ostopenia, osteoporosis, osteo- } \\
\text { malacia, metabolic bone diseases, Local infection, tumour, Smokers, drug abuse, alcohol, } \\
\text { Work related conditions }\end{array}$ \\
\hline Interventions & $\begin{array}{l}\text { 1: Anterior plate (alpha plate Stryker), IIiac crest Autograft } \\
\text { 2: Tantalum cervical fusion cage (Zimmer) }\end{array}$ \\
\hline
\end{tabular}


Fernandez-Fairen 2008 (Continued)

\begin{tabular}{|c|c|c|}
\hline Outcomes & \multicolumn{2}{|c|}{$\begin{array}{l}\text { Radiological: fusion on Ap/lateral and Flexion/extension X-rays } \\
\text { Clinical: VAS, Duration of surgery, Blood loss, Hospital stay } \\
\text { Functional: Odom, NDI, Zung }\end{array}$} \\
\hline Notes & \multicolumn{2}{|c|}{$\begin{array}{l}\text { Diagnosis DD: MRI } \\
\text { Cause of pain: nerve root comparison/ herniated disc or spondylosis } \\
\text { Levels: } 61(100 \%) \text { one level }\end{array}$} \\
\hline \multicolumn{3}{|l|}{ Risk of bias } \\
\hline Item & Authors' judgement & Description \\
\hline Adequate sequence generation? & Yes & Computer generated random list \\
\hline Allocation concealment? & Unclear & Not described \\
\hline $\begin{array}{l}\text { Blinding? } \\
\text { All outcomes - patients? }\end{array}$ & No & \\
\hline $\begin{array}{l}\text { Blinding? } \\
\text { All outcomes - outcome assessors? }\end{array}$ & No & \\
\hline $\begin{array}{l}\text { Blinding? } \\
\text { All outcomes - care provider? }\end{array}$ & No & Not possible in surgical procedures \\
\hline $\begin{array}{l}\text { Incomplete outcome data addressed? } \\
\text { All outcomes - drop-outs? }\end{array}$ & Unclear & $\begin{array}{l}\text { No mention of drop-outs and no description } \\
\text { of } \mathrm{N} \text { for outcome parameters }\end{array}$ \\
\hline $\begin{array}{l}\text { Incomplete outcome data addressed? } \\
\text { All outcomes - ITT analysis? }\end{array}$ & Yes & \\
\hline Free of selective reporting? & Yes & \\
\hline Similarity of baseline characteristics? & Yes & \\
\hline Co-interventions avoided or similar? & Yes & \\
\hline Compliance acceptable? & Yes & \\
\hline Timing outcome assessments similar? & Yes & \\
\hline
\end{tabular}


Hacker 2000

\begin{tabular}{ll}
\hline Methods & RCT, method unclear \\
\hline Participants & $\begin{array}{l}\text { Radiculopathy due to soft disc herniation or osteophytes, } 1 \text { or } 2 \text { levels, C3-C7 } \\
\text { Exclusion: myelopathy, previous surgery at cervical levels }\end{array}$ \\
\hline Interventions & $\begin{array}{l}\text { 1: Discectomy and fusion with iliac crest autograft } \\
\text { 2: Discectomy and fusion with cage with Hydroxyapatite coating } \\
\text { 3: Discectomy and fusion with cage without Hydroxyapatite coating }\end{array}$ \\
\hline Outcomes & $\begin{array}{l}\text { Radiological: Flexion-extension radiographs } \\
\text { Clinical: VAS pain } \\
\text { Functional: SF-36, Work, Daily function }\end{array}$ \\
\hline Notes & $\begin{array}{l}\text { Diagnosis DD: imaging } \\
\text { Cause of pain: Radiculopathy } \\
\text { Levels: } 54 / 64 \text { (84\%) one level; } 10 \text { (16\%) two level }\end{array}$ \\
\hline
\end{tabular}

\section{Risk of bias}

\begin{tabular}{|c|c|c|}
\hline Item & Authors' judgement & Description \\
\hline Adequate sequence generation? & Unclear & Randomisation procedure is not clear \\
\hline Allocation concealment? & Unclear & B - Unclear \\
\hline $\begin{array}{l}\text { Blinding? } \\
\text { All outcomes - patients? }\end{array}$ & No & \\
\hline $\begin{array}{l}\text { Blinding? } \\
\text { All outcomes - outcome assessors? }\end{array}$ & No & \\
\hline $\begin{array}{l}\text { Blinding? } \\
\text { All outcomes - care provider? }\end{array}$ & No & Not possible in surgical procedures \\
\hline $\begin{array}{l}\text { Incomplete outcome data addressed? } \\
\text { All outcomes - drop-outs? }\end{array}$ & Yes & \\
\hline $\begin{array}{l}\text { Incomplete outcome data addressed? } \\
\text { All outcomes - ITT analysis? }\end{array}$ & Yes & \\
\hline Free of selective reporting? & Unclear & No description of planned outcomes \\
\hline Similarity of baseline characteristics? & Yes & \\
\hline Co-interventions avoided or similar? & Yes & \\
\hline Compliance acceptable? & Yes & \\
\hline
\end{tabular}


Hacker 2000 (Continued)

Timing outcome assessments similar? Yes

\section{Hauerberg 2008}

\begin{tabular}{ll}
\hline Methods & RCT, Computer generated list, Opaque envelopes \\
\hline Participants & $\begin{array}{l}\text { Inclusion: Anterior approach, Cervical root compression, 1 level c4-t1, root compression } \\
\text { at max 2 levels, symptoms }>6 \text { weeks, age 18-70 years } \\
\text { Exclusion: Spinal cord compression, History of spine surgery, Neurological disease / } \\
\text { condition }\end{array}$ \\
\hline Interventions & $\begin{array}{l}\text { 1: Ray fusion cage } \\
\text { 2: Discectomy alone }\end{array}$ \\
\hline Outcomes & $\begin{array}{l}\text { Radiological: Fusion } \\
\text { Clinical: Pain } \\
\text { Functional: Recovery, employment status }\end{array}$ \\
\hline Notes & $\begin{array}{l}\text { Diagnosis DD: radiological } \\
\text { Cause of pain: cervical root compression } \\
\text { Levels: } 86 \text { (100\%) one level }\end{array}$ \\
\hline
\end{tabular}

\section{Risk of bias}

\begin{tabular}{l|ll}
\hline Item & Authors' judgement & Description \\
\hline Adequate sequence generation? & Yes & Computer generated list \\
\hline Allocation concealment? & Yes & Opaque envelopes \\
\hline $\begin{array}{l}\text { Blinding? } \\
\text { All outcomes - patients? }\end{array}$ & No & \\
\hline $\begin{array}{l}\text { Blinding? } \\
\text { All outcomes - outcome assessors? }\end{array}$ & No & Not possible in surgical procedures \\
\hline $\begin{array}{l}\text { Blinding? } \\
\text { All outcomes - care provider? }\end{array}$ & No & \\
\hline $\begin{array}{l}\text { Incomplete outcome data addressed? } \\
\text { All outcomes - drop-outs? }\end{array}$ & Yes & \\
\hline $\begin{array}{l}\text { Incomplete outcome data addressed? } \\
\text { All outcomes - ITT analysis? }\end{array}$ & Yes & \\
\hline \begin{tabular}{l} 
Free of selective reporting? \\
\hline
\end{tabular} & Yes & \\
\hline
\end{tabular}




\section{Hauerberg 2008 (Continued)}

\begin{tabular}{ll}
\hline Similarity of baseline characteristics? & Yes \\
\hline Co-interventions avoided or similar? & No \\
\hline Compliance acceptable? & Yes \\
\hline Timing outcome assessments similar? & Yes \\
\hline
\end{tabular}

\section{Lind 2007}

\begin{tabular}{ll}
\hline Methods & RCT, method unclear, Sealed envelopes \\
\hline Participants & $\begin{array}{l}\text { Inclusion: Radiculopathy, MRI verified disc herniation/spondylosis, 1 level, c4-c7 } \\
\text { Exclusion: Myelopathy }\end{array}$ \\
\hline Interventions & $\begin{array}{l}\text { 1:Threaded titanium (Centrepulse) } \\
\text { 2: Iliac crest autograft }\end{array}$ \\
\hline Outcomes & $\begin{array}{l}\text { Radiological: Migration (RSA) } \\
\text { Clinical: VAS } \\
\text { Functional: ODOM }\end{array}$ \\
\hline Notes & $\begin{array}{l}\text { Diagnosis DD: MRI } \\
\text { Cause of pain: Radiculopathy, disc herniation/spondylosis } \\
\text { levels: } 24(100 \%) \text { one level }\end{array}$ \\
\hline
\end{tabular}

\section{Risk of bias}

\begin{tabular}{|c|c|c|}
\hline Item & Authors' judgement & Description \\
\hline Adequate sequence generation? & Unclear & Not mentioned \\
\hline Allocation concealment? & Yes & Sealed envelopes \\
\hline $\begin{array}{l}\text { Blinding? } \\
\text { All outcomes - patients? }\end{array}$ & No & \\
\hline $\begin{array}{l}\text { Blinding? } \\
\text { All outcomes - outcome assessors? }\end{array}$ & Yes & \\
\hline $\begin{array}{l}\text { Blinding? } \\
\text { All outcomes - care provider? }\end{array}$ & No & Not possible in surgical procedures \\
\hline $\begin{array}{l}\text { Incomplete outcome data addressed? } \\
\text { All outcomes - drop-outs? }\end{array}$ & Yes & \\
\hline
\end{tabular}


Lind 2007 (Continued)

\begin{tabular}{l|l}
\hline $\begin{array}{l}\text { Incomplete outcome data addressed? } \\
\text { All outcomes - ITT analysis? }\end{array}$ & Yes \\
\hline Free of selective reporting? & No \\
\hline Similarity of baseline characteristics? & No \\
\hline Co-interventions avoided or similar? & Yes \\
\hline Compliance acceptable? & Yes \\
\hline Timing outcome assessments similar? & Yes \\
\hline
\end{tabular}

Lofgren 2000

\begin{tabular}{ll}
\hline Methods & RCT, sealed envelopes \\
\hline Participants & Cervical disc protrusion, stenosis or both \\
\hline Interventions & $\begin{array}{l}\text { Discectomy and fusion with Cloward with: } \\
\text { 1: iliac crest autograft } \\
\text { 2: Femoral head allograft } \\
\text { 3: Bovine Xenograft }\end{array}$ \\
\hline Outcomes & $\begin{array}{l}\text { Radiological: RSA, conventional for bone bridging, flexion extension views } \\
\text { Clinical: VAS pain } \\
\text { Functional: muscle force, sensory function. Observers assessment }\end{array}$ \\
\hline Notes & $\begin{array}{l}\text { No exclusion criteria; } \\
\text { Diagnosis DD ? } \\
\text { Cause of pain: spondylosis, disc herniation } \\
\text { Levels: 43 (100\%) one level }\end{array}$ \\
\hline
\end{tabular}

\section{Risk of bias}

\begin{tabular}{lll}
\hline Item & Authors' judgement & Description \\
\hline Adequate sequence generation? & Yes & good description of the randomisation \\
\hline Allocation concealment? & Yes & \\
\hline $\begin{array}{l}\text { Blinding? } \\
\text { All outcomes - patients? }\end{array}$ & No & \\
\hline $\begin{array}{l}\text { Blinding? } \\
\text { All outcomes - outcome assessors? }\end{array}$ & No & \\
\hline
\end{tabular}


Lofgren 2000 (Continued)

\begin{tabular}{l|l|l}
\hline $\begin{array}{l}\text { Blinding? } \\
\text { All outcomes - care provider? }\end{array}$ & No & Not possible in surgical procedures \\
\hline $\begin{array}{l}\text { Incomplete outcome data addressed? } \\
\text { All outcomes - drop-outs? }\end{array}$ & No high lost to follow-up for the RSA measurements \\
\hline $\begin{array}{l}\text { Incomplete outcome data addressed? } \\
\text { All outcomes - ITT analysis? }\end{array}$ & Yes & Unclear from text \\
\hline Free of selective reporting? & Yes & \\
\hline Similarity of baseline characteristics? & Unclear & \\
\hline Co-interventions avoided or similar? & Yes & \\
\hline Compliance acceptable? & Yes & Yes \\
\hline Timing outcome assessments similar?
\end{tabular}

\section{Lofgren 2010}

\begin{tabular}{ll}
\hline Methods & RCT, Method unclear \\
\hline Participants & $\begin{array}{l}\text { Inclusion: Radiculopathy, Degenerative disc disease (HNP/spondylosis), Compatible } \\
\text { MRI/ clinic } \\
\text { Exclusion: Previous cervical spine surgery, Postraumatic, Inflammatory systemic disease, } \\
\text { Neurological disease, Drug/alcohol abuse }\end{array}$ \\
\hline Interventions & $\begin{array}{l}\text { 1: Iliac crest autograft } \\
\text { 2: Trabecular metal cage }\end{array}$ \\
\hline Outcomes & $\begin{array}{l}\text { Radiological: - } \\
\text { Clinical: Operation time, Blood loss, VAS neck, VAS arm } \\
\text { Functional: NDI, Patient global assessment }\end{array}$ \\
\hline Notes & $\begin{array}{l}\text { Diagnosis DD: MRI } \\
\text { Cause of pain: Radiculopathy } \\
\text { Levels: } 80 \text { (100\%) one level }\end{array}$ \\
\hline
\end{tabular}

\section{Risk of bias}

\begin{tabular}{lll}
\hline Item & Authors' judgement & Description \\
\hline Adequate sequence generation? & Unclear & Procedure not described \\
\hline Allocation concealment? & Yes & closed envelopes
\end{tabular}


Lofgren 2010 (Continued)

\begin{tabular}{l|l|l}
\hline $\begin{array}{l}\text { Blinding? } \\
\text { All outcomes - patients? }\end{array}$ & No & Not possible (iliac crest scar) \\
\hline $\begin{array}{l}\text { Blinding? } \\
\text { All outcomes - outcome assessors? }\end{array}$ & No & observer unbiased, blinding not mentioned \\
\hline $\begin{array}{l}\text { Blinding? } \\
\text { All outcomes - care provider? }\end{array}$ & Unclear & no lost to follow-up \\
\hline $\begin{array}{l}\text { Incomplete outcome data addressed? } \\
\text { All outcomes - drop-outs? }\end{array}$ & Yes & no cross over \\
\hline $\begin{array}{l}\text { Incomplete outcome data addressed? } \\
\text { All outcomes - ITT analysis? }\end{array}$ & Yes & All outcomes accounted for \\
\hline $\begin{array}{l}\text { Free of selective reporting? } \\
\text { Similarity of baseline characteristics? }\end{array}$ & Yes & As far as reported similar \\
\hline Co-interventions avoided or similar? & Yes & not extensively described \\
\hline \begin{tabular}{l} 
Compliance acceptable? \\
\hline Timing outcome assessments similar?
\end{tabular} & Yes & implant present \\
\hline
\end{tabular}

\section{Madawi 1996}

\begin{tabular}{ll}
\hline Methods & RCT, method unclear \\
\hline Participants & $\begin{array}{l}\text { Fresh, } 1 \text { or } 2 \text { level symptomatic cervical disc disease (radiculopathy, myelopathy, radiculo- } \\
\text { myelopathy) } \\
\text { Exclusion: Multilevel, OSS, PLL, malalignment, sepsis, re-operations, instrumented sta- } \\
\text { bilisation }\end{array}$ \\
\hline Interventions & $\begin{array}{l}\text { Discectomy with Smith and Robinson or Cloward with } \\
\text { 1: Biocompatible osteo-conductive polymer } \\
\text { 2: Iliac crest autograft }\end{array}$ \\
\hline Outcomes & $\begin{array}{l}\text { Radiological: Radiograph/CT/MRI } \\
\text { Clinical: Odom's criteria, VAS }\end{array}$ \\
\hline Notes & $\begin{array}{l}\text { Diagnosis DD: Clinical and radiological examination, no imaging for diagnosis } \\
\text { Cause of pain: Radiculopathy, myelopathy, Radiculomyelopathy } \\
\text { Levels: 82/115 (71\%) one level; 33 (29\%) two level }\end{array}$ \\
\hline
\end{tabular}

Risk of bias 
Madawi 1996 (Continued)

\begin{tabular}{|c|c|c|}
\hline Item & Authors' judgement & Description \\
\hline Adequate sequence generation? & Unclear & The randomisation technique was not described \\
\hline Allocation concealment? & Unclear & Unclear \\
\hline $\begin{array}{l}\text { Blinding? } \\
\text { All outcomes - patients? }\end{array}$ & No & \\
\hline $\begin{array}{l}\text { Blinding? } \\
\text { All outcomes - outcome assessors? }\end{array}$ & No & \\
\hline $\begin{array}{l}\text { Blinding? } \\
\text { All outcomes - care provider? }\end{array}$ & No & Not possible in surgical procedures \\
\hline $\begin{array}{l}\text { Incomplete outcome data addressed? } \\
\text { All outcomes - drop-outs? }\end{array}$ & Unclear & Unclear from text \\
\hline $\begin{array}{l}\text { Incomplete outcome data addressed? } \\
\text { All outcomes - ITT analysis? }\end{array}$ & Yes & \\
\hline Free of selective reporting? & Yes & \\
\hline Similarity of baseline characteristics? & Yes & \\
\hline Co-interventions avoided or similar? & Yes & \\
\hline Compliance acceptable? & Yes & \\
\hline Timing outcome assessments similar? & Unclear & timing of the follow-up is questionable \\
\hline
\end{tabular}

\section{Martins 1976}

\begin{tabular}{ll} 
Methods & RCT, method unclear \\
\hline Participants & $\begin{array}{l}\text { Refractory signs and symptoms of cervical disc disease and radiculopathy } \\
-1 \text { or } 2 \text { levels } \\
- \text { Abnormalities of cervical spine radiographs correlated with the clinical picture }\end{array}$ \\
\hline Interventions & $\begin{array}{l}1: \text { Discectomy } \\
\text { 2: Discectomy and fusion according to the Cloward procedure }\end{array}$ \\
\hline Outcomes & $\begin{array}{l}\text { Radiological: Flexion-extension X-rays } \\
\text { Clinical: Custom criteria }\end{array}$ \\
\hline Notes & $\begin{array}{l}\text { Diagnosis DD: Radiograph/Myelogram } \\
\text { Cause of pain: Cervical disc disease and radiculopathy }\end{array}$ \\
\hline $\begin{array}{l}\text { Single or double-level anterior interbody fusion techniques for cervical degenerative disc disease (Review) } \\
\text { Copyright } \odot \text { 20II The Cochrane Collaboration. Published by John Wiley \& Sons, Ltd. }\end{array}$
\end{tabular}


Martins 1976 (Continued)

Levels: 16/51 (31\%) one level; 35 (69\%) two level

\section{Risk of bias}

\begin{tabular}{|c|c|c|}
\hline Item & Authors' judgement & Description \\
\hline Adequate sequence generation? & Unclear & The randomisation technique was not described (lottery style) \\
\hline Allocation concealment? & Unclear & B - Unclear \\
\hline $\begin{array}{l}\text { Blinding? } \\
\text { All outcomes - patients? }\end{array}$ & No & \\
\hline $\begin{array}{l}\text { Blinding? } \\
\text { All outcomes - outcome assessors? }\end{array}$ & No & \\
\hline $\begin{array}{l}\text { Blinding? } \\
\text { All outcomes - care provider? }\end{array}$ & No & Not possible in surgical procedures \\
\hline $\begin{array}{l}\text { Incomplete outcome data addressed? } \\
\text { All outcomes - drop-outs? }\end{array}$ & Unclear & Unclear from text \\
\hline $\begin{array}{l}\text { Incomplete outcome data addressed? } \\
\text { All outcomes - ITT analysis? }\end{array}$ & Yes & \\
\hline Free of selective reporting? & Unclear & Outcome parameters not clearly described prospectively \\
\hline Similarity of baseline characteristics? & Unclear & Unclear from text \\
\hline Co-interventions avoided or similar? & Yes & \\
\hline Compliance acceptable? & Yes & \\
\hline Timing outcome assessments similar? & Yes & \\
\hline
\end{tabular}

McConnel 2003

\begin{tabular}{ll}
\hline Methods & RCT, sealed envelopes \\
\hline Participants & $\begin{array}{l}\text { Radiculopathy, myelopathy, discogenic pain, spondylosis, segmental instability, forami- } \\
\text { nal stenosis }\end{array}$ \\
\hline Interventions & $\begin{array}{l}\text { Discectomy with Smith and Robinson and fusion with anterior plate and with: } \\
\text { 1: Iliac crest autograft } \\
\text { 2: ProOsteon 200 Block }\end{array}$
\end{tabular}


McConnel 2003 (Continued)

\begin{tabular}{ll} 
Outcomes & $\begin{array}{l}\text { Radiological: fragmentation, graft height, angular alignment, plate complications } \\
\text { Clinical: - ? } \\
\text { Functional: SF-36, Oswestry disability index, }\end{array}$ \\
\hline Notes & $\begin{array}{l}\text { Diagnosis DD } \\
\text { Cause of pain: Radiculopathy, myelopathy, discogenic pain, spondylosis, segmental in- } \\
\text { stability, foraminal stenosis } \\
\text { Levels: } 18 / 29(62 \%) \text { one level; } 9 / 29(31 \%) \text { two level; } 2 / 29(7 \%) \text { Three level }\end{array}$ \\
\hline
\end{tabular}

Risk of bias

\begin{tabular}{|c|c|c|}
\hline Item & Authors' judgement & Description \\
\hline Adequate sequence generation? & Yes & The randomisation technique used sealed envelopes. \\
\hline Allocation concealment? & Yes & \\
\hline $\begin{array}{l}\text { Blinding? } \\
\text { All outcomes - patients? }\end{array}$ & No & \\
\hline $\begin{array}{l}\text { Blinding? } \\
\text { All outcomes - outcome assessors? }\end{array}$ & No & \\
\hline $\begin{array}{l}\text { Blinding? } \\
\text { All outcomes - care provider? }\end{array}$ & No & Not possible in surgical procedures \\
\hline $\begin{array}{l}\text { Incomplete outcome data addressed? } \\
\text { All outcomes - drop-outs? }\end{array}$ & Unclear & drop-out percentage is moderate \\
\hline $\begin{array}{l}\text { Incomplete outcome data addressed? } \\
\text { All outcomes - ITT analysis? }\end{array}$ & Yes & \\
\hline Free of selective reporting? & Yes & \\
\hline Similarity of baseline characteristics? & Yes & \\
\hline Co-interventions avoided or similar? & Yes & \\
\hline Compliance acceptable? & Yes & \\
\hline Timing outcome assessments similar? & Yes & \\
\hline
\end{tabular}


McGuire 1994

\begin{tabular}{|c|c|c|}
\hline Methods & \multicolumn{2}{|l|}{ RCT, method unclear } \\
\hline Participants & \multicolumn{2}{|c|}{$\begin{array}{l}\text { Radiculopathy with motor and sensory deficits and associated neck pain } \\
\text { Failing to conservative treatment. } \\
\text { Exclusion: Informed consent failure }\end{array}$} \\
\hline Interventions & \multicolumn{2}{|c|}{$\begin{array}{l}\text { 1: Discectomy and fusion (Williams) with vertebral body autograft } \\
\text { 2: Discectomy and fusion }(S+R) \text { with Iliac crest autograft }\end{array}$} \\
\hline Outcomes & \multicolumn{2}{|c|}{$\begin{array}{l}\text { Radiological: Disc height and sagittal rotation } \\
\text { Clinical: Custom criteria }\end{array}$} \\
\hline Notes & \multicolumn{2}{|c|}{$\begin{array}{l}\text { Diagnosis DD: Radiographic/MRI/CT } \\
\text { Cause of pain: Radiculopathy } \\
\text { Levels: } 42 / 46(91 \%) \text { one level; } 4(9 \%) \text { two level }\end{array}$} \\
\hline \multicolumn{3}{|l|}{ Risk of bias } \\
\hline Item & Authors' judgement & Description \\
\hline Adequate sequence generation? & Unclear & $\begin{array}{l}\text { The randomisation technique was not described which makes } \\
\text { the study suspicious because of the unequal group sizes }\end{array}$ \\
\hline Allocation concealment? & Unclear & Unclear \\
\hline $\begin{array}{l}\text { Blinding? } \\
\text { All outcomes - patients? }\end{array}$ & No & \\
\hline $\begin{array}{l}\text { Blinding? } \\
\text { All outcomes - outcome assessors? }\end{array}$ & No & \\
\hline $\begin{array}{l}\text { Blinding? } \\
\text { All outcomes - care provider? }\end{array}$ & No & Not possible in surgical procedures \\
\hline $\begin{array}{l}\text { Incomplete outcome data addressed? } \\
\text { All outcomes - drop-outs? }\end{array}$ & Unclear & Unclear from text \\
\hline $\begin{array}{l}\text { Incomplete outcome data addressed? } \\
\text { All outcomes - ITT analysis? }\end{array}$ & Unclear & Unclear from text \\
\hline Free of selective reporting? & Unclear & Incomplete description of outcome parameters \\
\hline Similarity of baseline characteristics? & Unclear & Unclear from text \\
\hline Co-interventions avoided or similar? & Yes & \\
\hline Compliance acceptable? & Unclear & Unclear from text \\
\hline
\end{tabular}


McGuire 1994 (Continued)

Timing outcome assessments similar? Yes

Nabhan 2007

\begin{tabular}{ll}
\hline Methods & RCT, Method unclear, Sealed envelopes \\
\hline Participants & $\begin{array}{l}\text { Inclusion: Degenerative disc disease, Radiculopath or myelopathy, Unresponsive to Con- } \\
\text { servative therapy } \\
\text { Exclusion: no criteria }\end{array}$ \\
\hline Interventions & $\begin{array}{l}\text { 1: Solis Peek cage (Stryker) } \\
\text { 2: Solis Peek cage (Stryker) with Caspar plate }\end{array}$ \\
\hline Outcomes & $\begin{array}{l}\text { Radiological: Migration (RSA) } \\
\text { Clinical: VAS } \\
\text { Functional: none }\end{array}$ \\
\hline Notes & $\begin{array}{l}\text { Diagnosis DD: confirmatory imaging studies } \\
\text { Cause of pain: Degenerative disc disease, Radiculopath or myelopathy } \\
\text { Levels: } 37 \text { (100\%) one level }\end{array}$ \\
\hline
\end{tabular}

\section{Risk of bias}

\begin{tabular}{|c|c|c|}
\hline Item & Authors' judgement & Description \\
\hline Adequate sequence generation? & Unclear & Not reported \\
\hline Allocation concealment? & Yes & Sealed envelopes \\
\hline $\begin{array}{l}\text { Blinding? } \\
\text { All outcomes - patients? }\end{array}$ & No & $\begin{array}{l}\text { Not mentioned, result can be easily identified } \\
\text { on } \mathrm{Rx}\end{array}$ \\
\hline $\begin{array}{l}\text { Blinding? } \\
\text { All outcomes - outcome assessors? }\end{array}$ & Unclear & Not described \\
\hline $\begin{array}{l}\text { Blinding? } \\
\text { All outcomes - care provider? }\end{array}$ & No & Not possible in surgical procedures \\
\hline $\begin{array}{l}\text { Incomplete outcome data addressed? } \\
\text { All outcomes - drop-outs? }\end{array}$ & Yes & \\
\hline $\begin{array}{l}\text { Incomplete outcome data addressed? } \\
\text { All outcomes - ITT analysis? }\end{array}$ & Unclear & Not mentioned \\
\hline Free of selective reporting? & Yes & All parameters accounted for \\
\hline Similarity of baseline characteristics? & Unclear & Not reported \\
\hline
\end{tabular}

Copyright @ 201 I The Cochrane Collaboration. Published by John Wiley \& Sons, Ltd. 
Nabhan 2007 (Continued)

\begin{tabular}{ll}
\hline Co-interventions avoided or similar? & Yes \\
\hline Compliance acceptable? & Yes \\
\hline Timing outcome assessments similar? & Yes \\
\hline
\end{tabular}

Nunley 2009

\begin{tabular}{ll}
\hline Methods & RCT, Method Computer generated block randomised list \\
\hline Participants & $\begin{array}{l}\text { Inclusion: age 18-75, symptomatic DDD, 1-3 levels, c3-c7, radiological evidence of } \\
\text { compressed cervical nerve/cord by bone/hernia, radiculopathy, fusion candidates } \\
\text { Exclusion: Acute trauma, Severe myelopathy, Cervical instability, Severe facet disease, } \\
\text { Posterior augmentation, Revision, Previous surgery at level }\end{array}$ \\
\hline Interventions & $\begin{array}{l}\text { 1: Ctek (Biomet spine) static plate with Allograft } \\
\text { 2: Ctek (Biomet spine) dynamic plate with Allograft }\end{array}$ \\
\hline Outcomes & $\begin{array}{l}\text { Radiological: Fusion at Flexion/Extension } \\
\text { Clinical: VAS } \\
\text { Functional: NDI }\end{array}$ \\
\hline Notes & $\begin{array}{l}\text { Diagnosis DD: radiological } \\
\text { Cause of pain: compressed cervical nerve/cord by bone/hernia, radiculopathy } \\
\text { Levels: } 28 / 66 \text { (42\%) one level; 38/66 (58\%) two or three level }\end{array}$ \\
\hline
\end{tabular}

\section{Risk of bias}

\begin{tabular}{l|l|l}
\hline Item & Authors' judgement & Description \\
\hline Adequate sequence generation? & Yes & Computer generated block randomised list \\
\hline Allocation concealment? & Unclear & Not described \\
\hline $\begin{array}{l}\text { Blinding? } \\
\text { All outcomes - patients? }\end{array}$ & Yes & No \\
\hline $\begin{array}{l}\text { Blinding? } \\
\text { All outcomes - outcome assessors? }\end{array}$ & No & Not possible in surgical procedures \\
\hline $\begin{array}{l}\text { Blinding? } \\
\text { All outcomes - care provider? }\end{array}$ & No & \\
\hline
\end{tabular}

Incomplete outcome data addressed? Yes

All outcomes - drop-outs? 
Nunley 2009 (Continued)

\begin{tabular}{|c|c|c|}
\hline $\begin{array}{l}\text { Incomplete outcome data addressed? } \\
\text { All outcomes - ITT analysis? }\end{array}$ & Yes & \\
\hline Free of selective reporting? & Yes & \\
\hline Similarity of baseline characteristics? & Unclear & Not described per group \\
\hline Co-interventions avoided or similar? & Yes & \\
\hline Compliance acceptable? & Yes & \\
\hline Timing outcome assessments similar? & Unclear & Follow up varies, unclear per group \\
\hline
\end{tabular}

\section{Oktenoglu 2007}

\begin{tabular}{ll}
\hline Methods & RCT, Method: Heads or tails for each patient before the operation \\
\hline Participants & $\begin{array}{l}\text { Inclusion: No previous cervical surgery, Radiculopathy, MRI confirmed, Single level, } 2 \\
\text { weeks conservative treatment } \\
\text { Exclusion: Significant degenerative spinal disorder }\end{array}$ \\
\hline Interventions & $\begin{array}{l}\text { 1: Discectomy alone } \\
\text { 2: Plate (Tnipsan), iliac crest allograft (Tutoplast, Tutogen) }\end{array}$ \\
\hline Outcomes & $\begin{array}{l}\text { Radiological: Disc height, Foramen height } \\
\text { Clinical: VAS } \\
\text { Functional: none }\end{array}$ \\
\hline Notes & $\begin{array}{l}\text { Diagnosis DD: MRI } \\
\text { Cause of pain: Radiculopathy } \\
\text { Levels: } 20 \text { (100\%) one level }\end{array}$ \\
\hline
\end{tabular}

\section{Risk of bias}

\begin{tabular}{lll}
\hline Item & Authors' judgement & Description \\
\hline Adequate sequence generation? & Yes & Heads or tails \\
\hline Allocation concealment? & Yes & \\
\hline $\begin{array}{l}\text { Blinding? } \\
\text { All outcomes - patients? }\end{array}$ & No & \\
\hline $\begin{array}{l}\text { Blinding? } \\
\text { All outcomes - outcome assessors? }\end{array}$ & Yes &
\end{tabular}


Oktenoglu 2007 (Continued)

\begin{tabular}{|c|c|c|}
\hline $\begin{array}{l}\text { Blinding? } \\
\text { All outcomes - care provider? }\end{array}$ & No & Not possible in surgical procedures \\
\hline $\begin{array}{l}\text { Incomplete outcome data addressed? } \\
\text { All outcomes - drop-outs? }\end{array}$ & Yes & \\
\hline $\begin{array}{l}\text { Incomplete outcome data addressed? } \\
\text { All outcomes - ITT analysis? }\end{array}$ & Yes & \\
\hline Free of selective reporting? & Yes & \\
\hline Similarity of baseline characteristics? & Unclear & Not enough information \\
\hline Co-interventions avoided or similar? & Unclear & Not described \\
\hline Compliance acceptable? & Yes & \\
\hline Timing outcome assessments similar? & Unclear & Follow up varies, not given per group \\
\hline
\end{tabular}

Pan 2005

\begin{tabular}{|c|c|c|}
\hline Methods & \multicolumn{2}{|l|}{ RCT, Method unclear } \\
\hline Participants & \multicolumn{2}{|c|}{$\begin{array}{l}\text { Inclusion: Patients who underwent one- and two level anterior cervical discectomy and } \\
\text { fusion } \\
\text { Exclusion: - }\end{array}$} \\
\hline Interventions & \multicolumn{2}{|c|}{$\begin{array}{l}\text { 1: Caspar titanium Plate, Screws Graft } \\
\text { 2: Screws Graft }\end{array}$} \\
\hline Outcomes & \multicolumn{2}{|c|}{$\begin{array}{l}\text { Radiological: Fusion, Disc Height, cervical lordotic alignment } \\
\text { Clinical: JOA } \\
\text { Functional: Improvement }\end{array}$} \\
\hline Notes & \multicolumn{2}{|l|}{$\begin{array}{l}\text { Diagnosis DD: ? } \\
\text { Cause of pain: ? } \\
\text { Levels: ? }\end{array}$} \\
\hline \multicolumn{3}{|l|}{ Risk of bias } \\
\hline Item & Authors' judgement & Description \\
\hline Adequate sequence generation? & Unclear & $\begin{array}{l}\text { They did not discuss the method, just say 'they were ran- } \\
\text { domised' }\end{array}$ \\
\hline Allocation concealment? & No & \\
\hline
\end{tabular}


Pan 2005 (Continued)

\begin{tabular}{|c|c|c|}
\hline $\begin{array}{l}\text { Blinding? } \\
\text { All outcomes - patients? }\end{array}$ & No & not mentioned \\
\hline $\begin{array}{l}\text { Blinding? } \\
\text { All outcomes - outcome assessors? }\end{array}$ & Unclear & not mentioned \\
\hline $\begin{array}{l}\text { Blinding? } \\
\text { All outcomes - care provider? }\end{array}$ & No & Not possible in surgical procedures \\
\hline $\begin{array}{l}\text { Incomplete outcome data addressed? } \\
\text { All outcomes - drop-outs? }\end{array}$ & No & $32 \%$ drop out, not discussed \\
\hline $\begin{array}{l}\text { Incomplete outcome data addressed? } \\
\text { All outcomes - ITT analysis? }\end{array}$ & No & 26 patients were not followed up, but no explanation was given \\
\hline Free of selective reporting? & Yes & $\begin{array}{l}\text { All result of outcomes were clearly reported for each group. } \\
\text { There is no sign of selective outcome reporting from the article }\end{array}$ \\
\hline Similarity of baseline characteristics? & Unclear & not mentioned \\
\hline Co-interventions avoided or similar? & No & $\begin{array}{l}\text { After surgery, patients in instrumented group wear cervical col- } \\
\text { lar for } 6 \text { weeks while patients in non-instrumented group wear } \\
\text { cervical collar for } 3 \text { months }\end{array}$ \\
\hline Compliance acceptable? & Yes & Surgery \\
\hline Timing outcome assessments similar? & Yes & $\begin{array}{l}\text { e.g. JOA and improving rate were assessed before and after } \\
\text { surgery for each group. Fusion rate was measured at } 3-6 \text { months } \\
\text { after surgery for each group. Disc height and cervical lordotic } \\
\text { alignment were assessed at last visit (10-28 months) for each } \\
\text { group }\end{array}$ \\
\hline
\end{tabular}

Porras-Estrada 2004

\begin{tabular}{ll}
\hline Methods & RCT, Method unclear \\
\hline Participants & $\begin{array}{l}\text { Inclusion: Myelopathy and radiculopathy } \\
\text { Exclusion: - }\end{array}$ \\
\hline Interventions & $\begin{array}{l}\text { 1: Threaded cylindrical Bovine allograft } \\
\text { 2: BAK-C cage }\end{array}$ \\
\hline Outcomes & $\begin{array}{l}\text { Radiological: Subsidence, angulation, fusion, pseudoarthrosis } \\
\text { Clinical: Categorical, Good, average, bad } \\
\text { Functional: - }\end{array}$ \\
\hline
\end{tabular}


Porras-Estrada 2004 (Continued)

\begin{tabular}{|c|c|c|}
\hline Notes & \multicolumn{2}{|c|}{$\begin{array}{l}\text { Diagnosis DD: MRI } \\
\text { Cause of pain: Myelopathy and radiculopathy } \\
\text { Levels: } 34 / 44(77 \%) \text { one level; } 10(23 \%) \text { two level }\end{array}$} \\
\hline \multicolumn{3}{|l|}{ Risk of bias } \\
\hline Item & Authors' judgement & Description \\
\hline Adequate sequence generation? & Unclear & Method not specified \\
\hline Allocation concealment? & Unclear & Not mentioned \\
\hline $\begin{array}{l}\text { Blinding? } \\
\text { All outcomes - patients? }\end{array}$ & Unclear & Not mentioned \\
\hline $\begin{array}{l}\text { Blinding? } \\
\text { All outcomes - outcome assessors? }\end{array}$ & Unclear & Not mentioned \\
\hline $\begin{array}{l}\text { Blinding? } \\
\text { All outcomes - care provider? }\end{array}$ & No & Not possible in surgical procedures \\
\hline $\begin{array}{l}\text { Incomplete outcome data addressed? } \\
\text { All outcomes - drop-outs? }\end{array}$ & Yes & No lost to follow-up \\
\hline $\begin{array}{l}\text { Incomplete outcome data addressed? } \\
\text { All outcomes - ITT analysis? }\end{array}$ & Yes & All patients analysed in randomised group \\
\hline Free of selective reporting? & Yes & All preoperative outcomes presented \\
\hline Similarity of baseline characteristics? & Yes & All patients tabulated and groups comparable \\
\hline Co-interventions avoided or similar? & Yes & No co-interventions \\
\hline Compliance acceptable? & Yes & All treatments remained in place \\
\hline Timing outcome assessments similar? & Unclear & $\begin{array}{l}\text { Follow-up ranges from } 2 \text { to } 5 \text { years, no further information } \\
\text { given }\end{array}$ \\
\hline
\end{tabular}

Rosenorn 1983

\begin{tabular}{ll}
\hline Methods & RCT, method unclear \\
\hline Participants & $\begin{array}{l}\text { Herniated cervical discs, age from 20-70 years. } \\
\text { Exclusion: fractures, dislocations, Osteochondrosis with narrowing of foramina }\end{array}$ \\
\hline Interventions & $\begin{array}{l}\text { 1: Discectomy according to Hirsh } \\
\text { 2: Discectomy and fusion according to Cloward with freeze dried bone grafts }\end{array}$ \\
\hline
\end{tabular}


Rosenorn 1983 (Continued)

\begin{tabular}{|c|c|c|}
\hline Outcomes & \multicolumn{2}{|c|}{$\begin{array}{l}\text { Radiological: - } \\
\text { Clinical: custom criteria } \\
\text { Functional: Occupation }\end{array}$} \\
\hline Notes & \multicolumn{2}{|c|}{$\begin{array}{l}5 \text { surgeons } \\
\text { Diagnosis DD: Myelography with Pantopoqaque } \\
\text { Cause of pain: Herniated disc } \\
\text { Levels: } 40 / 63(64 \%) \text { one level; } 23 \text { (36\%) two level }\end{array}$} \\
\hline \multicolumn{3}{|l|}{ Risk of bias } \\
\hline Item & Authors' judgement & Description \\
\hline Adequate sequence generation? & Unclear & The randomisation technique was not described \\
\hline Allocation concealment? & Unclear & B - Unclear \\
\hline $\begin{array}{l}\text { Blinding? } \\
\text { All outcomes - patients? }\end{array}$ & No & \\
\hline $\begin{array}{l}\text { Blinding? } \\
\text { All outcomes - outcome assessors? }\end{array}$ & No & \\
\hline $\begin{array}{l}\text { Blinding? } \\
\text { All outcomes - care provider? }\end{array}$ & No & Not possible in surgical procedures \\
\hline $\begin{array}{l}\text { Incomplete outcome data addressed? } \\
\text { All outcomes - drop-outs? }\end{array}$ & Yes & \\
\hline $\begin{array}{l}\text { Incomplete outcome data addressed? } \\
\text { All outcomes - ITT analysis? }\end{array}$ & Yes & \\
\hline Free of selective reporting? & Unclear & Outcome parameters not clearly described prospectively \\
\hline Similarity of baseline characteristics? & Unclear & Unclear from text \\
\hline Co-interventions avoided or similar? & Yes & \\
\hline Compliance acceptable? & Yes & \\
\hline Timing outcome assessments similar? & Yes & \\
\hline
\end{tabular}




\begin{tabular}{ll}
\hline Methods & RCT, Method unclear \\
\hline Participants & $\begin{array}{l}\text { Inclusion: Unilateral radiculopathy with arm pain, MRI/CT mediolateral HNP, C2/3 } \\
\text { to c7/th1, Ventral }>4 \mathrm{~mm} \text { disc height } \\
\text { Exclusion: Foramnial HNP, Craniocaudal sequestration }>1 / 2 \text { vertebral body, instabilities } \\
\text { /deformities, Isolated neck pain, Foraminal stenosis without HNP, Previous operation } \\
\text { same segment }\end{array}$ \\
\hline Interventions & $\begin{array}{l}\text { 1: Peek cage with Microsurgical decompression } \\
\text { 2: Full endoscopic anterior decompression }\end{array}$ \\
\hline Outcomes & $\begin{array}{l}\text { Radiological: MRI/CT } \\
\text { Clinical: VAS arm neck, Hilbrand, NASS, Blood loss, Oper time } \\
\text { Functional: - }\end{array}$ \\
\hline Notes & $\begin{array}{l}\text { Diagnosis DD: MRI/CT } \\
\text { Cause of pain: Radiculopathy } \\
\text { Levels: } 120 \text { (100\%) one level }\end{array}$ \\
\hline
\end{tabular}

\section{Risk of bias}

\begin{tabular}{|c|c|c|}
\hline Item & Authors' judgement & Description \\
\hline Adequate sequence generation? & Unclear & Block randomisation, but procedure not mentioned \\
\hline Allocation concealment? & Unclear & Allocation disclosure not mentioned \\
\hline $\begin{array}{l}\text { Blinding? } \\
\text { All outcomes - patients? }\end{array}$ & No & Not possible due to different surgical technique \\
\hline $\begin{array}{l}\text { Blinding? } \\
\text { All outcomes - outcome assessors? }\end{array}$ & Yes & $\begin{array}{l}\text { Unclear, statement: "later examiners were not informed about } \\
\text { which operation procedure was used" }\end{array}$ \\
\hline $\begin{array}{l}\text { Blinding? } \\
\text { All outcomes - care provider? }\end{array}$ & No & Not possible \\
\hline $\begin{array}{l}\text { Incomplete outcome data addressed? } \\
\text { All outcomes - drop-outs? }\end{array}$ & Yes & $\mathrm{LTF}=17 \%$ \\
\hline $\begin{array}{l}\text { Incomplete outcome data addressed? } \\
\text { All outcomes - ITT analysis? }\end{array}$ & Unclear & $\begin{array}{l}\text { Not stated where } 3 \text { patients from FACD receiving ACDF were } \\
\text { analysed }\end{array}$ \\
\hline Free of selective reporting? & Yes & all parameters accounted for \\
\hline Similarity of baseline characteristics? & Yes & similar \\
\hline Co-interventions avoided or similar? & No & cage used in one group, ignored in comparison evaluation \\
\hline
\end{tabular}


Ruetten 2009 (Continued)

\begin{tabular}{lll}
\hline Compliance acceptable? & Yes & implant present \\
\hline Timing outcome assessments similar? & Yes & clear time-points \\
\hline
\end{tabular}

Ryu 2006

\begin{tabular}{ll}
\hline Methods & RCT, Method unclear \\
\hline Participants & $\begin{array}{l}\text { Inclusion: age 18-70, DDD, } 1 \text { or 2 levels, } 6 \text { weeks conservative treatment, cervicalgia/ } \\
\text { radiculopathy } \\
\text { Exclusion: Prior cervical spine surgery, Instability secondary to trauma, Lumbar Spine } \\
\text { disability, History of disc/spine infection, Spine tumour, Osteoporosis/metabolic bone } \\
\text { disease, Pregnancy, Significant illness, Psychological disturbance }\end{array}$ \\
\hline Interventions & $\begin{array}{l}\text { 1: DOC (Depuy) or PEAK (DePuy), Allograft } \\
\text { 2: I/F cage (DePuy), IC autograft }\end{array}$ \\
\hline Outcomes & $\begin{array}{l}\text { Radiological: Fusion AP, Instability F/E } \\
\text { Clinical: pain } \\
\text { Functional: NDI, Satisfaction, SF36 }\end{array}$ \\
\hline Notes & $\begin{array}{l}\text { Diagnosis DD: MRI } \\
\text { Cause of pain: Radiculopathy } \\
\text { Levels: 21/40 (53\%) one level; 19 (47\%) two level }\end{array}$ \\
\hline
\end{tabular}

Risk of bias

\begin{tabular}{l|l|l}
\hline Item & Authors' judgement & Description \\
\hline Adequate sequence generation? & Unclear & Not described \\
\hline Allocation concealment? & Unclear & Not described \\
\hline $\begin{array}{l}\text { Blinding? } \\
\text { All outcomes - patients? }\end{array}$ & No & \\
\hline $\begin{array}{l}\text { Blinding? } \\
\text { All outcomes - outcome assessors? }\end{array}$ & No & Not possible in surgical procedures \\
\hline $\begin{array}{l}\text { Blinding? } \\
\text { All outcomes - care provider? }\end{array}$ & No & \\
\hline $\begin{array}{l}\text { Incomplete outcome data addressed? } \\
\text { All outcomes - drop-outs? }\end{array}$ & Yes & \\
\hline $\begin{array}{l}\text { Incomplete outcome data addressed? } \\
\text { All outcomes - ITT analysis? }\end{array}$ & Yes & \\
\hline
\end{tabular}


Ryu 2006 (Continued)

\begin{tabular}{ll}
\hline Free of selective reporting? & Yes \\
\hline Similarity of baseline characteristics? & Yes \\
\hline Co-interventions avoided or similar? & Yes \\
\hline Compliance acceptable? & Yes \\
\hline Timing outcome assessments similar? & Yes \\
\hline
\end{tabular}

Savolainen 1998

\begin{tabular}{|c|c|c|}
\hline Methods & \multicolumn{2}{|l|}{ RCT, method unclear } \\
\hline Participants & \multicolumn{2}{|c|}{$\begin{array}{l}\text { Single level cervical disc disease, radicular symptoms, evidenced by radiological study, } \\
\text { long lasting severe radicular pain }\end{array}$} \\
\hline Interventions & \multicolumn{2}{|c|}{$\begin{array}{l}\text { 1: Discectomy } \\
\text { 2: Discectomy and fusion }(S+R) \\
\text { 3: Discectomy and fusion (Plating) }\end{array}$} \\
\hline Outcomes & \multicolumn{2}{|c|}{$\begin{array}{l}\text { Radiological: Kyphosis, fusion } \\
\text { Clinical: Custom: good/fair/poor }\end{array}$} \\
\hline Notes & \multicolumn{2}{|c|}{$\begin{array}{l}\text { No exclusion criteria } \\
\text { Diagnosis DD: Myelograph, MRI } \\
\text { Cause of pain: nerve root compression } \\
\text { Levels: } 91(100 \%) \text { one level }\end{array}$} \\
\hline \multicolumn{3}{|l|}{ Risk of bias } \\
\hline Item & Authors' judgement & Description \\
\hline Adequate sequence generation? & Unclear & The randomisation technique is not clear. \\
\hline Allocation concealment? & Unclear & Not described \\
\hline $\begin{array}{l}\text { Blinding? } \\
\text { All outcomes - patients? }\end{array}$ & No & \\
\hline $\begin{array}{l}\text { Blinding? } \\
\text { All outcomes - outcome assessors? }\end{array}$ & No & \\
\hline $\begin{array}{l}\text { Blinding? } \\
\text { All outcomes - care provider? }\end{array}$ & No & Not possible in surgical procedures \\
\hline
\end{tabular}


Savolainen 1998 (Continued)

\begin{tabular}{|c|c|c|}
\hline $\begin{array}{l}\text { Incomplete outcome data addressed? } \\
\text { All outcomes - drop-outs? }\end{array}$ & Yes & \\
\hline $\begin{array}{l}\text { Incomplete outcome data addressed? } \\
\text { All outcomes - ITT analysis? }\end{array}$ & Yes & \\
\hline Free of selective reporting? & Unclear & Outcome parameters not described clearly prospectively \\
\hline Similarity of baseline characteristics? & Yes & \\
\hline Co-interventions avoided or similar? & Yes & \\
\hline Compliance acceptable? & Yes & \\
\hline Timing outcome assessments similar? & Yes & \\
\hline
\end{tabular}

Schroder 2007

\begin{tabular}{|c|c|c|}
\hline Methods & \multicolumn{2}{|c|}{ RCT, Method Block randomisation } \\
\hline Participants & \multicolumn{2}{|c|}{$\begin{array}{l}\text { Inclusion: age 18-65, monoradicular syndrome, herniated cervical disc } \\
\text { Exclusion: Excessive osteophytes, Adjacent level degeneration, Myelopathy }\end{array}$} \\
\hline Interventions & \multicolumn{2}{|c|}{$\begin{array}{l}\text { 1: PMMA (Palacos) } \\
\text { 2: Cage (Intromed intervertebral spacer, Intromed) }\end{array}$} \\
\hline Outcomes & \multicolumn{2}{|c|}{$\begin{array}{l}\text { Radiological: Fusion, alignment } \\
\text { Clinical: Duration procedure, Neurological impairment } \\
\text { Functional: Odom }\end{array}$} \\
\hline Notes & \multicolumn{2}{|c|}{ Level: $115(100 \%)$ one level } \\
\hline \multicolumn{3}{|l|}{ Risk of bias } \\
\hline Item & Authors' judgement & Description \\
\hline Adequate sequence generation? & Yes & Block randomisation \\
\hline Allocation concealment? & Unclear & Not described \\
\hline $\begin{array}{l}\text { Blinding? } \\
\text { All outcomes - patients? }\end{array}$ & Unclear & Not described \\
\hline $\begin{array}{l}\text { Blinding? } \\
\text { All outcomes - outcome assessors? }\end{array}$ & No & \\
\hline
\end{tabular}


Schroder 2007 (Continued)

\begin{tabular}{|c|c|c|}
\hline $\begin{array}{l}\text { Blinding? } \\
\text { All outcomes - care provider? }\end{array}$ & No & Not possible in surgical procedures \\
\hline $\begin{array}{l}\text { Incomplete outcome data addressed? } \\
\text { All outcomes - drop-outs? }\end{array}$ & Yes & \\
\hline $\begin{array}{l}\text { Incomplete outcome data addressed? } \\
\text { All outcomes - ITT analysis? }\end{array}$ & Yes & \\
\hline Free of selective reporting? & Yes & \\
\hline Similarity of baseline characteristics? & Yes & \\
\hline Co-interventions avoided or similar? & Yes & \\
\hline Compliance acceptable? & Yes & \\
\hline Timing outcome assessments similar? & Yes & \\
\hline
\end{tabular}

Stulik 2007

\begin{tabular}{ll}
\hline Methods & RCT, Method \\
\hline Participants & $\begin{array}{l}\text { Inclusion: Sympt DDD, 1-2 levels, traumatic disco-ligamentous injuries, no previous } \\
\text { cervical spine surgery, not pregnant, age 21-80, informed consent } \\
\text { Exclusion: Previous cervical spine surgery, Additional cervical spine surgery, Infection, } \\
\text { AIDS, Hepatitis C, Osteoporosis, Malignancy, Mental disease, Sensititvity to materials, } \\
\text { Continuous use of steroids }\end{array}$ \\
\hline Interventions & $\begin{array}{l}\text { 1: Dynamic plate (ABC plate \& screws, Aesculaep), autograft } \\
\text { 2: Static plate (CSLP, Synthes), autograft }\end{array}$ \\
\hline Outcomes & $\begin{array}{l}\text { Radiological: Fusion } \\
\text { Clinical: None } \\
\text { Functional: None }\end{array}$ \\
\hline Notes & $\begin{array}{l}\text { Diagnosis DD: Unclear } \\
\text { Cause of pain: DDD } \\
\text { Levels: 91/132 (69\%) one level; 41 (31\%) two level }\end{array}$ \\
\hline
\end{tabular}

\section{Risk of bias}

\begin{tabular}{lll}
\hline Item & Authors' judgement & Description \\
\hline Adequate sequence generation? & Unclear & Not described \\
\hline Allocation concealment? & Unclear & Not described
\end{tabular}


Stulik 2007 (Continued)

\begin{tabular}{l|l|l}
\hline $\begin{array}{l}\text { Blinding? } \\
\text { All outcomes - patients? }\end{array}$ & Unclear & Not described \\
\hline $\begin{array}{l}\text { Blinding? } \\
\text { All outcomes - outcome assessors? }\end{array}$ & No & Not possible in surgical procedures \\
\hline $\begin{array}{l}\text { Blinding? } \\
\text { All outcomes - care provider? }\end{array}$ & No & \\
\hline $\begin{array}{l}\text { Incomplete outcome data addressed? } \\
\text { All outcomes - drop-outs? }\end{array}$ & No & \\
\hline $\begin{array}{l}\text { Incomplete outcome data addressed? } \\
\text { All outcomes - ITT analysis? }\end{array}$ & Yes \\
\hline Free of selective reporting? & Yes \\
\hline Similarity of baseline characteristics? & Yes \\
\hline Co-interventions avoided or similar? & Yes \\
\hline Compliance acceptable? & Yes \\
\hline \begin{tabular}{l} 
Timing outcome assessments similar? \\
\hline
\end{tabular} & Yes \\
\hline
\end{tabular}

Thome 2006

\begin{tabular}{ll}
\hline Methods & RCT, computer generated \\
\hline Participants & $\begin{array}{l}\text { Inclusion: Spondylosis, Herniated cervical disc, Conservative treatment } \\
\text { Exclusion: Ossification PLL, History of Cervical disc surgery, Spinal instability }\end{array}$ \\
\hline Interventions & $\begin{array}{l}\text { 1: Iliac crest autograft } \\
\text { 2: Rabea Cage (Signus) }\end{array}$ \\
\hline Outcomes & $\begin{array}{l}\text { Radiological: - } \\
\text { Clinical: VAS, Neurological status, } \\
\text { Functional: JOA, SF-36, Odom, PSI }\end{array}$ \\
\hline Notes & $\begin{array}{l}\text { Diagnosis DD: ? } \\
\text { Cause of pain: Spondylosis / Herniated disc } \\
\text { Levels: 73/100 (73\%) one level; 27 (27\%) two level }\end{array}$ \\
\hline
\end{tabular}

\section{Risk of bias}

Item

Authors' judgement

\section{Description}


Thome 2006 (Continued)

\begin{tabular}{|c|c|c|}
\hline Adequate sequence generation? & Yes & \\
\hline Allocation concealment? & Unclear & $\begin{array}{l}\text { Not described, Not sure what is meant by "concealed ran- } \\
\text { domisation" }\end{array}$ \\
\hline $\begin{array}{l}\text { Blinding? } \\
\text { All outcomes - patients? }\end{array}$ & Unclear & Not described \\
\hline $\begin{array}{l}\text { Blinding? } \\
\text { All outcomes - outcome assessors? }\end{array}$ & Unclear & Not described \\
\hline $\begin{array}{l}\text { Blinding? } \\
\text { All outcomes - care provider? }\end{array}$ & No & Not possible in surgical procedures \\
\hline $\begin{array}{l}\text { Incomplete outcome data addressed? } \\
\text { All outcomes - drop-outs? }\end{array}$ & Yes & \\
\hline $\begin{array}{l}\text { Incomplete outcome data addressed? } \\
\text { All outcomes - ITT analysis? }\end{array}$ & Yes & \\
\hline Free of selective reporting? & Yes & \\
\hline Similarity of baseline characteristics? & Yes & \\
\hline Co-interventions avoided or similar? & Yes & \\
\hline Compliance acceptable? & Yes & \\
\hline Timing outcome assessments similar? & Yes & \\
\hline
\end{tabular}

van den Bent 1996

\begin{tabular}{ll} 
Methods & RCT, block randomised with sealed envelopes \\
\hline Participants & $\begin{array}{l}\text { Cervical radicular syndrome caused by a herniated disc; } \\
\text { Failing to respond to conservative treatment } \\
\text { Exclusion: Disease interfering with follow-up, signs and symptoms of spinal cord com- } \\
\text { pression (GrII Nurick) }\end{array}$ \\
\hline Interventions & $\begin{array}{l}\text { 1: Discectomy }(S+R) \\
\text { 2: Discectomy (S+R) and fusion with PMMA }\end{array}$ \\
\hline Outcomes & $\begin{array}{l}\text { Radiological: Bony union, radiolucency } \\
\text { Clinical: Odom's criteria, neck pain and arm pain }\end{array}$ \\
\hline Notes & $\begin{array}{l}\text { Diagnosis DD: Myelograph, CT with intrathecal contrast } \\
\text { Cause of pain: Herniated intervertebral disc }\end{array}$
\end{tabular}




\section{Risk of bias}

\begin{tabular}{|c|c|c|}
\hline Item & Authors' judgement & Description \\
\hline Adequate sequence generation? & Yes & \\
\hline Allocation concealment? & Yes & \\
\hline $\begin{array}{l}\text { Blinding? } \\
\text { All outcomes - patients? }\end{array}$ & No & \\
\hline $\begin{array}{l}\text { Blinding? } \\
\text { All outcomes - outcome assessors? }\end{array}$ & No & \\
\hline $\begin{array}{l}\text { Blinding? } \\
\text { All outcomes - care provider? }\end{array}$ & No & Not possible in surgical procedures \\
\hline $\begin{array}{l}\text { Incomplete outcome data addressed? } \\
\text { All outcomes - drop-outs? }\end{array}$ & Yes & \\
\hline $\begin{array}{l}\text { Incomplete outcome data addressed? } \\
\text { All outcomes - ITT analysis? }\end{array}$ & Yes & \\
\hline Free of selective reporting? & No & \\
\hline Similarity of baseline characteristics? & Yes & \\
\hline Co-interventions avoided or similar? & Yes & \\
\hline Compliance acceptable? & Yes & \\
\hline Timing outcome assessments similar? & Yes & \\
\hline
\end{tabular}

Vavruch 2002

\begin{tabular}{ll}
\hline Methods & RCT, notes \\
\hline Participants & $\begin{array}{l}\text { More than } 6 \text { months of neck pain, radiculopathy of degenerative origin, compatible } \\
\text { MRI and clinical findings } \\
\text { Exclusion: Myelopathy, psychiatric disturbances, drug abuse, previous spine surgery }\end{array}$ \\
\hline Interventions & $\begin{array}{l}\text { Discectomy and fusion with iliac crest autograft } \\
\text { 1: with Cloward technique } \\
\text { 2: with } S+R \text { technique with Carbon fibre cage }\end{array}$
\end{tabular}


Vavruch 2002 (Continued)

\begin{tabular}{|c|c|c|}
\hline Outcomes & \multicolumn{2}{|c|}{$\begin{array}{l}\text { Radiological: Fusion } \\
\text { Clinical: Odom, VAS-pain } \\
\text { Functional: Neck Disability index, Cervical spine function score, Workstatus }\end{array}$} \\
\hline Notes & \multicolumn{2}{|c|}{$\begin{array}{l}\text { Diagnosis DD: MRI } \\
\text { Cause of pain: degenerative origin } \\
\text { Levels: } 58 / 89(65 \%) \text { one level; } 27 / 89(30 \%) \text { two level; } 4 / 89(5 \%) \text { three level }\end{array}$} \\
\hline \multicolumn{3}{|l|}{ Risk of bias } \\
\hline Item & Authors' judgement & Description \\
\hline Adequate sequence generation? & Yes & The randomisation technique is adequate \\
\hline Allocation concealment? & Yes & \\
\hline $\begin{array}{l}\text { Blinding? } \\
\text { All outcomes - patients? }\end{array}$ & No & \\
\hline $\begin{array}{l}\text { Blinding? } \\
\text { All outcomes - outcome assessors? }\end{array}$ & No & \\
\hline $\begin{array}{l}\text { Blinding? } \\
\text { All outcomes - care provider? }\end{array}$ & No & Not possible in surgical procedures \\
\hline $\begin{array}{l}\text { Incomplete outcome data addressed? } \\
\text { All outcomes - drop-outs? }\end{array}$ & Unclear & Unclear from text \\
\hline $\begin{array}{l}\text { Incomplete outcome data addressed? } \\
\text { All outcomes - ITT analysis? }\end{array}$ & Yes & \\
\hline Free of selective reporting? & Yes & \\
\hline Similarity of baseline characteristics? & Yes & \\
\hline Co-interventions avoided or similar? & Yes & \\
\hline Compliance acceptable? & Yes & \\
\hline Timing outcome assessments similar? & Yes & \\
\hline
\end{tabular}


Xie 2007

\begin{tabular}{ll}
\hline Methods & RCT, Method Computer generated randomisation matrix \\
\hline Participants & $\begin{array}{l}\text { Inclusion: Cervical radiculopathy, Single level, Degenerative disc disease, }>18 \text { years, } \\
\text { English speaking } \\
\text { Exclusion: Myelopathy, Multi level, Resection adjacent vertebral bodies, Posterior de- } \\
\text { generative changes, Comorbidity requiring narcotic analgesic }\end{array}$ \\
\hline Interventions & $\begin{array}{l}\text { 1: Discectomy alone } \\
\text { 2: Iliac crest autograft } \\
\text { 3: Codman plate (J\&J) with Iliac crest autograft }\end{array}$ \\
\hline Outcomes & $\begin{array}{l}\text { Radiological: Fusion, Alignment, Adjacent segment degeneration } \\
\text { Clinical: Mcgill pain } \\
\text { Functional: Sf 36, American spinal injury scale }\end{array}$ \\
\hline Notes & $\begin{array}{l}\text { Diagnosis DD: MRI, Radiology } \\
\text { Cause of pain: Radiculopathy/ DDD } \\
\text { Level: } 42 \text { (100\%) one level }\end{array}$ \\
\hline
\end{tabular}

\section{Risk of bias}

\begin{tabular}{|c|c|c|}
\hline Item & Authors' judgement & Description \\
\hline Adequate sequence generation? & Yes & Computer generated randomisation matrix \\
\hline Allocation concealment? & Unclear & Not described \\
\hline $\begin{array}{l}\text { Blinding? } \\
\text { All outcomes - patients? }\end{array}$ & No & \\
\hline $\begin{array}{l}\text { Blinding? } \\
\text { All outcomes - outcome assessors? }\end{array}$ & No & \\
\hline $\begin{array}{l}\text { Blinding? } \\
\text { All outcomes - care provider? }\end{array}$ & No & Not possible in surgical procedures \\
\hline $\begin{array}{l}\text { Incomplete outcome data addressed? } \\
\text { All outcomes - drop-outs? }\end{array}$ & No & \\
\hline $\begin{array}{l}\text { Incomplete outcome data addressed? } \\
\text { All outcomes - ITT analysis? }\end{array}$ & Yes & \\
\hline Free of selective reporting? & Yes & \\
\hline Similarity of baseline characteristics? & No & \\
\hline Co-interventions avoided or similar? & Yes & \\
\hline
\end{tabular}


Xie 2007 (Continued)

\begin{tabular}{ll}
\hline Compliance acceptable? & Yes \\
\hline Timing outcome assessments similar? & Yes \\
\hline
\end{tabular}

\section{Zoega 2000}

\begin{tabular}{ll}
\hline Methods & RCT, Sealed envelopes, day before \\
\hline Participants & Herniated disc or spondylosis at 1 or 2 levels \\
\hline Interventions & $\begin{array}{l}\text { Discectomy and fusion (S+R) with iliac crest autograft } \\
1: \text { with CSLP plate } \\
\text { 2: Without plate }\end{array}$ \\
\hline Outcomes & $\begin{array}{l}\text { Radiological: } \\
\text { Clinical: VAS neck and arm pain, Odom's criteria } \\
\text { Functional: Million index, Oswestry indexZung depression scale }\end{array}$ \\
\hline Notes & $\begin{array}{l}\text { No exclusion criteria } \\
\text { Diagnosis DD: MRI } \\
\text { Cause of pain: Radiculopathy } \\
\text { Levels: } 27 / 46 \text { (59\%) one level; } 19 \text { (41\%) two level }\end{array}$ \\
\hline
\end{tabular}

\section{Risk of bias}

\begin{tabular}{|c|c|c|}
\hline Item & Authors' judgement & Description \\
\hline Adequate sequence generation? & Yes & The randomisation technique is valid \\
\hline Allocation concealment? & Yes & \\
\hline $\begin{array}{l}\text { Blinding? } \\
\text { All outcomes - patients? }\end{array}$ & No & \\
\hline $\begin{array}{l}\text { Blinding? } \\
\text { All outcomes - outcome assessors? }\end{array}$ & Yes & \\
\hline $\begin{array}{l}\text { Blinding? } \\
\text { All outcomes - care provider? }\end{array}$ & No & Not possible in surgical procedures \\
\hline $\begin{array}{l}\text { Incomplete outcome data addressed? } \\
\text { All outcomes - drop-outs? }\end{array}$ & Yes & \\
\hline $\begin{array}{l}\text { Incomplete outcome data addressed? } \\
\text { All outcomes - ITT analysis? }\end{array}$ & Yes & \\
\hline Free of selective reporting? & Yes & \\
\hline
\end{tabular}


Zoega 2000 (Continued)

\begin{tabular}{ll}
\hline Similarity of baseline characteristics? & Yes \\
\hline Co-interventions avoided or similar? & Yes \\
\hline Compliance acceptable? & Yes \\
\hline Timing outcome assessments similar? & Yes \\
\hline
\end{tabular}

RCT $=$ Randomised Clinical Trial

$\mathrm{S}+\mathrm{R}=$ Smith and Robinson procedure

VAS=Visual analogue scale

DD: Degenerative disc

\section{Characteristics of excluded studies [ordered by study ID]}

\begin{tabular}{|c|c|}
\hline Study & Reason for exclusion \\
\hline An 1995 & Quasi RCT with patient preferences \\
\hline Barlocher 2000 & Conference proceeding, Journal version included \\
\hline Bishop 1996 & Quasi RCT; Alternating \\
\hline Bolesta 2002 & Not randomised \\
\hline Brown 1976 & Retrospective study \\
\hline Chen 2001 & Biomechanical Model \\
\hline Dunsker 1977 & Retrospective study \\
\hline Emery 1976 & not randomised \\
\hline Espersen 1984 & Retrospective study \\
\hline Grob 2001 & Quasi RCT; chronological \\
\hline Hedlund 2001 & Conference proceeding \\
\hline Herkowitz 1990 & Other comparison \\
\hline Iseda 2000 & Outcome parameter \\
\hline
\end{tabular}


(Continued)

\begin{tabular}{|c|c|}
\hline Iseda 2001 & Outcome parameter \\
\hline Jenis 2000 & Quasi RCT; alternating \\
\hline Jollenbeck 2001 & not randomised \\
\hline Kadanka 2000 & Other treatment comparison \\
\hline Lopez-Olivia 1998 & Retrospective \\
\hline Marks 1998 & Editorial \\
\hline Mayer 1998 & Matched comparison \\
\hline Murphy 1994 & Not randomised \\
\hline Pasciak 2005 & Not randomised, retrospective \\
\hline Persson 1997 & Other treatment comparison \\
\hline Persson 2001 & Other treatment comparison \\
\hline Rawlinson 1994 & quasi RCT; hospital file number \\
\hline Rish 1976 & Not randomised \\
\hline Shapiro 2001 & Not randomised \\
\hline Shin 2007 & not randomised \\
\hline Siddiqui 2003 & quasi RCT; Date of birth randomisation \\
\hline Suchomel 2004 & Patient preference allocation \\
\hline Theodore 2000 & Review \\
\hline Watters 1994 & Retrospective study \\
\hline Wigfield 2001 & Review \\
\hline Wigfield 2002 & Other treatment comparison \\
\hline Wigfield 2003 & "pre-randomisation" not allowed \\
\hline Wirth 2000 & Acute herniated discs: other indication \\
\hline Yamamoto 1978 & Not randomised \\
\hline
\end{tabular}




\section{Characteristics of studies awaiting assessment [ordered by study ID]}

\section{Nabhan 2009}

\begin{tabular}{|c|c|}
\hline Methods & RCT, method unclear. Allocation concealment by sealed envelopes. Blinding not mentioned \\
\hline Participants & $\begin{array}{l}\text { Single level, C3-C7, Soft or hard disc herniation, Symptomatic degenerative disc disease with radiculopathy not } \\
\text { responding to conservative therapy. Age } 20-60 \\
\text { Excluision: osteoporosis, infection, spondylodiscitis, malignancies, Hepatitis, HIV, AIDS, allergies, Spine injury, } \\
\text { pregnancy }\end{array}$ \\
\hline Interventions & $\begin{array}{l}\text { Peek Cage } \\
\text { 1: Dynamic titanium plate } \\
\text { 2: Biodegradable plate }\end{array}$ \\
\hline Outcomes & $\begin{array}{l}\text { Radiological: RSA motion } \\
\text { Clinical: VAS arm pain, NDI neck pain } \\
\text { Functional: - }\end{array}$ \\
\hline Notes & Levels: $40(100 \%)$ single level \\
\hline
\end{tabular}

\section{Pitzen 2009}

\begin{tabular}{ll}
\hline Methods & RCT, \\
\hline Participants & $\begin{array}{l}\text { Type A fractures, Symptomatic degenerative disc disease in } 1 \text { or } 2 \text { levels, Traumatic disco-ligamentous injuries, 21- } \\
80 \text { years } \\
\text { Exclusion: Previous C-spine surgery, Additional C-spine surgery (i.e., posterior approach), Active and suspected } \\
\text { infection, AIDS, Hepatitis C, Pregnancy, Severe osteoporosis, Known malignancy, Mental disease, Sensitivity to one } \\
\text { of the device materials, Continuous use of steroids }\end{array}$ \\
\hline Interventions & $\begin{array}{l}\text { Anterior discectomy with iliac crest autograft } \\
\text { 1: Dynamic plate } \\
\text { 2: Rigid plate }\end{array}$ \\
\hline Outcomes & $\begin{array}{l}\text { Preoperative, 3, } 6 \text { months, } 2 \text { years } \\
\text { Raiological: Motion on Flexion-Extension } \\
\text { Clinical: Implant complication } \\
\text { Functional: }-\end{array}$ \\
\hline Notes & \begin{tabular}{l} 
Levels: /132 (\%) one level \\
\hline
\end{tabular}
\end{tabular}


DATA AND ANALYSES

Comparison 1. Discectomy alone vs human bone graft

\begin{tabular}{|c|c|c|c|c|}
\hline Outcome or subgroup title & $\begin{array}{l}\text { No. of } \\
\text { studies }\end{array}$ & $\begin{array}{c}\text { No. of } \\
\text { participants }\end{array}$ & Statistical method & Effect size \\
\hline 1 Hospital stay & 4 & 300 & Std. Mean Difference (IV, Random, 95\% CI) & $-0.48[-1.01,0.05]$ \\
\hline 2 Operation time & 3 & 237 & Mean Difference (IV, Random, 95\% CI) & $\begin{array}{l}-23.71[-33.21,-14 \\
21]\end{array}$ \\
\hline 3 Blood loss & 1 & 63 & Mean Difference (IV, Random, 95\% CI) & $\begin{array}{l}-21.0[-28.68,-13 . \\
32]\end{array}$ \\
\hline 4 Pain not relieved at 5 weeks & 1 & 84 & Risk Ratio (M-H, Random, 95\% CI) & $0.83[0.20,3.46]$ \\
\hline 5 Odom's criteria & 2 & 149 & Risk Ratio (M-H, Random, 95\% CI) & $0.95[0.82,1.10]$ \\
\hline 6 Not Returned to work at 5 weeks & 2 & 144 & Risk Ratio (M-H, Random, 95\% CI) & $1.26[1.02,1.54]$ \\
\hline $\begin{array}{l}7 \text { Not Returned to work at } 10 \\
\text { weeks }\end{array}$ & 2 & 128 & Risk Ratio (M-H, Random, 95\% CI) & $1.44[0.77,2.69]$ \\
\hline 8 No Fusion & 5 & 303 & Risk Ratio (M-H, Random, 95\% CI) & $0.22[0.10,0.49]$ \\
\hline 9 Alignment & 2 & 75 & Risk Ratio (M-H, Random, 95\% CI) & $0.34[0.07,1.56]$ \\
\hline
\end{tabular}

Comparison 2. Discectomy alone vs cage or cement

\begin{tabular}{|c|c|c|c|c|}
\hline Outcome or subgroup title & $\begin{array}{l}\text { No. of } \\
\text { studies }\end{array}$ & $\begin{array}{c}\text { No. of } \\
\text { participants }\end{array}$ & Statistical method & Effect size \\
\hline 1 Operation time & 3 & 334 & Mean Difference (IV, Random, 95\% CI) & $8.74[-8.21,25.69]$ \\
\hline 1.1 Discectomy alone vs cage & 3 & 275 & Mean Difference (IV, Random, 95\% CI) & $9.49[-13.66,32.64]$ \\
\hline $\begin{array}{l}1.2 \text { Discectomy alone vs } \\
\text { PMMA }\end{array}$ & 1 & 59 & Mean Difference (IV, Random, 95\% CI) & $6.40[0.53,12.27]$ \\
\hline 2 Blood loss & 1 & 128 & Mean Difference (IV, Random, 95\% CI) & $11.32[6.27,16.36]$ \\
\hline 2.1 Discectomy alone vs cage & 1 & 69 & Mean Difference (IV, Random, 95\% CI) & $13.10[6.61,19.59]$ \\
\hline $\begin{array}{l}\text { 2.2 Discectomy alone vs } \\
\text { PMMA }\end{array}$ & 1 & 59 & Mean Difference (IV, Random, 95\% CI) & $8.60[0.58,16.62]$ \\
\hline 3 Length of stay & 1 & 118 & Mean Difference (IV, Random, 95\% CI) & $-0.70[-1.30,-0.09]$ \\
\hline 3.1 Discectomy alone vs cage & 1 & 59 & Mean Difference (IV, Random, 95\% CI) & $-0.60[-1.43,0.23]$ \\
\hline $\begin{array}{l}3.2 \text { Discectomy alone vs } \\
\text { PMMA }\end{array}$ & 1 & 59 & Mean Difference (IV, Random, 95\% CI) & $-0.80[-1.67,0.07]$ \\
\hline 4 Recovery & 1 & 79 & Risk Ratio (M-H, Random, 95\% CI) & $1.12[0.91,1.38]$ \\
\hline 4.1 Discectomy alone vs cages & 1 & 79 & Risk Ratio (M-H, Random, 95\% CI) & $1.12[0.91,1.38]$ \\
\hline $\begin{array}{l}5 \text { Neck pain not relieved at } 6 \\
\text { weeks }\end{array}$ & 2 & & Risk Ratio (M-H, Random, 95\% CI) & Subtotals only \\
\hline $\begin{array}{l}5.1 \text { Discectomy alone vs } \\
\text { cement }\end{array}$ & 2 & 140 & Risk Ratio (M-H, Random, 95\% CI) & $0.75[0.21,2.66]$ \\
\hline 6 Neck pain not relieved at 2 years & 2 & & Risk Ratio (M-H, Random, 95\% CI) & Subtotals only \\
\hline $\begin{array}{l}6.1 \text { Discectomy alone vs } \\
\text { cement }\end{array}$ & 2 & 135 & Risk Ratio (M-H, Random, 95\% CI) & $1.05[0.69,1.61]$ \\
\hline 7 VAS Arm pain 24 months & 1 & 103 & Mean Difference (IV, Random, 95\% CI) & Not estimable \\
\hline
\end{tabular}

Single or double-level anterior interbody fusion techniques for cervical degenerative disc disease (Review)

Copyright (@) 20II The Cochrane Collaboration. Published by John Wiley \& Sons, Ltd. 


\begin{tabular}{|c|c|c|c|c|}
\hline $\begin{array}{l}\text { 7.1 Discectomy alone versus } \\
\text { cage }\end{array}$ & 1 & 103 & Mean Difference (IV, Random, 95\% CI) & Not estimable \\
\hline 8 VAS Neck pain 24 months & 1 & 103 & Mean Difference (IV, Random, 95\% CI) & Not estimable \\
\hline $\begin{array}{l}8.1 \text { Discectomy alone versus } \\
\text { cage }\end{array}$ & 1 & 103 & Mean Difference (IV, Random, 95\% CI) & Not estimable \\
\hline 9 NASS pain 24 months & 1 & 103 & Mean Difference (IV, Random, 95\% CI) & Not estimable \\
\hline 9.1 Discectomy alone vs cage & 1 & 103 & Mean Difference (IV, Random, 95\% CI) & Not estimable \\
\hline 10 NASS neurology 24 months & 1 & 103 & Mean Difference (IV, Random, 95\% CI) & Not estimable \\
\hline $\begin{array}{l}\text { 10.1 Discectomy alone versus } \\
\text { cage }\end{array}$ & 1 & 103 & Mean Difference (IV, Random, 95\% CI) & Not estimable \\
\hline 11 No Fusion & 4 & & Risk Ratio (M-H, Random, 95\% CI) & Subtotals only \\
\hline $\begin{array}{l}11.1 \text { Discectomy alone vs } \\
\text { cement }\end{array}$ & 2 & 131 & Risk Ratio (M-H, Random, 95\% CI) & $4.75[0.58,38.67]$ \\
\hline 11.2 Discectomy alone vs cage & 3 & 250 & Risk Ratio (M-H, Random, 95\% CI) & $0.65[0.09,4.42]$ \\
\hline 12 Odom's criteria & & & Other data & No numeric data \\
\hline 12.1 Discectomy alone vs cage & & & Other data & No numeric data \\
\hline $\begin{array}{l}\text { 12.2 Discectomy alone vs } \\
\text { PMMA }\end{array}$ & & & Other data & No numeric data \\
\hline
\end{tabular}

Comparison 3. Discectomy alone vs human bone graft with plates

\begin{tabular}{lccll} 
Outcome or subgroup title & $\begin{array}{c}\text { No. of } \\
\text { studies }\end{array}$ & $\begin{array}{c}\text { No. of } \\
\text { participants }\end{array}$ & \multicolumn{1}{c}{ Statistical method } & Effect size \\
\hline 1 VAS Arm pain & 1 & 20 & Mean Difference (IV, Random, 95\% CI) & $-0.16[-0.85,0.53]$ \\
2 VAS neck pain & 1 & 20 & Mean Difference (IV, Random, 95\% CI) & $-0.81[-1.42,-0.20]$ \\
3 Disc height & 1 & 20 & Mean Difference (IV, Random, 95\% CI) & $1.33[0.57,2.09]$ \\
4 Odoms criteria & 1 & 60 & Risk Ratio (M-H, Random, 95\% CI) & $0.96[0.71,1.28]$ \\
5 Fusion & 2 & 76 & Risk Ratio (M-H, Fixed, 95\% CI) & $1.10[0.96,1.27]$ \\
\hline
\end{tabular}

Comparison 4. Iliac crest autograft vs human allograft or bone substitute

\begin{tabular}{lccll} 
Outcome or subgroup title & $\begin{array}{c}\text { No. of } \\
\text { studies }\end{array}$ & $\begin{array}{c}\text { No. of } \\
\text { participants }\end{array}$ & Statistical method & Effect size \\
\hline 1 headache & 1 & 27 & Mean Difference (IV, Random, 95\% CI) & $18.0[4.77,31.23]$ \\
2 Sensory function & 1 & 27 & Mean Difference (IV, Random, 95\% CI) & $15.0[2.07,27.93]$ \\
3 Muscle power & 1 & 27 & Mean Difference (IV, Random, 95\% CI) & $27.0[11.48,42.52]$ \\
4 Odoms criteria & 1 & 115 & Risk Ratio (M-H, Random, 95\% CI) & $0.94[0.77,1.15]$ \\
\hline
\end{tabular}


Comparison 5. Iliac crest autograft vs cage

\begin{tabular}{lccll} 
Outcome or subgroup title & $\begin{array}{c}\text { No. of } \\
\text { studies }\end{array}$ & $\begin{array}{c}\text { No. of } \\
\text { participants }\end{array}$ & \multicolumn{1}{c}{ Statistical method } & \multicolumn{1}{c}{ Effect size } \\
\hline 1 Operation time & 3 & 200 & Mean Difference (IV, Random, 95\% CI) & $\begin{array}{l}-13.21[-29.99,3 . \\
\text { 2 }\end{array}$ \\
2 Blood loss & 2 & 120 & Mean Difference (IV, Random, 95\% CI) & $-8.05[-15.30,-0.79]$ \\
3 Hospital stay & 3 & 211 & Mean Difference (IV, Random, 95\% CI) & $-0.42[-0.84,0.01]$ \\
4 VAS Neck Pain & 3 & 275 & Mean Difference (IV, Random, 95\% CI) & $0.40[-0.94,1.73]$ \\
5 VAS Arm pain & 2 & 180 & Mean Difference (IV, Random, 95\% CI) & $-0.29[-0.90,0.33]$ \\
6 Neck Disability Index (NDI) & 2 & 175 & Mean Difference (IV, Random, 95\% CI) & $1.47[-5.39,8.33]$ \\
7 JOA & 1 & 100 & Mean Difference (IV, Random, 95\% CI) & $-0.10[-0.79,0.59]$ \\
8 Odom's criteria & 6 & 412 & Risk Ratio (M-H, Fixed, 95\% CI) & $1.11[0.99,1.24]$ \\
9 SF-36 Physical & 1 & 54 & Mean Difference (IV, Fixed, 95\% CI) & $2.30[-4.57,9.17]$ \\
10 SF-36 Mental & 1 & 54 & Mean Difference (IV, Random, 95\% CI) & $5.80[-1.32,12.92]$ \\
11 Satisfaction & 1 & 488 & Risk Ratio (M-H, Random, 95\% CI) & $0.98[0.88,1.08]$ \\
12 Foraminal height & 1 & 65 & Mean Difference (IV, Random, 95\% CI) & $1.5[0.83,2.17]$ \\
13 Interspace height & 1 & 65 & Mean Difference (IV, Random, 95\% CI) & $1.9[1.17,2.63]$ \\
14 Cobb angle & 1 & 65 & Mean Difference (IV, Random, 95\% CI) & $0.80[-0.92,2.52]$ \\
15 No Fusion & 5 & 424 & Risk Ratio (M-H, Random, 95\% CI) & $1.87[1.10,3.17]$ \\
\hline
\end{tabular}

Comparison 6. Iliac crest autograft vs iliac crest autograft with plates

\begin{tabular}{lcclc} 
Outcome or subgroup title & $\begin{array}{c}\text { No. of } \\
\text { studies }\end{array}$ & $\begin{array}{c}\text { No. of } \\
\text { participants }\end{array}$ & \multicolumn{1}{c}{ Statistical method } & Effect size \\
\hline 1 Clinical outcome & 2 & 104 & Risk Ratio (M-H, Fixed, 95\% CI) & $1.14[0.91,1.41]$ \\
2 No Fusion & 2 & 76 & Risk Ratio (M-H, Random, 95\% CI) & $0.99[0.92,1.07]$ \\
\hline
\end{tabular}

Comparison 7. Different types of autograft

\begin{tabular}{lcccc} 
Outcome or subgroup title & $\begin{array}{c}\text { No. of } \\
\text { studies }\end{array}$ & $\begin{array}{c}\text { No. of } \\
\text { participants }\end{array}$ & Statistical method & Effect size \\
\hline 1 Fusion & 1 & 50 & Risk Ratio (M-H, Random, 95\% CI) & $0.61[0.32,1.17]$ \\
\hline
\end{tabular}


Comparison 9. Other comparisons between different types of instrumentation

\begin{tabular}{lcccc} 
Outcome or subgroup title & $\begin{array}{c}\text { No. of } \\
\text { studies }\end{array}$ & $\begin{array}{c}\text { No. of } \\
\text { participants }\end{array}$ & Statistical method & Effect size \\
\hline 1 Odom's criteria & 1 & 107 & Risk Ratio (M-H, Random, 95\% CI) & $1.09[0.91,1.31]$ \\
\hline
\end{tabular}

\section{Comparison 10. PMMA vs cage}

\begin{tabular}{lccll} 
Outcome or subgroup title & $\begin{array}{c}\text { No. of } \\
\text { studies }\end{array}$ & $\begin{array}{c}\text { No. of } \\
\text { participants }\end{array}$ & \multicolumn{1}{c}{ Statistical method } & Effect size \\
\hline 1 Operation time & 2 & 169 & Mean Difference (IV, Random, 95\% CI) & $13.49[8.23,18.75]$ \\
2 Odoms criteria & 2 & 167 & Risk Ratio (M-H, Random, 95\% CI) & $1.00[0.85,1.19]$ \\
3 No Fusion & 2 & 167 & Risk Ratio (M-H, Random, 95\% CI) & $7.25[0.70,74.75]$ \\
\hline
\end{tabular}

Comparison 11. Cage vs cage and plate

\begin{tabular}{lccccc} 
Outcome or subgroup title & $\begin{array}{c}\text { No. of } \\
\text { studies }\end{array}$ & $\begin{array}{c}\text { No. of } \\
\text { participants }\end{array}$ & \multicolumn{2}{c}{ Statistical method } \\
\hline 1 Neck pain & 1 & 37 & Mean Difference (IV, Random, 95\% CI) & $0.30[0.03,0.57]$ \\
2 Arm pain & 1 & 37 & Mean Difference (IV, Random, 95\% CI) & $-0.60[-0.80,-0.40]$ \\
3 JOA & 1 & 62 & Mean Difference (IV, Random, 95\% CI) & $0.5[-0.65,1.65]$ \\
4 Segmental lordosis & 1 & 62 & Mean Difference (IV, Random, 95\% CI) & $-0.60[-2.95,1.75]$ \\
\hline
\end{tabular}

Comparison 12. Complications

\begin{tabular}{|c|c|c|c|c|}
\hline Outcome or subgroup title & $\begin{array}{l}\text { No. of } \\
\text { studies }\end{array}$ & $\begin{array}{c}\text { No. of } \\
\text { participants }\end{array}$ & Statistical method & Effect size \\
\hline 1 complications & 33 & 2595 & Risk Ratio (M-H, Fixed, 95\% CI) & $0.72[0.49,1.06]$ \\
\hline $\begin{array}{l}\text { 1.1 Discectomy alone versus } \\
\text { human bone graft }\end{array}$ & 7 & 442 & Risk Ratio (M-H, Fixed, 95\% CI) & $1.56[0.71,3.43$ \\
\hline 1.2 Discectomy alone vs cage & 3 & 260 & Risk Ratio (M-H, Fixed, 95\% CI) & $0.18[0.01,3.69]$ \\
\hline $\begin{array}{l}\text { 1.3 Discectomy alone vs } \\
\text { PMMA }\end{array}$ & 2 & 140 & Risk Ratio (M-H, Fixed, 95\% CI) & $0.25[0.01,5.03]$ \\
\hline $\begin{array}{l}1.4 \text { Discectomy alone vs iliac } \\
\text { crest autograft with plates }\end{array}$ & 3 & 111 & Risk Ratio (M-H, Fixed, 95\% CI) & $1.03[0.33,3.21]$ \\
\hline 1.5 Autograft versus Allograft & 4 & 220 & Risk Ratio (M-H, Fixed, 95\% CI) & $1.08[0.34,3.48]$ \\
\hline $\begin{array}{l}\text { 1.6 Autograft vs autograft w } \\
\text { cages }\end{array}$ & 7 & 492 & Risk Ratio (M-H, Fixed, 95\% CI) & $0.33[0.12,0.92]$ \\
\hline
\end{tabular}

Single or double-level anterior interbody fusion techniques for cervical degenerative disc disease (Review)

Copyright (C) 201 I The Cochrane Collaboration. Published by John Wiley \& Sons, Ltd. 


$\begin{array}{lcccc}\begin{array}{l}1.7 \text { Iliac crest autograft vs iliac } \\ \text { crest autograft and plates }\end{array} & 3 & 136 & \text { Risk Ratio (M-H, Fixed, 95\% CI) } & 0.99[0.37,2.63] \\ \begin{array}{l}1.8 \text { Different types of } \\ \text { autograft }\end{array} & 1 & 46 & \text { Risk Ratio (M-H, Fixed, 95\% CI) } & 0.23[0.05,1.08] \\ \begin{array}{l}1.9 \text { Bone substitute vs bone } \\ \text { substitute w cages }\end{array} & 1 & 44 & \text { Risk Ratio (M-H, Fixed, 95\% CI) } & 0.33[0.01,7.76] \\ \begin{array}{l}1.10 \text { Conservative } \\ \text { instrumentation verus } \\ \text { innovational instrumentation }\end{array} & 10 & 704 & \text { Risk Ratio (M-H, Fixed, 95\% CI) } & 0.10[0.01,1.85] \\ \end{array}$

\section{Analysis I.I. Comparison I Discectomy alone vs human bone graft, Outcome I Hospital stay.}

Review: Single or double-level anterior interbody fusion techniques for cervical degenerative disc disease

Comparison: I Discectomy alone vs human bone graft

Outcome: I Hospital stay

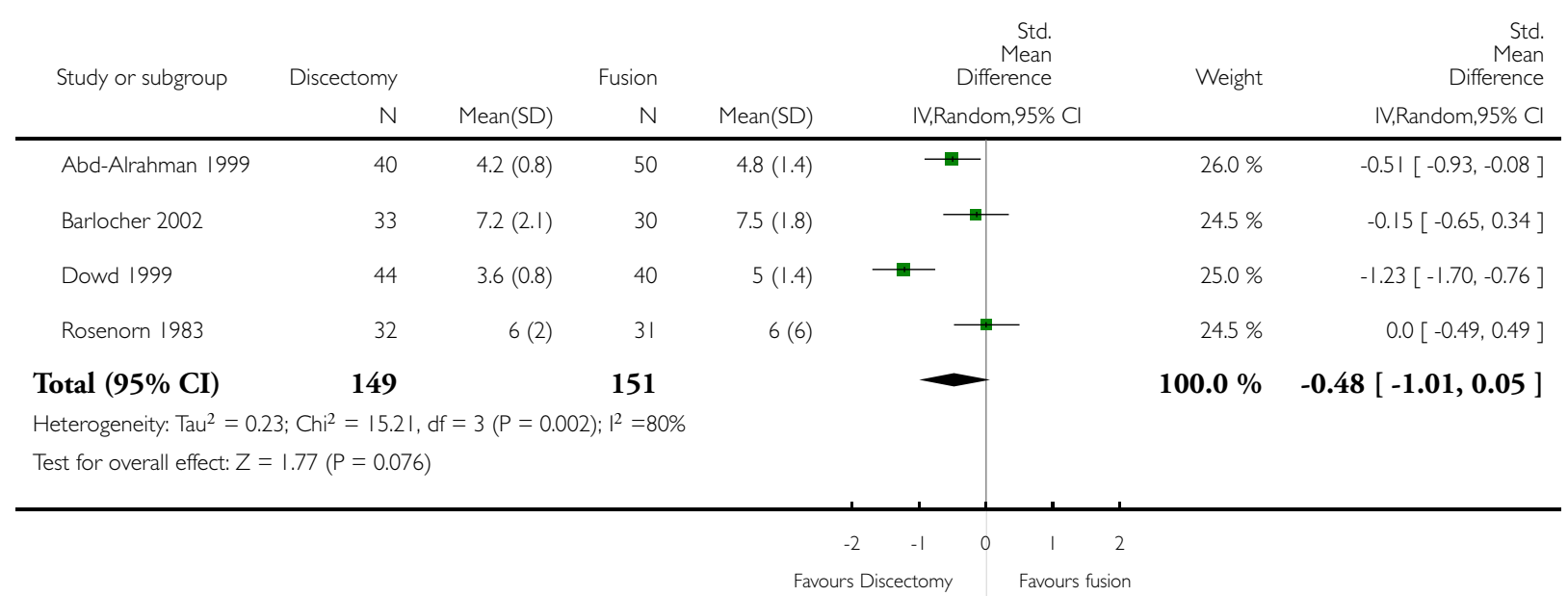


Analysis I.2. Comparison I Discectomy alone vs human bone graft, Outcome 2 Operation time.

Review: Single or double-level anterior interbody fusion techniques for cervical degenerative disc disease

Comparison: I Discectomy alone vs human bone graft

Outcome: 2 Operation time

\begin{tabular}{|c|c|c|c|c|c|c|c|c|}
\hline \multirow{3}{*}{$\begin{array}{l}\text { Study or subgroup } \\
\text { Abd-Alrahman } 1999\end{array}$} & \multirow{3}{*}{$\begin{array}{r}\text { Discectomy } \\
\text { N } \\
40\end{array}$} & \multirow{3}{*}{\multicolumn{2}{|c|}{$\begin{array}{r}\text { fusion } \\
\mathrm{N} \\
50\end{array}$}} & \multirow{2}{*}{\multicolumn{3}{|c|}{$\begin{array}{c}\text { Mean } \\
\text { Difference } \\
\text { IV,Random,95\% Cl }\end{array}$}} & \multirow[t]{2}{*}{ Weight } & \multirow{2}{*}{$\begin{array}{r}\text { Mean } \\
\text { Difference } \\
\text { IV,Random,95\% Cl }\end{array}$} \\
\hline & & & & & & & & \\
\hline & & & & $140(34)$ & 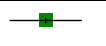 & & $27.0 \%$ & $-30.00[-43.02,-16.98]$ \\
\hline Barlocher 2002 & 33 & $82.6(11.2)$ & 30 & $99.8(9.8)$ & +1 & & $47.1 \%$ & $-17.20[-22.39,-12.01]$ \\
\hline Dowd 1999 & 44 & $102(29)$ & 40 & $131(34)$ & - & & $25.9 \%$ & $-29.00[-42.58,-15.42]$ \\
\hline Total (95\% CI) & 117 & & 120 & & & & $100.0 \%$ & $-23.71[-33.21,-14.21]$ \\
\hline \multicolumn{9}{|c|}{ Heterogeneity: $\operatorname{Tau}^{2}=42.8 \mathrm{I} ; \mathrm{Chi}^{2}=5.07, \mathrm{df}=2(\mathrm{P}=0.08) ; \mathrm{I}^{2}=61 \%$} \\
\hline \multicolumn{9}{|c|}{ Test for overall effect: $Z=4.89(P<0.0000 \mathrm{I})$} \\
\hline & & & & & -25 & 25 & 50 & \\
\hline \multicolumn{9}{|c|}{ Favours discectomy } \\
\hline
\end{tabular}

\section{Analysis I.3. Comparison I Discectomy alone vs human bone graft, Outcome 3 Blood loss.}

Review: Single or double-level anterior interbody fusion techniques for cervical degenerative disc disease

Comparison: I Discectomy alone vs human bone graft

Outcome: 3 Blood loss

\begin{tabular}{|c|c|c|c|c|c|c|c|}
\hline \multirow[t]{2}{*}{ Study or subgroup } & \multirow{2}{*}{$\begin{array}{r}\text { Discectomy } \\
\mathrm{N}\end{array}$} & \multicolumn{3}{|c|}{ Fusion } & \multirow{2}{*}{$\begin{array}{c}\text { Mean } \\
\text { Difference } \\
\text { IV,Random,95\% Cl }\end{array}$} & \multirow[t]{2}{*}{ Weight } & \multirow{2}{*}{$\begin{array}{r}\text { Mean } \\
\text { Difference } \\
\text { IV,Random,95\% Cl } \\
\end{array}$} \\
\hline & & Mean(SD) & N & Mean(SD) & & & \\
\hline Barlocher 2002 & 33 & $49.7(12.6)$ & 30 & $70.7(17.8)$ & + & $100.0 \%$ & $-21.00[-28.68,-13.32]$ \\
\hline Total $(95 \%$ CI $)$ & 33 & & 30 & & $\bullet$ & $100.0 \%$ & $-21.00[-28.68,-13.32]$ \\
\hline \multicolumn{8}{|c|}{ Heterogeneity: not applicable } \\
\hline \multicolumn{8}{|c|}{ Test for overall effect: $Z=5.36(P<0.0000 \mathrm{I})$} \\
\hline \multicolumn{8}{|c|}{ Test for subgroup differences: Not applicable } \\
\hline
\end{tabular}

$\begin{array}{lllll}-100 & -50 & 0 & 50 & 100\end{array}$


Analysis I.4. Comparison I Discectomy alone vs human bone graft, Outcome 4 Pain not relieved at 5 weeks.

Review: Single or double-level anterior interbody fusion techniques for cervical degenerative disc disease

Comparison: I Discectomy alone vs human bone graft

Outcome: 4 Pain not relieved at 5 weeks

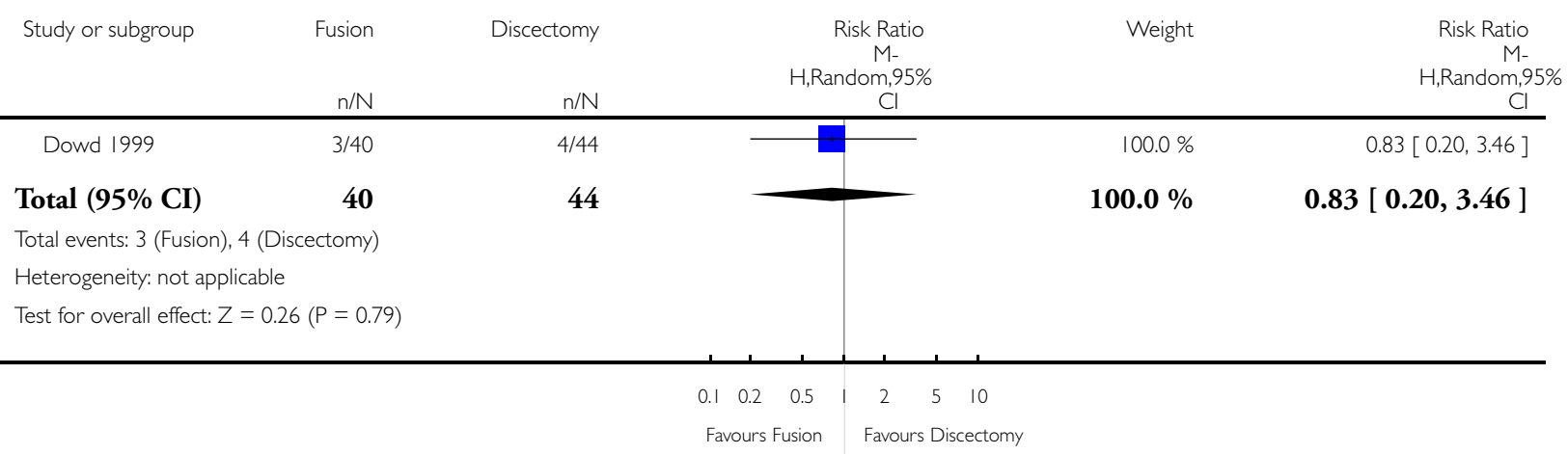

\section{Analysis I.5. Comparison I Discectomy alone vs human bone graft, Outcome 5 Odom's criteria.}

Review: Single or double-level anterior interbody fusion techniques for cervical degenerative disc disease

Comparison: I Discectomy alone vs human bone graft

Outcome: 5 Odom's criteria

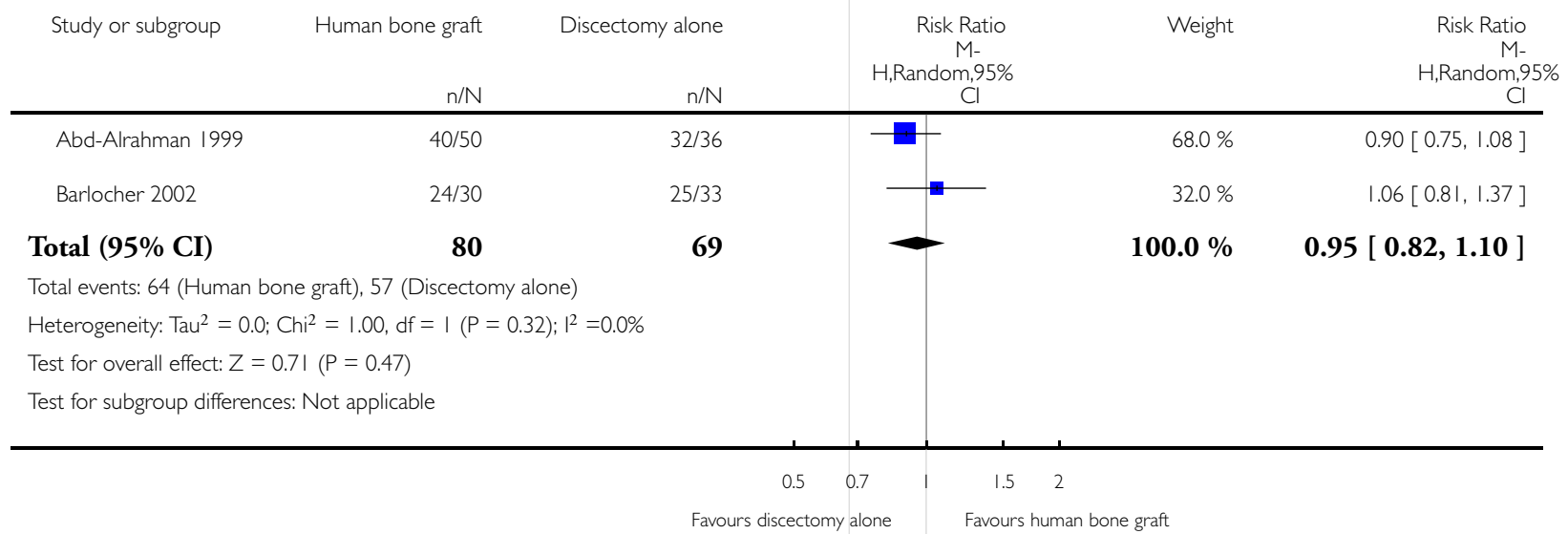


Analysis I.6. Comparison I Discectomy alone vs human bone graft, Outcome 6 Not Returned to work at 5 weeks.

Review: Single or double-level anterior interbody fusion techniques for cervical degenerative disc disease

Comparison: I Discectomy alone vs human bone graft

Outcome: 6 Not Returned to work at 5 weeks

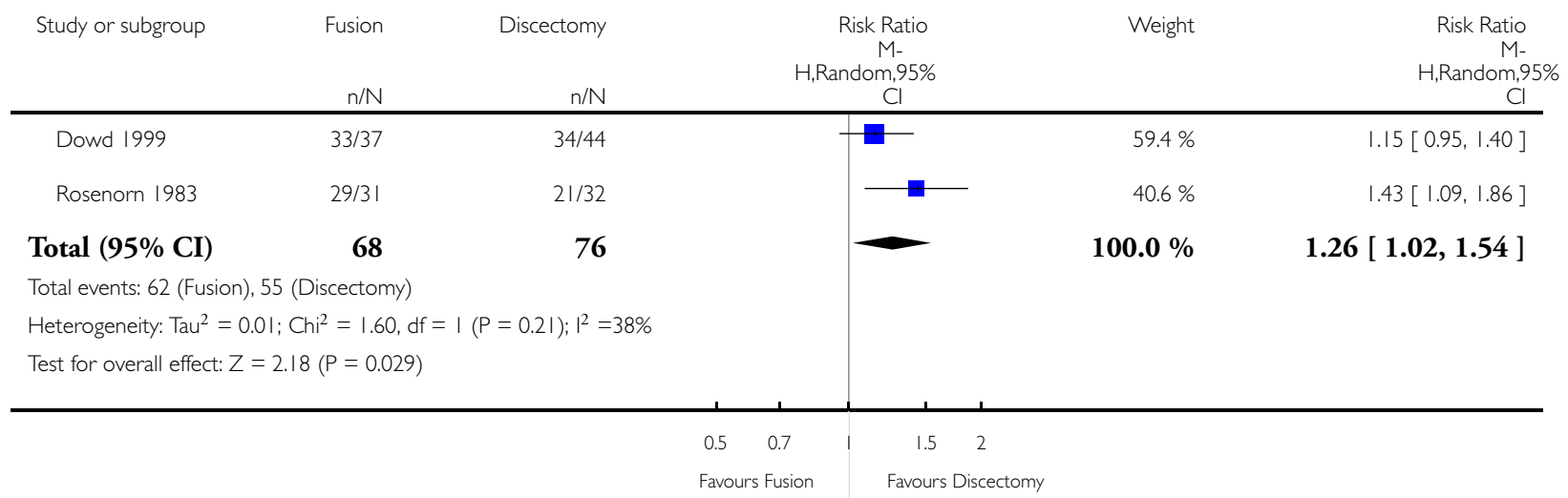

\section{Analysis I.7. Comparison I Discectomy alone vs human bone graft, Outcome 7 Not Returned to work at 10} weeks.

Review: Single or double-level anterior interbody fusion techniques for cervical degenerative disc disease

Comparison: I Discectomy alone vs human bone graft

Outcome: 7 Not Returned to work at 10 weeks

\begin{tabular}{|c|c|c|c|c|c|}
\hline Study or subgroup & $\begin{array}{r}\text { Fusion } \\
\mathrm{n} / \mathrm{N}\end{array}$ & $\begin{array}{r}\text { Discectomy } \\
n / N\end{array}$ & $\begin{array}{r}\text { Risk Ratio } \\
\text { M- } \\
\text { H,Random,95\% } \\
\mathrm{Cl}\end{array}$ & Weight & $\begin{array}{c}\text { Risk Ratio } \\
\text { M- } \\
\text { H,Random,95\% } \\
\mathrm{Cl}\end{array}$ \\
\hline Dowd 1999 & $23 / 33$ & 20/32 & + & $58.5 \%$ & $1.12[0.79,1.58]$ \\
\hline Rosenorn 1983 & $|8 / 3|$ & $9 / 32$ & 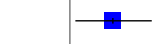 & $41.5 \%$ & $2.06[1.10,3.87]$ \\
\hline Total $(95 \% \mathrm{CI})$ & 64 & 64 & 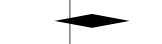 & $100.0 \%$ & $1.44[0.77,2.69]$ \\
\hline \multicolumn{6}{|c|}{ Total events: 4I (Fusion), 29 (Discectomy) } \\
\hline \multicolumn{6}{|c|}{ Heterogeneity: $\operatorname{Tau}^{2}=0.14 ; \mathrm{Chi}^{2}=3.10, \mathrm{df}=1(P=0.08) ; \mathrm{I}^{2}=68 \%$} \\
\hline \multicolumn{6}{|c|}{ Test for overall effect: $Z=1.14(P=0.25)$} \\
\hline
\end{tabular}




\section{Analysis I.8. Comparison I Discectomy alone vs human bone graft, Outcome 8 No Fusion.}

Review: Single or double-level anterior interbody fusion techniques for cervical degenerative disc disease

Comparison: I Discectomy alone vs human bone graft

Outcome: 8 No Fusion

\begin{tabular}{|c|c|c|c|c|c|}
\hline Study or subgroup & $\begin{array}{r}\text { Fusion } \\
\mathrm{n} / \mathrm{N} \\
\end{array}$ & discectomy & $\begin{array}{c}\text { Risk Ratio } \\
\text { M- } \\
\text { H,Random,95\% } \\
\text { Cl } \\
\end{array}$ & Weight & $\begin{array}{c}\text { Risk Ratio } \\
\text { M- } \\
\text { H,Random,95\% } \\
\text { Cl }\end{array}$ \\
\hline Abd-Alrahman 1999 (I) & $3 / 50$ & $14 / 40$ & & $45.1 \%$ & $0.17[0.05,0.56]$ \\
\hline Barlocher 2002 & 2/30 & $2 / 33$ & & $17.3 \%$ & $1.10[0.17,7.33]$ \\
\hline Dowd 1999 (2) & $|/ 3|$ & $9 / 31$ & & $15.5 \%$ & $0.11[0.01,0.83]$ \\
\hline Savolainen 1998 (3) & $0 / 30$ & $3 / 31$ & & $7.3 \%$ & $0.15[0.01,2.74]$ \\
\hline Xie 2007 (4) & $1 / 15$ & $4 / 12$ & - & $14.8 \%$ & $0.20[0.03,1.56]$ \\
\hline Total (95\% CI) & 156 & 147 & & $100.0 \%$ & $0.22[0.10,0.49]$ \\
\hline \multicolumn{6}{|c|}{ Total events: 7 (Fusion), 32 (discectomy) } \\
\hline \multicolumn{6}{|c|}{ Heterogeneity: $\operatorname{Tau}^{2}=0.0 ; \mathrm{Chi}^{2}=3.49, \mathrm{df}=4(\mathrm{P}=0.48) ; \mathrm{I}^{2}=0.0 \%$} \\
\hline \multicolumn{6}{|c|}{ Test for overall effect: $Z=3.72(P=0.00020)$} \\
\hline
\end{tabular}

$\begin{array}{lllll}0.01 & 0.1 & 1 & 10 & 100\end{array}$

Favours Fusion Favours Discectomy
(1) 2 years
(2) 3 years
(3) 6 months
(4) 2 years 


\section{Analysis 1.9. Comparison I Discectomy alone vs human bone graft, Outcome 9 Alignment.}

Review: Single or double-level anterior interbody fusion techniques for cervical degenerative disc disease

Comparison: I Discectomy alone vs human bone graft

Outcome: 9 Alignment

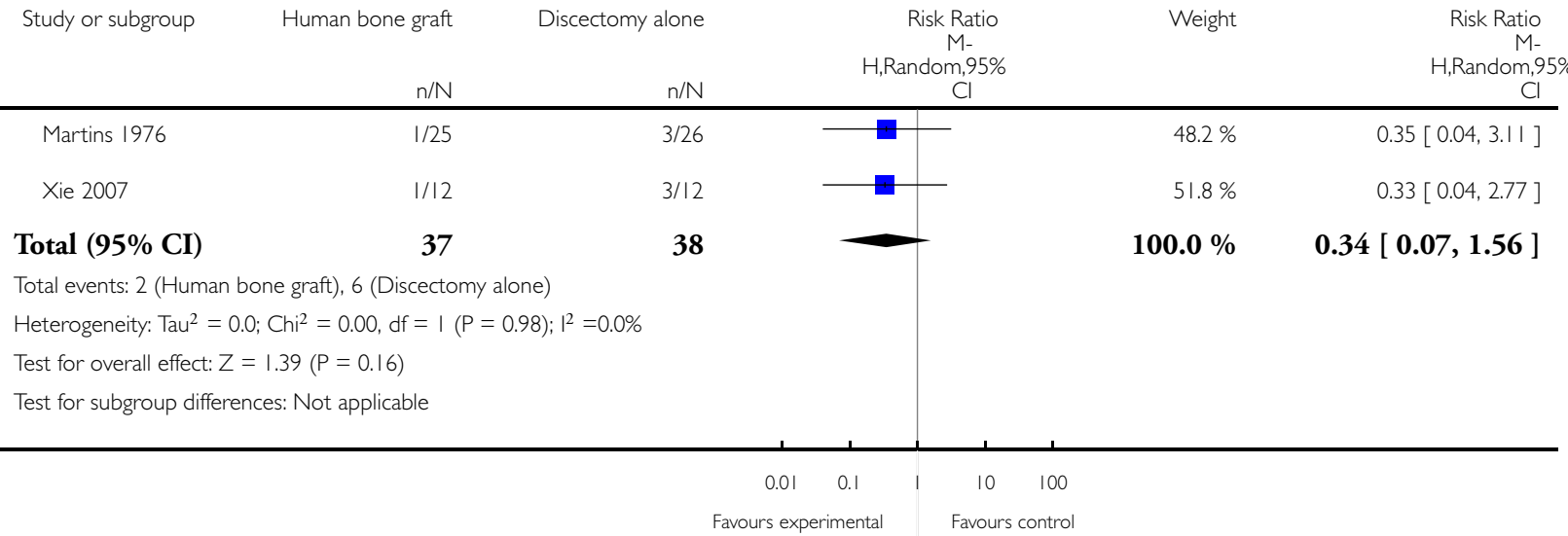

Analysis 2.1. Comparison 2 Discectomy alone vs cage or cement, Outcome I Operation time.

Review: Single or double-level anterior interbody fusion techniques for cervical degenerative disc disease

Comparison: 2 Discectomy alone vs cage or cement

Outcome: I Operation time

\begin{tabular}{|c|c|c|c|c|c|c|c|}
\hline \multirow[t]{2}{*}{ Study or subgroup } & Cage or cement & \multicolumn{3}{|c|}{ discectomy alone } & \multirow{2}{*}{$\begin{array}{c}\text { Mean } \\
\text { Difference } \\
\text { IV,Random,95\% Cl }\end{array}$} & \multirow[t]{2}{*}{ Weight } & \multirow{2}{*}{$\begin{array}{r}\text { Mean } \\
\text { Difference } \\
\text { IV,Random,95\% Cl }\end{array}$} \\
\hline & N & Mean(SD) & $\mathrm{N}$ & Mean(SD) & & & \\
\hline \multicolumn{8}{|l|}{ I Discectomy alone vs cage } \\
\hline Barlocher 2002 & 36 & $75.8(\mid 4.8)$ & 33 & $82.6(11.2)$ & \# & $24.9 \%$ & $-6.80[-12.96,-0.64]$ \\
\hline Hauerberg 2008 (I) & 40 & $60(15)$ & 46 & $55(15)$ & $\nexists$ & $24.8 \%$ & $5.00[-1.36,11.36]$ \\
\hline Ruetten 2009 (2) & 60 & $62(15)$ & 60 & $32(8)$ & $\boxplus$ & $25.3 \%$ & $30.00[25.70,34.30]$ \\
\hline Subtotal (95\% CI) & 136 & & 139 & & 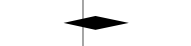 & $75.0 \%$ & $9.49[-13.66,32.64]$ \\
\hline \multicolumn{8}{|c|}{ Heterogeneity: Tau $^{2}=4 \mid 0.14 ; \mathrm{Chi}^{2}=104.29, \mathrm{df}=2(\mathrm{P}<0.0000 \mathrm{I}) ; \mathrm{I}^{2}=98 \%$} \\
\hline \multicolumn{8}{|c|}{ Test for overall effect: $Z=0.80(P=0.42)$} \\
\hline \multicolumn{8}{|c|}{2 Discectomy alone vs PMMA } \\
\hline Barlocher 2002 & 26 & $89(11.6)$ & 33 & $82.6(11.2)$ & 巴 & $25.0 \%$ & $6.40[0.53,12.27]$ \\
\hline Subtotal (95\% CI) & 26 & & 33 & & $\bullet$ & $25.0 \%$ & $6.40[0.53,12.27]$ \\
\hline (2) mean & & & & & & & (Continued....) \\
\hline
\end{tabular}

Copyright (C) 201 I The Cochrane Collaboration. Published by John Wiley \& Sons, Ltd. 


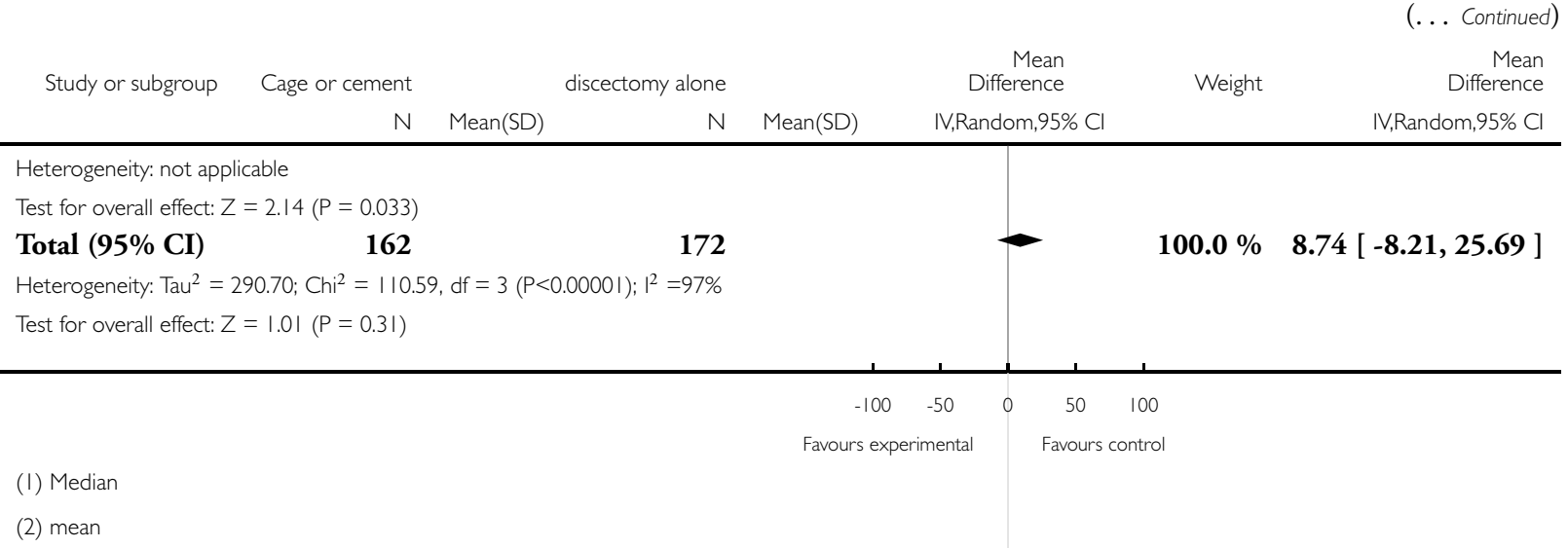

\section{Analysis 2.2. Comparison 2 Discectomy alone vs cage or cement, Outcome 2 Blood loss.}

Review: Single or double-level anterior interbody fusion techniques for cervical degenerative disc disease

Comparison: 2 Discectomy alone vs cage or cement

Outcome: 2 Blood loss

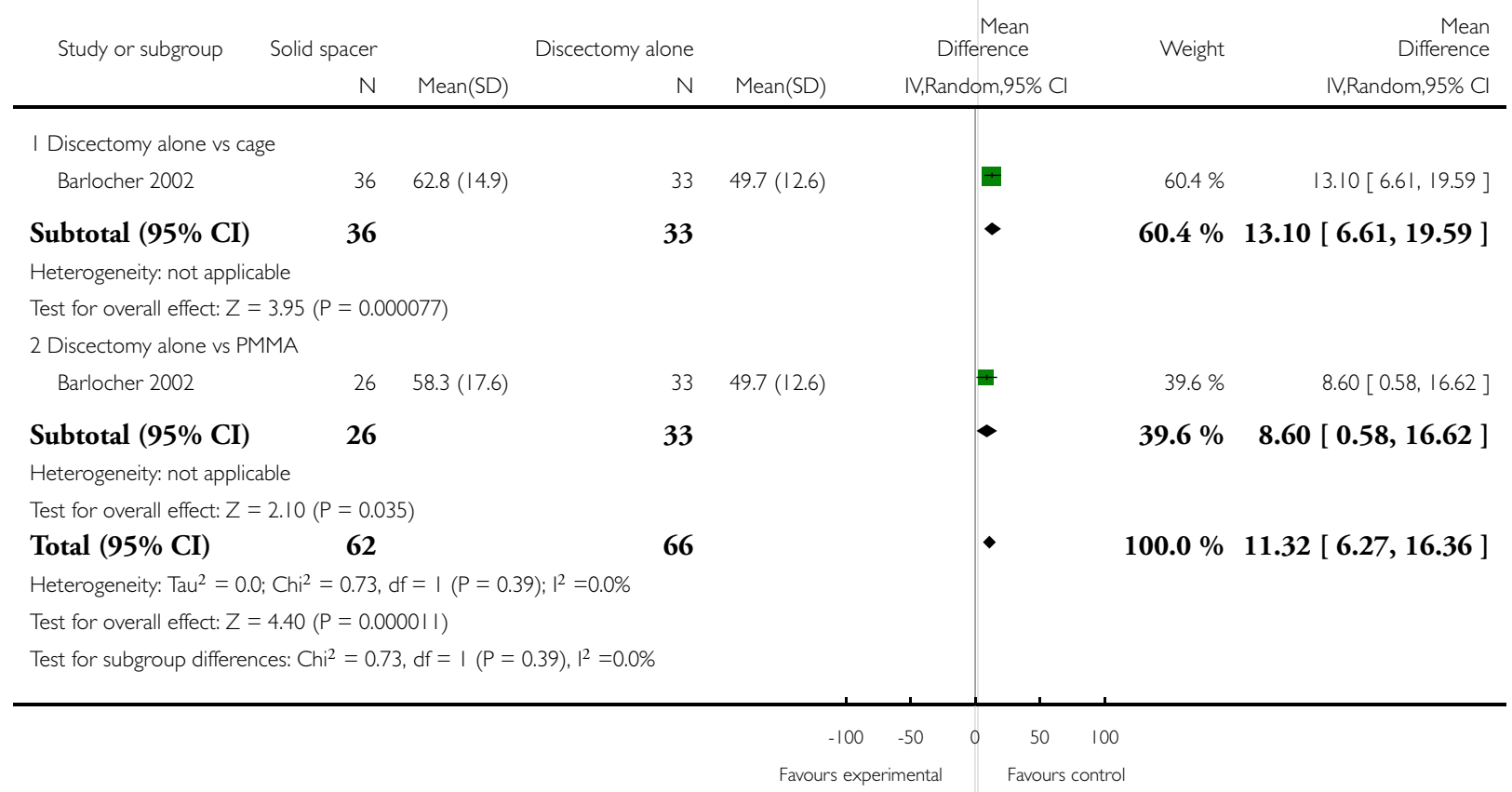




\section{Analysis 2.3. Comparison 2 Discectomy alone vs cage or cement, Outcome 3 Length of stay.}

Review: Single or double-level anterior interbody fusion techniques for cervical degenerative disc disease

Comparison: 2 Discectomy alone vs cage or cement

Outcome: 3 Length of stay

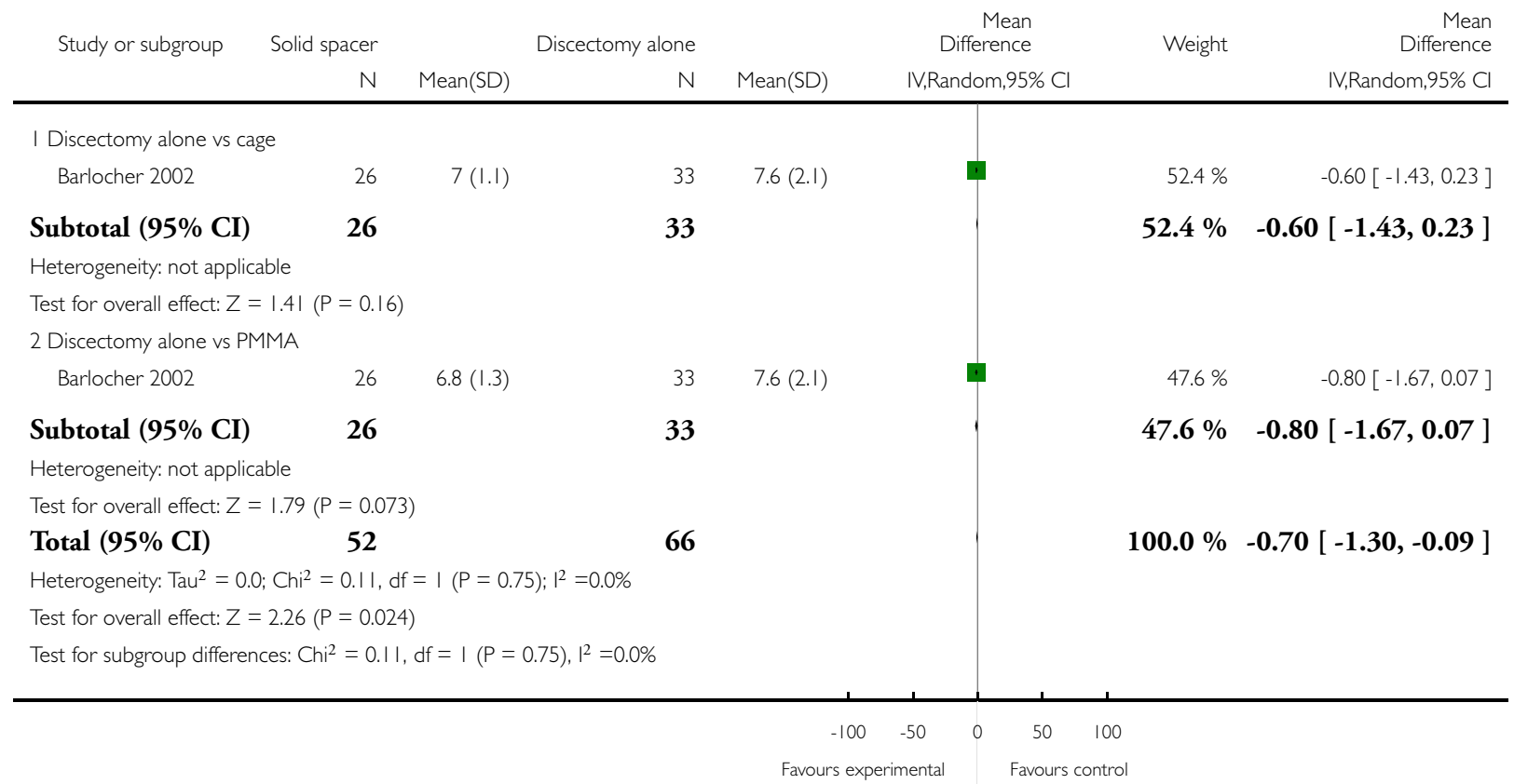




\section{Analysis 2.4. Comparison 2 Discectomy alone vs cage or cement, Outcome 4 Recovery.}

Review: Single or double-level anterior interbody fusion techniques for cervical degenerative disc disease

Comparison: 2 Discectomy alone vs cage or cement

Outcome: 4 Recovery

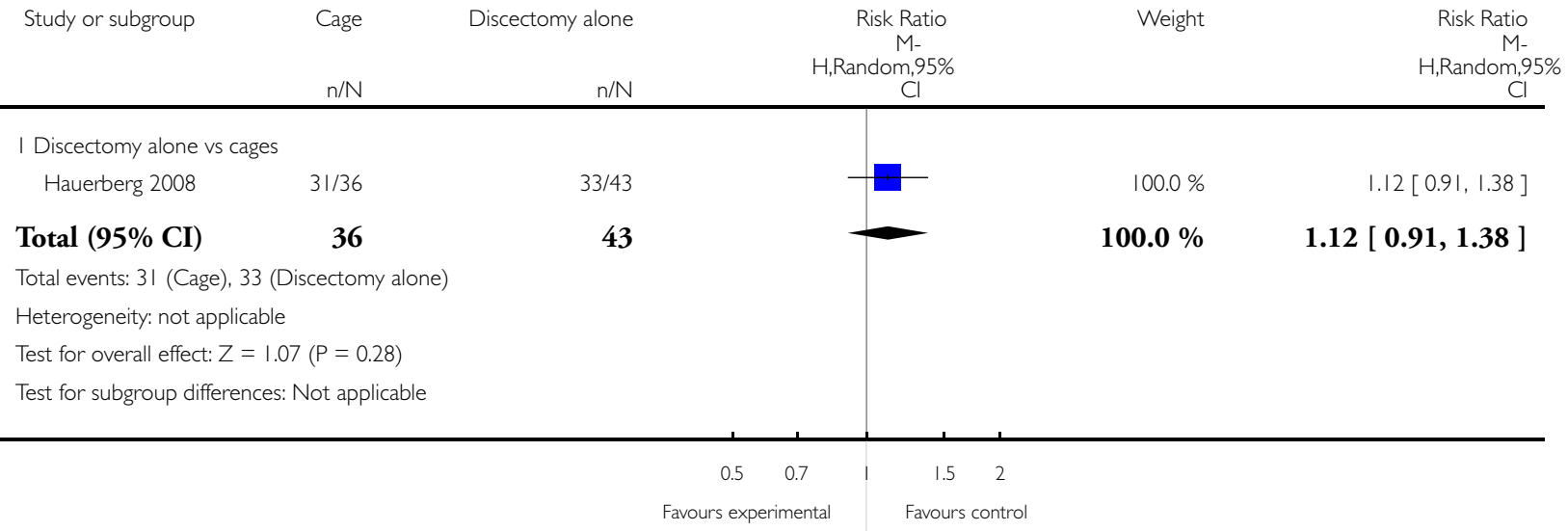

\section{Analysis 2.5. Comparison 2 Discectomy alone vs cage or cement, Outcome 5 Neck pain not relieved at 6} weeks.

Review: Single or double-level anterior interbody fusion techniques for cervical degenerative disc disease

Comparison: 2 Discectomy alone vs cage or cement

Outcome: 5 Neck pain not relieved at 6 weeks

\begin{tabular}{|c|c|c|c|c|c|}
\hline Study or subgroup & $\begin{array}{r}\text { Fusion } \\
n / N\end{array}$ & Discectomy & $\begin{array}{c}\text { Risk Ratio } \\
\text { M- } \\
\text { H,Random,95\% } \\
\mathrm{Cl}\end{array}$ & Weight & $\begin{array}{c}\text { Risk Ratio } \\
\text { M- } \\
\text { H,Random,95\% } \\
\text { Cl }\end{array}$ \\
\hline \multicolumn{6}{|c|}{ Discectomy alone vs cement } \\
\hline Barlocher 2002 (I) & $19 / 26$ & $18 / 33$ & 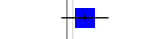 & $52.1 \%$ & $1.34[0.91,1.98]$ \\
\hline van den Bent 1996 & $9 / 42$ & $21 / 39$ & 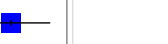 & $47.9 \%$ & $0.40[0.21,0.76]$ \\
\hline
\end{tabular}

Subtotal $(95 \% \mathrm{CI}) \quad 68$

72

$100.0 \%$

$0.75[0.21,2.66]$

Total events: 28 (Fusion), 39 (Discectomy)

Heterogeneity: $\mathrm{Tau}^{2}=0.77 ; \mathrm{Chi}^{2}=11.29, \mathrm{df}=1(\mathrm{P}=0.00078) ; \mathrm{I}^{2}=91 \%$

Test for overall effect: $Z=0.45(P=0.66)$

(I) 2 months

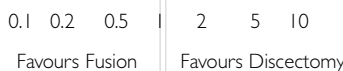


Analysis 2.6. Comparison 2 Discectomy alone vs cage or cement, Outcome 6 Neck pain not relieved at 2 years.

Review: Single or double-level anterior interbody fusion techniques for cervical degenerative disc disease

Comparison: 2 Discectomy alone vs cage or cement

Outcome: 6 Neck pain not relieved at 2 years

\begin{tabular}{|c|c|c|c|c|c|}
\hline Study or subgroup & $\begin{array}{r}\text { Fusion } \\
n / N\end{array}$ & Discectomy & $\begin{array}{c}\text { Risk Ratio } \\
\text { M- } \\
\text { H,Random,95\% } \\
\text { Cl }\end{array}$ & Weight & $\begin{array}{c}\text { Risk Ratio } \\
\text { M- } \\
\text { H,Random,95\% } \\
\text { Cl }\end{array}$ \\
\hline \multicolumn{6}{|c|}{ I Discectomy alone vs cement } \\
\hline Barlocher $2002(1)$ & $9 / 24$ & $12 / 33$ & & $38.9 \%$ & $1.03[0.52,2.05]$ \\
\hline van den Bent 1996 & $16 / 39$ & $15 / 39$ & & $61.1 \%$ & $1.07[0.62,1.84]$ \\
\hline Subtotal $(95 \%$ CI $)$ & 63 & 72 & & $100.0 \%$ & $1.05[0.69,1.61]$ \\
\hline \multicolumn{6}{|c|}{ Total events: 25 (Fusion), 27 (Discectomy) } \\
\hline \multicolumn{6}{|c|}{ Heterogeneity: $\mathrm{Tau}^{2}=0.0 ; \mathrm{Chi}^{2}=0.0 \mathrm{I}, \mathrm{df}=\mathrm{I}(\mathrm{P}=0.94) ; \mathrm{I}^{2}=0.0 \%$} \\
\hline \multicolumn{6}{|c|}{ Test for overall effect: $Z=0.24(P=0.8 I)$} \\
\hline
\end{tabular}

(I) 12 months

\section{Analysis 2.7. Comparison 2 Discectomy alone vs cage or cement, Outcome 7 VAS Arm pain 24 months.}

Review: Single or double-level anterior interbody fusion techniques for cervical degenerative disc disease

Comparison: 2 Discectomy alone vs cage or cement

Outcome: 7 VAS Arm pain 24 months

\begin{tabular}{|c|c|c|c|c|c|c|c|c|}
\hline \multirow[t]{2}{*}{ Study or subgroup } & \multirow{2}{*}{$\begin{array}{r}\text { Cage } \\
\mathrm{N}\end{array}$} & \multicolumn{3}{|c|}{ Discectomy alone } & \multicolumn{3}{|c|}{$\begin{array}{r}\text { Mean } \\
\text { Difference }\end{array}$} & \multirow{2}{*}{$\begin{array}{r}\text { Mean } \\
\text { Difference } \\
\text { IV,Random,95\% Cl }\end{array}$} \\
\hline & & Mean(SD) & $\mathrm{N}$ & Mean(SD) & \multicolumn{3}{|c|}{ IV,Random,95\% Cl } & \\
\hline \multicolumn{9}{|c|}{ I Discectomy alone versus cage } \\
\hline Ruetten 2009 & 49 & $10(0)$ & 54 & $8(0)$ & & & & $0.0[0.0,0.0]$ \\
\hline Total (95\% CI) & 49 & & 54 & & & & & $0.0[0.0,0.0]$ \\
\hline \multicolumn{9}{|c|}{ Heterogeneity: not applicable } \\
\hline \multicolumn{9}{|c|}{ Test for overall effect: $Z=0.0(P<0.0000 I)$} \\
\hline \multicolumn{9}{|c|}{ Test for subgroup differences: $\mathrm{Chi}^{2}=0.0, \mathrm{df}=-\mathrm{I}(\mathrm{P}=0.0), \mathrm{I}^{2}=0.0 \%$} \\
\hline
\end{tabular}


Analysis 2.8. Comparison 2 Discectomy alone vs cage or cement, Outcome 8 VAS Neck pain 24 months.

Review: Single or double-level anterior interbody fusion techniques for cervical degenerative disc disease

Comparison: 2 Discectomy alone vs cage or cement

Outcome: 8 VAS Neck pain 24 months

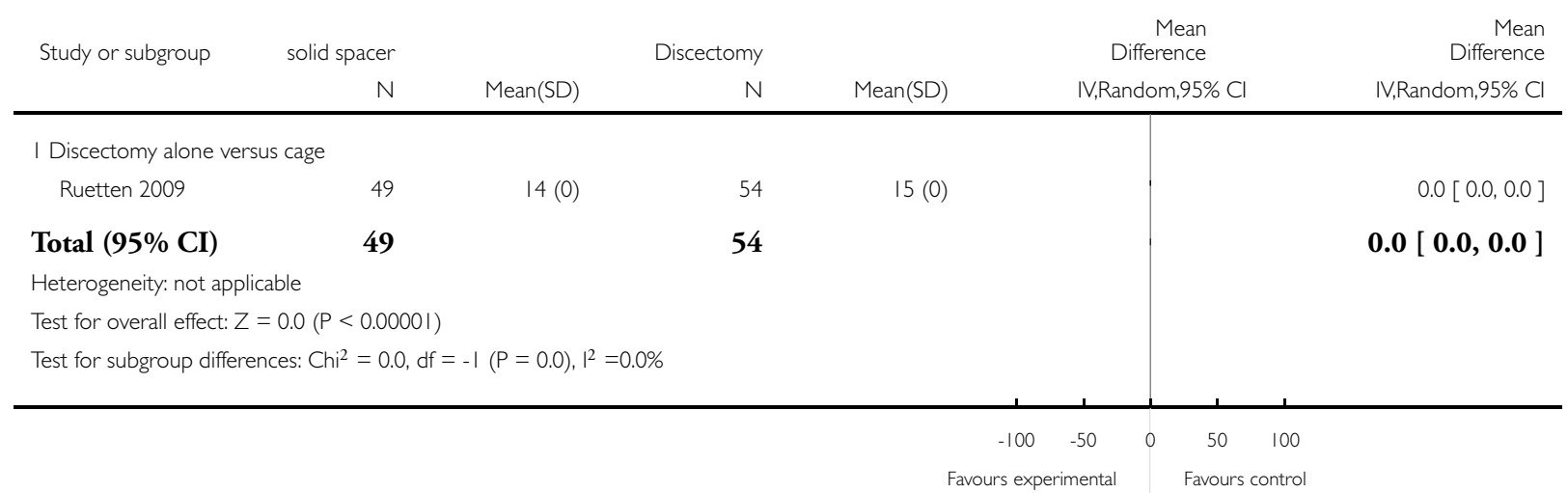

\section{Analysis 2.9. Comparison 2 Discectomy alone vs cage or cement, Outcome 9 NASS pain 24 months.}

Review: Single or double-level anterior interbody fusion techniques for cervical degenerative disc disease

Comparison: 2 Discectomy alone vs cage or cement

Outcome: 9 NASS pain 24 months

\begin{tabular}{|c|c|c|c|c|c|c|c|c|}
\hline \multirow[t]{2}{*}{ Study or subgroup } & \multirow{2}{*}{$\begin{array}{r}\text { Solid spacer } \\
\mathrm{N}\end{array}$} & \multicolumn{3}{|c|}{ discectomy alone } & \multicolumn{3}{|c|}{$\begin{array}{r}\text { Mean } \\
\text { Difference }\end{array}$} & \multirow{2}{*}{$\begin{array}{r}\text { Mean } \\
\text { Difference } \\
\text { IV,Random,95\% Cl }\end{array}$} \\
\hline & & Mean(SD) & $\mathrm{N}$ & Mean(SD) & & & dom,95\% Cl & \\
\hline \multicolumn{9}{|c|}{ I Discectomy alone vs cage } \\
\hline Ruetten 2009 & 49 & $1.6(0)$ & 54 & $1.5(0)$ & & & & $0.0[0.0,0.0]$ \\
\hline Total $(95 \% \mathrm{CI})$ & 49 & & 54 & & & & & $0.0[0.0,0.0]$ \\
\hline \multicolumn{9}{|c|}{ Heterogeneity: not applicable } \\
\hline \multicolumn{9}{|c|}{ Test for overall effect: $Z=0.0(P<0.0000 I)$} \\
\hline \multicolumn{9}{|c|}{ Test for subgroup differences: $\mathrm{Chi}^{2}=0.0, \mathrm{df}=-\mathrm{I}(\mathrm{P}=0.0), \mathrm{I}^{2}=0.0 \%$} \\
\hline
\end{tabular}


Analysis 2.10. Comparison 2 Discectomy alone vs cage or cement, Outcome 10 NASS neurology 24 months. Review: Single or double-level anterior interbody fusion techniques for cervical degenerative disc disease

Comparison: 2 Discectomy alone vs cage or cement

Outcome: 10 NASS neurology 24 months

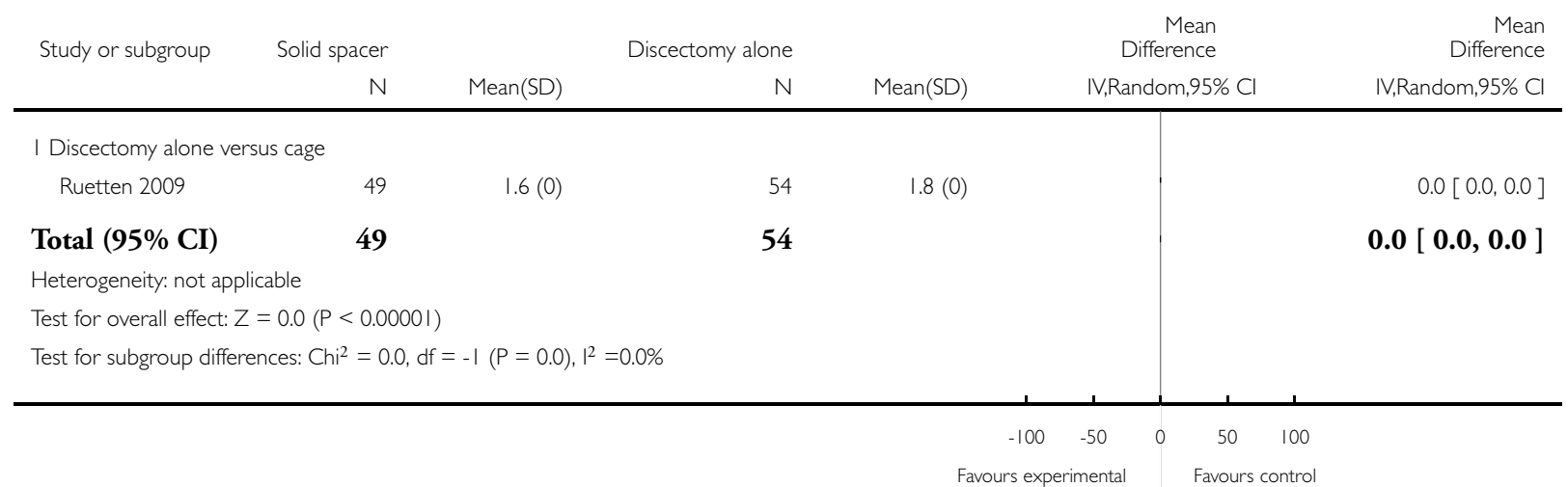

\section{Analysis 2.I I. Comparison 2 Discectomy alone vs cage or cement, Outcome I I No Fusion.}

Review: Single or double-level anterior interbody fusion techniques for cervical degenerative disc disease

Comparison: 2 Discectomy alone vs cage or cement

Outcome: II No Fusion

\begin{tabular}{|c|c|c|c|c|c|}
\hline Study or subgroup & $\begin{array}{l}\text { Fusion } \\
\mathrm{n} / \mathrm{N}\end{array}$ & discectomy & $\begin{array}{c}\text { Risk Ratio } \\
\text { M- } \\
\text { H,Random,95\% } \\
\text { Cl }\end{array}$ & Weight & $\begin{array}{c}\text { Risk Ratio } \\
\text { M- } \\
\text { H,Random,95\% } \\
\mathrm{Cl}\end{array}$ \\
\hline \multicolumn{6}{|c|}{ I Discectomy alone vs cement } \\
\hline Barlocher $2002(1)$ & $24 / 24$ & $2 / 33$ & 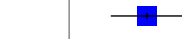 & $46.6 \%$ & $13.33[4.04,44.01]$ \\
\hline van den Bent 1996 (2) & $28 / 39$ & $13 / 35$ & + & $53.4 \%$ & $1.93[1.20,3.10]$ \\
\hline Subtotal (95\% CI) & 63 & 68 & & $100.0 \%$ & $4.75[0.58,38.67]$ \\
\hline \multicolumn{6}{|c|}{ Total events: 52 (Fusion), 15 (discectomy) } \\
\hline \multicolumn{6}{|c|}{ Heterogeneity: $\mathrm{Tau}^{2}=2.08 ; \mathrm{Chi}^{2}=10.69, \mathrm{df}=\mathrm{I}(\mathrm{P}=0.00 \mathrm{I}) ; \mathrm{I}^{2}=91 \%$} \\
\hline \multicolumn{6}{|c|}{ Test for overall effect: $Z=1.46(P=0.15)$} \\
\hline \multicolumn{6}{|l|}{2 Discectomy alone vs cage } \\
\hline Barlocher 2002 (3) & $1 / 36$ & $2 / 33$ & $\longrightarrow$ & $25.2 \%$ & $0.46[0.04,4.82]$ \\
\hline Hauerberg 2008 (4) & $3 / 36$ & $7 / 42$ & $\rightarrow$ & $34.3 \%$ & $0.50[0.14,1.79]$ \\
\hline Ruetten 2009 (5) & $49 / 49$ & $54 / 54$ & 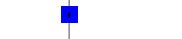 & $40.5 \%$ & $1.00[0.96,1.04]$ \\
\hline \multicolumn{6}{|l|}{ (5) 121 months } \\
\hline
\end{tabular}

Copyright $\odot 20$ II The Cochrane Collaboration. Published by John Wiley \& Sons, Ltd. 


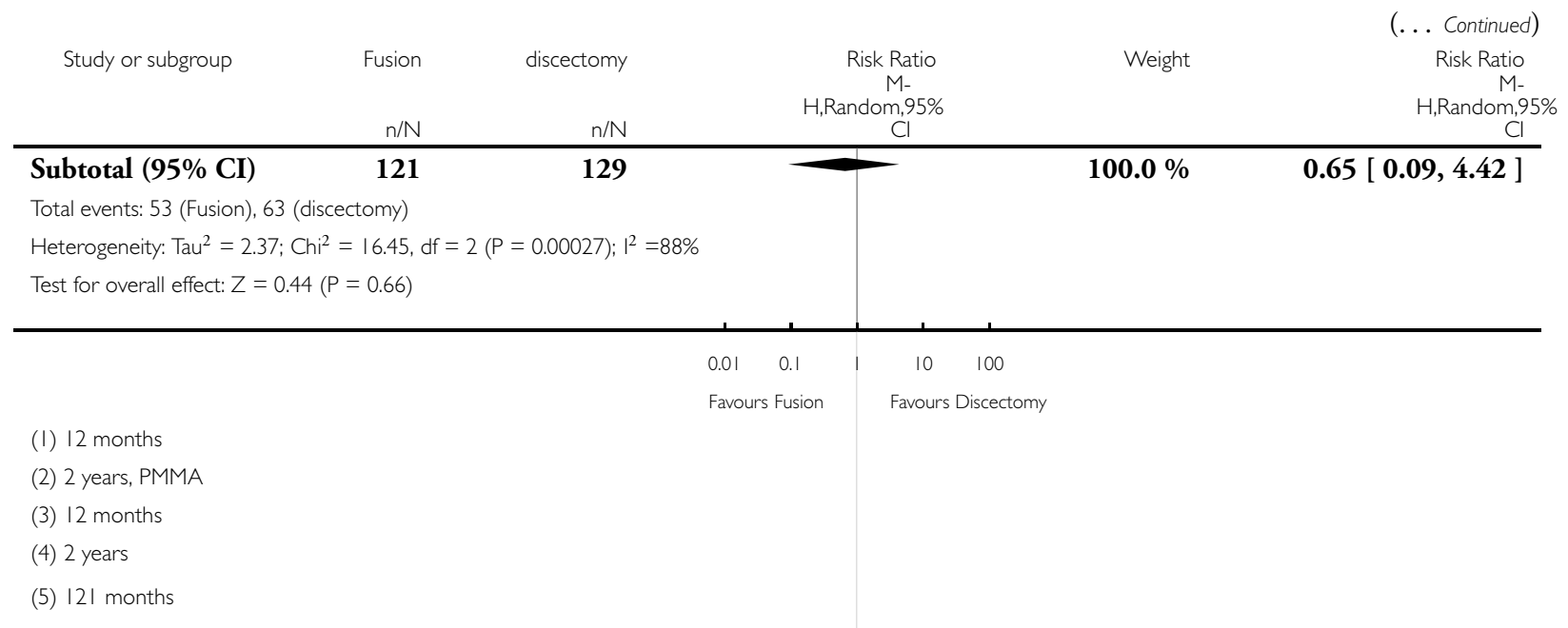

Analysis 2.12. Comparison 2 Discectomy alone vs cage or cement, Outcome 12 Odom's criteria.

Odom's criteria

\begin{tabular}{|c|c|c|c|c|c|}
\hline Study & Group & Excellent & Good & Fair & Poor \\
\hline \multicolumn{6}{|c|}{ Discectomy alone vs cage } \\
\hline Barlocher 2002 & Discectomy & 25 & & & 8 \\
\hline Barlocher 2002 & Cage & 34 & & & 2 \\
\hline \multicolumn{6}{|c|}{ Discectomy alone vs PMMA } \\
\hline Barlocher 2002 & Discectomy & 25 & & & 8 \\
\hline Barlocher 2002 & PMMA & 21 & & & 3 \\
\hline
\end{tabular}


Analysis 3.I. Comparison 3 Discectomy alone vs human bone graft with plates, Outcome I VAS Arm pain. Review: Single or double-level anterior interbody fusion techniques for cervical degenerative disc disease

Comparison: 3 Discectomy alone vs human bone graft with plates

Outcome: I VAS Arm pain

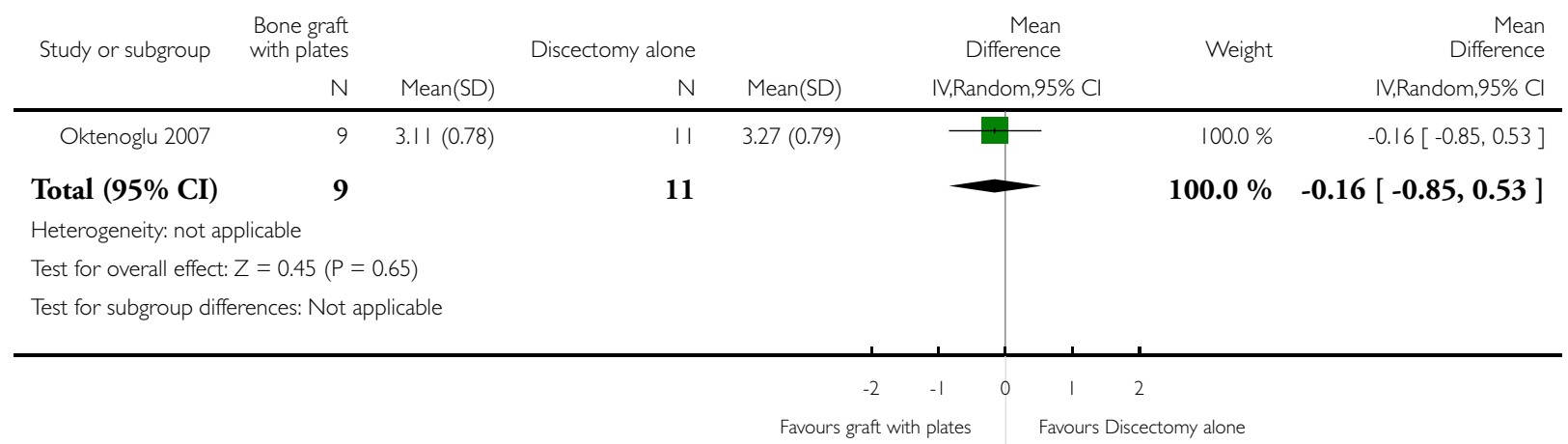

Analysis 3.2. Comparison 3 Discectomy alone vs human bone graft with plates, Outcome 2 VAS neck pain.

Review: Single or double-level anterior interbody fusion techniques for cervical degenerative disc disease

Comparison: 3 Discectomy alone vs human bone graft with plates

Outcome: 2 VAS neck pain

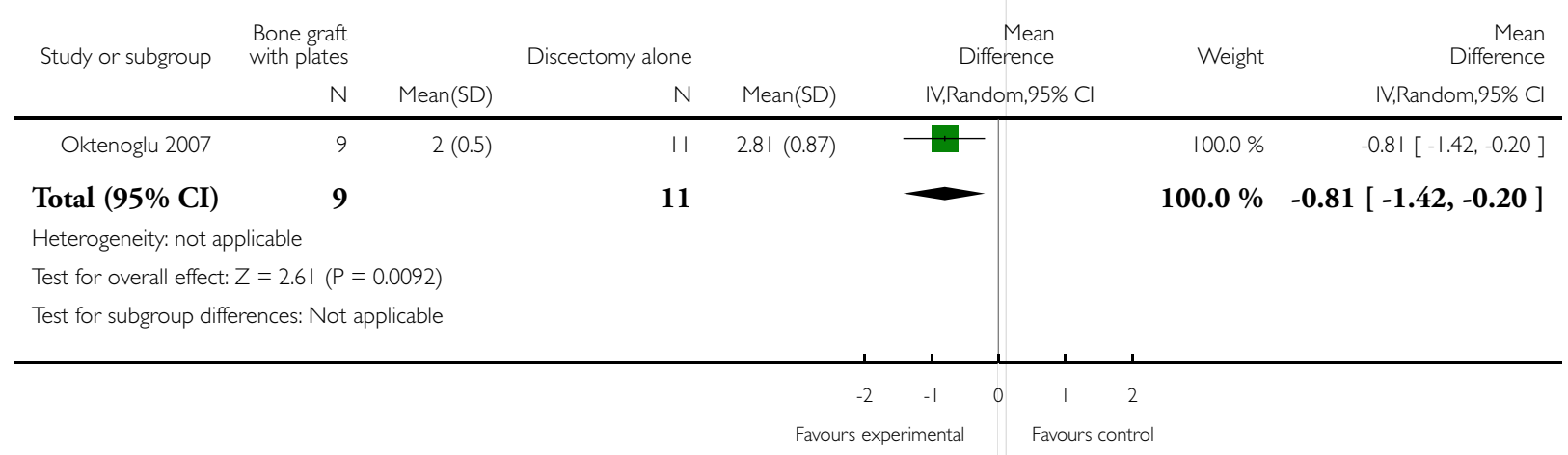


Analysis 3.3. Comparison 3 Discectomy alone vs human bone graft with plates, Outcome 3 Disc height.

Review: Single or double-level anterior interbody fusion techniques for cervical degenerative disc disease

Comparison: 3 Discectomy alone vs human bone graft with plates

Outcome: 3 Disc height

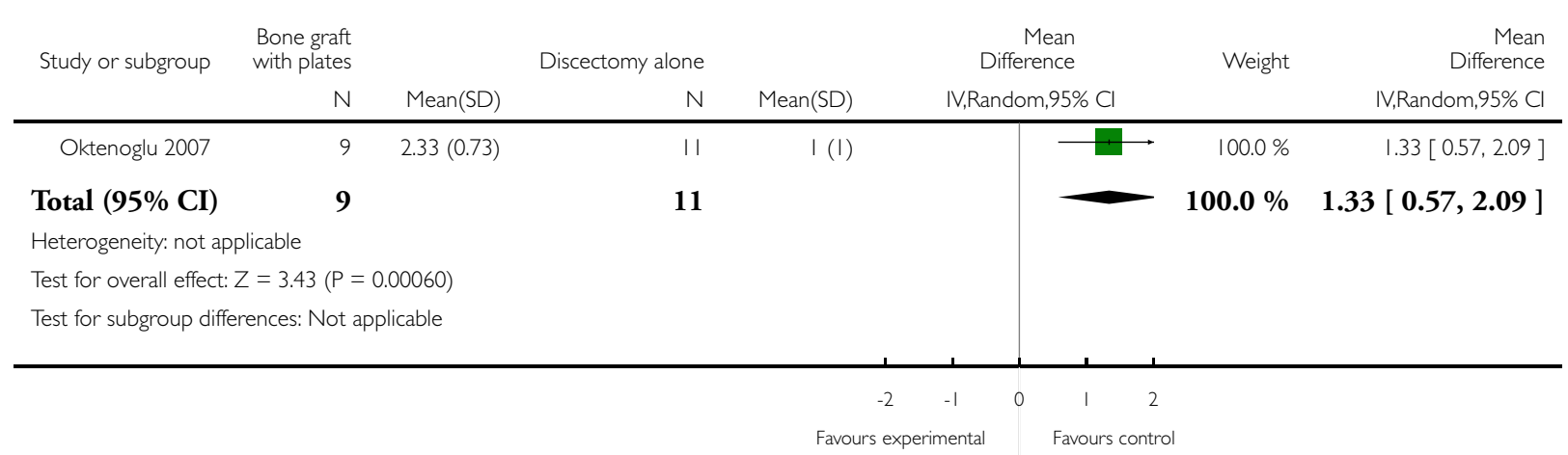

Analysis 3.4. Comparison 3 Discectomy alone vs human bone graft with plates, Outcome 4 Odoms criteria.

Review: Single or double-level anterior interbody fusion techniques for cervical degenerative disc disease

Comparison: 3 Discectomy alone vs human bone graft with plates

Outcome: 4 Odoms criteria

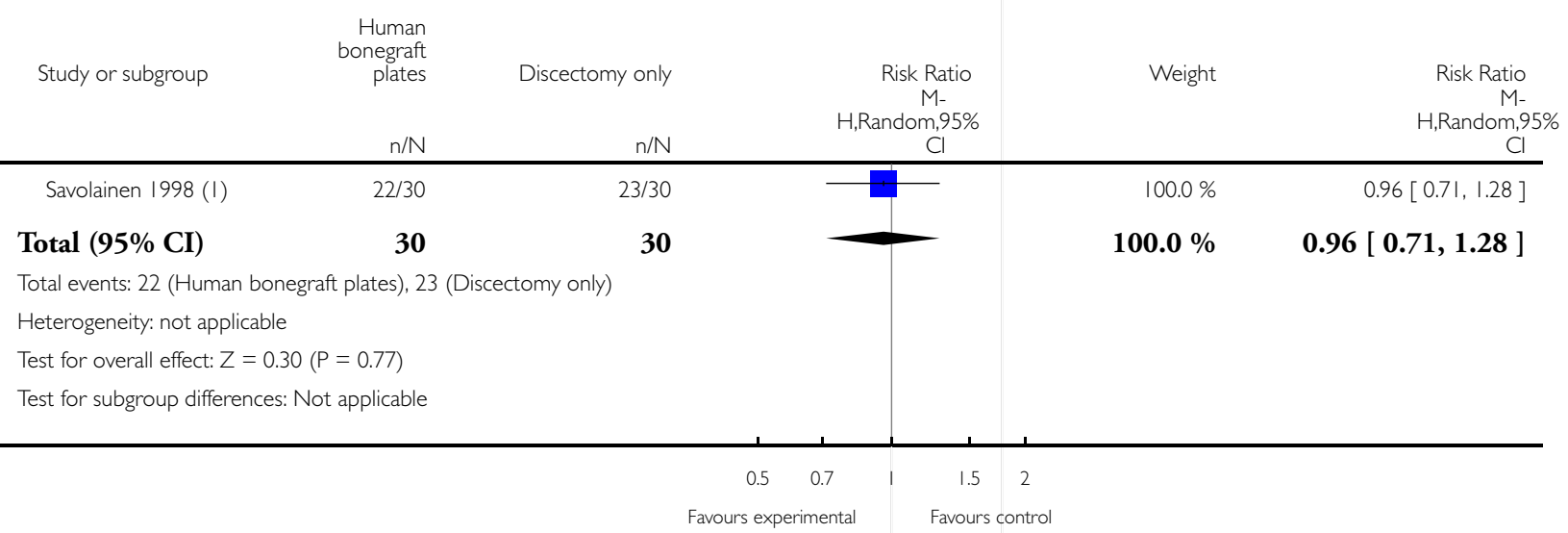

(1) 4 years 
Analysis 3.5. Comparison 3 Discectomy alone vs human bone graft with plates, Outcome 5 Fusion.

Review: Single or double-level anterior interbody fusion techniques for cervical degenerative disc disease

Comparison: 3 Discectomy alone vs human bone graft with plates

Outcome: 5 Fusion

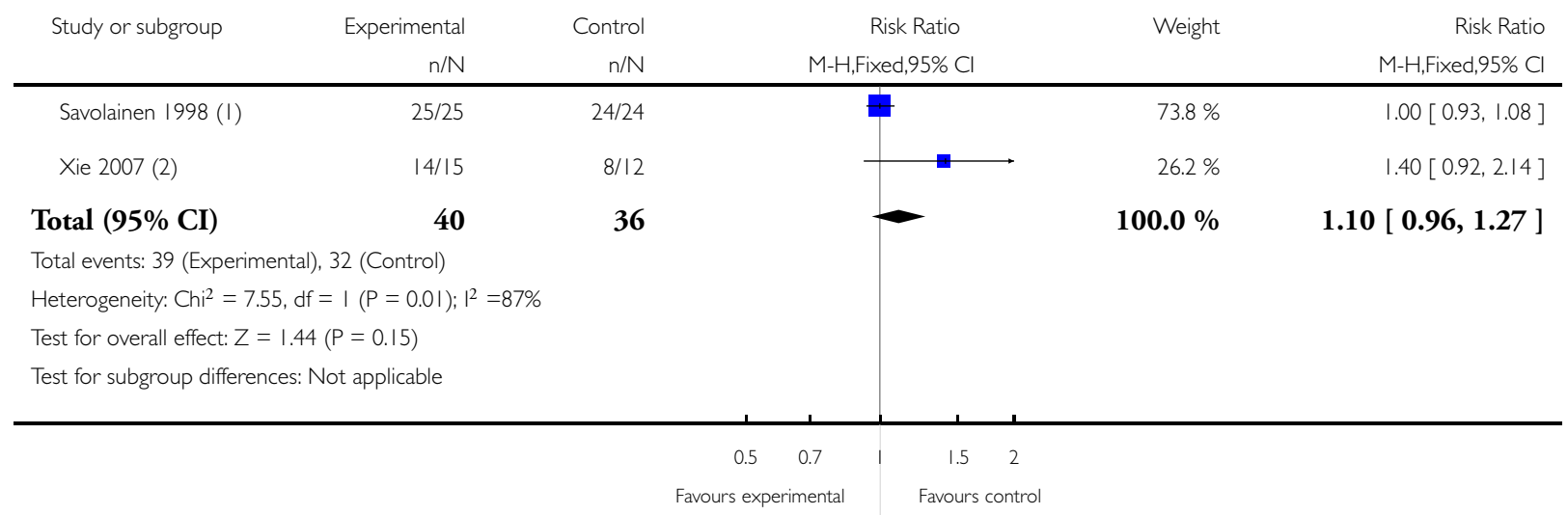

(1) 4 years

(2) 24 months

Analysis 4.I. Comparison 4 Iliac crest autograft vs human allograft or bone substitute, Outcome I headache.

Review: Single or double-level anterior interbody fusion techniques for cervical degenerative disc disease

Comparison: 4 lliac crest autograft vs human allograft or bone substitute

Outcome: I headache

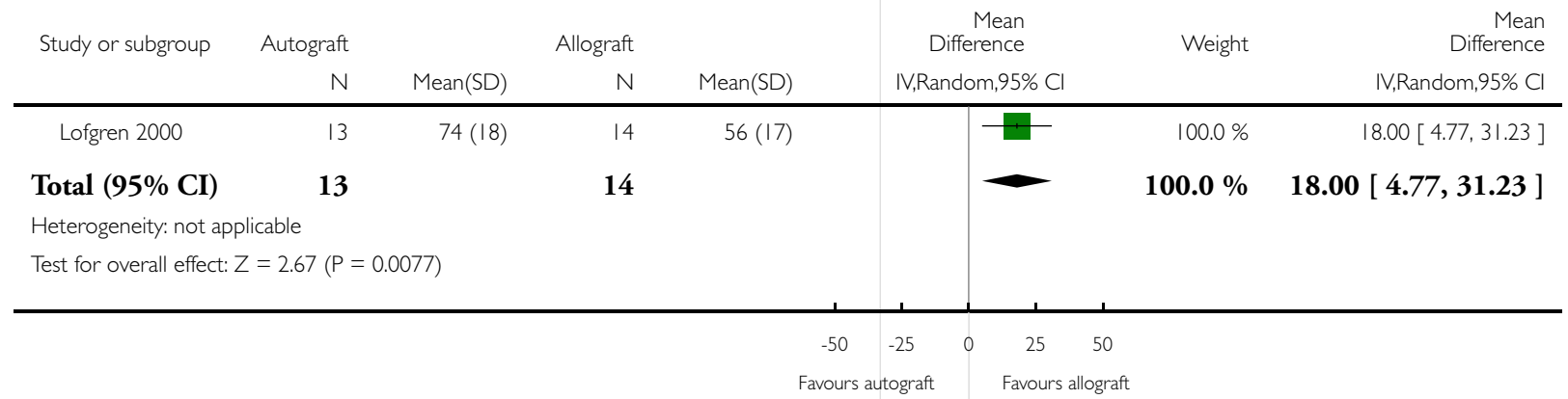


Analysis 4.2. Comparison 4 Iliac crest autograft vs human allograft or bone substitute, Outcome 2 Sensory function.

Review: Single or double-level anterior interbody fusion techniques for cervical degenerative disc disease

Comparison: 4 lliac crest autograft vs human allograft or bone substitute

Outcome: 2 Sensory function

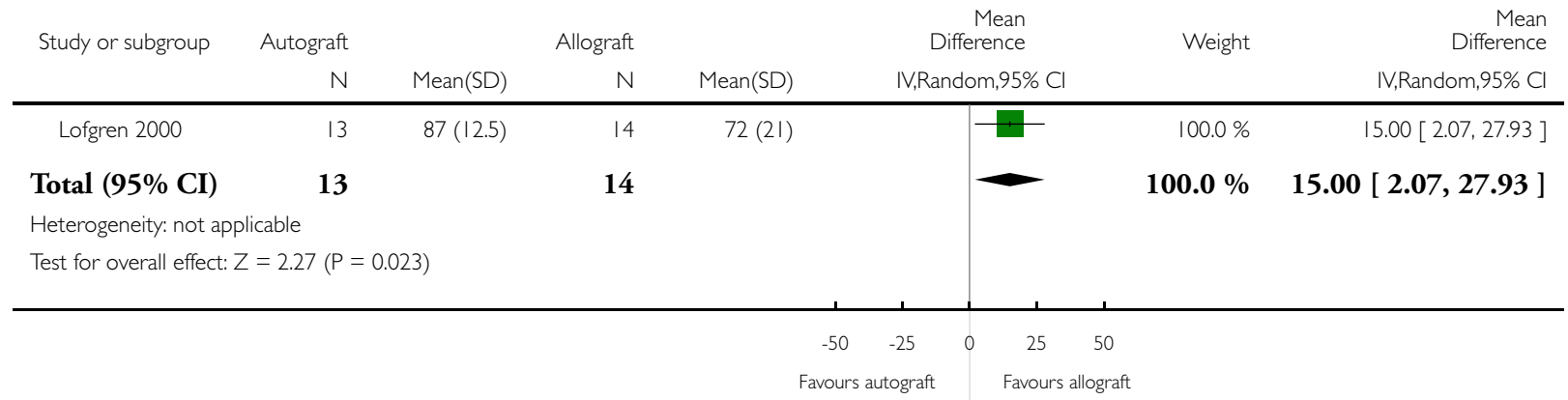

Analysis 4.3. Comparison 4 Iliac crest autograft vs human allograft or bone substitute, Outcome 3 Muscle power.

Review: Single or double-level anterior interbody fusion techniques for cervical degenerative disc disease

Comparison: 4 lliac crest autograft vs human allograft or bone substitute

Outcome: 3 Muscle power

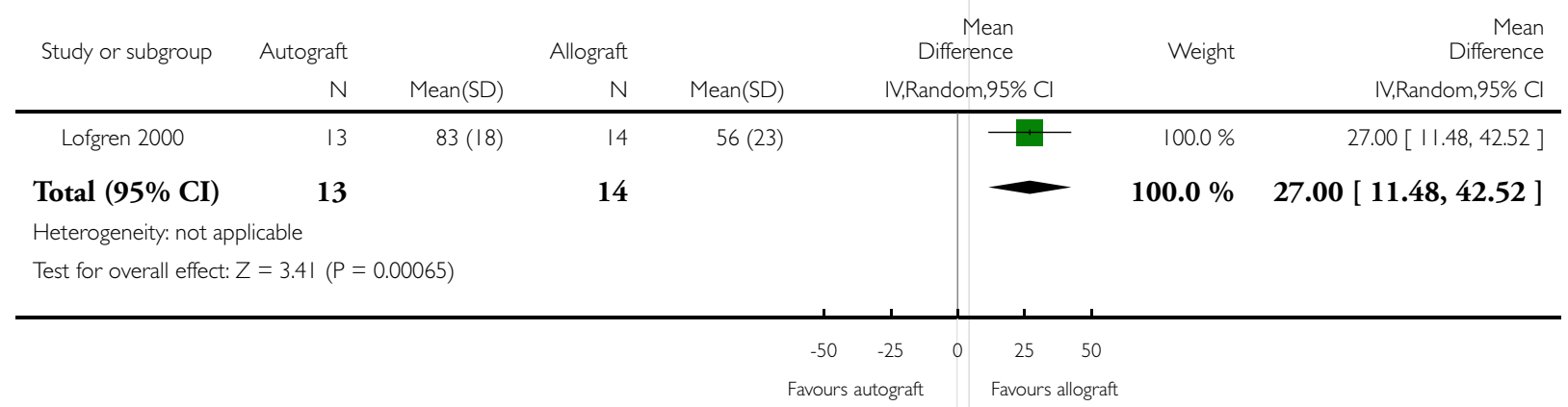


Analysis 4.4. Comparison 4 lliac crest autograft vs human allograft or bone substitute, Outcome 4 Odoms criteria.

Review: Single or double-level anterior interbody fusion techniques for cervical degenerative disc disease

Comparison: 4 lliac crest autograft vs human allograft or bone substitute

Outcome: 4 Odoms criteria

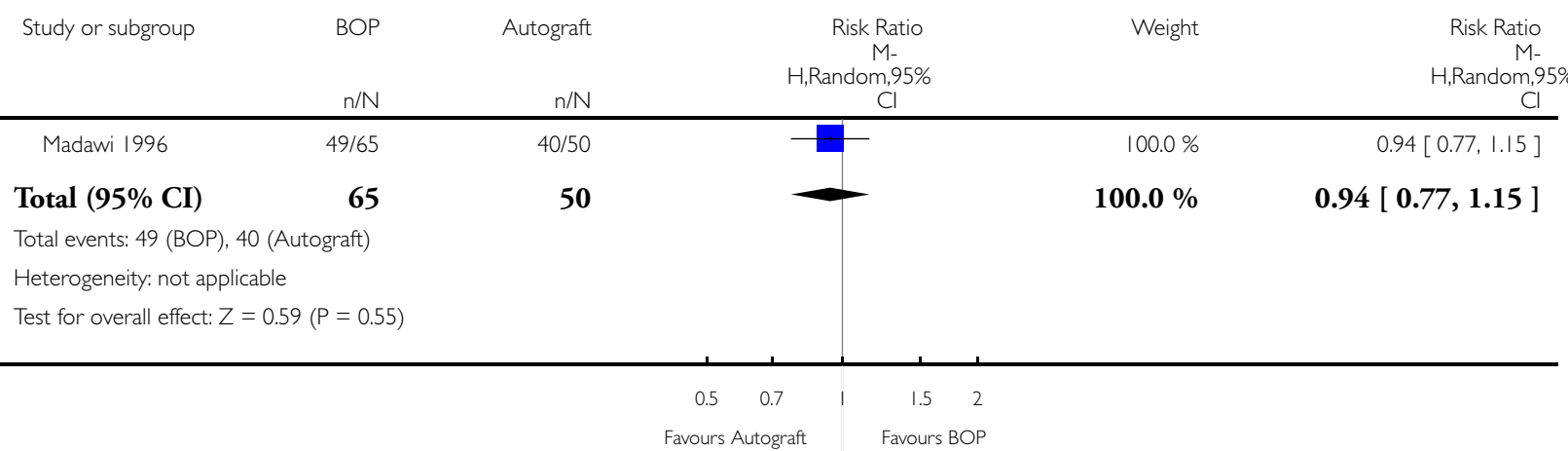

Analysis 5.I. Comparison 5 Iliac crest autograft vs cage, Outcome I Operation time.

Review: Single or double-level anterior interbody fusion techniques for cervical degenerative disc disease

Comparison: 5 lliac crest autograft vs cage

Outcome: I Operation time

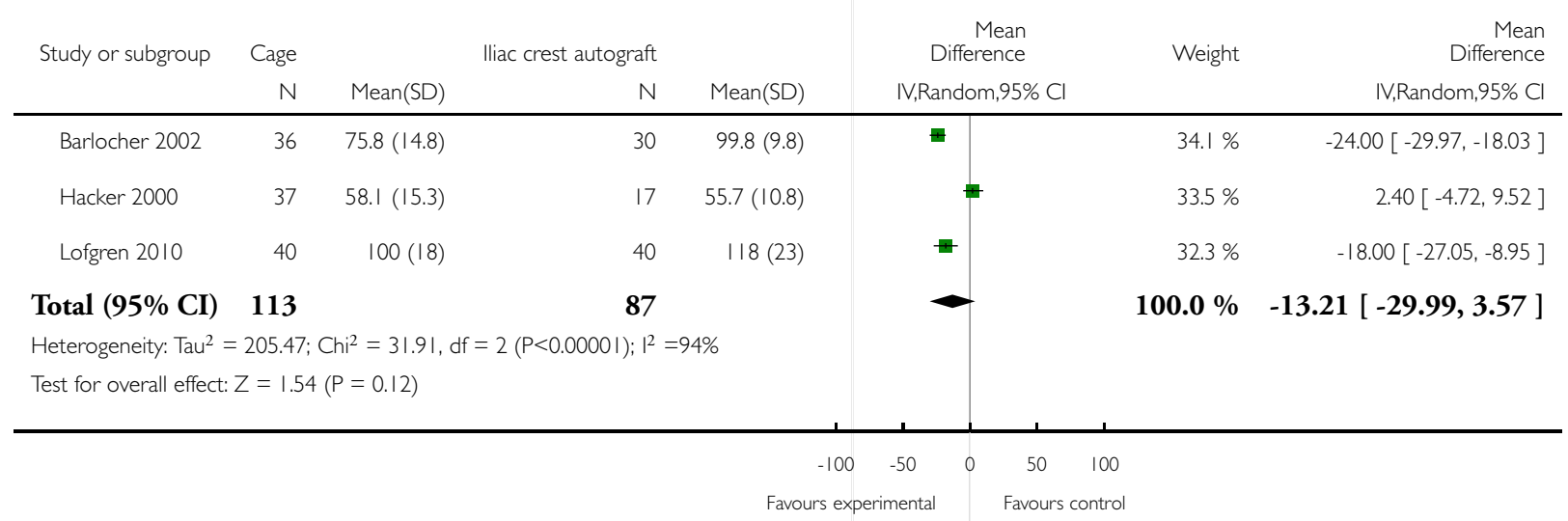




\section{Analysis 5.2. Comparison 5 Iliac crest autograft vs cage, Outcome 2 Blood loss.}

Review: Single or double-level anterior interbody fusion techniques for cervical degenerative disc disease

Comparison: 5 lliac crest autograft vs cage

Outcome: 2 Blood loss

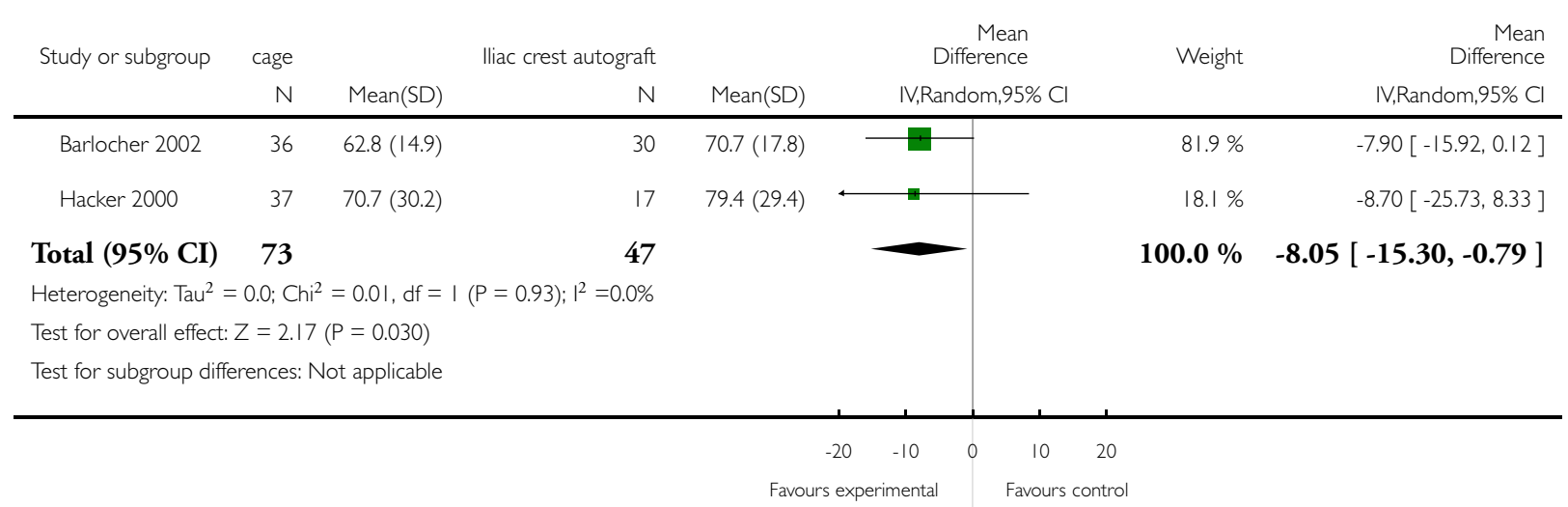

\section{Analysis 5.3. Comparison 5 lliac crest autograft vs cage, Outcome 3 Hospital stay.}

Review: Single or double-level anterior interbody fusion techniques for cervical degenerative disc disease

Comparison: 5 lliac crest autograft vs cage

Outcome: 3 Hospital stay

\begin{tabular}{|c|c|c|c|c|c|c|c|}
\hline \multirow[t]{2}{*}{ Study or subgroup } & \multirow{2}{*}{$\begin{array}{r}\text { Cage } \\
\mathrm{N}\end{array}$} & \multicolumn{3}{|c|}{ Iliac crest autograft } & \multirow{2}{*}{$\begin{array}{c}\text { Mean } \\
\text { Difference } \\
\text { IV,Random,95\% Cl }\end{array}$} & \multirow[t]{2}{*}{ Weight } & \multirow{2}{*}{$\begin{array}{r}\text { Mean } \\
\text { Difference } \\
\text { IV,Random,95\% Cl }\end{array}$} \\
\hline & & Mean(SD) & $N$ & Mean(SD) & & & \\
\hline Barlocher 2002 & 36 & $7(1.1)$ & 30 & $7.5(1.8)$ & $\rightarrow$ & $33.4 \%$ & $-0.50[-1.24,0.24]$ \\
\hline Celik 2007 & 35 & $2.3(1.7)$ & 30 & $2.4(2.1)$ & 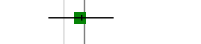 & $20.6 \%$ & $-0.10[-1.04,0.84]$ \\
\hline Lofgren 2010 & 40 & $3.6(1.1)$ & 40 & $4.1(1.7)$ & $\rightarrow$ & $46.1 \%$ & $-0.50[-1.13,0.13]$ \\
\hline
\end{tabular}

Total (95\% CI) 111

100

$100.0 \% \quad-0.42[-0.84,0.01]$

Heterogeneity: $\operatorname{Tau}^{2}=0.0 ; \mathrm{Chi}^{2}=0.55, \mathrm{df}=2(\mathrm{P}=0.76) ; \mathrm{I}^{2}=0.0 \%$

Test for overall effect: $Z=1.92(P=0.055)$

Test for subgroup differences: Not applicable

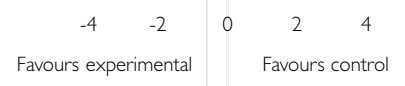




\section{Analysis 5.4. Comparison 5 Iliac crest autograft vs cage, Outcome 4 VAS Neck Pain.}

Review: Single or double-level anterior interbody fusion techniques for cervical degenerative disc disease

Comparison: 5 lliac crest autograft vs cage

Outcome: 4 VAS Neck Pain

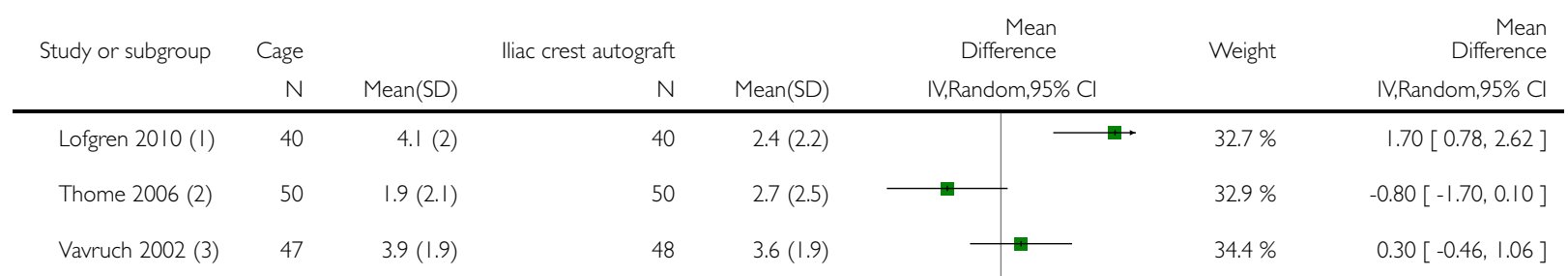

Total (95\% CI) 137

138

$100.0 \% \quad 0.40[-0.94,1.73]$

Heterogeneity: Tau $^{2}=1.20 ; \mathrm{Chi}^{2}=14.46, \mathrm{df}=2(\mathrm{P}=0.00073) ; \mathrm{I}^{2}=86 \%$

Test for overall effect: $Z=0.58(P=0.56)$

Test for subgroup differences: Not applicable

(I) Median, sd estimated from other studies, 2 years

(2) 12 months

(3) pain right now, SD estimated from other studies, 2 years

\section{Analysis 5.5. Comparison 5 Iliac crest autograft vs cage, Outcome 5 VAS Arm pain.}

Review: Single or double-level anterior interbody fusion techniques for cervical degenerative disc disease

Comparison: 5 lliac crest autograft vs cage

Outcome: 5 VAS Arm pain

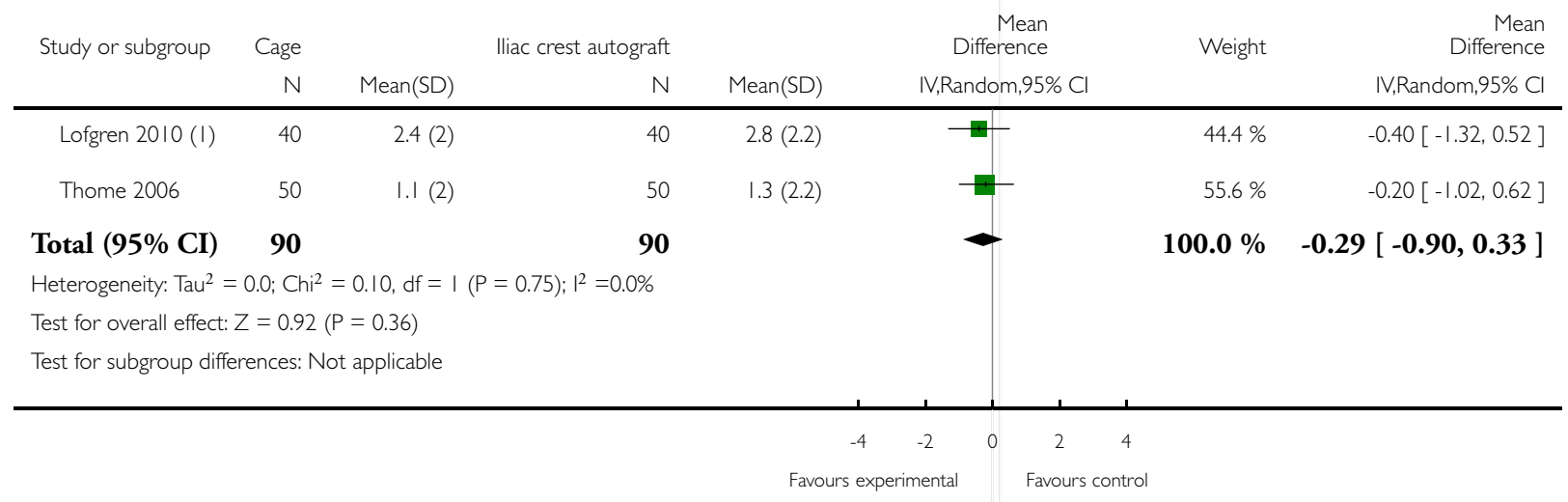

(I) 2 years, sd estimated from Thome 


\section{Analysis 5.6. Comparison 5 Iliac crest autograft vs cage, Outcome 6 Neck Disability Index (NDI).}

Review: Single or double-level anterior interbody fusion techniques for cervical degenerative disc disease

Comparison: 5 lliac crest autograft vs cage

Outcome: 6 Neck Disability Index (NDI)

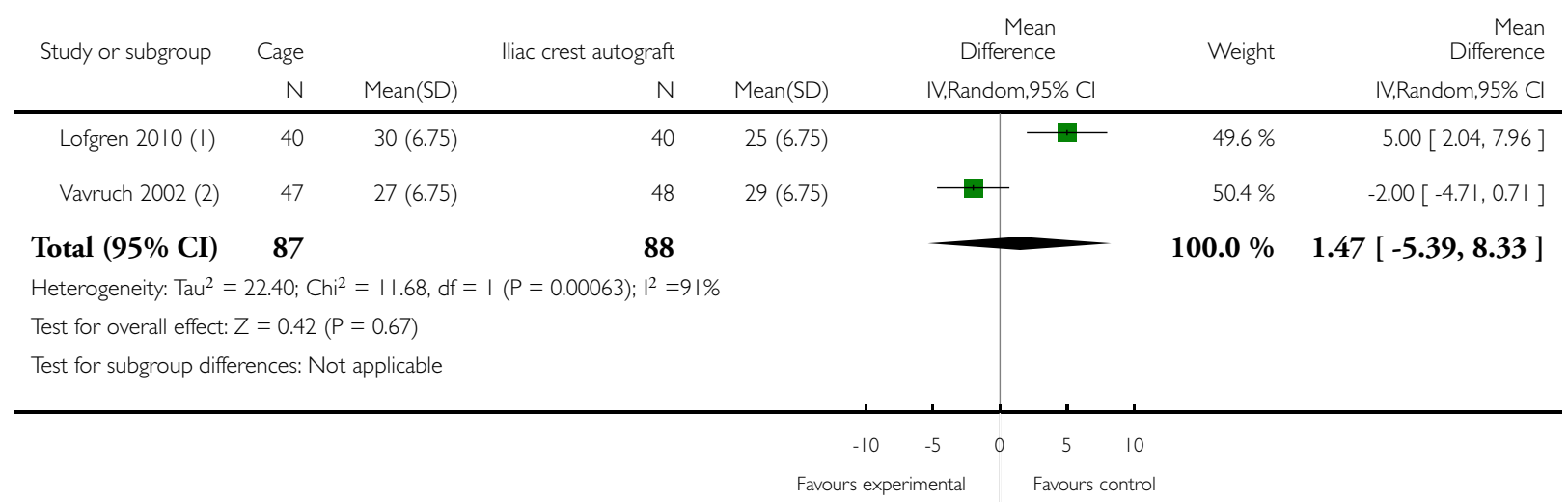

(I) 2 years, sd estimated from Vavruch

(2) 2 years, SD estimated from other study

\section{Analysis 5.7. Comparison 5 Iliac crest autograft vs cage, Outcome 7 JOA.}

Review: Single or double-level anterior interbody fusion techniques for cervical degenerative disc disease Comparison: 5 lliac crest autograft vs cage

Outcome: $7 \mathrm{JOA}$

\begin{tabular}{|c|c|c|c|c|c|c|c|c|}
\hline \multirow[t]{2}{*}{ Study or subgroup } & \multirow{2}{*}{$\begin{array}{r}\text { Cage } \\
\mathrm{N}\end{array}$} & \multicolumn{3}{|c|}{ \|liac crest autograft } & \multicolumn{2}{|r|}{$\begin{array}{r}\text { Mean } \\
\text { Difference }\end{array}$} & \multirow[t]{2}{*}{ Weight } & \multirow{2}{*}{$\begin{array}{r}\text { Mean } \\
\text { Difference } \\
\text { IV,Random,95\% Cl }\end{array}$} \\
\hline & & Mean(SD) & $\mathrm{N}$ & Mean(SD) & & IV,Random,95\% Cl & & \\
\hline Thome 2006 & 50 & I5.7 (1.6) & 50 & | $5.8(1.9)$ & & & $100.0 \%$ & $-0.10[-0.79,0.59]$ \\
\hline Total $(95 \% \mathrm{CI})$ & 50 & & 50 & & & & $100.0 \%$ & $-0.10[-0.79,0.59]$ \\
\hline \multicolumn{9}{|c|}{ Heterogeneity: not applicable } \\
\hline \multicolumn{9}{|c|}{ Test for overall effect: $Z=0.28(P=0.78)$} \\
\hline \multicolumn{9}{|c|}{ Test for subgroup differences: Not applicable } \\
\hline & & & & & -4 & -2 & 4 & \\
\hline & & & & Favol & & Favours & ntrol & \\
\hline
\end{tabular}




\section{Analysis 5.8. Comparison 5 Iliac crest autograft vs cage, Outcome 8 Odom's criteria.}

Review: Single or double-level anterior interbody fusion techniques for cervical degenerative disc disease

Comparison: 5 lliac crest autograft vs cage

Outcome: 8 Odom's criteria

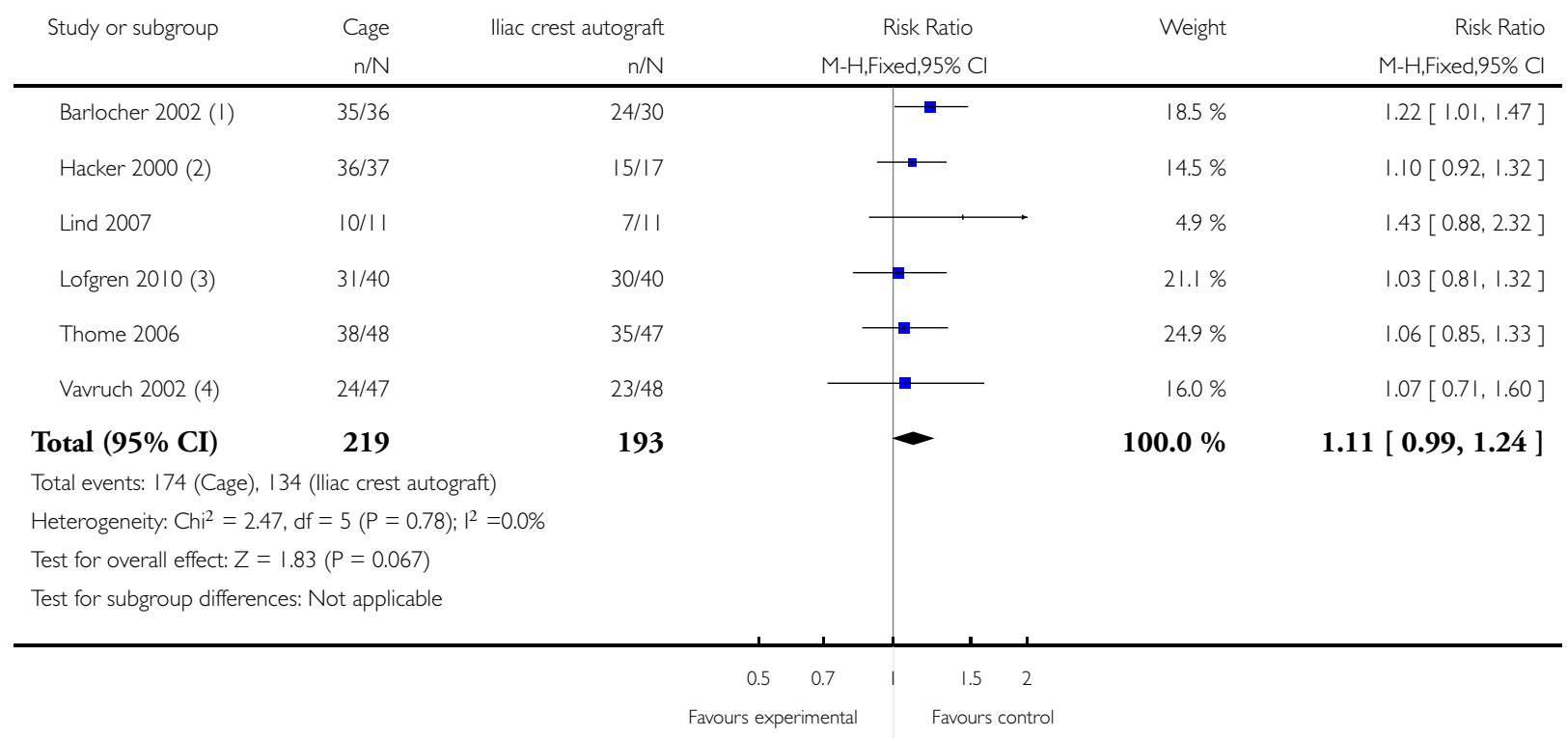
( I) 12 months
(2) Adapted Odom
(3) (adapted) Odom; 2 years
(4) 2 years

\section{Analysis 5.9. Comparison 5 Iliac crest autograft vs cage, Outcome 9 SF-36 Physical.}

Review: Single or double-level anterior interbody fusion techniques for cervical degenerative disc disease

Comparison: 5 lliac crest autograft vs cage

Outcome: 9 SF-36 Physical

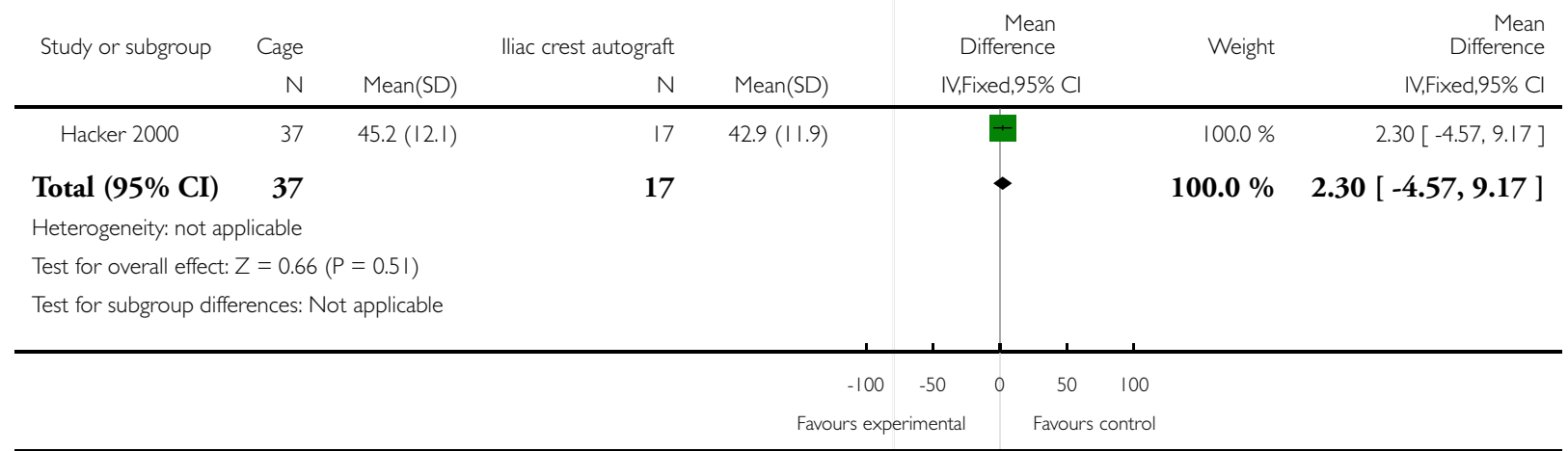




\section{Analysis 5.10. Comparison 5 lliac crest autograft vs cage, Outcome 10 SF-36 Mental.}

Review: Single or double-level anterior interbody fusion techniques for cervical degenerative disc disease

Comparison: 5 lliac crest autograft vs cage

Outcome: 10 SF-36 Mental

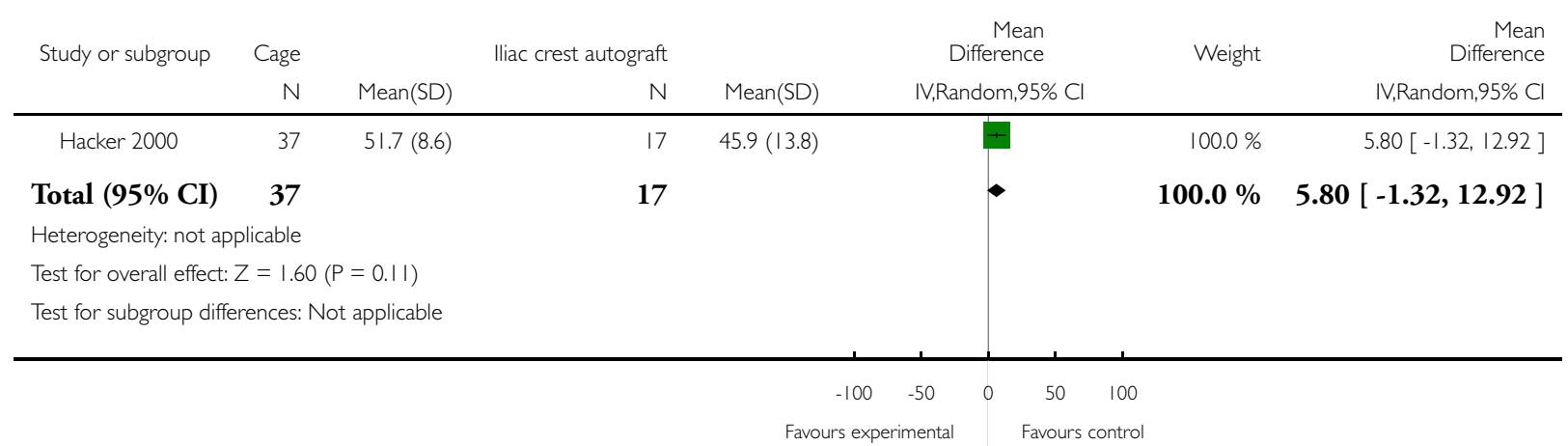

Analysis 5.I I. Comparison 5 lliac crest autograft vs cage, Outcome I I Satisfaction.

Review: Single or double-level anterior interbody fusion techniques for cervical degenerative disc disease

Comparison: 5 lliac crest autograft vs cage

Outcome: II Satisfaction

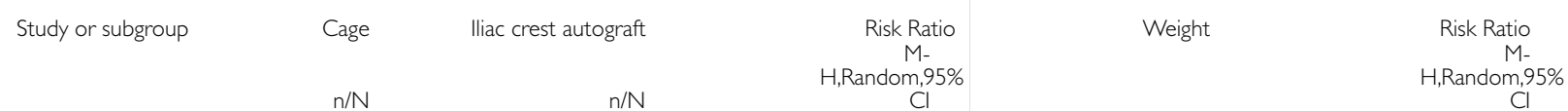

$\begin{array}{rrrrr}\text { Hacker } 2000 & 27 \mid / 346 & |14 /| 42 & 100.0 \% & 0.98[0.88,1.08] \\ \text { Total }(\mathbf{9 5} \% \mathbf{C I}) & \mathbf{3 4 6} & \mathbf{1 4 2} & \mathbf{1 0 0 . 0} \% & \mathbf{0 . 9 8}[\mathbf{0 . 8 8}, \mathbf{1 . 0 8}]\end{array}$

Total events: 27I (Cage), II4 (lliac crest autograft)

Heterogeneity: not applicable

Test for overall effect: $Z=0.49(P=0.62)$

Test for subgroup differences: Not applicable

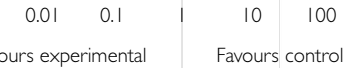




\section{Analysis 5.12. Comparison 5 Iliac crest autograft vs cage, Outcome I 2 Foraminal height.}

Review: Single or double-level anterior interbody fusion techniques for cervical degenerative disc disease

Comparison: 5 lliac crest autograft vs cage

Outcome: 12 Foraminal height

\begin{tabular}{|c|c|c|c|c|c|c|c|c|c|}
\hline \multirow[t]{2}{*}{ Study or subgroup } & \multirow{2}{*}{$\begin{array}{r}\text { Cage } \\
\mathrm{N}\end{array}$} & \multicolumn{2}{|c|}{ Autograft } & \multicolumn{4}{|c|}{$\begin{array}{r}\text { Mean } \\
\text { Difference }\end{array}$} & \multirow[t]{2}{*}{ Weight } & \multirow{2}{*}{$\begin{array}{r}\text { Mean } \\
\text { Difference } \\
\text { IV,Random, } 95 \% \text { Cl }\end{array}$} \\
\hline & & Mean(SD) & N & Mean(SD) & & & dom,95\% Cl & & \\
\hline Celik 2007 (I) & 35 & $9.6(1.2)$ & 30 & $8.1(1.5)$ & & & & $100.0 \%$ & $1.50[0.83,2.17]$ \\
\hline Total (95\% CI) & 35 & & 30 & & & & & $100.0 \%$ & $1.50[0.83,2.17]$ \\
\hline \multicolumn{10}{|c|}{ Heterogeneity: not applicable } \\
\hline \multicolumn{10}{|c|}{ Test for overall effect: $Z=4.40(P=0.0000 \mathrm{I} I)$} \\
\hline \multicolumn{10}{|c|}{ Test for subgroup differences: Not applicable } \\
\hline & & & & & -100 & -50 & 50 & 100 & \\
\hline \multicolumn{10}{|c|}{ Favours experimental $\quad$ Favours control } \\
\hline
\end{tabular}

(I) 18 months

\section{Analysis 5.13. Comparison 5 Iliac crest autograft vs cage, Outcome 13 Interspace height.}

Review: Single or double-level anterior interbody fusion techniques for cervical degenerative disc disease

Comparison: 5 lliac crest autograft vs cage

Outcome: 13 Interspace height

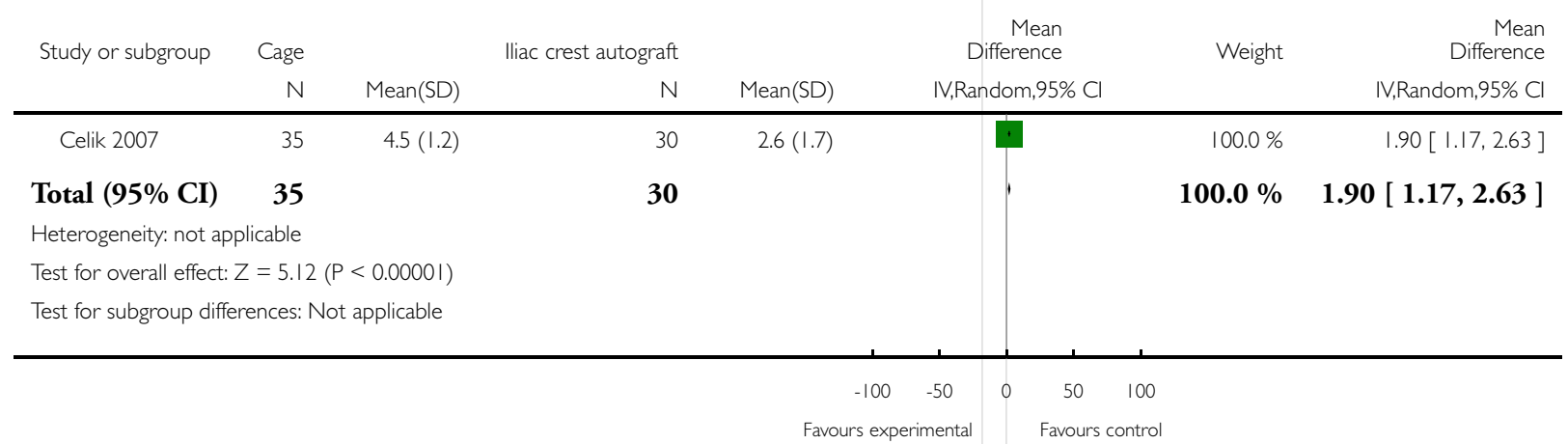


Analysis 5.14. Comparison 5 lliac crest autograft vs cage, Outcome 14 Cobb angle.

Review: Single or double-level anterior interbody fusion techniques for cervical degenerative disc disease

Comparison: 5 lliac crest autograft vs cage

Outcome: 14 Cobb angle

\begin{tabular}{|c|c|c|c|c|c|c|c|c|c|}
\hline \multirow[t]{2}{*}{ Study or subgroup } & \multirow{2}{*}{$\begin{array}{r}\text { Cage } \\
\mathrm{N}\end{array}$} & \multicolumn{2}{|c|}{ Iliac crest autograft } & \multicolumn{4}{|c|}{$\begin{array}{r}\text { Mean } \\
\text { Difference }\end{array}$} & \multirow[t]{2}{*}{ Weight } & \multirow{2}{*}{$\begin{array}{r}\text { Mean } \\
\text { Difference } \\
\text { IV,Random,95\% Cl }\end{array}$} \\
\hline & & Mean(SD) & N & Mean(SD) & & & idom,95\% Cl & & \\
\hline Celik 2007 (I) & 35 & $12.6(3.2)$ & 30 & | $1.8(3.8)$ & & & & $100.0 \%$ & $0.80[-0.92,2.52]$ \\
\hline Total (95\% CI) & 35 & & 30 & & & & 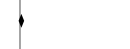 & $100.0 \%$ & $0.80[-0.92,2.52]$ \\
\hline \multicolumn{10}{|c|}{ Heterogeneity: not applicable } \\
\hline \multicolumn{10}{|c|}{ Test for overall effect: $Z=0.91(P=0.36)$} \\
\hline \multicolumn{10}{|c|}{ Test for subgroup differences: Not applicable } \\
\hline & & & & & -100 & -50 & 50 & 100 & \\
\hline \multicolumn{10}{|c|}{ Favours experimental $\quad$ Favours control } \\
\hline
\end{tabular}

(I) 18 months

\section{Analysis 5.15. Comparison 5 lliac crest autograft vs cage, Outcome 15 No Fusion.}

Review: Single or double-level anterior interbody fusion techniques for cervical degenerative disc disease

Comparison: 5 lliac crest autograft vs cage

Outcome: 15 No Fusion

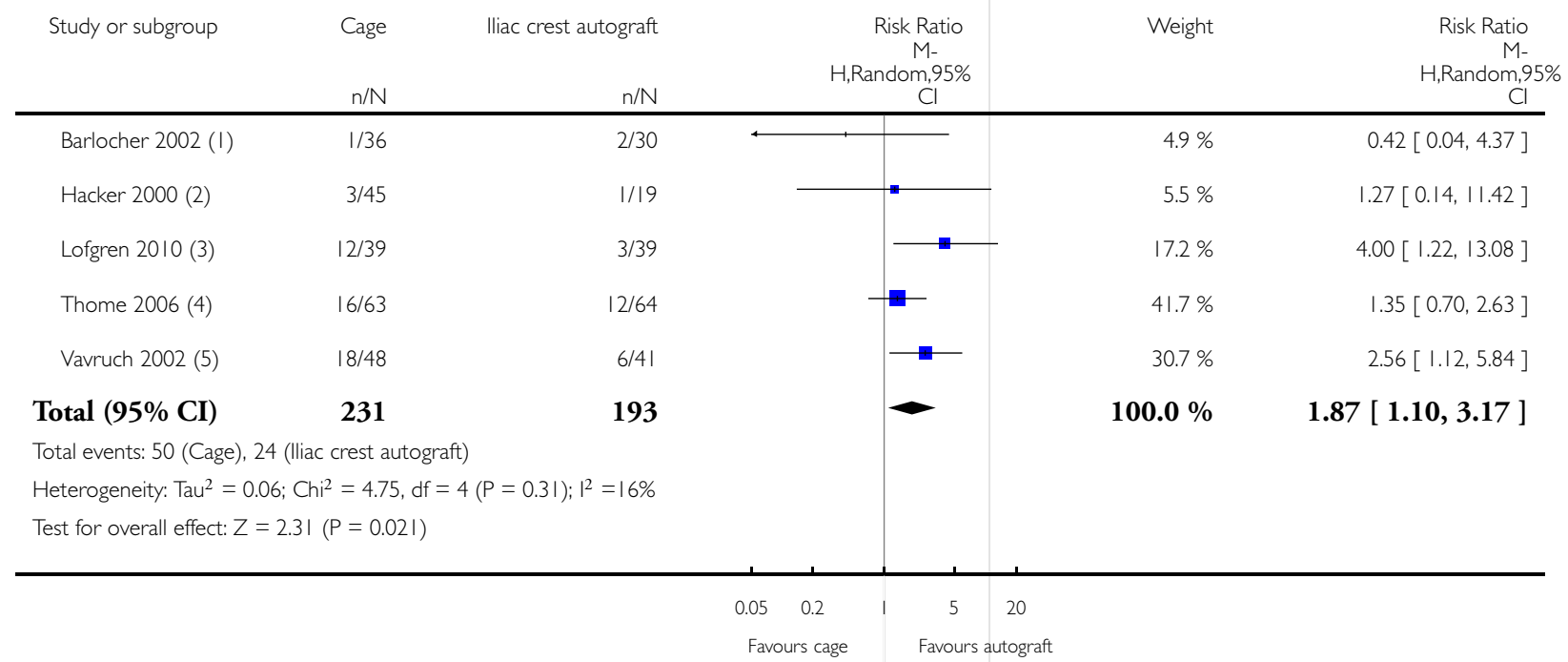

(1) 12 months

(2) 24 months

(3) 24 months

(4) 12 months

(5) 36 months, unclear if this concerns levels or patients

Single or double-level anterior interbody fusion techniques for cervical degenerative disc disease (Review)

Copyright (c) 20II The Cochrane Collaboration. Published by John Wiley \& Sons, Ltd. 


\section{Analysis 6.I. Comparison 6 lliac crest autograft vs iliac crest autograft with plates, Outcome I Clinical} outcome.

Review: Single or double-level anterior interbody fusion techniques for cervical degenerative disc disease

Comparison: 6 lliac crest autograft vs iliac crest autograft with plates

Outcome: I Clinical outcome

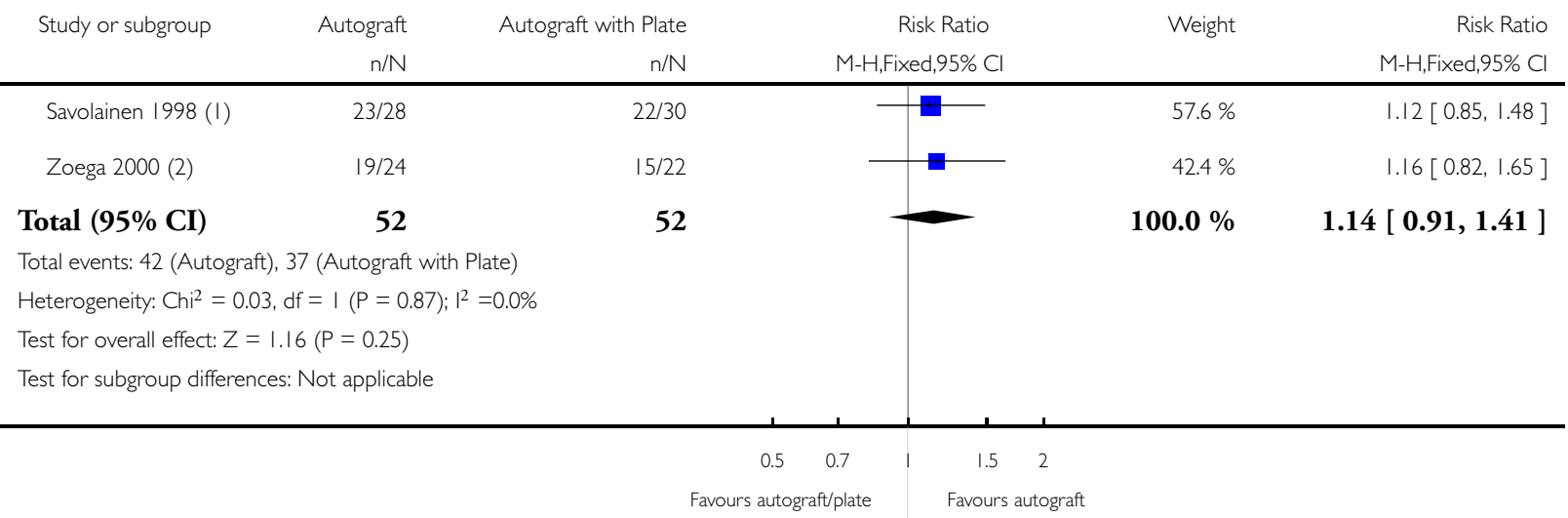
(I) 4 years
(2) Odoms criteria 
Analysis 6.2. Comparison 6 lliac crest autograft vs iliac crest autograft with plates, Outcome 2 No Fusion.

Review: Single or double-level anterior interbody fusion techniques for cervical degenerative disc disease

Comparison: 6 lliac crest autograft vs iliac crest autograft with plates

Outcome: 2 No Fusion

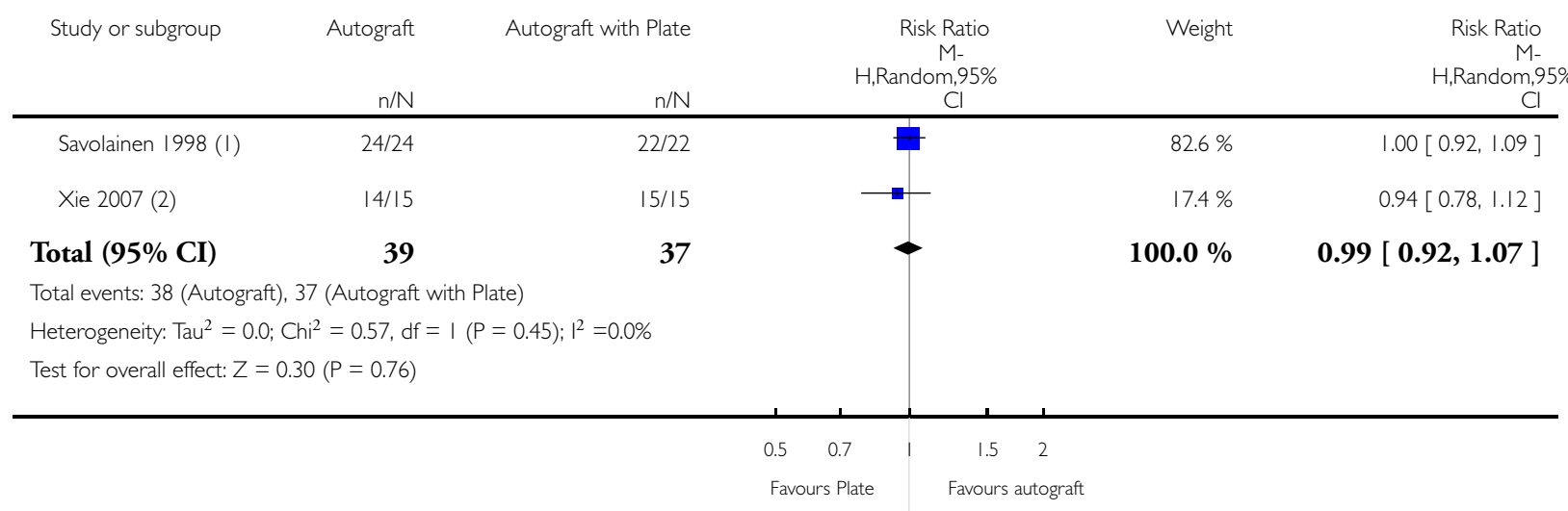

( 1 ) 4 years

(2) 2 years

Analysis 7.I. Comparison 7 Different types of autograft, Outcome I Fusion.

Review: Single or double-level anterior interbody fusion techniques for cervical degenerative disc disease

Comparison: 7 Different types of autograft

Outcome: I Fusion

\begin{tabular}{|c|c|c|c|c|c|}
\hline Study or subgroup & Cervical vertebrae & $\begin{array}{r}\text { lliac crest } \\
\mathrm{n} / \mathrm{N}\end{array}$ & $\begin{array}{c}\text { Risk Ratio } \\
\text { M- } \\
\text { H,Random,95\% } \\
\text { Cl } \\
\end{array}$ & Weight & $\begin{array}{c}\text { Risk Ratio } \\
\text { M- } \\
\text { H,Random,95\% } \\
\text { Cl } \\
\end{array}$ \\
\hline McGuire 1994 & $4 / 7$ & $40 / 43$ & & $100.0 \%$ & $0.61[0.32,1.17]$ \\
\hline Total (95\% CI) & 7 & 43 & & $100.0 \%$ & $0.61[0.32,1.17]$ \\
\hline \multicolumn{6}{|c|}{ Total events: 4 (Cervical vertebrae), 40 (lliac crest) } \\
\hline \multicolumn{6}{|c|}{ Heterogeneity: not applicable } \\
\hline \multicolumn{6}{|c|}{ Test for overall effect: $Z=1.48(P=0.14)$} \\
\hline Test for subgroup diff & Not applicable & & & & \\
\hline
\end{tabular}

Favours experimental Favours control 
Analysis 9.I. Comparison 9 Other comparisons between different types of instrumentation, Outcome I Odom's criteria.

Review: Single or double-level anterior interbody fusion techniques for cervical degenerative disc disease

Comparison: 9 Other comparisons between different types of instrumentation

Outcome: I Odom's criteria

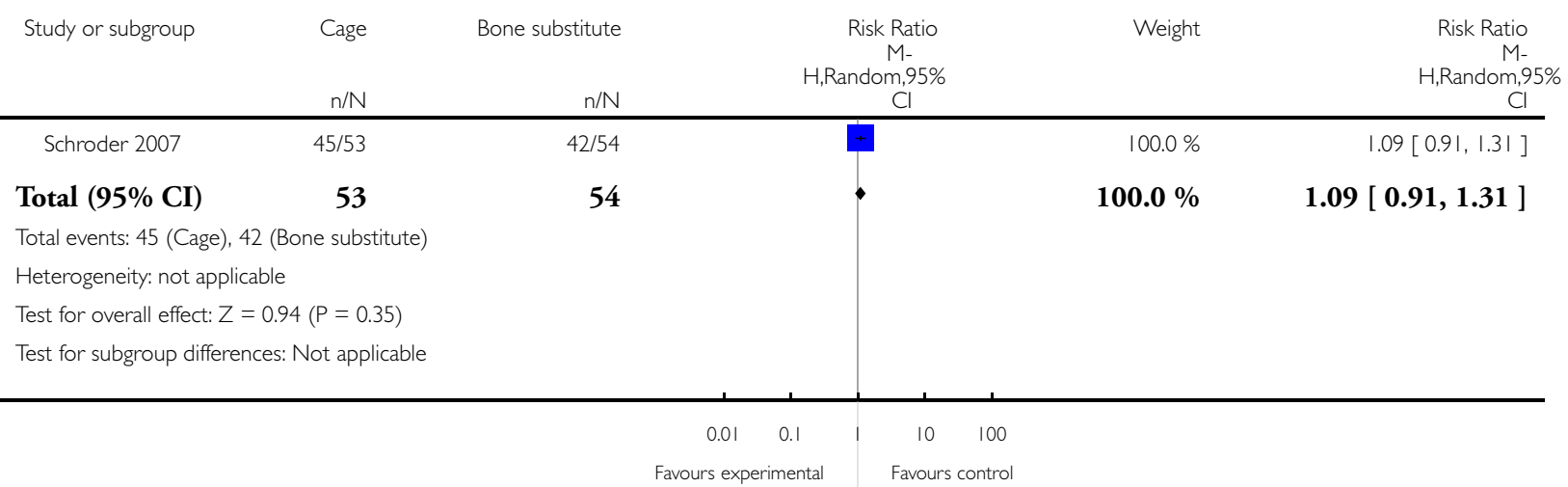

\section{Analysis 10.I. Comparison I0 PMMA vs cage, Outcome I Operation time.}

Review: Single or double-level anterior interbody fusion techniques for cervical degenerative disc disease

Comparison: 10 PMMA vs cage

Outcome: I Operation time

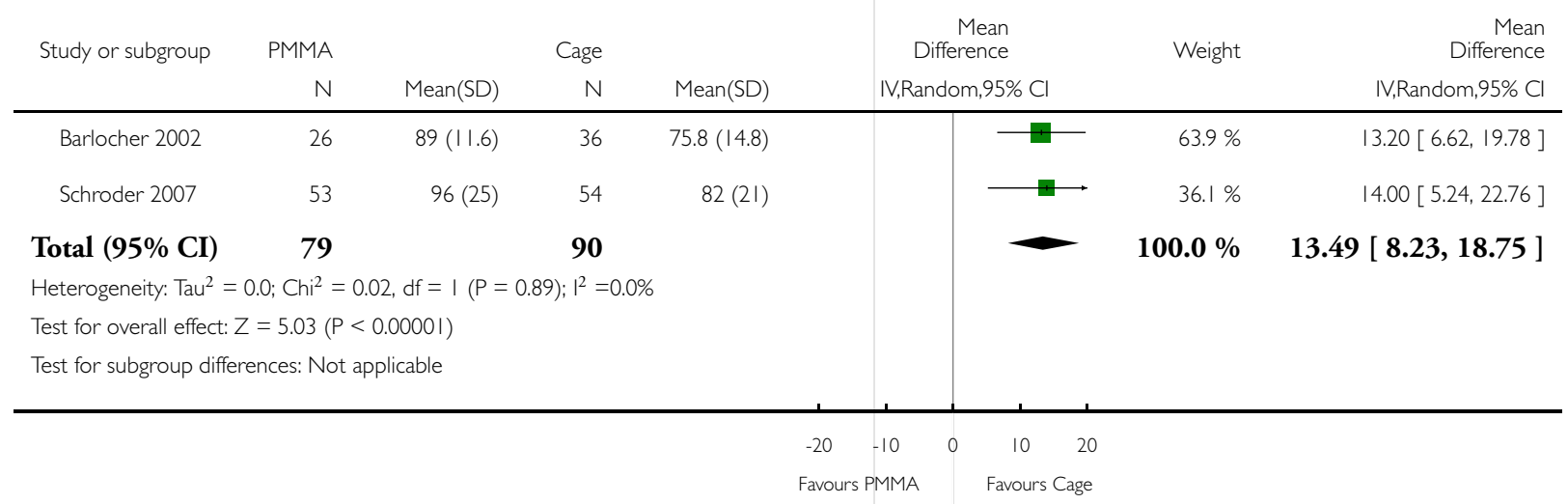


Analysis 10.2. Comparison 10 PMMA vs cage, Outcome 2 Odoms criteria.

Review: Single or double-level anterior interbody fusion techniques for cervical degenerative disc disease

Comparison: 10 PMMA vs cage

Outcome: 2 Odoms criteria

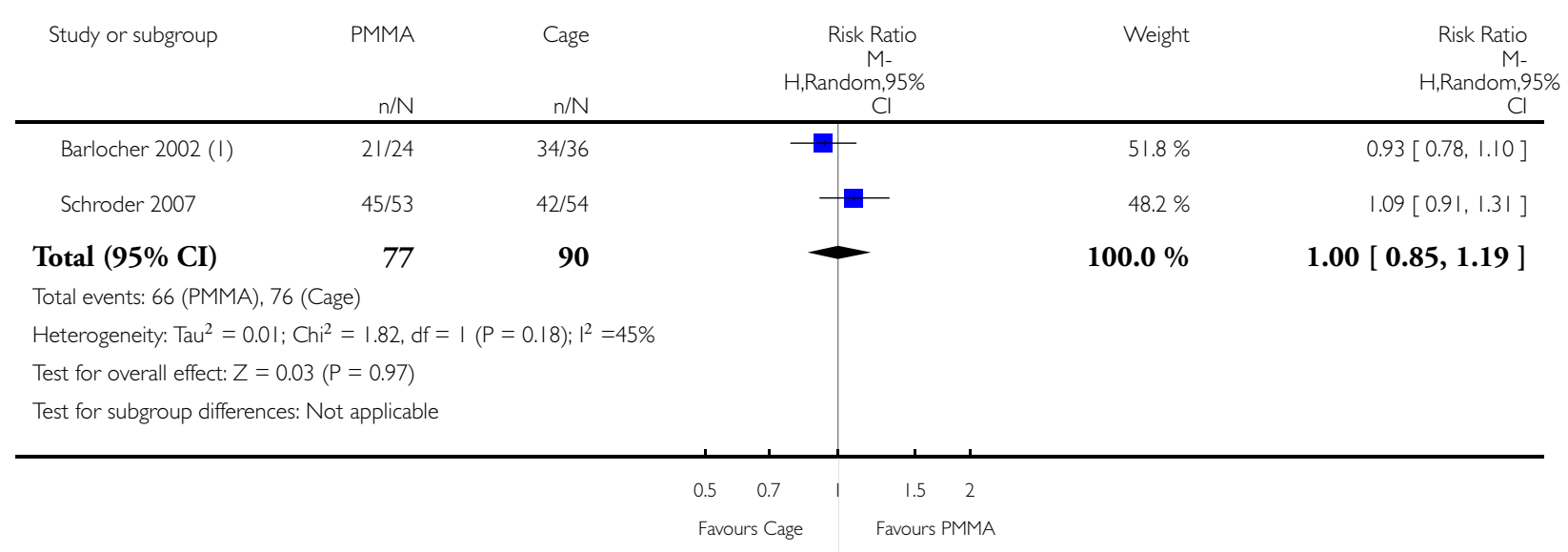

(I) 12 months

\section{Analysis 10.3. Comparison I0 PMMA vs cage, Outcome 3 No Fusion.}

Review: Single or double-level anterior interbody fusion techniques for cervical degenerative disc disease

Comparison: 10 PMMA vs cage

Outcome: 3 No Fusion

\begin{tabular}{|c|c|c|c|c|c|}
\hline Study or subgroup & $\begin{array}{l}\text { PMMA } \\
n / N \\
\end{array}$ & $\begin{array}{l}\text { Cage } \\
\mathrm{n} / \mathrm{N}\end{array}$ & $\begin{array}{c}\text { Risk Ratio } \\
\text { M- } \\
\text { H,Random,95\% } \\
\mathrm{Cl}\end{array}$ & Weight & $\begin{array}{c}\text { Risk Ratio } \\
\text { M- } \\
\text { H,Random,95\% } \\
\mathrm{Cl}\end{array}$ \\
\hline Barlocher 2002 & $24 / 24$ & $1 / 36$ & $\rightarrow-$ & $45.8 \%$ & $24.17[5.04,116.02]$ \\
\hline Schroder 2007 (I) & $18 / 53$ & $7 / 54$ & 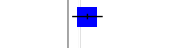 & $54.2 \%$ & $2.62[1.19,5.75]$ \\
\hline Total $(95 \% \mathrm{CI})$ & 77 & 90 & - & $100.0 \%$ & $7.25[0.70,74.75]$ \\
\hline \multicolumn{6}{|c|}{ Total events: 42 (PMMA), 8 (Cage) } \\
\hline \multicolumn{6}{|c|}{ Heterogeneity: $\operatorname{Tau}^{2}=2.45 ; \mathrm{Chi}^{2}=7.12, \mathrm{df}=1(P=0.01) ;\left.\right|^{2}=86 \%$} \\
\hline \multicolumn{6}{|c|}{ Test for overall effect: $Z=1.66(P=0.096)$} \\
\hline \multicolumn{6}{|c|}{ Test for subgroup differences: Not applicable } \\
\hline
\end{tabular}

(1) 24 months 


\section{Analysis II.I. Comparison I I Cage vs cage and plate, Outcome I Neck pain.}

Review: Single or double-level anterior interbody fusion techniques for cervical degenerative disc disease

Comparison: I I Cage vs cage and plate

Outcome: I Neck pain

\begin{tabular}{|c|c|c|c|c|c|c|c|c|c|}
\hline \multirow[t]{2}{*}{ Study or subgroup } & Cage and plate & \multicolumn{3}{|c|}{ Cage } & \multicolumn{3}{|c|}{$\begin{array}{r}\text { Mean } \\
\text { Difference }\end{array}$} & \multirow[t]{2}{*}{ Weight } & \multirow{2}{*}{$\begin{array}{r}\text { Mean } \\
\text { Difference } \\
\text { IV,Random, } 95 \% \mathrm{Cl}\end{array}$} \\
\hline & $\mathrm{N}$ & Mean(SD) & $\mathrm{N}$ & Mean(SD) & & $\mathrm{IV}, \mathrm{R}$ & dom,95\% Cl & & \\
\hline Nabhan 2007 (I) & 18 & $2(0.5)$ & 19 & $1.7(0.3)$ & & & $\because$ & $100.0 \%$ & $0.30[0.03,0.57]$ \\
\hline Total (95\% CI) & 18 & & 19 & & & & - & $100.0 \%$ & $0.30[0.03,0.57]$ \\
\hline \multicolumn{10}{|c|}{ Heterogeneity: not applicable } \\
\hline \multicolumn{10}{|c|}{ Test for overall effect: $Z=2.20(P=0.028)$} \\
\hline \multicolumn{10}{|c|}{ Test for subgroup differences: Not applicable } \\
\hline & & & & & -2 & -1 & 0 & 2 & \\
\hline \multicolumn{10}{|c|}{ Favours experimental $\quad$ Favours control } \\
\hline
\end{tabular}

( I) 24 months

\section{Analysis II.2. Comparison II Cage vs cage and plate, Outcome 2 Arm pain.}

Review: Single or double-level anterior interbody fusion techniques for cervical degenerative disc disease

Comparison: II Cage vs cage and plate

Outcome: 2 Arm pain

\begin{tabular}{|c|c|c|c|c|c|c|c|c|}
\hline \multirow{3}{*}{$\begin{array}{l}\text { Study or subgroup } \\
\text { Nabhan } 2007 \text { (I) }\end{array}$} & \multirow{3}{*}{$\begin{array}{r}\text { Plate } \\
\mathrm{N} \\
18\end{array}$} & \multirow{3}{*}{\multicolumn{2}{|c|}{$\begin{array}{r}\text { cage } \\
\mathrm{N} \\
19\end{array}$}} & \multirow{2}{*}{\multicolumn{3}{|c|}{$\begin{array}{c}\text { Mean } \\
\text { Difference } \\
\text { IV,Random,95\% Cl }\end{array}$}} & \multirow[t]{2}{*}{ Weight } & \multirow{3}{*}{$\begin{array}{r}\text { Mean } \\
\text { Difference } \\
\text { IV,Random,95\% Cl } \\
-0.60[-0.80,-0.40]\end{array}$} \\
\hline & & & & & & & & \\
\hline & & & & $2.1(0.4)$ & & + & $100.0 \%$ & \\
\hline Total $(95 \% \mathrm{CI})$ & 18 & & 19 & & & $\bullet$ & $100.0 \%$ & $-0.60[-0.80,-0.40]$ \\
\hline \multicolumn{9}{|c|}{ Heterogeneity: not applicable } \\
\hline \multicolumn{9}{|c|}{ Test for overall effect: $Z=5.82(P<0.0000 \mathrm{I})$} \\
\hline \multicolumn{9}{|c|}{ Test for subgroup differences: Not applicable } \\
\hline & & & & & . & -1 & 2 & \\
\hline & & & & & Fav & Favours & & \\
\hline
\end{tabular}

\section{(1) 2 years}


Analysis II.3. Comparison II Cage vs cage and plate, Outcome 3 JOA.

Review: Single or double-level anterior interbody fusion techniques for cervical degenerative disc disease

Comparison: I I Cage vs cage and plate

Outcome: $3 \mathrm{JOA}$

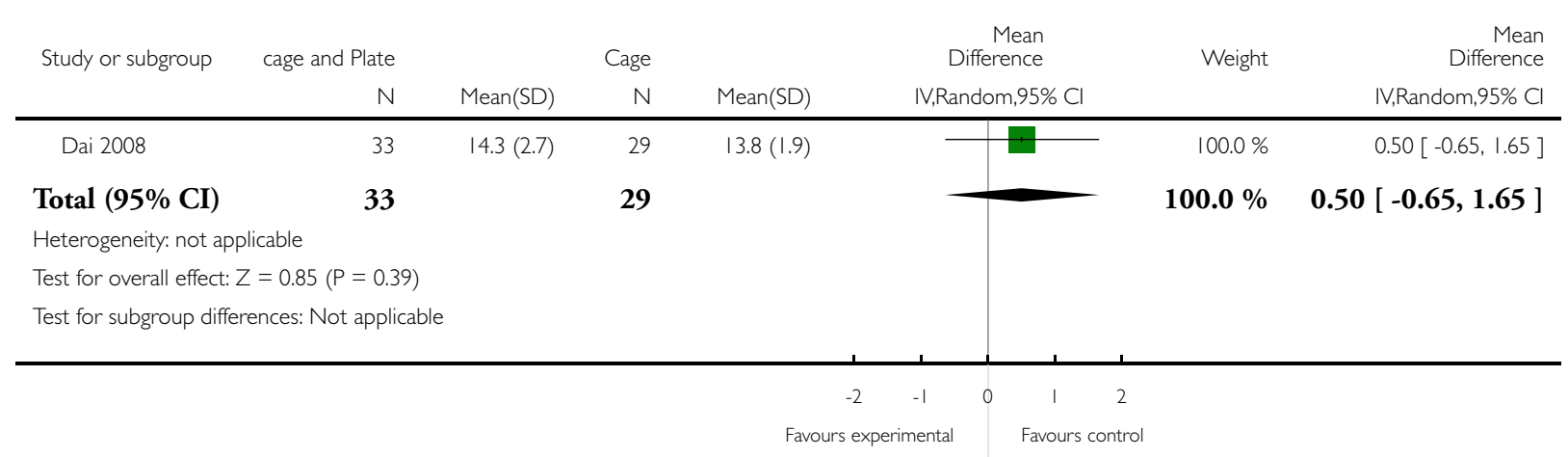

\section{Analysis I I.4. Comparison I I Cage vs cage and plate, Outcome 4 Segmental lordosis.}

Review: Single or double-level anterior interbody fusion techniques for cervical degenerative disc disease

Comparison: I I Cage vs cage and plate

Outcome: 4 Segmental lordosis

\begin{tabular}{|c|c|c|c|c|c|c|c|c|}
\hline \multirow[t]{2}{*}{ Study or subgroup } & \multirow{2}{*}{$\begin{array}{r}\text { Cage and plate } \\
N\end{array}$} & \multicolumn{3}{|c|}{ cage } & \multicolumn{2}{|r|}{$\begin{array}{r}\text { Mean } \\
\text { Difference }\end{array}$} & \multirow[t]{2}{*}{ Weight } & \multirow{2}{*}{$\begin{array}{r}\text { Mean } \\
\text { Difference } \\
\text { IV,Random,95\% Cl }\end{array}$} \\
\hline & & Mean(SD) & N & Mean(SD) & & IV,Random,95\% Cl & & \\
\hline Dai 2008 & 33 & $3.2(4.6)$ & 29 & $3.8(4.8)$ & & $\bar{\tau}$ & $100.0 \%$ & $-0.60[-2.95,1.75]$ \\
\hline Total (95\% CI) & 33 & & 29 & & & & $100.0 \%$ & $-0.60[-2.95,1.75]$ \\
\hline \multicolumn{9}{|c|}{ Heterogeneity: not applicable } \\
\hline \multicolumn{9}{|c|}{ Test for overall effect: $Z=0.50(P=0.62)$} \\
\hline \multicolumn{9}{|c|}{ Test for subgroup differences: Not applicable } \\
\hline & & & & & -4 & -2 & 4 & \\
\hline & & & & & & Favour & trol & \\
\hline
\end{tabular}




\section{Analysis 12.I. Comparison 12 Complications, Outcome I complications.}

Review: Single or double-level anterior interbody fusion techniques for cervical degenerative disc disease

Comparison: 12 Complications

Outcome: I complications

\begin{tabular}{|c|c|c|c|c|}
\hline Study or subgroup & Experimental & Control & Risk Ratio & Risk Ratio \\
\hline & $\mathrm{n} / \mathrm{N}$ & $\mathrm{n} / \mathrm{N}$ & M-H,Fixed,95\% Cl & M-H,Fixed,95\% Cl \\
\hline \multicolumn{5}{|c|}{ I Discectomy alone versus human bone graft } \\
\hline Abd-Alrahman $1999(1)$ & $2 / 50$ & $0 / 40$ & & $4.02[0.20,81.42]$ \\
\hline Barlocher 2002 (2) & $4 / 30$ & $2 / 33$ & $\longrightarrow$ & $2.20[0.43,11.16]$ \\
\hline Dowd 1999 (3) & $1 / 40$ & $2 / 44$ & & $0.55[0.05,5.84]$ \\
\hline Martins 1976 (4) & $0 / 26$ & $1 / 25$ & & $0.32[0.01,7.53]$ \\
\hline Rosenorn 1983 (5) & $0 / 31$ & $0 / 32$ & & $0.0[0.0,0.0]$ \\
\hline Savolainen $1998(6)$ & $5 / 30$ & $3 / 31$ & $\longrightarrow$ & $1.72[0.45,6.58]$ \\
\hline Xie 2007 (7) & $1 / 15$ & $0 / 15$ & & $3.00[0.13,68.26]$ \\
\hline Subtotal $(95 \%$ CI $)$ & 222 & 220 & & $1.56[0.71,3.43]$ \\
\hline \multicolumn{5}{|c|}{ Total events: I 3 (Experimental), 8 (Control) } \\
\hline \multicolumn{5}{|c|}{ Heterogeneity: $\mathrm{Chi}^{2}=2.45, \mathrm{df}=5(\mathrm{P}=0.78) ; \mathrm{I}^{2}=0.0 \%$} \\
\hline \multicolumn{5}{|c|}{ Test for overall effect: $Z=1.10(P=0.27)$} \\
\hline \multicolumn{5}{|l|}{2 Discectomy alone vs cage } \\
\hline Barlocher 2002 (8) & $0 / 36$ & $2 / 33$ & - & $0.18[0.01,3.69]$ \\
\hline Hauerberg 2008 (9) & $0 / 41$ & $0 / 47$ & & $0.0[0.0,0.0]$ \\
\hline Ruetten 2009 ( 10$)$ & 0/49 & $0 / 54$ & & $0.0[0.0,0.0]$ \\
\hline Subtotal (95\% CI) & 126 & 134 & & $0.18[0.01,3.69]$ \\
\hline \multicolumn{5}{|c|}{ Total events: 0 (Experimental), 2 (Control) } \\
\hline \multicolumn{5}{|c|}{ Heterogeneity: $\mathrm{Chi}^{2}=0.0, \mathrm{df}=0(\mathrm{P}=1.00) ; \mathrm{I}^{2}=0.0 \%$} \\
\hline \multicolumn{5}{|c|}{ Test for overall effect: $Z=1.11(P=0.27)$} \\
\hline \multicolumn{5}{|l|}{3 Discectomy alone vs PMMA } \\
\hline Barlocher 2002 (I I) & $0 / 26$ & $2 / 33$ & & $0.25[0.01,5.03]$ \\
\hline van den Bent 1996 & $0 / 42$ & $0 / 39$ & & $0.0[0.0,0.0]$ \\
\hline Subtotal (95\% CI) & 68 & 72 & & $0.25[0.01,5.03]$ \\
\hline \multicolumn{5}{|c|}{ Total events: 0 (Experimental), 2 (Control) } \\
\hline \multicolumn{5}{|c|}{ Heterogeneity: $\mathrm{Chi}^{2}=0.0, \mathrm{df}=0(\mathrm{P}=1.00) ; \mathrm{I}^{2}=0.0 \%$} \\
\hline \multicolumn{5}{|c|}{ Test for overall effect: $Z=0.90(P=0.37)$} \\
\hline \multicolumn{5}{|c|}{4 Discectomy alone vs iliac crest autograft with plates } \\
\hline Oktenoglu 2007 (I2) & 0/9 & $0 / 11$ & & $0.0[0.0,0.0]$ \\
\hline Savolainen 1998 (13) & $5 / 30$ & $5 / 31$ & $\longrightarrow$ & $1.03[0.33,3.21]$ \\
\hline Xie 2007 (14) & $0 / 15$ & $0 / 15$ & & $0.0[0.0,0.0]$ \\
\hline Subtotal (95\% CI) & 54 & 57 & & $1.03[0.33,3.21]$ \\
\hline \multicolumn{5}{|c|}{ Total events: 5 (Experimental), 5 (Control) } \\
\hline \multicolumn{5}{|c|}{ (38) Rigid plate 4 hardware failures } \\
\hline & & & & (Continued....) \\
\hline
\end{tabular}




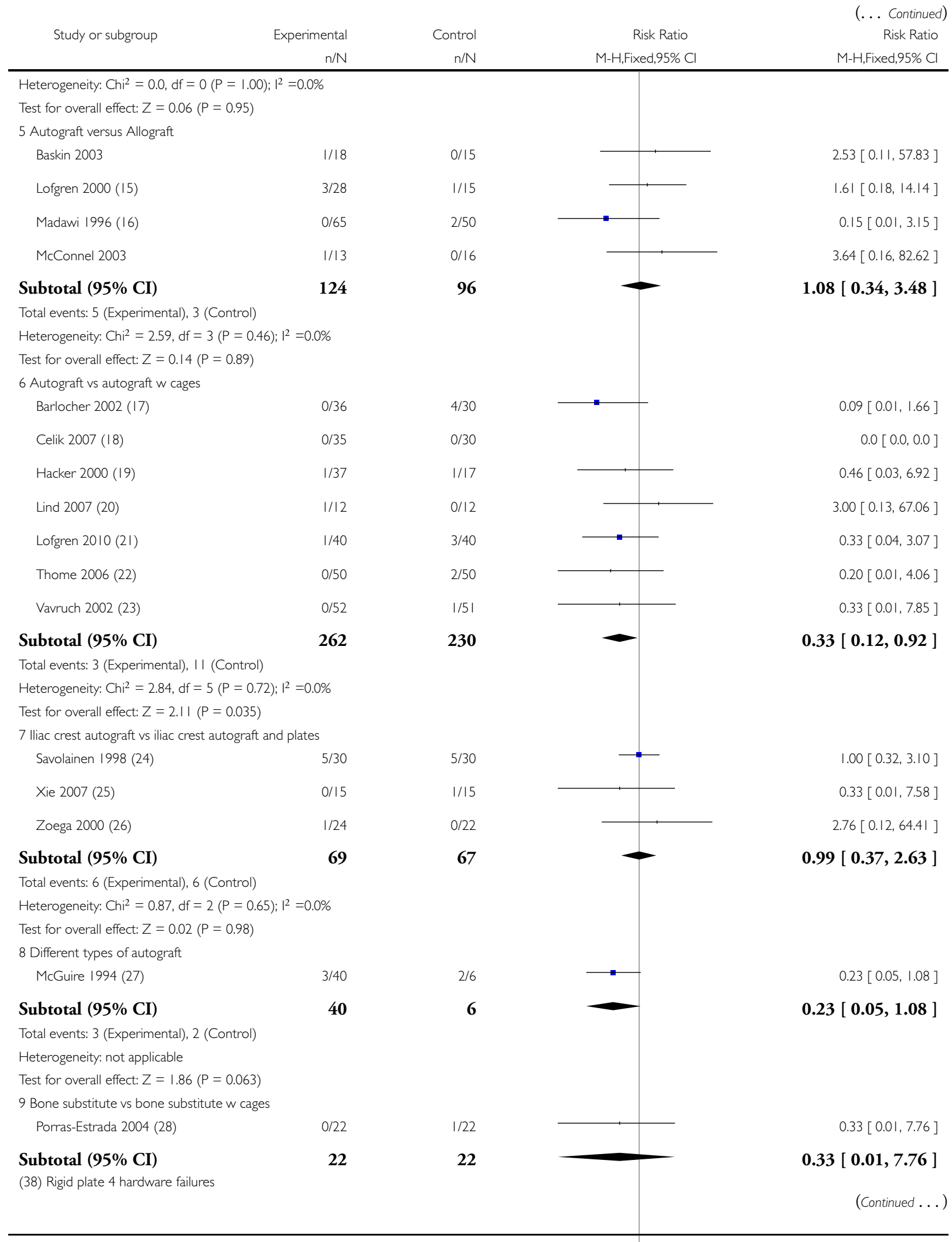




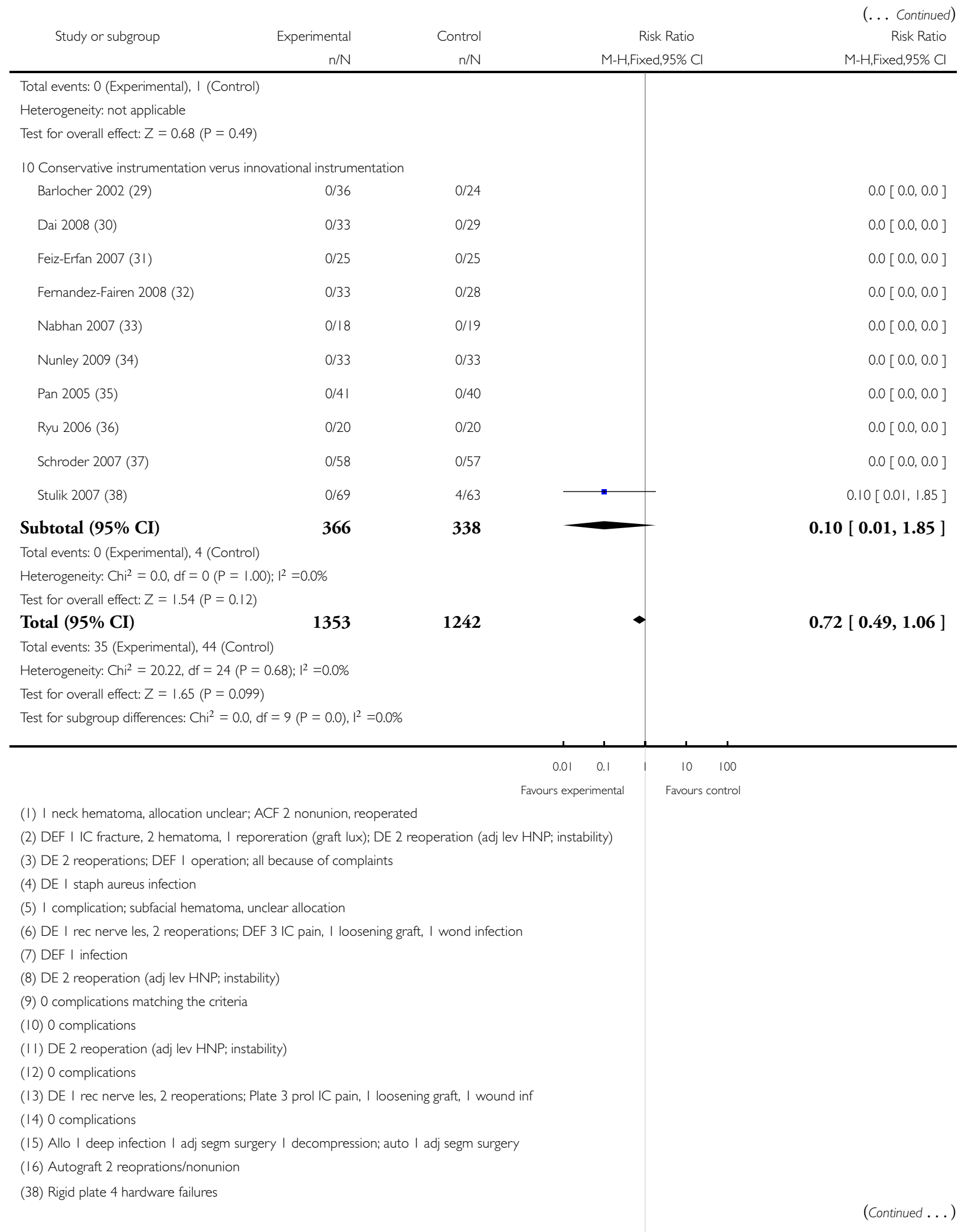


Table 1. Definitions (Continued)

Allograft

Implant material from any other source than the same individual, usually obtained from another human and stored and treated in a bone bank. For example, a ring from a femoral bone can be used

Table 2. Assessment of clinical relevance

\begin{tabular}{|c|c|c|c|c|c|c|}
\hline Study & $\begin{array}{l}\text { Clinical } \\
\text { relevance }\end{array}$ & $\begin{array}{l}\text { Patient descrip- } \\
\text { tion }\end{array}$ & $\begin{array}{l}\text { Intervention } \\
\text { description }\end{array}$ & $\begin{array}{l}\text { Outcome mea- } \\
\text { sures }\end{array}$ & Effect size & Benefits/harms \\
\hline $\begin{array}{l}\text { Abd-Alrahman } \\
1999\end{array}$ & & Yes & Yes & No & No & Unsure \\
\hline Barlocher 2002 & Yes & Unsure & Yes & Yes & No & Yes \\
\hline Baskin 2003 & & Yes & Unsure & Yes & Unsure & Unsure \\
\hline Celik 2007 & No & No & No & No & No & No \\
\hline Dai 2008 & Unsure & Yes & Yes & Yes & No & No \\
\hline Dowd 1999 & & No & Yes & Yes & Unsure & Unsure \\
\hline Feiz-Erfan 2007 & No & No & No & Yes & Yes & Unsure \\
\hline $\begin{array}{l}\text { Fernandez- } \\
\text { Fairen } 2008\end{array}$ & Yes & Yes & Yes & Yes & Yes & No \\
\hline Hacker 2000 & & Yes & Yes & Yes & No & Unsure \\
\hline Hauerberg 2008 & Yes & Yes & Yes & No & No & No \\
\hline Lind 2007 & No & No & No & No & No & No \\
\hline Lofgren 2000 & & Yes & Yes & Yes & No & Unsure \\
\hline Lofgren 2010 & Yes & Yes & Yes & Yes & No & No \\
\hline Madawi 1996 & & Unsure & Unsure & No & No & Unsure \\
\hline Martins 1976 & & Yes & Yes & No & No & Unsure \\
\hline McConnel 2003 & & Unsure & Yes & No & No & Unsure \\
\hline McGuire 1994 & & Yes & Unsure & No & Unsure & No \\
\hline Nabhan 2007 & No & No & Yes & No & No & No \\
\hline Nunley 2009 & Yes & Yes & Yes & No & No & No \\
\hline
\end{tabular}


Table 2. Assessment of clinical relevance (Continued)

\begin{tabular}{|c|c|c|c|c|c|c|}
\hline Oktenoglu 2007 & No & Yes & yes & No & No & No \\
\hline Pan 2005 & Unsure & Yes & Yes & Yes & Unsure & Yes \\
\hline $\begin{array}{l}\text { Porras-Estrada } \\
2004\end{array}$ & No & Yes & Yes & No & Yes & Unsure \\
\hline Rosenorn 1983 & & Yes & Yes & No & Yes & Yes \\
\hline Ruetten 2009 & Yes & Yes & Yes & Yes & No & No \\
\hline Ryu 2006 & Yes & Yes & Yes & Yes & No & No \\
\hline Savolainen 1998 & & Yes & Yes & No & No & Unsure \\
\hline Schroder 2007 & No & No & No & No & Yes & Yes \\
\hline Stulik 2007 & No & Yes & No & No & No & Unsure \\
\hline Thome 2006 & Yes & No & Yes & Yes & Unsure & Unsure \\
\hline $\begin{array}{l}\text { van den Bent } \\
1996\end{array}$ & & Yes & Yes & No & No & No \\
\hline Vavruch 2002 & & Yes & Yes & Yes & No & Unsure \\
\hline Xie 2007 & No & Yes & Yes & Yes & No & No \\
\hline Zoega 2000 & & Yes & Yes & Yes & No & Unsure \\
\hline
\end{tabular}

\section{A P P E N D I C E S}

\section{Appendix I. Criteria and operationalisation for Risk of Bias Assessment - RCTs and CCTs}

1. Was the method of randomisation adequate? A random (unpredictable) assignment sequence. Examples of adequate methods are coin toss (for studies with two groups), rolling a dice (for studies with two or more groups), drawing of balls of different colours, drawing of ballots with the study group labels from a dark bag, computer-generated random sequence, pre-ordered sealed envelops, sequentially-ordered vials, telephone call to a central office, and pre-ordered list of treatment assignments

Examples of inadequate methods are: alternation, birth date, social insurance/security number, date in which they are invited to participate in the study, and hospital registration number

2. Was the treatment allocation concealed? Assignment generated by an independent person not responsible for determining the eligibility of the patients. This person has no information about the persons included in the trial and has no influence on the assignment sequence or on the decision about eligibility of the patient.

Was knowledge of the allocated interventions adequately prevented during the study?

3. Was the patient blinded to the intervention? 
This item should be scored "yes" if the index and control groups are indistinguishable for the patients or if the success of blinding was tested among the patients and it was successful.

4. Was the care provider blinded to the intervention? This item should be scored "yes" if the index and control groups are indistinguishable for the care providers or if the success of blinding was tested among the care providers and it was successful

5. Was the outcome assessor blinded to the intervention? Adequacy of blinding should be assessed for the primary outcomes. This item should be scored "yes" if the success of blinding was tested among the outcome assessors and it was successful or:

- for patient-reported outcomes in which the patient is the outcome assessor (e.g., pain, disability): the blinding procedure is adequate for outcome assessors if participant blinding is scored "yes"

- for outcome criteria assessed during scheduled visit and that supposes a contact between participants and outcome assessors (e.g., clinical examination): the blinding procedure is adequate if patients are blinded, and the treatment or adverse effects of the treatment cannot be noticed during clinical examination

- for outcome criteria that do not suppose a contact with participants (e.g., radiography, magnetic resonance imaging): the blinding procedure is adequate if the treatment or adverse effects of the treatment cannot be noticed when assessing the main outcome

- for outcome criteria that are clinical or therapeutic events that will be determined by the interaction between patients and care providers (e.g., co-interventions, hospitalisation length, treatment failure), in which the care provider is the outcome assessor: the blinding procedure is adequate for outcome assessors if the item for 'caregivers' is scored "yes"

- for outcome criteria that are assessed from data of the medical forms: the blinding procedure is adequate if the treatment or adverse effects of the treatment cannot be noticed on the extracted data

Were incomplete outcome data adequately addressed?

6. Was the drop-out rate described and acceptable? The number of participants who were included in the study but did not complete the observation period or were not included in the analysis must be described and reasons given. If the percentage of withdrawals and drop-outs does not exceed $20 \%$ for short-term follow-up and 30\% for long-term follow-up and does not lead to substantial bias a 'yes' is scored. (N.B. these percentages are arbitrary, not supported by literature).

7. Were all randomised participants analysed in the group to which they were allocated? All randomised patients are reported/ analysed in the group they were allocated to by randomisation for the most important moments of effect measurement (minus missing values) irrespective of non-compliance and co-interventions.

8. Are reports of the study free of suggestion of selective outcome reporting? In order to receive a 'yes', the review author determines if all the results from all pre-specified outcomes have been adequately reported in the published report of the trial. This information is either obtained by comparing the protocol and the report, or in the absence of the protocol, assessing that the published report includes enough information to make this judgment.

Other sources of potential bias:

9. Were the groups similar at baseline regarding the most important prognostic indicators? In order to receive a "yes", groups have to be similar at baseline regarding demographic factors, duration and severity of complaints, percentage of patients with neurological symptoms, and value of main outcome measure(s).

10. Were co-interventions avoided or similar? This item should be scored "yes" if there were no co-interventions or they were similar between the index and control groups.

11. Was the compliance acceptable in all groups? The reviewer determines if the compliance with the interventions is acceptable, based on the reported intensity, duration, number and frequency of sessions for both the index intervention and control intervention(s). For example, physiotherapy treatment is usually administered over several sessions; therefore it is necessary to assess how many sessions each patient attended. For single-session interventions (for ex: surgery), this item is irrelevant.

12. Was the timing of the outcome assessment similar in all groups? Timing of outcome assessment should be identical for all intervention groups and for all important outcome assessments.

Single or double-level anterior interbody fusion techniques for cervical degenerative disc disease (Review) 


\section{Appendix 2. Assessment of Clinial Relevance}

Based on the data provided, can you determine if the results will be clinically relevant?

1. Patient description: Are the patients described in detail so that you can decide whether they are comparable to those that you see in your practice?

2. Intervention description: Are the interventions and treatment settings described well enough so that you can provide the same for your patients?

3. Outcome measures: Were all clinically relevant outcomes measured and reported?

4. Effect size: Is the size of the effect clinically important?

5. Benefits/Harms: Are the likely treatment benefits worth the potential harms?

\section{Appendix 3. Search Strategies}

\section{MEDLINE}

1 randomized controlled trial.pt.

2 controlled clinical trial.pt.

3 randomized.ab.

4 placebo.ab,ti.

5 drug therapy.fs.

6 randomly.ab,ti.

7 trial.ab,ti.

8 groups.ab,ti.

9 or/ $1-8$

10 (animals not (humans and animals)).sh.

119 not 10

12 exp Cervical Vertebrae/

13 cervical.mp.

14 degenerative.mp.

15 or/ $12-13$

16 fusion.mp.

17 exp Spinal Fusion/

18 interbody.mp.

19 Spondylodes*.mp.

20 or/16-19

$21 \quad 11$ and 20 and 15

22 limit 21 to $\mathrm{yr}=$ "2004-2009"

\section{EMBASE}

1 Clinical Article/

2 exp Clinical Study/

3 Clinical Trial/

4 Controlled Study/

5 Randomized Controlled Trial/

6 Major Clinical Study/

7 Double Blind Procedure/

8 Multicenter Study/

9 Single Blind Procedure/

10 Phase 3 Clinical Trial/

11 Phase 4 Clinical Trial/

12 crossover procedure/

13 placebo/

14 or/1-13

15 allocat\$.mp.

16 assign\$.mp. 
17 blind\$.mp.

18 (clinic\$ adj25 (study or trial)).mp.

19 compar\$.mp.

20 control\$.mp.

21 cross?over.mp.

22 factorial\$.mp.

23 follow?up.mp.

24 placebo\$.mp.

25 prospectiv\$.mp.

26 random $\$ . m p$.

27 ((singl\$ or doubl\$ or trebl\$ or tripl\$) adj25 (blind\$ or mask\$)).mp.

28 trial.mp.

29 (versus or vs).mp.

30 or/15-29

$31 \quad 14$ and 30

32 human/

33 Nonhuman/

34 exp ANIMAL/

35 Animal Experiment/

3633 or 34 or 35

3732 not 36

3831 not 36

3937 and 38

4038 or 39

41 exp Cervical Spine/

42 cervical.mp.

43 degenerative.mp.

44 or/41-43

45 fusion.mp.

46 exp Spine Fusion/

47 interbody.mp.

48 Spondylodes*.mp.

49 or $/ 45-48$

5049 and 40 and 44

51 limit 50 to $y r=$ "2004 - 2009"

CENTRAL

$\# 1$ (cervical)

\#2 MeSH descriptor Cervical Vertebrae explode all trees

\#3 degenerative

\#4 (\#1 OR \#2 OR \#3)

\#5 (fusion)

\#6 MeSH descriptor Spinal Fusion explode all trees

\#7 (Interbody)

$\# 8$ (Spondylodesis) or (Spondylodeses)

\#9 (\#5 OR \#6 OR \#7 OR \#8)

\#10 (\#4 AND \#9)

\#11 (\#10), from 2004 to 2009

BIOSIS

\#10 \#9 Timespan=2004-2009

\# 9 \#8 AND \#5

\# 8 \#7 OR \#6

\# 7 Topic $=($ random* $)$ OR Topic $=($ clinical trial $)$ OR Topic $=($ controlled trial $)$ OR Topic $=($ prospective* $)$

\# 6 Topic=(human) NOT Topic=(animal) 
\# 5 \#4 AND \#3

\# 4 Topic=(fusion) OR Topic=(spinal) OR Topic=(interbody) OR Topic=(Spondylodes $*)$

\# 3 \#2 OR\#1

\# 2 Topic=(degenerative disc) OR Topic=(degenerative disk $)$

\# 1 Topic=(cervical vertebrae)

\section{Appendix 4. Methods from The Cochrane Library 2004, issue 4 version of review}

\section{Search methods for identification of studies}

We electronically searched the most common databases:

- the Cochrane Central Register of Controlled Trials (CENTRAL) (The Cochrane Library Issue 1, 2004)

- MEDLINE (Through PubMed; 1966 to February 2004)

- EMBASE (Ovid online; 1980 to 2004 week 11)

- Current Contents (1996 to February 2004)

The search strings are given in Table 2. The strings in the second column are used and connected with OR within the cells, and with AND between the cells. The search strategy was adapted for the different databases. We made no restrictions on language or date of publication. We screened the references of the included studies, and with citation tracking, we screened references from the articles that cited the included articles.

\section{Data collection and analysis}

One author (WJ) conducted the literature search and retrieved the references to be evaluated. Two authors (WJ, PW) independently selected the trials to be included in the review and met to reach consensus. When consensus could not be reached, a third author (PA) was consulted to resolve the disagreement. The methodological quality of the trials was assessed independently by two authors (WJ, PW), with the van Tulder checklist (van Tulder 2003), who again met to reach consensus. As before, if consensus could not be reached, a third author (PA) was consulted to resolve the disagreement. Details of randomisation, blinding and exclusions from the analyses were recorded. Data were extracted and entered into RevMan 4.2.3 by one author (WJ) and checked by another author (PW).

Statistical analyses were conducted using Review Manager (RevMan) software 4.2.3. Publications were managed with the aid of Reference Manager ${ }^{\circledR}$. In addition, relevant information was recorded pertaining to database source, reason for exclusion and consensus of authors.

\section{Selection}

Articles were selected in two steps. In the first step, articles were excluded when it was apparent from either the title or abstract that the study did not meet the following criteria:

- The study was a randomised controlled trial.

- The interventions evaluated in the trials were comparisons of different techniques for anterior cervical interbody fusion

- The indication for the patients to receive the intervention was chronic (longer than 12 weeks) degenerative disc disease of the cervical spine

The outcome parameters in the studies were clinical, functional, or radiological measures. The minimal length of follow-up was six months.

In the second step, articles were excluded when it was apparent from a quick scan of the full text of the article that it failed to meet the same inclusion criteria. When the same population was described in more than one study, all studies were used, but only the most informative was used as the primary reference. The reason for exclusion was documented for each reference.

\section{Methodological quality assessment}

With the aid of a checklist, articles that met all the inclusion criteria were evaluated on meeting methodological requirements and objectives. We used the criteria recommended by the Back Group (van Tulder 2003) and. We regrouped these criteria into risk of bias (Table 3), external validity, and data presentation and statistical analysis (Table 4). Each item was scored good $(+)$, questionable $(+/-$ 
), poor (-), unsure (?), or 'not applicable'. We added a question on group and subgroup homogeneity, because heterogeneity is often encountered and accounts for the lack of power seen in orthopedic surgical trials. We also added a question on the description and validity of the statistical analyses used.

Risk of bias was assessed by considering randomisation, blinding, proper assessments and appropriateness of outcome measures, and comparability of groups. Randomisation with envelopes was allowed, but not date of admission, birth date, alternating schemes, or other comparable techniques. When studies used these techniques, it was regarded as a concurrently controlled trial and analysed as such. If in doubt, the decision was made on the information provided by the authors. Blinding of surgeon cannot usually be achieved in orthopedic surgery, so this is generally not met. Prognostic factors considered were: one or two-level surgery, clinical diagnosis (radiculopathy, radiculomyelopathy, herniated disc), and treatments applied. Loss to follow-up was graded as 'good' if it was less than $10 \%$, 'questionable' if less than $20 \%$ and 'poor' if greater than $20 \%$.

External validity was assessed by considering the completeness of the description of selection criteria, the treatment methods used, and the timing of follow-up. Short-term follow-up was considered to be follow-up that was shorter than five years.

Data presentation and statistical analyses were rated according to the availability of data describing the sizes of the groups and/ or subgroups, means, proportions, or other relevant point estimates and their precision. When heterogeneity of the intervention groups was observed, data (point estimates and precision) were required for the subgroups identified. In addition, the description and appropriateness of the statistical methods were rated.

The final judgement on the quality of the studies was based on a pre-set cut-off point. We decided that internal validity was the primary indicator for the quality of a study. When the evaluation of internal validity suggested a low potential for bias, the study was considered a high quality study. Minimal requirements were a concealed allocation procedure, drop out of less than $20 \%$, and homogeneous (sub) groups.

The final judgement on the strength of the evidence on each comparison was based on the Back Group's recommendations on Levels of Evidence (van Tulder 2003):

- Strong - consistent findings among multiple high quality RCTs

- Moderate - consistent findings among multiple low quality RCTs and/or one high quality RCT

- Limited - one low quality RCT

- Conflicting - inconsistent findings among multiple RCTs

- No evidence from trials - no RCTs

The potential to pool results was dependent on the comparability of the individual studies, i.e. identical treatments and outcome measures were used, sufficient detail was given to describe the selection criteria and other external validity criteria.

\section{Analysis}

For dichotomous outcomes, we calculated relative risks (RR). For continuous outcomes, we calculated a weighted mean difference (WMD). If sufficient data were available, subgroup analyses were planned to assess the effects of age, gender, disease severity, one or twolevel procedures, and length of follow-up time on the outcomes. Sensitivity analyses were planned to assess the effect of methodological quality (high or low) on outcomes. The use of a funnel plot was planned to identify publication bias. Heterogeneity was tested with a Q-test. When heterogeneity existed, post-hoc subgroup analyses and sensitivity analyses were planned to explore the reason for heterogeneity.

\section{FEE D B A C K}




\section{from Ronald Bartels, MD PhD, Nov 2004}

\section{Summary}

With great interest we've read the excellent review of Jacobs et al.(5). Although we agree with the conclusions, we want to address some points:

1) the results of a study by Barlocher were excluded, because they were presented in a Conference Proceeding. However, in 2002 they were also published in Neurosurgical Focus(2), an official peer - reviewed journal. Therefore, it is not correct to exclude the study from this review.

2) Neither is the study by de la Torre et al.(3) mentioned. Although only an abstract of a presentation at a meeting is provided, the reviewers should have attempted to contact the authors to get the original data. This procedure is also advocated in the Cochrane Handbook 4.1.

3) Most articles comparing cervical discectomy with and without fusion used Odom's criteria for assessing outcome. Some authors did not explicitly mention that they used Odom's criteria, whereas it is perfectly clear from the description. A common estimated outcome can be calculated using a larger number of studies. In this way, the articles from Bärlocher et al., van de Bent et al., Abd-Alrahman et al., Martins, Rosenørn et al., and Savolainen et al.(1;2;6-9), could be used to estimate a common odds ratio. If good (including excellent) is used for clinical outcome versus the rest (fair, poor), the estimated common odds ratio (Mantel-Haenszel) is 0,89 with a 95\% CL of 0.60 to 1.32 comparing non - fusion with fusion. The data of the study of Dowd(4) were not included, since follow - up was only 1 day! However, this calculation does confirm, that there does not exist any difference in clinical outcome between patients treated by cervical anterior discectomy with or without fusion.

4) The conclusion of the reviewers is correct. However, it could be formulated more explicit. Since the complication rate is higher with fusion with autologous material or more expensive in case of the use of alternatives to autologous bone, fusion should offer at least minimal advantages on the long term. These are only theoretical. Therefore, we would suggest that based on the results of this review hard evidence to perform a fusion after cervical discectomy does not exist. This has great impact since many studies are ongoing comparing arthroplasty and fusion (as the golden (?) standard).

Finally, we want to congratulate the authors with their major effort and results.

Sincerely,

R.H.M.A. Bartels, M.D., Ph.D.(1)

Gert Jan van der Wilt, M.D., Ph.D.(2)

University Medical Center St. Radboud

R. Postlaan 4

$6500 \mathrm{HB}$ Nijmegen

The Netherlands

(1)Department of Neurosurgery; (2) Medical Technology Assessment

References

1. Abd-Alrahman N, Dokmak AS, and Abou-Madawi A: Anterior cervical discectomy (ACD) versus anterior cervical fusion (ACF), clinical and radiological outcome study. Acta Neurochir (Wien ) 141:1089-1092, 1999.

2. Bärlocher CB, Barth A, Krauss JK, Binggeli R, and Seiler RW: Comparative evaluation of microdiscectomy only, autograft fusion, polymethylacrylate interposition, and threaded titanium cage fusion for treatment of single-level cervical disc disease: a prospective randomized study in 125 patients. Neurosurg Focus 12 January:1-12, 2002.

3. de la Torre M, Martinez-Quinones JV, Isla A, Argüello C, Bendala A, Casado J, and Blazquez MG: Anterior cervical diskectomy with and without bone grafting. Multicentric comparative study. J Bone Joint Surg Br 77B (Suppl I):24, 1995.

4. Dowd GC and Wirth FP: Anterior cervical discectomy: is fusion necessary? J Neurosurg 90:8-12, 1999.

5. Jacobs WCH, Anderson PG, Limbeek J, and Pavlov P: Single or double-level anterior interbody fusion techniques for cervical degenerative disc disease. The Cochrane Database of Systematic Reviews 2004 (3) Art. No.: CD004958. DOI: 10.1002/14651858.CD004958. 6. Martins AN: Anterior cervical discectomy with and without interbody bone graft. J Neurosurg 44:290-295, 1976.

7. Rosenorn J, Bech Hansen E, and Rosenorn M-A: Anterior cervical discectomy with and without fusion. A prospective study. J Neurosurg 59:252-255, 1983.

8. Savolainen S, Rinne J, and Hernesniemi J: A prospective randomized study of anterior single-level cervical disc operations with longterm follow-up: surgical fusion is unnecessary. Neurosurgery 43:51-55, 1998.

9. van den Bent MJ, Oosting J, Wouda EJ, van Acker EH, Ansink BJ, and Braakman R: Anterior cervical discectomy with or without fusion with acrylate. A randomized trial. Spine 21:834-839, 1996.

Single or double-level anterior interbody fusion techniques for cervical degenerative disc disease (Review)

Copyright (C) 201 I The Cochrane Collaboration. Published by John Wiley \& Sons, Ltd. 


\section{Reply}

Many thanks for your interest in our review and well thought criticism.

The study results by Barlocher et al were not included in the review because it was not found in our search in the databases as a peer reviewed article. It was also not referenced by the other trials published after 2002; Baskin et al and McConnel et al. We are grateful for pointing to this additional study and it will of course be included in the future update. The search strategy remains a potential source of bias in any systematic review, which needs careful attention. Possible solutions could be to contact authors of conference proceedings to ask for (pending) publications and to hand search more journal contents not included in Medline and other databases.

The study by de la Torre et al was not included because including conference proceedings and contacting authors for original data was not in the protocol for the review. The authors are right in pointing to the need to contact authors for original data, but this requires additional effort, which we hope we can address in the next update.

Regarding the third point: we feel that the studies mentioned cannot be combined in a meta-analysis on the outcome parameter suggested because the definition of the score differs among the studies. Savolainen only uses three categories where the others use four. Rosenorn relies heavily on occupation where others do less. The difference between the definition between fair and good (the critical definition when good is the threshold) is not uniquely defined. We present the definitions used by the studies below. We therefore suggest strongly to the orthopedic society to come to more agreement on the outcome parameters to be used in clinical evaluations. An example could be taken from the OMERACT initiative used for rheumatoid arthritis research.

Finally, our approach was to present the evidence and draw conclusions to the extent of explicitness we feel funded by the studies found. We feel that we have not yet enough power to show equivalence, certainly as we did not perform meta-analysis on the selected studies with regard to complications. None of the studies aimed at identifying non-inferiority of discectomy. We agree with the authors that there is no established gold standard for cervical degenerative disc disease and this is supported by our results.

We hope continuously to improve our review methodology and appreciate very much these constructive remarks.

\section{Contributors}

1st author, Wilco Jacobs, MD

\section{WHAT'S NEW}

Last assessed as up-to-date: 14 November 2009.

\begin{tabular}{l|l|l}
\hline Date & Event & Description \\
\hline 14 February 2011 & Amended & corrected typo in Plain Language Summary; 'patents' to 'patients' \\
\hline
\end{tabular}

\section{H I S T O R Y}

Protocol first published: Issue 4, 2004

Review first published: Issue 4, 2004

\begin{tabular}{lll}
\hline Date & Event & Description \\
\hline 23 June 2010 & New search has been performed & Updated review with 19 new studies
\end{tabular}




\begin{tabular}{l|l|l} 
23 June 2010 & New citation required and conclusions have changed & $\begin{array}{l}\text { conclusions changed due to more studies and updated } \\
\text { methodology }\end{array}$ \\
\hline 17 November 2004 & Feedback has been incorporated & $\begin{array}{l}\text { Feedback added: 06/11/04 } \\
\text { Response to feedback added: 17/11/04 } \\
\text { See Feeback section. }\end{array}$ \\
\hline 28 February 2004 & New search has been performed & $\begin{array}{l}\text { This review updates the systematic review published } \\
\text { in 2001: } \\
\text { van Limbeek J, Jacobs WC, Anderson PG, Pavlov } \\
\text { PW. A systematic literature review to identify the best } \\
\text { method for a single level anterior cervical interbody } \\
\text { fusion. Eur Spine J 2000; 9(2): 129-36. }\end{array}$ \\
\hline $\begin{array}{l}\text { This review includes 14 studies, six more than in the } \\
\text { 2001 review. One additional study was identified, but } \\
\text { the authors are still waiting for the full text of the arti- } \\
\text { cle. If it meets the inclusion criteria, it will be included } \\
\text { in the next update }\end{array}$ \\
\hline
\end{tabular}

\section{CONTRIBUTIONSOFAUTHORS}

Wilco Jacobs (WJ): Protocol, Trial selection, Risk of bias assessments, Data extraction, Report, Coordination Paul Willems (PW): Protocol, Trial selection, Risk of bias assessment, Data extraction, Draft review

Patricia Anderson (PA): Third reviewer consultation, Draft review

Jacques van Limbeek (JvL): Consultant

Ronald Bartels (RB): Clinical interpretation, Draft review

Paul Pavlov (PP): Clinical interpretation, Draft review

Cumhur Oner (CO): Draft review

\section{DECLARATIONS OF INTEREST}

none 


\section{SOURCES OF SUPPORT}

\section{Internal sources}

- Sint Maartenskliniek Nijmegen, Netherlands.

LUMC provided for time and material resources.

- Leiden university Medical Center, Netherlands.

LUMC provided for time and material resources.

\section{External sources}

- No sources of support supplied

\section{DIFFERENCES BETWEEN PROTOCOLANDREVIEW}

This updated review has some changes from the initial protocol and review.

- The methodological quality evaluation was simplified and adheres to The Cochrane Collaboration and Cochrane Back Review Group's new recommendations to use Risk of Bias tables. Tables with in- and external quality have been replaced by these tables. This standard of including text for Risk of Bias assessment was new, and only added for the newly included trials. This was also the case with the first question of the clinical relevance assessment.

- We adopted the GRADE approach to grade the quality of the evidence.

- Definition of complications were added after selection of studies, but before data extraction.

\section{NDEX TERMS}

\section{Medical Subject Headings (MeSH)}

*Intervertebral Disc [surgery]; Cervical Vertebrae [* surgery]; Diskectomy; Ilium [transplantation]; Intervertebral Disc Displacement [surgery]; Randomized Controlled Trials as Topic; Spinal Fusion [ ${ }^{*}$ methods]; Spondylosis [ ${ }^{*}$ surgery]

\section{MeSH check words}

Humans 